\title{
2015
}

\section{THE CONTEMPORARY ISSUES AND SUPREME COURT}

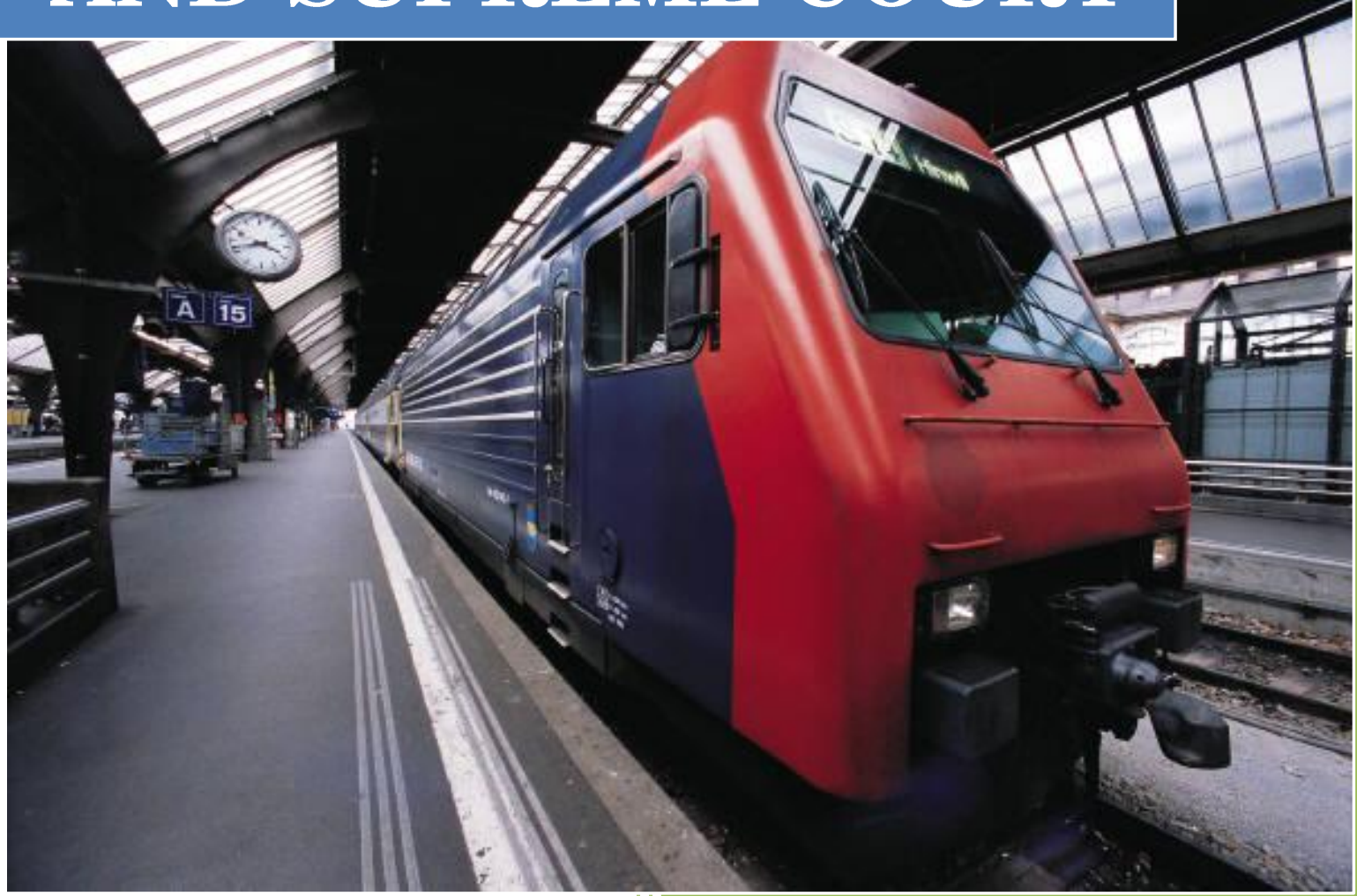

KIYOUNG KIM, PROFESSOR OF LAW AND PUBBLIC POLICY

THE LEGAL RESEARCH

INSTITUE, COLLEGE OF LAW, CHOSUN UNIVERSITY

2015-06-26 


\section{The Judicial System, Strengths and Limitations}

\section{Marbury v. Madison, a Landmark Decision}

The impact of Marbury v. Madison is consequential, which is beyond that specific controversy, i.e., a delivery of Commission to several dozens of new appointees by new president (Marbury v. Madison, 1803). Several aspects can be highlighted touching on its meanings and implications.

A first insight arises from the relationship between the politics and law. The case is a landmark decision which places the law in any hierarchy of control on the politics. Generally, the democracy is practiced with the collegiate body. That is plainly self-evident if we trace the Curia Regis or primitive form of parliament, such as Etats Generaux. With respect to the idea of John Locke, the power of Monarch has several attributes, i.e., legislative, prerogative, power to federate and so, but no specific mention of judicial power. The orthodox of European states, such as England, Germany and France, would normally be classed as the parliamentary system of government, which means that a political will, as consonant with the principle of consent, resolution or majority rule, would supervene any other expression of nation. The state legislatures in the colonial period may well be considered as a paragon of this understanding. The maxim, "new laws always alter a previous arrangement" generally represents this thought that a parliament is ultimate forum for the national will around the early of this nation. This "later time in rule" is sacred in terms of political theory and convenience of rule which is a retrenched vehicle to exploit the interest of colonial land. The skepticism, "distrust of politics," was spawned because of abusive state legislatures while the idea and beliefs of higher law concept in earlier common law thinkers would merely be a haunt not settled institutionally. The inauguration of Constitution provides as epochal against the parliamentary sovereignty, but with no express language of judicial review. It is the highest law of nation according to the clause of federal supremacy, but an equal rank in terms of the plain text of Constitution, with the federal laws and international treaties. Hence, it is dubious whether the Constitutional justice could legitimately preempt the unconstitutional act as a matter of theory and practice. These ambiguities was resolved by the judicial invention in Marbury v. Madison, but still is being debated in terms of its antimajoritarian character (Douglas, 2003; 1803).

Second, the case brought the rule of law ideals to be settled concretely and institutionally for the nation as well as many new born republics of world. The rule of law is an indispensable ingredient of modern democratic form of government, which ensures the liberty and equal protection as well as provides a legal stability and predictability. The arbitrary exercise of governmental power can be prevented from and checked by the judicial review. The rule of law ideal requires a congressional rule on one hand, while the kind of demagogue has to be ruled out as we recall upon the Platonic Republic. If the majority rule is absolute and plenary without a check, it possibly could be any worst form of government as in the Plato's case concerning democracy. The Constitution and judicial forum of selected minds could provide a space of deliberation to check and balance against an abusive majority. In progress over this judicial revolution, the concepts or practice of common law court in history certainly provided a backdrop for Marbury v. Madison, which includes the higher law concept, inalienable rights, stare decisis, judge-made law views, habeas corpus and recognition of natural law (Schauer, 2006; Vile \& Menez, 2010; 1803). The other practical force to foster this decision should be found in the ethos and political atmosphere in the 
newly independent nation. The new Constitution enabled to bring a popular democracy and was based on the second nature of wealthier class other than the nobility of mainland Europe. A plutocracy and commercial bourgeois than the agricultural potent would be the main pillar of new Republic who eagerly pursued a limited government. They preferred "people" than "ruling nobility" and the power of government should be checked on balance, which should not infringe with their new wealth and economic interests. They prefer the Constitution than normal legislation, which is more "humanistic and palpable, fundamental as well as sacred, and must be borne with the weightier process of creation or amendment and impression. It is the kind of replacement for the "Plato's benevolent King," which is, however, extant of documentary form and written language. The constitutional amendment is harder than that of congressional acts and theorists would argue that some crux of principles could not be repealed even with the constitutional process of amendment. In this sense, the "law and politics" would combine to impact on the new institution of judicial review, a crucial element of the rule of law and now considered as indispensable in the modern form of democratic rule.

Marbury v. Madison and the system of judicial review created from the case are considered essential in maintaining the federal system of government (Douglas, 2003; Schauer, 2006; Vile \& Menez, 2010; 1803). The Supreme Court is a unique judicial organ to exercise the whole jurisdiction of nation, and generally seen to enjoy a "final say of constitutional meanings." The relationship in terms of structure and function and between the federal and statement government could be finally arbitrated by the organ as well as in system and by predicable case laws. The constitutional history of nation plainly convinces this view that the Supreme Court had rendered a standard and principle involving the important and controversial national agendas of federal system. The lesson on the role of judicial organ toward the stable federal system also can partially replicate in the progress of European integration. The European court of Justice may play to support the unity and commonality of European politics, rather limited in scope and nature than the US, in which the case laws and judicial power could not only be controlling, but also fluctuate on prospect and regression.

The scope of impact is serious that the UN is now framed on the universal recognition of human rights, which are a prime strand to provide a cause of action. The import of judicial review as an apparatus of constitutional democracy is widely accepted by the global jurisdictions although we may see some institutional variations concerning which institution finally would be responsible to exercise that power. While a primitive form of constitutional review may be alleged to practice in the $16^{\text {th }}$ Germany, many European states and international tribunals of human rights would resemble the idea and spirit of US judicial review to defend the basic human rights.

\section{One Supreme Court Decision}

In February, 2015, the Constitutional Court of Korea invalidated the adultery statute, which has history-long been believed as criminally culpable (KCC, 2015).

The court opinion split that seven justices agreed to render it unconstitutional with two dissenting opinions. The statute under review is the Korean Criminal Code Art. 241, which provides, (i) the married person shall be imprisoned within two years, who committed adultery; (ii) his or her partner shall also be treated as same (iii) the punishment shall be conditioned on the complaint of spouse;(iv) in case where the spouse condoned or induced 
the adultery, he or she cannot file a legally effective complaint." The constitutional complaint was initiated by the criminal judge, who was responsible to adjudicate on the trial. In view of comparative purpose, the Korean system differs that only judge can petition a constitutional review in specific conditions. The effect of unconstitutional ruling is "more direct, immediate and comprehensive" to invalidate the act under review with the general and abstract consequence (2015).

The gist of majority opinion is as follows; (i) the statute under review was enacted to protect the public morality of sex and to ensure a social system of modern family against the bigamy (ii) the statute infringes with the right of self-determination on sexual relationship and right of privacy (iii) the public consensus on the culpability of adultery can no longer be convincing (iv) the modern theory of criminal law generally supports that the criminal muscle of nation shall not stretch into the area of privacy in case where the social harm is not great and no appreciable damage of any specific quality is present $(v)$ global jurisdictions generally agree on its abolition (iii) the effect of prevention and deterrence turns less significant in the statistics charted about the case proportions and popular recognition of its culpability (vi) protection of damaged spouse can be more effectively redressed by the civil damages and judicial proceedings of divorce (vii) the statute is misused to the interest of culprit, who utilizes as a basis of divorce and menaces the less culpable and middle-age females (viii) balancing test between the public interest to maintain the adultery as a crime and harms from non-intervention also lends the support that the statute excessively restricts a sexual freedom and self-determination, as well as the right to privacy (2015).

Two justices of dissenting opinion argued (i) the adultery is viewed to infringe with the right of other and as an issue of public order, neither merely moral nor ethical (ii) its abolition will degrade the sexual morals of public and dismantles a prevailing belief of its culpability (iii) it intrudes the traditional family virtue and can accelerate the destruction of familial relations (iv) legislative findings to regulate the adultery as a crime is neither an arbitrary nor excessive measure to intervene the domestic relations.

The majority and dissenting opinions along with one concurring opinion raised other several grounds to support their position, which is not detailed here. For example, the majority opinion pointed out that the scope of criminal actors is overbroad and the only sort of punishment, namely imprisonment as most heavy in quality, would unreasonably restrict the discretion of judges (2015). The dissenting judges countered that the term of imprisonment is not lengthy. They also opined that the child welfare and socially congruent family relations impel to sustain the legislative intent.

\section{A Thought on the Impact}

The decision of Marbury v. Madison is significant to address the ways of modern democratic government (Marbury v. Madison, 1803).

First, the constitutional review in Korea would educate the people and policy makers by illuminating the constitutional meanings.

Second, the role of constitutional court would safeguard the basic rights of people from the majority rule, which can possibly disparage the humanity and society (PBS 1, 2015). 
Third, the constitutional court functions to protect a minority interest, which shall be viewed as fundamental as well as insular or discrete in cases. The defeated political group can find a haven, which would possibly be discriminated by the ruling party. In this sense, the constitutional review (i) has a virtue on humanistic ground, and (ii) is the kind of justice issue than political one, and (iii) deals on the fundamental course through thoughts and deliberation, and (iv) is based on case or controversy other than creative and leading (PBS 2, 2015).

Fourth, the constitutional review provides a check and balance mechanism to prevent from the arbitrariness of government.

Fifth, the constitutional review leads to the "workable government" and complies with the "concept of lifetime learning." The scientific evidence and the kinds of practice, amicus curiae, may have a bearing in this respect (Kim, 2014).

\section{Strengths of Supreme Court}

The strengths of Supreme Court in policy making may arise in aspects and qualities.

The judicial independence would come into mind at first instance. The Supreme Court justices enjoy a lifetime tenure and are constitutionally ensured of their salary and status. It severs their business from the political influence, and creates their due insulation in deciding important national agendas. A logrolling or pressure from the public normally is less present that they can deliberate on the professional knowledge and conscience as envisaged in the Plato's ideal. The Constitution and federal laws only could bind their course of deals with the specific case (Douglas, 2003). Because of this nature as lodged with the role and responsibility of theirs, the public concerns and would be attentive of their political or philosophical beliefs, educational and social background, as well as their personal and career path since their impact is highly consequential. Although some research findings reveal that the Supreme Court justices carry their constitutional duty massively on the normative disposition than a political and social virtue or tenet, the fact that the post requires a top policy making role, many non-legal elements on the personality and intelligence are the kind of popular attraction. Generally the public is concerned between the conservative and liberal or progressive justices. Scholars are also interested in their political affiliation of President who nominates them for the position, which generally finds a strong ties and common ethos with the party of nominating president. This may be received to imbrue with the principle of judicial independence, but may positively operate to save the judiciary from their own circle of professional cadres. This interchange can work to reinforce the Supreme Court from any mere of judicial sanctuary to the bulwark of popular democracy and may assuage an attack from its anti-majoritarian character of judicial review (PBS 2, 2006). As Bickel argued, the judiciary can well be conceived as one of "least dangerous branch" since they enjoy a leisure, insulation from the political influence and scholarly way of dealings (Bickel, 1986).

The Supreme Court is any more than adequate forum to debate on public policy since the judicial theory espouses firmly the doctrine of stare decisis (Schauer, 2006). It provides a legal certainty, stability and predictability that are viewed as essential in creating and implementing a public policy. That deserves a focal attention since the public administration basically is grounded on the "standard of conduct." Without this strand, the policy addressees, 
often the citizens and public agency themselves, would have to get lost from inconsistencies, contingencies and uncertain or ambiguous laws and regulations. For example, we may experience the art of terms frequented in the judicial review, such as "overbroad and overarching," which reveals the nature of judicial business. This aspect is intertwined with the scholarly way of dealings as Bickel elicited, as well as the judicial style of common law system. The common law judges, perhaps in contrast with the kind of French style, would never hesitate to write a lengthy opinion, which begins with the details of fact through making an analogy and distinguishing as well as pages of reasoning. This would create a basis of law, which binds the subsequent court and this specificity contributes to more a suited standard of conduct found no elsewhere. In combination of stare decisis rule, the nature of common law court in dealing with their constitutional duty would strengthen its competence and suitability in making a public policy (Vile \& Menez, 2010). The lesson of Marbury v. Madison deserves a special mention since it filled a vacuum of law relating with the statutory basis of judicial review (1803). Often the courts are viewed to exercise an interpretive power against the abstract nature of constitution and statutes. An imperfection of statutory language is usual to bring a space that the Court plays a role. However, the vacuum of law is less usual, and the court judges, nevertheless, should apply any law to the specific dispute which poses a challenge as same with the Chief Justice. Since the common law judges recognize the case law as an intrinsic of law, the opinion of John Marshall is the kind of "foundational and judicial sanctification" to lay a profound impact on the modern constitutionalism (PBS 1, 2006). This development can be made a reality because of the common law tradition and stare decisis rule.

\section{Limitations of Supreme Court}

The limitations of Supreme Court lie in its judicial restraints or passive nature of role. Since their authority is grounded on the Constitution, the requirement, "case or controversy" termed in express language from Article III delimits its scope of intervention (Marbury $v$. Madison, 1803). While the Congress and Executive are (i) general, (ii) creative, and (iii) active to deal with the policy issues, the judiciary would not be of initiative to create the public policy. Otherwise and in the least, their initiative would be limited to create the house rule and a piecemeal autonomy or administration for their internal affairs. In comparative view, Korean judiciary would be empowered to plan on the budget of judiciary and file an official opinion of court for the legislative process on the subject matters of judicial branch. The "case or controversy" requirement would offer the constitutional ground for many doctrines invented by the judiciary, such as mootness, ripeness, standing or reviewability and so. The weaknesses on this trait would be related with a grievance of civil pressure group involving the environmental protection and other progressive national agendas. Most fundamentally, the passivity of judicial role only could dispose a negative decision against the illegal action of Congress and Executive. They are generally seen as void of power to positively command and order to provide, except for few sources of authority, such as injunctive relief.

One other limitation of Supreme Court would underlie a twilight area of public policy entangled between the political and normative qualities. The foreign policy and warfare issues are notorious for the retreat of judicial yardstick. We note that the President in the United States is a commander in chief as a matter of constitution. The war-making authority generally vests within the Congress, however. The conflict of authority readily happens since the war situation tends imminent and requires of confidentiality. The President 
and his aids prefer to respond with the war more strategically, which requires a tacit interaction possibly negating the constitutional authority of Congress. In some cases, the President may seize the steel industry to suppress the protest of labor union in an emergent need and in the end to preserve a war responsiveness as well as potential of national capabilities to build the arms. As we see, it is one of contentious issues around the legal circle whether the Bush administration acted on any normative ground of legitimacy when it pursued the Iraqi War. The presidential privileges and immunities are also one of ambiguous area of constitutional issues, and Nixon v. Clinton would be a popular source of review in understanding the delicacies and hardship of judicial enlightenment. Thankfully, however, there is an embedded rationale to distinguish justiceable issues from those of political question.

\section{Some Note from the Public Survey}

Since we are granted that the amendment of constitution requires interacting with an iron cloak, we may hint on the public poll involving the structure of government or society. The Figure 1 was from Gallop, which shows the confidence level of public institutions in US. Most stark in implications would be that the public confidence generally declined, yet at considerable rate. This implies that the society had transformed in depth to deserve any comment of paradigm change. The electronic mode of lives and post-modern view may not be mere of a hype that impacts the citizenry to distaste and to be alienated from the public institutions. It is worthy to note that the Supreme Court remains rather strong and consistent to interact with the trust of American public. The next Figure was from one British poll about the traditional professions socially reputable. The judges are placed at third above the clergyman, which implies the public highly favors judges as their intellectual or social companion. This is somewhat distinct from the tendency of American people while the religious institution topped in the US. As we know, England is one of religiously independent countries that proclaimed the National Church as early in the age of Henry VIII. They chose the public rather than religion in such early years, in which the lawyers are most approximate in terms of religious quality. The last Figure shows the Korean statistics that surveyed which institution is most trustworthy by the public. The military gained a first spot which is followed by judicial branch. The military confrontation with North Korea may factor at some extent, but the trust with their national army seems to be generally common notwithstanding jurisdictions. In three Figures, the political branches scored as less than median, which may statistically be implicating with the theme of "distrust of politics." From the British source, we may enchant that professors attained a high level of confidence, perhaps some of replacement from the classic religious influence along with court judges. As Bickel commented, the "scholarly way of dealings" will be one point of strength as practical ground and for the current structure of Constitution (1986). Then we can surmise if the public would support or like to be trusted with the "learned hands," of course, not a name of judge. The concept of "lifetime learning," especially in this e-age, seems a strand to echo with the public leaderships and officers, who prefer to gain a public trust.

- Figures Attached

\section{Figure 1}




\section{Confidence In Institutions}

(\% "Great Deal"/"Quite A Lot")

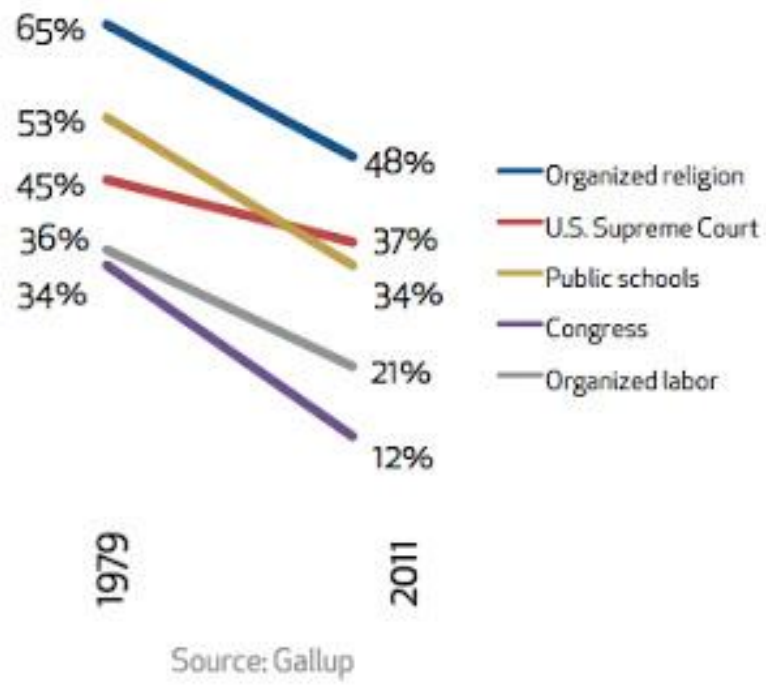

\section{Figure 2}

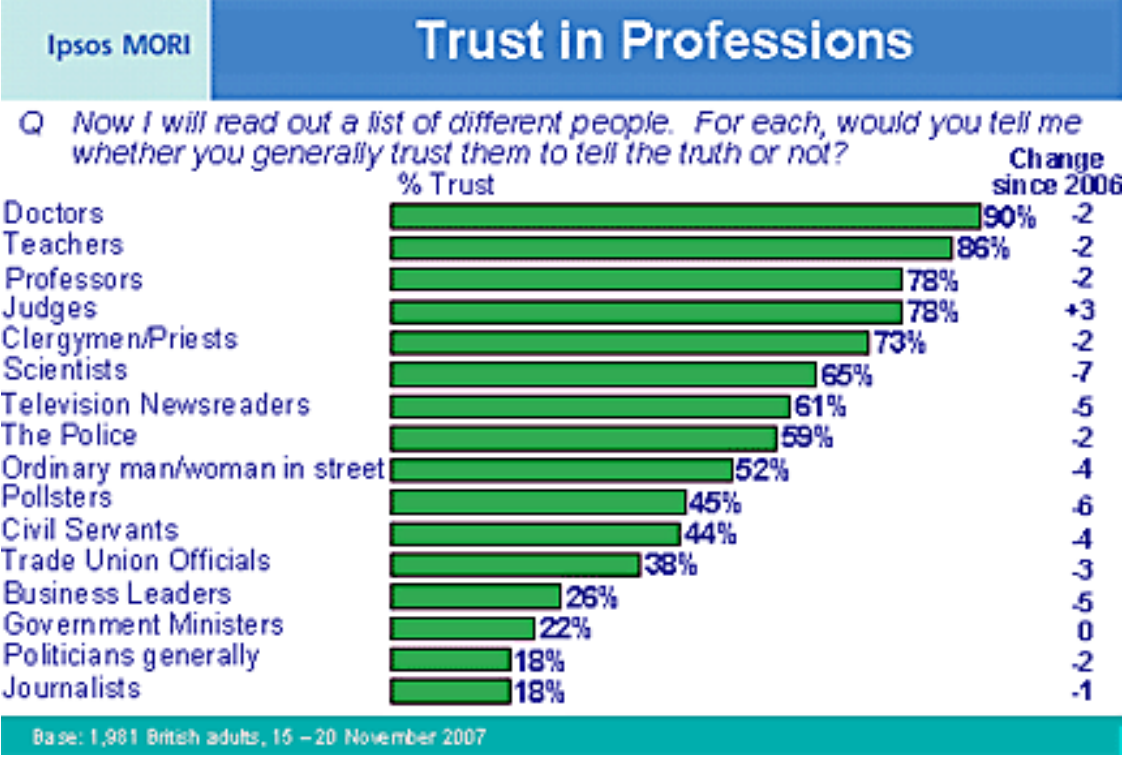

\section{Figure 3}




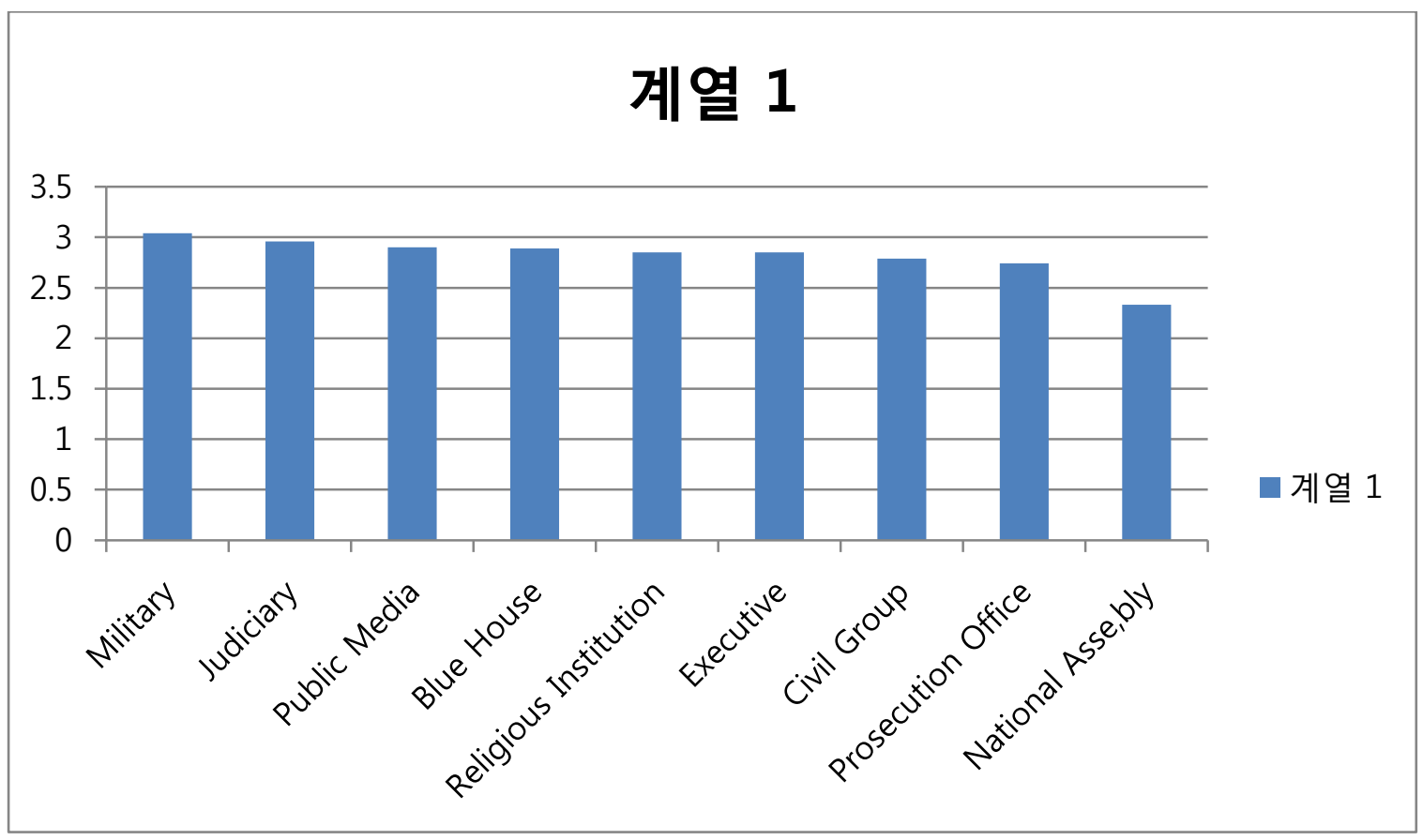




\section{Reference}

Bickel, A.M. (1986). The Least Dangerous Branch: The Supreme Court at the Bar of Politics. New Haven. CT: Yale University Press.

Douglas, D. (2003). Symposium article: The rhetorical uses of Marbury v. Madison: The emergence of a "great case." Wake Forest Law Review, 38(2), 375.

KCC, 2009 C-BA 17 (2015).

Kim, Kiyoung, The Separation of Powers Principle: Is it a Lynchpin or Pushpin for the Voyage of American Public? (August 1, 2014). International Journal of Advanced Research (2014), Volume 2, Issue 8, 887-895. Available at SSRN: http://ssrn.com/abstract $=2573560$

Marbury v. Madison, 5 U.S. 137 (1803).

PBS. (2006). Supreme Court Chief Justice John Roberts: On John Marshall and the establishment of judicial review. Retrieved Mar. 2, 2015 from http://www.pbs.org/wnet/supremecourt/bonus/john2.html.

PBS. (2006). Supreme Court Chief Justice John Roberts: On John Marshall's contribution to the American law and politics. Retrieved Mar. 2, 2015 from http://www.pbs.org/wnet/supremecourt/bonus/john1.html.

Schauer, F. (2006). The Supreme Court 2005 term: Foreword: The court's agenda-and the nation's. Harvard Law Review, 120(1), 5.

Vile, J. R., \& Menez, J. F. (2010). Essential Supreme Court decisions: Summaries of leading cases in U.S. constitutional law. Lanham, Md: Rowman \& Littlefield Publishers. 


\section{The Trait of Supreme Court}

\section{On the Role of Supreme Court: Judicial or Political?}

As expounded, we note that the views could be highlighted in perspectives. One view takes it as granted and morally demanded that the role of Supreme Court is essential to bring a social progress and constructs a social meaning of Constitution. This view, therefore, generally espouses a judicial activism while "the views of governments, law, and society largely hinge on how one interprets and defines the Constitution (Reinhardt, 1994)." The notion, hence, rejects the view that the Constitution is merely "a procedural charter" or "technical document allocating the power among governmental units," which possesses a limited purpose to structure and embed the federal power. It also would be skeptic if the Republicanism is plenary and always sweeping over any fundaments as antithetical. This tends to strengthen the argument of anti-majoritarian difficulties, a lawyerly way to shape the public policy as well as natural law concepts inviolable before the written charter of nation. The view finds many principled phrases, such as equal protection and due process, as a basis that the Courts could infuse their idea and philosophy in creating a public policy essentially intertwined with the protection of individual rights. Even the silence of Constitution provides a "working space" that the judicial deliberation on conscience and legal theory as prudent against the possibly mischievous, biased or oppressive political or policy decision, can author to realize the ideal and vision of social progress. The view may critique "Garcia's attack on the Great Justice William Brennan for inappropriately combining policymaking with judging" since the "Constitution is a living, growing document that has as its fundamental securing of a certain type of liberty for all Americans (1994)." The other view generally results in the judicial passivism that the Constitution may essentially be a document to create the federal union, so that (i) the normative deals, perhaps as championed of "plain language rule" or even clerical rule, are the intrinsic of judicial role (ii) the structure and distribution of governmental powers are a main concern of Constitution as the name implies in linguistic sense and in compliance with the public condition or needs of that document at the time of creation. Then it could be suspicious if the Court would actively work on the protection of individual rights since (i) the role is a matter of normal legislation or case law other than Constitution (ii) the responsibility to protect the individual rights would generally fall within the normal courts and not in the title of Constitution (iii) the judicial statement shall be strict with "judging" than "policy making" since the representation lacks or in the least, would meekly be hyped in analogy.

\section{On the Policy Making and Protection of Individual Rights}

While we have a thought between the policy making role and protection of individual rights, those may not be separable in the process of constitutional review. That is theoretically because (i) the judicial power is conditioned on the "case or controversy" requirement claiming any certain or judicially identifiable harms (ii) the constitutional review would be plenary in terms of the legal ground and irrelevant with the counts or arguments of counsel, meaning that the Justices may invoke the Articles of main text other than bill of rights as a ground of their opinion although the counsel would not bring to consider. That is perhaps because the traditional maxim would operate that "judges know the law and the fact should be from the jurists." In this context, the judges can posit many standards concerning who decide the public policy and on which ground they shall act in creating or implementing the public policies. Of course, it is also true if the courts could now entertain a very importance 
of individual rights in suggesting the desired way of policy making on the levels of government, say, federal, state and local (Pardo, 2005). Perhaps the original vision expected of judicial power might be limited to the first odd that the role of Courts would shrink like a clerk to announce the plain meaning on the federalism and distribution of governmental powers for the three branches. That would be one other way to clarify a sophisticated or even muddied controversy involved with the certainty of court role. Of course, other way is to structure the judicial power expressly in the Constitution, as well as on the basis of majority support, and may get facial to use the term "constitutional review" than "judicial review."

Nevertheless, we may admit that delicacies from the absence could be seen, in other light, to diversify the views and promote a constitutional culture from the insipidity or callousness of majority rule.

Therefore, we can hint if the earlier decisions of Supreme Court would involve a technical controversy often entangled with the structure and constitutional power of government (Vile \& Menez, 2010). It would be the kind of important concern whether the national bank could be taxed by the state government or if the writ of mandamus to oblige a delivery of commissions is permissible in terms of interplay among the branches. The earlier judges might be surprised if one witness can declare the constitutional meaning against and therefore, overrule the acts and statutes, such expression of political majorities. The traditional two-witness rule would have more implications if it could foreclose any betrayal of truths, but that never happened in the legislature to pass the rule of John Marshall. John Marshall might, in this case, would be the kind of witness to declare the constitutional order, human conscience and lawyerly conviction on the public matter.

Now that the bill of rights became incorporated shortly after the inauguration of Constitution, it imposes challenges of what these clauses would actually mean. It is not a state matter that perplexes the Justices if they would act like the lower courts, to order the civil damages or any public remedies to redress an individual harm. Comparatively in law, some countries, including Korea, had a system that the Constitutional Court would not interact with an individual on any legal basis, which exclusively is assigned with the power of state matters and interact with state agencies. For the judicial activists, the constitutional history of US is graceful to realize the flowering of constitutional culture by stepping into the area of individual rights and allows to elucidate what should be for the American public lives at the moment with the aggrieved parties (PBS, 2006). For example, Roe v. Wade would rescue a depraved pregnant woman with an allegedly mal-practice of state on one hand and would impact profoundly on the policy making about the abortion regulations and public system (1973).

\section{Strengths and Limitations}

While it is obvious as above briefed, the strengths of judicial role related with the individual rights generally stem from the first view, in which the Courts would be enthusiastic and engage in deep commitment illuminating on the desired social progress. The legal realism is a mainstream of legal intelligence in our land, in which the sociology of law as well as market theory of institutionalism would cultivate our system and institution. The Courts, as a final decision maker, could enlighten the path of American progress involving many sensitive public issues, from the protection of privacy right through the first amendment freedom on commercial speech, and segregation or desegregation of racial minorities within the public schools (Griswold v. Connecticut, 1965). 
This tradition could continue from the judicial style of common law jurists and flourished to interact with the sociological studies of law in $19^{\text {th }}$ Germany or critical theory in the early of last century (Glendon, Carozza, Picker, 2014). The Courts, under the auspice of institutional and political shield and as crossed over many global jurisdictions besides ours, could play both critically and authoritatively on the public agenda. It is institutionally possible since the constitutional democracy had hailed its way, and it is politically possible since they can enjoy a quasi-representation through the nomination or appointment by the President and normally with the congressional consent as well (2014). A protection of individual rights would create the kind of scaffold that the court could entertain as a theatre in networking the state or humanistic philosophy with the state intervention. As the humans and society are the main theme of intelligence besides the natural, medical or engineering science, there could we find a playground to elicit such principled, but mostly reticent document about the specifics and direction of nations.

The strengths will double given that the settings of judicial business are distinct from the lastly peeled persons, often called parties in the adversary system. They themselves inculcate the jurists, and their facts alleged often reflect the social or political contingencies of significant importance in our experience of constitutional history. The counsels would be a hybrid of investigator to be eclectic with the theory of laws and be a striving fact finder to support the case of his client, who also would well utilize an expert to evidence the dispute scientifically. A dialectic process would reinforce the issues of dispute as the kind of policy disagreement among various alternatives. It may be the kind of realistic lab dealing with the humans and society susceptible of public policy. Only with an extraordinary enthusiasm, faith and affectation of elected officials or bureaucrats, this kind of convivial situation would normally be present to unearth the truth which would be the basis of creating a public policy.

The limitations may arise from the generality of judicial business. The executive branch and committees of Congress would often be staffed with career professionals in its specific field. Through the education or career years, they often are any expert about their subject matters which perhaps might arouse them to murmur "the kind of stupid judges or sleeping queen," at their loss in the dispute. They may prefer the second vision that the judges should be a clerk or only the gate keeper to preserve the constitutional language as literal. They may be skeptic if the judges spell out their beliefs as in the case of Graglia, especially because it is in the name of rulings and with the cloak of supreme law in the land (Graglia, 1994). As Reinhardt viewed and as impressed from the clerical imagery of Rhine river jurists, it might be precise if one Kansas City has to "have a twenty-five acre nature area, a planetium, a model United Nations, and an Olympic-sized swimming pool, while other school districts in Missouri lack funds to buy books or maintain basic facilities (1994)." As said, the goodness and wisdom are essential in creating judicial policy, which seems crucial of multifarious effect on the society. Nevertheless, we also ponder if the climatic constitutional event of history had always been moral or at least if in support of the legitimacy from constitutional democracy. It might be hard to avoid our standard whether "the judicial activism has reliably served the advancement of liberal causes...than morals (1994)."

The second limitations in my thought would lie in its conservative quality of work process and narrow focus on the dispute. Their work frame crucially intertwined with the review of prior cases, what we call a precedent, hence, the kind of historical approach. It made the progress inefficient and lagged by lacking one time moment to overhaul the social evils schematically and preferably comprehensively. As seen, the frame has strengths to 
defend the legal stability and predictability on one hand, but dispassionate judges may less be seized with some rising public quest, i.e., the core of Republicanism and only testifiable from the political election. The 1960's civil rights act may be one example to bring a new paradigm of human rights recognition comprehensively, yet from a limited saying of Courts.

\section{Gideon v. Wainwright}

In purpose of this discussion post, I chose Gideon v. Wainwright and will explore the consequence that it impacts on the levels of government. The case was decided in 1963, and arose from the state criminal proceedings if he was convicted of noncapital felony that he had broken into and entered a poolroom with intent to commit a misdemeanor (Vile \& Menez, 2010). Through the development of case laws, it is generally deemed constitutionally required that the state has to provide the right to counsel for the indigents. Under the requirement, the State of Florida maintained a provision that the indigent defendants for felony should be afforded with a state-appointed counsel. Since Gideon was charged with non-felony, the criminal judges refused to appoint the counsel and Gideon appealed his conviction on the ground that he was deprived of constitutional guarantee for the assistance of counsel (2010). The Supreme Court ruled that the statute is unconstitutional to infringe with the Fourteenth Amendment right on fair trial. It opined that the right to counsel is essential and fundamental, and noted, "reason and reflection require us to recognize us to recognize that in our adversary system of criminal justice, any person haled into the court, who is too poor to hire a lawyer, cannot be assured a fair trial unless counsel is provided for him (2010)." The court also enunciated on the essential importance of right to counsel as a component of US legal system. The implications of this case provide a point of reflections in terms of individual right and public policy making.

\section{The Rule of Law and Due Process Rights}

As we note, the rule of law is an ideal we strive to pursue the public sphere of interaction between the state and subjects. This ideal requires most crucially that the due process of laws come into play involving a compulsory measure of state authority (Pardo, 2005). The due process of law perhaps would be the kind of interchangeable terms practically and vastly in administering the state role and responsibilities. The criminal institution also is traditionally pivoted on this concept and public administration, such as welfare benefit and its disqualification, would also be highly related with the concept. Since there tends to be no doubt or suspicion about its impartiality or disinterestedness in other area of judicial function, we often have not been sensitive to scrutinize the judicial role of civil disputes. The adversary parties are equal and the state can well be neutral to administer the civil justice oftentimes. Given the public sphere, the state is an interested party that may prejudice or be abusive to fulfill the state goals that the rule of law or due process of law is an important stroke to ensure the public lives on equal and humane virtue. The due process of law has dual ambits, namely procedural and substantive. For example, it is notable in this week that the right of privacy is one of fundamental right, though not specifically enumerated in the provision of Constitution. In Griswold v. Connecticut, the Supreme Court struck down the state statute banning the use of contraceptives to prevent pregnancy since it is repugnant to the requirements of substantive due process (1965). It violated the frame and spirit of constitution that the Government should respect the rights of individual. This opened a trajectory of subsequent case laws on the right of privacy leading to Roe v. Wade, Casey v. Planned 
Parenthood, and so (Roe et al. v. Wade, 1973). The substantive due process triggers the protection of classic liberty and equality in extent as intertwined with the state intervention, so that the Court would order the protection of property rights and ensure the contract freedom, and etc. In cases, the Court would weigh in the legitimacy of social legislation with the classic notion of private virtue as in the case of Lochner. The right to counsel would be shielded from the right to procedural due process, in which case the right to counsel and due extent of hearing or debating opportunity should be preserved as a matter of exchange.

\section{The Influence of Court Decision}

The influence of this decision on the levels of government shall follow since the Supreme Court enunciated important guidelines in establishing and maintaining the criminal justice system.

First, the influence tends to reach the state government predominantly since the criminal jurisdictions are generally vested within it. A piecemeal deal of federal criminal statutes would, however, shall honor to incorporate the standard of Gideon. Importantly, the model penal code or criminal procedure may have to reflect the proposition of Gideon that would guide the state practice of criminal authority.

Second, the imposition of stricter standard could lead the controversy of fiscal crisis for various states. For example, the state of California may claim a fiscal burden that could resist to respect more than affords beyond the least of elementary bottom. As we know, some criticism pointed out that the fiscal crisis in that state had been depraving enough to curtail a due extent of provision of judicial service. This may implicate a minimal response with the rulings, which brings us a new context of court battle on the right of counsel. This "forward and backward" would be a typical process of interchange in the US system, as we note in the death penalty issue, and especially probable if the court rulings were to be less expositive from various reasons. We also may be concerned of what scope of opinion actually binds other branches and levels of government. Is the binding effect limited to the main holding or other scope of terms, rationale and even rhetoric of court opinion? The State of Florida is a disputed party in Gideon that it seems highly unlikely to resist in instituting any more than affords. The case is rather straightforward in the end that there would generally be no lawyerly wisdom to escape the rulings from a fiscal rationale.

Third, its influence has been received by other jurisdictions, such as Korea, that Korean government manages a corporation of public counsel to advise on and defend the criminal interests of defendant. Nevertheless, the law of criminal procedure recognizes a limited extent of mandatory provision for the state-employed public counsel that a certain scope of heavy penalties exclusively could qualify. It may be exemplary that the Korean government founded the Korean Legal Aid Corporation (KLAC) on Sep. 1. 1987 based on the basis of the Legal Aid Act. It managed nationwide one headquarter, 18 chapters, 40 local branches, 67 sub-branches, and KLAC law-related education center (2015). The number of employees as updated Sep. 1, 2014 is 1,207, and its main business covers a legal aid, legal education, as well as study and research on the legal aid systems. It provides "legal advice and legal representation by attorneys both for civil and criminal cases to the public, especially those without financial resources and legal knowledge (2015)." Attached you will find the chart of work flows and the divisional role to serve the public. 


\section{Some Reflections on the Court Role}

Once again the decision and court opinion are an element within the general understanding of law at least in the common law countries. A lawyerly way has implications in shaping the pattern of public administration, but in differing extent of public attraction or normative impact.

First, while the Constitution of United States had brought a popular democracy and Constitution-based structure of government, the Ancien Regime had been overhauled in new land (Glendon, Carozza, Picker, 2014). The "nobility" as a basis of government was dispelled, and people arose as a main class or pillar of nation. As we take a precept of chaotic years from the Articles of Confederation thorough the Constitution, the earlier ambition was mixed between the diplomatic unity and one strong national government. This context implicates much over the centuries and can also be illustrated with a residue of classic and present practice of international politics. In the consonance of realist view, the nobility is any powerful ingredient to sustain the Concert of Europe upon the end of Napoleonic war, in which four major powers consolidated to defend the regime of monarchy. The consolidation has served the collective security of Europe which, however, super-intervened the revolutionary sprit of Europe and generally negated the quest of popular democracy. The kind of approach still remains same that governs the structure of UN Security Council, i.e., five nations regime with a veto power to ensure the collective security in the world. Hence, in the dimension of power, especially on the international plane and partially in the realm of international law, we may be incorrect to state that "people" are a panacea of value source other than some "structured or organized strand of history." Hence, under the influence of European civilization, it is no surprise the Constitution in that period is the document of government, more precisely intergovernmental or interdepartmental identities or ways of function, which dealt as less envisaged to touch on the public or legal lives of subject (Kim, 2014; Reinhardt, 1994). The characteristics as temporal for the years would more properly be sensible with the kinds of description, for example, "atmosphere of war, interstate comity or discredit, chaos from the heterogeneous regional power and social incongruence nationally." A threat from the mainland Europe had been constant at considerable period of time upon the independence. For the nation, it is more urgent to make it clear who will decide the will of nation, how to effectively consolidate the function of government, or how to manage the least of nation with the subjects than active interaction with the people, although the people are one distinct element of new Constitution and ideologically pronounced in the preamble of Constitution. This generally led to recognition that the role of Constitution and Supreme Court were minimal in terms of public policy making and that their policy contained in the opinion often is sheer of internal issues among the public power other than those of people (1994). The kind of Kantian ambition for the universal justice on liberty and equality, hence, should wait for more prosperous time afterwards that people tend to be conscious of their basic rights or public good from the arbitrary rule of majority, given our concocted recognition from the kind of public policy ideals from Bentham, "the greatest happiness of greatest number," and "revolutionary spirit on people."

Second, it perhaps would not be irrelevant, in understanding of the impact of judicial rulings on public policy, that the US is other than unitary system of government. Oftentimes the kind of rulings on criminalization of adultery or right to privacy would surprise the people, but the kind of oxymoron or public debate, as likely persistent over the decades and diverse reaction, would normally not be present in the jurisdictions of unitary system. The people of 
such jurisdictions would be more than receptive, and be readily marshaled to adapt with the public guidelines elucidated by the court ruling. As we see, G. Washington was a surveyor and the economic relations are mainly on agriculture at that time. This implies the importance of proper size of state, what we see the kind of important unit in terms of public law and public administration. South Korea or England normally would equal a respective state of US in terms of territorial size, which is related with the proper and suitable administration of public affairs (Glendon, Carozza, Picker, 2014). This can, of course, be surmised that some contingencies can well exist. Germany may be the kind of adequate state to practice a unitary system of government in consideration of size only. A historical context for the spread of small local powers may be one reason for their federalism while the European politics, such as balance of power, might be another reason (2014). The "structure of people" is also one factor to portray the role of judicial power that we need to ask, for example, "how the nation is comprised of race or ethnicity, foreigners and other trait of cultural identities." While we see implications of immigration in the evolution of world civilization, we note that the immigration into new Republic certainly pounded any significantly the role of government and public lives of people. Still the concern had hit even in Europe with Muslim people and perhaps one of very sensitive agendas in the next presidential election. Under this backdrop, it would be no surprise that the judicial power of United States is situated in some distinct historical and present conditions of nation, i.e., a typical of diversity paradigm within elements and fifty states federal union. We would know, for example, some states would be of Mormon ethos and other states may be with the civil law traditions. Some states may be more clustered with foreign immigrants while the inland states may be more nationalistic. We also chat on the multiculturalism in the society and workplace. Given the judicial activism, the Supreme Court justices might be clairvoyant, who would be equipped with goodwill, wisdom and almighty intelligence to assuage an untreatable scope of interests and state specificities (Graglia, 1994). Foreign lawyers would find such ample source of laws in surprise, who might envy a wide coverage of judicial interests. They perhaps would take the US context as the kind of insightful classroom and learn the lessons from their case laws. 


\section{Reference}

Graglia, L. A. (1994). Do judges have a policy-making role in the American system of government? Harvard Journal of Law \& Public Policy, 17(1), 118-130.

Kim, Kiyoung, The Constitution and Tripartite System of Government: From the Mutiny for the Limited Government Through the Interbranch Subtlety. (September 1, 2014).

International Journal of Advanced Research (2014), Volume 2, Issue 9, 392-401. Available at SSRN: http://ssrn.com/abstract=2574711

Korean Legal Aid Corporation. Retrieved Mar. 12, 2015 from http://www.klac.or.kr/main.jsp

Pardo, M. S. (2005). Disentangling the Fourth Amendment and the self-incrimination clause. Iowa Law Review, 1857(47).

PBS. (2006). Map: State Regulation of Abortion. Retrieved from http://www.pbs.org/wgbh/pages/frontline/clinic/etc/map.html.

Reinhardt, S. R. (1994). The Supreme Court as a partially political institution. Harvard Journal of Law \& Public Policy, 17(1), 148-153.

Roe et al. v. Wade, 410 U.S. 113 (1973).

Vile, J. R., \& Menez, J. F. (2010). Essential Supreme Court decisions: Summaries of leading cases in U.S. constitutional law. Lanham, Md: Rowman \& Littlefield Publishers. 


\section{The Commerce Clause and Federal Power}

\section{On the Commerce Clause}

The Constitution of Article I, Section 8, Clause 3 provides, "The Congress shall have Power To regulate Commerce with foreign Nations, and among the several States, and with the Indian Tribes." The clause is one of enumerated powers for the federal government, together with many others, for example, the contract clause and the power to raise navy, within the federalism. Although the long history of nations eventually constructed a powerful Congress in the world, the structure and provisions originally were expected of limited Congress that, in my view, perhaps three significant clauses, i.e., commerce and contract clauses as well as necessary and proper one, would serve as a legal basis to enlarge the authority and jurisdiction of Congress. The commerce clause grants power to regulate commerce within the Congress that entails an important connotation between three entities above and federal government (Vile \& Menez, 2010). The basic elements of commerce clause can be described briefly.

First, the commerce is one of important phenomena not only within the state, but also in terms of interstate or international interchange. The state generally exercised an authority to regulate the commerce for provision of its basic needs, privately and publicly. It generates a tax base that the governments can manage their public role and responsibility, and constitutes the might of nation in any important strand. The commerce state is the kind of mild expression interchangeably used with the warrior state that symbolizes the earlier of imperialistic experience. The Calvo clause, for example, would be one of stark example that the imperial expedition faced with a challenge in terms of protective homeland measure and local resistance. The commerce and trade still are structured as any sensitive and strategic area in the international relations that the aspiration of nations had established a rule-based regulation by inaugurating the WTO regime. While we note the progress of EU integration, we generally have an awareness that EU basically is a commerce-centered regime with the ambition of one government in the end, at least for the federalists of European Union (Glendon, Carozza, Picker, 2014). Since the wealth and commerce is a reality of economic relations, discourse on the commerce and federal regulation would perhaps be any crucial strand intellectually with the American realism of law and legal institution. In other words, it would be an important query to them, that is, how to structure the liberal market in the nation upon the real dynamism of market and normative conditions of Constitution.

Second, the question of commerce clause involves importantly with the normative requirement as the Constitution provided. The situation was the kind of post-war instability as apprehended in a general ethos of pubic with the constant fear of foreign aggression.

Nevertheless, the Constitution did not speak much how the nation and the regulatory function should be understood in the chaos of many distinct elements (Kim, 2014). Some states may not prefer an expanded role of federal power and others may urge a stronger union to diminish the fear of foreign threat. Several earlier cases on the commerce clause generally can be viewed to "marshal this uncertainty into some rules of coherence as a nation" and through the effort of Marshall-led Supreme Court (Vile \& Menez, 2010). The provision grounded three elements in express terms, i.e., foreign nations, Indian tribes and several states. This implies (i) the federal government is granted neither the general police power nor even some scope of commercial power exclusively intrastate (ii) the power to regulate the commerce within the state is reserved comprehensively with the state based on the Tenth 
Amendment (iii) the federal government shall be an arbitrator of commercial flow and trade other than active policy makers on the national issue of commerce (iv) the "several states" tend to raise a wide of controversy more than foreign nations or Indian tribe since both governments operate under one Constitution and share the scope of regulatory issues in common. Over the development of case laws, the Court ascertained that the federal regulations of commercial activities may be divided into "three broad areas- regulations of the channels of interstate commerce, the instrumentalities of such commerce, and activities having a substantial relation to interstate commerce."

\section{Cases in Thoughts and Court Tendencies}

In review of historical wake of case laws, we can derive some important mainstreams in terms of its effect and implications, so that the Court acted on the jurisprudence of commerce clause in differing ethos.

The first group pertains to an earlier precedent that the Supreme Court emphasized the significance of commerce clause in the end to empower the Congress with a due extent of authority to regulate the state actions. This tendency facilitated the needs of nation for unity and with the representative government of Republicanism. In Gibbons v. Ogden, the Court ruled that the state regulation against a licensing act of Congress is deemed unconstitutional since it infringed with the commerce clause (1824). Ogden was assigned the right, by the State of New York, to operate in the river between New York and New Jersey Ports which conflicts with the license of Gibbons to navigate the river and based on the congressional act. As in same logic with Marbury v. Madison, the state law repugnant to the federal state was deemed invalid since the latter is supreme. The metaphor echoes as similar with jurisprudence of federal supremacy while the court articulation was not detailed in that frame. In Brown v. Maryland, the Court had ascertained an inherent role of federal government in regulating the foreign commerce (1827). The issue could be resolved more straightforward that the original package of imported goods could obviously exclude the state authority to require a license. The power to license an import and export as well as levy a tariff is surely a subject matter of federal jurisdiction as confirmed in the commerce clause.

The second group can be termed especially through the New Deal era involving the social welfare promise of nation. If the first group is characterized to fortify the kind of classic-virtue nationalization, the second group would be the pop-driven nationalization to extend the fruit of industrialization to the whole of people with the ideal of social justice. The term ironically would be roughed around between the classic music and advent of fork song or some lately pop music. In this line of cases, The Court in the West Coast Hotel is illustrative together with several other cases, i.e., Schecter Poultry Corporation (1935), Carter (1936), Darby Lumber Co. (1941), Wickard (1942). The case arose from the state regulation to "prohibit wages below a living wage and conditions detrimental to the health and morals of women and minors." The Court rejected an argument on the freedom of contract which actually was not a literary component of Constitution, rather shed a due consideration on deprivation of liberty without the due process of law. The Court had upheld the state measure as a broad protective power which probably coheres with the ideal of promoting the general welfare through both levels of government in common. In the preceding decades before a re-election of Roosevelt, the Supreme Court struck down every element of New Deal legislation. The first two cases were some outcome in that period that the traditional non-delegation doctrine played to bring an invalid use of congressional power 
and that mining activities were deemed not a commerce so as to claim the ground of federal regulation. While the President rolled back with the "Judicial Procedure Reform Bill" in 1936 the progress turned positively what we are known as the "switch in time that saved nine." The production of goods shipped across the state lines began to be duly regulated by the federal power, and significantly furthered that the changed minds of justice endorsed such distinct trait of intrastate production and consumption of wheat, reaped even with the purpose of purely home context, in the end of national price control.

The third group would be charted in terms of "institutional adjustment," which focused on the interstate discrimination rather than the power of Congress. Hence, the Court treated several states as the kind of subjects to compete, but on the equal conditions of trade. The idea may be similar with the traditional value "level playing field" in view of the regulation of international commerce among states or equal protection of law for several licensed businesses upon the revocation case (Wilkinson, 2014). This trait noted in the practice of Supreme Court is generally termed as the "jurisprudence of dormant commerce clause." Since the Court appropriated an original intent of clause in a differing and mechanic way and by averting its focus to the equality among the states other than the basis of congressional power, the clause may be said to be dormant. Over the trajectory of dormant commerce clause jurisprudence, the inherent thought would lodge between federalists and moderators, exemplified as James Madison and Roger Sherman. The federalists argued that the state should be barred from imposing the duty of tonnage while the latter proposed a concurrent jurisdiction dealing with the imposition and regulation of interstate commerce between the states and federal government. The structure of debate bears a same attribute with the state and national taxation, and of course, two of important functions of government in managing the fairs of state and nation-state. One view from M.S., Kim, an influential Korean politician, commented to corroborate in the recent Presidential meeting, "the economic agenda is such sensitive and profound if 90 percent of work and responsibility would be concerned of it (Kim, 2015)." The tax and regulation of commerce are any more important strand since it creates the basis of fiscal scheme and structure the national market for the free flow of commodities and fair play among the states and businesses. The dormant commerce clause requires to regiment on the subjection of state authority if to regulate in a discriminatory manner. The idea is that a differential treatment of in-state economic interest and out-of-state economic interests is deemed unfair and against the assumption of state equality inherent in the sprit of federalism. To put simply, the state is constitutionally obligated to avoid the measure to benefit their state economic interests and burden other states. The thought was framed in earlier years as called a "formalistic approach," in which the Court look at the measure of states from three kinds of attribute, say, manufacturing $v$. commerce, direct and indirect effect as well as local and national. This generally brings that the state government shrunk in its scope of regulation, but the Court would intervene to enliven or to chill the state measure in the ambit of federalism and institutional adjustment of liberal market. As justice Stone remarked, in his dissenting opinion in the Oklahoma Tax Commission v. Jefferson Lines, that it was "too mechanical, too uncertain in its application, and too remote from actualities, to be of value," the formalistic approach declined gradually and in some significance with the influence of New deal politics. The commentators view that the death knell of formalism occurred in the Complete Auto Transit v. Brady (1977). The formalistic approach requires the judges look into the content-based or subject matter distinctions leading to semantic or formalistic frame of rules, who glouted to embroil into complex social or political issues of progress and diversity. They may like to remain a normative deliverer of constitutional meaning, but the Court should be tasked with a scope of 
public controversies upon the transformation of social virtues and public administration. The Court had actively been called upon to deal with new issues, such as public health and safety or environmental issues, so that it began to modify the strict stance originated mainly from the issue of state taxation. Afterwards, the local processing requirement was developed to follow up with the generally creative power of state. As reverted, the issue involves the boundary of regulatory power between the state and federal government. The former is granted a comprehensive power to police or regulate no matter if the jurisdiction is on commerce or manufacturing. On the other hand, the federal government must be confined to the list of powers enumerated in the Constitution. A strict adherence with the jurisprudence of semantic emphasis, would lead to an effect that both levels of government will diminish in power if the Congress could not regulate a manufacturing while the state may fail to enact the laws of commerce in certain scope of nature as ruled by the Court (Bragg, 2010).

Nevertheless, we would never be definite to say that a formalistic thought would not reoccur because it also could be more adequate as to be instrumental to deal with the challenges from the national and social transformation. This may be the point of lesson that the designers and practitioners of institution are required to be adjusted with the fair and progressive justice between the principle and social change. This aspect was once pointed out by one justice, "the Commerce Clause significantly limits the ability of States and localities to regulate or otherwise burden the flow of interstate commerce, but it does not elevate free trade above all other values (United Haulers Association v. Oneida-Herkimer Solid Waste Management Authority, 2007)." In the period, the court would use the kind of terms or rhetoric, "unduly burden the interstate commerce," "brings a discriminatory effect," "clearly excessive in relation to the putative local benefits" (Minnesota v. Clover Leaf Creamery Co., 1981), "protectionist state legislation as regulatory measures designed to benefit in-state economic interests by burdening out-of-state competitors" (New Energy Co. of Indiana v. Limbach, pp. 273-74, 1988), "burden the flow of interstate commerce interfere with the trade among the states" (Quill Corp. v. North Dakota, 1992). For the dormant commerce clause, we generally acknowledge two exceptions, i.e., congressional authorization and market participation activities of state. The exception has a ground because the Congress has an ultimate authority to regulate the interstate commerce and because the state would be deemed as one of commercial actors other than governmental instrumentality when it engage in activities as a market participant, such as contracting with private partners or selling the public parks. It may not clearly be agreed, however, to determine if the state acted as a "market regulator or market participant." For example, the selling of public park or tolling a park fare for the active travelers may not be same.

The last group may be typified with the Rehnquist Court, in which the state sovereignty surged and the commerce clause had been interpreted in a narrow or limited ambit and purpose. Some may excoriate his federal passivism while the advocates support that the national compassion should be fostered in that ambition for the purpose of boosting the autonomy and root vigor of several states. The United States v. Lopez is alleged to be in line with this stream of court policy. The case involved the Gun-Free School Zones Act of 1990, which prohibits possession of handgun near schools (18 U.S.C. § 922, q). Lopez was a twelfth grade student who carried an unloaded gun and was convicted of violating the act. As grounded on the first principles, the Court returns to the orthodox of constitutional dictate that chilled the expansion-driven use of commerce clause by the previous courts, unless the commercial nexus or substantial effect on the interstate commerce is established. Between the economic activities and criminal statute, the Court cast a strict yardstick to distinguish a gun control policy from the economic activities. Although the criminal jurisdiction is 
constitutionally vested within the state and the jurisprudence of commerce clause cannot usurp an express language of constitution, we may recall if Lopez would have carried a "loaded gun" to impose a substantial threat on the peers and teachers and if such increased culpability would bring a different result?

\section{The Federalism and Commerce Clause}

In advent of progressive ethos across the world in early of $20^{\text {th }}$ centuries, the "classicvirtue nationalization" began to be contested by the thrust of public quest on social justice and humanly condition. Traditionally, the slavery and production relations therefrom could be some of effective bumper to subsidize the economic needs and consumption of nobility. Upon emancipation of slavery, the universalization of human rights saw a substantial achievement around the civil war, and equal suffrage on gender had been struggled to success some later in time. The industrialization rapidly progressed and the market to sell the goods of mass production had been competitively expanded. The Mill's idea and philosophy engrafted more practically in depth with the liberty virtue earlier revolutionized and one critique on the depravation of capitalist framework would argue on their cause dialectically and in the way of quasi-religious approach. His prophecy was realized in $19^{\text {th }}$ Russia, and later in China upon the chaos of imperialist contest. The social philosophy had grown in early of $19^{\text {th }}$ century in reflection of the capitalist failure in terms of social justice and welfare, which may well be noted in the Beverage Report and increasing sentiment on public dimension other than the selected class of capitalists, perhaps new nobility envisaged in the late of $18^{\text {th }}$ century, contested during the civil war and starkly fronted around the turn of $20^{\text {th }}$ century (Glendon, Carozza, Picker, 2014). Upon the participatory paradigm in a wide of public interest, one important tendency in the frame of government and politics must be mentioned that the party politics reshaped its attribute from the share of local potent through the increasing role of professional politicians. Together with the universal and equal suffrage, it rose as a factor to pull forward the public participation and pop-driven policy making. Although we revere the spirit and approach, "the people of United States..." in the preamble and admire Bentham's idea, "greatest happiness for the greatest number," its character had to be struggled over the century given the structure of economic relations, basic social arrangement, and prurient interest of governing class.

The informative society and sharing of awareness also contributed to wheel the society ahead on progress that classic-virtue judiciary had to face with the challenge at the moment of square aspect of chaos in early of $20^{\text {th }}$ century. A real mask of public or popular democracy had inculcated the society to posit a paradigm change in administering the state agendas. Once again we question if the Supreme Court is a judicial or political organ? The German legal science became enriched as indebted to the sociological studies of law around the turn of $20^{\text {th }}$ century, but it also would be true if the Rhine river jurists remain to manage on their business like a clerk looking way and the approach may be for those of legal academicians (2014). The intrinsic of judge's role would not be such generally as to spell out a long opinion although the major style differs between two legal traditions. A powerful context of judicial role in the common law countries probably shall stem from their judicial style that we often perceive if the legal education and professional attitudes have split in sensibility of professionals. In those countries, the judges are attributed as greater reliance and professional trust or worship, which is in an interesting contrast with their civil law counterparts (2014). The judges and lawyers would tend to revere law professors and may function under the implied network of advice and dialogue with the legal academicians. This implies that active players in speaking more about the society could centralize the loyalty of 
peer professionals as many books and articles normally may be the basis of professional reverend in the academicians. This perception is not to say that the judicial activism or political role of judges is desired, but to elicit the environmental demand across the politics, economy and social needs or changing purview of humanness can locate a proper function of judiciary (Heart of Atlanta Motel, Inc. v. United States, 1964).

The federalism and separation of powers principle, the kind of limited or checked government, had created a due division of power or extent of intervention, in which earlier justices shall be diligent to enlighten the classic virtue commerce clause. The new deal of social restructuring brought a second nature of judicial activism, in which judges must turn to receive a new intellectual view of social justice and be active in consonance with the political initiative. As noted, the judicial ways to resolve a dispute involving the commerce clause could be made distinct in some sense. For example, it is conservative to ask what the commerce means or if mining activities in such industry falls within the legal definition of commerce. In Schechter, the Supreme Court applied a non-delegation doctrine to reject the new deal bills in the first attempt, which shows a loyalty to the traditional orthodoxy of separation of powers principle (A.L.A. Schechter Poultry Corp. v. United States, 1935).

For the first jurisprudence of commerce clause, we also have a connotation that the Court has exerted a focus on how to shape the workable Congress and to safeguard the federalism if their crucial question is what the congressional power can be defined from the commerce clause. For the period of dormant commerce clause, the Court would pay a due consideration for the purpose of duly integrating the States and supervised to quell a discriminatory measure among the states. Hence, the Court in these roles can be said of neutral quality between the "conservatives and progressives," since the issues are of structure and governance. As a pun, it can be ascribed as conservative if the government eventually became proactive to promote the classic liberty and equality of states that resulted in subjection. Given that a wheat production, grown to the use of home consumption, had been rendered as commercial activities, the Court extended its rules deviating from a faithful reading of Constitution. The scope of commerce gradually had expanded in applied understanding, and a metaphor, rhetoric, and basic disposition might be staged in not same way from the past, which was to emphasize, "the liberty safeguarded is liberty in a social organization that requires the protection of law against the evils that menace the health, safety, morals and welfare of people" The kind of terms or descriptions on public policy or sensitive political issues were dealt, and progressively in those times (Bragg, 2010).

\section{Three Cases under Review}

In the Circuit City v. Adams, the Supreme Court was called to decide "whether the section one exemption" of the Federal Arbitration Act applied to an employment contract of an employee at the Circuit City Stores (1926; 2001)" Adams was an employee of Circuit city as a sales counselor, and his employment contract required all employment disputes to be settled by state arbitration. Adams filed an employment discrimination law that sought to enjoin the state court action and claims to settle the dispute with the Federal Arbitration Act. The Act prescribed a limited scope of professionals, in coverage of seaman, railroad employees and any other class workers of foreign or interstate commerce, who statutorily were excluded from the competence of federal arbitration jurisdiction. The Ninth Circuit Court of California denied the claim of Adams since he was excluded from the scope of federal arbitration. The Supreme Court, by 5-4 decision, held that that "the exemption was limited to the specific listing of professions contained in the text" and ruled that "general employment contracts, like the one Adams sued under, would have to be arbitrated in 
accordance with the federal statute (Circuit City Stores, Inc. v. Adams, 2001)." The Ninth Circuit later found that the employment contract was unconscionable to preclude the arbitration proceedings and ruled that the regular court procedure should be a fair way to resolve the disputes. The case is less direct if the issue is a kind of interpretive disagreement over the scope of professionals amenable to the federal arbitration proceedings. The Court found, by invoking the traditional interpretive rule, maxim ejusdem generis, that the legislative intent essentially focused to include the "transportation workers" in providing an exception of professionals (2001). The dissent perceived even the federal arbitration, implied as same of state arbitration, cannot fairly protect the interest of employees given the disparity of bargaining power between the employers and employees. If the federal proceedings would be designed as superior to the state ones, the attraction of FAA would become popular so as to be disputed around the commerce clause. Nevertheless, the Act would be more properly viewed other than an issue of federal regulatory power, but a procedural provision to promote the general welfare of nation. However, since the FAA deals with the state civil jurisdiction and contains a compulsory quality in part, the FAA can be more operative if the contract of employment is predicated upon the interstate commerce. Essentially, however, the federal arbitration would unlikely be to mandate a jurisdiction as a requirement of law or regulation, but the private parties or public employers may agree on the application of Act to their contract of employment.

In Morrison (2000), the Supreme Court held that "parts of the Violence Against Women Act of 1994 were unconstitutional because they exceeded congressional power under the Commerce Clause and under section 5 of the Fourteenth Amendment to the Constitution." The act provided that the victims of sexual violence can claim a federal civil remedy. In this case, one freshman student at Virginia Tech was allegedly assaulted and raped repeatedly by fellow students, named Morrison and Crawford. Morrison was punished with a suspension, but the evidence was insufficient to charge them in the criminal proceedings. The victim filed suit under the act, and the District Court held that Congress lacked the authority to enact for the provision of federal civil remedy under either the Commerce Clause or Equal Protection Clause. The case involved the scope of federal regulatory power as distinct from FAA since the latter would be of advisory nature and provides the rules and standards ultimately chosen based on the selection of parties. The Act in this case is to mandate the federal civil remedy under certain conditions that is deemed as compulsory or regulatory in nature so as to govern the sovereign power of States on civil adjudication. The Court, hence, invoked the standard of Lopez that the federal power, in its intrinsic, should be of enumerated scope and stressed "a distinction between what is truly national and what is truly local (2000; Gun Free School Zones Act, 1990)." In this subjugation of federal power, it is noteworthy that Lopez and Morrison had dealt with two essential responsibilities of State including the criminal justice system and civil adjudication. Hence, the Court cited Boerne, "... in order to prevent what the Court described as a considerable congressional intrusion into the States' traditional prerogatives and general authority (2000)." The Court also distinguished between the attenuated effect and substantial one on interstate commerce, and rejected the argument on the aggregation principle that the acts of violence can be proven to have a substantial effect with a mountain of evidence. In the court holdings, the decent standard of federalism may be impaired, stating "to completely obliterate the drafter's intention between national and local authority (2000). The Court also rejected the argument on the Equal Protection Clause that the Congress properly appropriated its constitutional authority to ban on the governmental gender discrimination. The state action theory was cited to legitimate a nexus with the requirement of Acts and attempted to constrain the private individuals. The Court ruled, "...the VAWA still was unconstitutionally aimed not at state actors but at private criminal 
conduct (2000)." I generally agree that the Court had disposed the federalism in any nuanced fashion and with the consistent web of metaphor to protect the original intent of drafters. Nevertheless, it may impel to consider some of realistic sensibility between the people, an individual and constitutional value as seen later.

The Atchison is a simple case showing between the intrastate and interstate regulation of commerce, which could be analogous with the earlier case, Gibbons, in view of logical structure (Interstate Commerce Comm. v. Atchison T \& SF R Co, .1914; Gibbons v. Ogden, 22 U.S. 1, 1824). The haulage rate of railroad would be a subject matter of contention in this case, while a license to navigate the interstate river had been contended in Gibbons. The nature of regulation would be intrastate in orthodoxy or formality, but the Court could rely on the effect theory and infers an interstate nature on the stream of commerce. The effect theory provides the ground of federal power to expand the use of commerce clause, and the idea would also provide one of notorious legal dogmas in the anti-trust laws or compulsory disclosure of evidence in the pre-discovery hearing, which had long been critiqued as extraterritorial application of domestic laws by the international lawyers. The effect theory to deal with foreign jurisdictions would find its constitutional ground on other clauses or different context of statutory basis, such as the federal rule of civil procedure, but the idea can have same strand with the effect theory of interstate commerce. In Atchison, Texas managed a dual rate of haulage charge in view of distance and across the intrastate regions that the ICC ordered the railroad to charge similar rates for similar distances within and between states. The Court ruled that "in fostering and regulating interstate commerce, Congress may take all measures necessary or appropriate even if that means affecting intrastate commerce as well (1914)." Given the evils of social injustice and public harms over the industrial development and material growth in the nation, the regulation of ICC should be preferred to grant a more available extent of authority in exercising a federal regulatory power. Given the limited scope of enumerated powers of federal government, I may agree that the commerce clause would be a most effective basis to authorize the federal power.

\section{Thoughts on the Federal Regulatory Power}

The cases to brief on the commerce clause in connection with other constitutional clauses and federalism had been in kinds which involves a simple showing of dynamism through criminal and civil jurisdictions. This choice is considered helpful since the criminal and civil jurisdictions are such traditional function of government intertwined with the state power of regulating the industry and commerce, the kind of three intrinsic assumed to recourse "what the state actually is of any quality." In the discourse, we once again would be reminded of the nature of federal constitution, one of classic invention, but very in a revolutionary context. No document had ever been existent that structures the government in terms of its power and responsibilities before its inauguration, although we can witness a set of individual rights, such as Magna Carta in $13^{\text {th }}$ century, bill of rights in $17^{\text {th }}$ and those of several states before attaining an independence (Glendon, Carozza, Picker, 2014). The Constitution of United States must be a good classroom in view of the studies of government. Especially over the three cases, we can be indebted much in basics since the power to arbitrate the civil disputes and address its own criminal system is two essentials centering at the regulatory power of state while the issues of commerce entails a strand of balkanization dilemma for the state, given the kind of guardian role to protect the commerce of state and as a neutral umpire to administer the justice of commerce. Between the dual forms of State, namely the United States and various states of nation, the drafters of Constitution preferred a 
decentralized form of government because of the bitter experience of tyranny, and the kind of Gallicanism in $14^{\text {th }}$ France under the rule of Philip IV or nationalization exert of Henry VIII could not be a moment in any earlier of independence age until the civil war internally and two world wars externally (2014). Two incidents also generally are considered as a landmark of modern progress on democratic thought realizing the classic and progressive emancipation to universal liberty. A negative liberty from the intervention of government and positive liberty to the decent humanity had been strived as a public ideal. As previously, the protection of individual rights mostly within the Amendments is not a distinct avenue separated from the reading of government, although the language of Constitution in the main text had been pompous over more than two centuries. That is true of the general awareness of State as needless to mention three notorious elements, say, the sovereign power, people and territory. The role and responsibility of State traditionally is understood as to police the community and protect its people against the foreign aggression. The limited government had proven effective to ensure the liberty of people, and the federalism had been designed successfully to safeguard the civic virtue. On the other hand, the proper division of power and responsibility in occasions posed the challenge that perturbed intelligent and minded neighbors on sensitive public issue, such and sex crimes and gun violence or regulatory needs (Vile \& Menez, 2010). Provided if people would be any ultimate source of authority and legitimacy of government, we may not be insensible if it would go odd with poor victims, but with remedies extant from the laws, but eventually no remedies from the court ruling of structural inconsistencies. A remorse would unlikely be dispelled from any articulate or sophisticated rule given the unresponsive government in gaps or ambiguities. The Constitution is a norm that should be certain, consistent, and predictable to govern the legal relations and whose addressees would be a government and public employees other than an individual. That is a general theory of law as instrumentally and technically, and we may retract if the Court role is to clarify and confirm the idealistic and normative structure of government, hence placing a standard on and giving predictability to such addressees. We may still be unresolved, however, provided if Christy had been deprived of pronounced protection, who would perhaps be stupefied around an ambitious word of federal statute, unresponsive or lazy state government, and general ethos of public on her side (United States v. Morrison, 2000). We also may echo if people, and indirectly an individual, would be an ultimate source of constitutional value, and that the Court had been active to enlarge the operation of FAA, not perfect though, by denying to see the scope of exemption as inclusive. The Court seems to allow many perspectives standing that upheld a restrictive view of state action theory or the kind of ideas, such as federal common laws on civil damages in VAWA (FAA, 1926; VAWA, 1995). 
Reference

A.L.A. Schechter Poultry Corp. v. United States, 295 U.S. 495 (1935).

Bragg, A. (Producer). (2010). Wheat, weed, and Obama Care: How the Commerce Clause made Congress all-powerful [Video file]. Retrieved Mar. 12, 2015 from

http://reason.com/blog/2012/06/23/vid-wheat-wheat-obamacare-how-the-commer.

Brown v. Maryland, 25 U.S. 419 (1827).

Carter v. Carter Coal Company (1936).

Circuit City Stores, Inc. v. Adams, 532 U.S. 105 (2001).

Complete Auto Transit, Inc v. Brady, 430 U.S. 274 (1977).

Federal Arbitration Act of 1926. Pub.L. 68-401, 43 Stat. $\underline{83}$.

Gibbons v. Ogden, 22 U.S. 1 (1824)

Glendon, M.A., Carozza, P., Picker, C. (2014). Comparative Legal Traditions, Text, Materials and Cases on Western Law. Saint Paul. MN: West Academic Publishing.

Gun Free School Zones Act of 1990, 18 U.S.C. § 922, q).

Heart of Atlanta Motel, Inc. v. United States, 379 U.S. 241 (1964).

Interstate Commerce Comm. v. Atchison T \& SF R Co. 234 U.S. 294 (1914).

Kim, J.I. (2015, March 18). Three Party Talks, The ChosunBiz, pp. A4.

Kim, Kiyoung, The Constitution and Tripartite System of Government: From the Mutiny for the Limited Government Through the Interbranch Subtlety. (September 1, 2014).

International Journal of Advanced Research (2014), Volume 2, Issue 9, 392-401. Available at SSRN: http://ssrn.com/abstract=2574711

Minnesota v. Clover Leaf Creamery Co., 449 U.S. 456, 471(1981).

New Energy Co. of Indiana v. Limbach, 486 U.S. 269, 273-74(1988).

Oklahoma Tax Commission v. Jefferson Lines, Inc., 514 U.S. 175 (1995),

Quill Corp. v. North Dakota, 504 U.S. 298 (1992).

Schecter Poultry Corporation v. United States (1935),

United Haulers Association v. Oneida-Herkimer Solid Waste Management Authority, 550

U.S. 330 (2007). 
United States v. Darby Lumber Co. (1941),

United States v. Lopez, 514 U.S. 549 (1995)

United States v. Morrison, 529 U.S. 598 (2000).

Vile, J. R., \& Menez, J. F. (2010). Essential Supreme Court decisions: Summaries of leading cases in U.S. constitutional law. Lanham, Md: Rowman \& Littlefield Publishers.

Violence Against Women Act of 1994 (VAWA). Pub.L. 103-322, $43 \underline{\text { Stat. }} \underline{883}$.

West Coast Hotel v. Parrish, 300 U.S. 379 (1937)

Wickard v. Filburn, 317 U.S. 111 (1942)

Wilkinson, R. (2014). What's Wrong with the WTO and How to Fix It Paperback, Malden. MA: Polity Press. 


\section{The Constitution and Civil Rights}

\section{The Civil Rights and Equal Protection of Laws}

In thoughts on the civil rights of aliens and public policy of nation, we would be driven to address the history and backdrop of the amendments. The initial set of bill of rights was introduced some years after the effect of Constitution. Thomas Jefferson, earlier thinker and one of founders for the nation, discussed the incorporation of bill of rights with Madison, which was thought ambiguous in effect since the express provision of individual rights could come negative by the biased or evil Congress (Vile \& Menez, 2010). They generally could not be firm if the codification could serve their purpose of enhanced protection for the individuals. It might be seen to them more effective if the rights remain natural to claim universal status as inviolable. At the moment of codification, the scope of rights and what shall be contained to compose the requirement of legal protection could enjoy a clarity and certainty as a matter of enforceability, while the operation should depend on the government and be subjected as the nation has a due cause and constitutional ground in addressing the national needs and exercising a public power. The initial ten amendments had some other purpose to assuage the strong opposition of Anti-federalists, who pursued to check the strong national government to the disadvantage of opposing states. Since the era had been contentious and the national need to consolidate was high against the threat of foreign aggression, the bill of rights can be a moderator to satisfy both positions.

The US constitution was created in 1787, and French declaration of rights of man was done two years before the amendments in 1791. The spirit could be shared under the mutual influence of chaos between two continents, and still working under the frame of universal declaration of human rights adopted in US after the two world wars. The concept and philosophy, henceforth, had a common root basis that inculcated the drafters of Constitution and may be referenced by the original intent adherents. What we generally connote with the word, civil (Nelson, 1998)? The "civil or civilization" perhaps be more a companion with the "politics or political." More accurate or in conservative view, it would be distinct with Royal. Both may contrast with the kind of words of our sense, "man v. boy, learned v. compelling, social or environmental v. industrial, consensual v. unilateral or regulatory, classic v. common, universal v. national, and so." The main text to structure the federal government might be enough for the founders, which, however, would lead a desolate of our public lives, in the least to wait for other evolutionary avenue of legal system. This context would perhaps be a primary reason that we often conceive a law as to protect the rights of minority, "discrete and insular" in the terms of art often used by the Court. Given the main text thrust the reality of US politics and frame of government, what do we have to infer any controlling strand from the amendments of civil right if the interpretive controversies arise involving the language of Constitution.

First, it entails a universal value of modern democratic government that the "civilized countries" should not have to be gone without a due regard of it. This aspect of belief would generally be widely held across the global jurisdictions as primary and UN as soft, but comprehensively (Kim, 2015). Hence, the legal theory and practice generally recognize the aliens would qualify for the essential class of human rights although they could not exercise a voting right or the right to be elected to the Senate or House. 
Second, the notion and compelling force cannot be negated in view of historical realism and hierarchy of political common sense that penetrated and had been demonstrated by the series of bourgeois revolutions, i.e., 16th bill of rights in England, 18th bill of rights in the states, and in France as well as that of federal constitution. The frame and institutions had been confirmed with the bitter history of struggle even over the last century, while we generally condemn a coup or insurgency for tyranny betraying the civil concept or value and especially under the auspice of UN Security Council. This aspect generally leads to the judicial realism in serious reflection of legal history and intent of drafters of Constitution. As the man or subject in the bill of rights would be shared in common grounds, at least in the continental progress, that is less on the national boundary, the strict views on the citizenship may defer to a wide apprehension if feasible. This proposition, however, could not maturate to include many of classifications into any due justice and for various grounds of governmental intervention (Dred Scott v. John Sandford, 1856).

For example, the status of African slaves had been contested because they are not treated as a human in terms of constitutional purpose or as the citizen of United States and until the civil war broke out, but subsequent amendments related with the facet of anchored dissension. Hence the rule of lenity to enlighten a fair scope of constitutional protection is never short to stress an importance in terms of protection of aliens, for example, working in the competitive civil service. Traditionally, the Court would apply the standard of strict scrutiny that requires a compelling state reason to regulate the category of aliens along with the races and some others.

Third, the evolution of civil rights concept would need to surmount a national resistance around the civil war period. The Fourteenth, Fifteenth, Thirteenth amendments were enacted in the harsh times to respond with the war of southern rebellion. The law had been a working instrumentality to situate the politics of nation. Thereafter, the Fourteenth amendment has been utilized as a bulwark of civil rights protection, which imposed the duty of state to extend the elements of civil right, life, liberty and property rights (Korematsu v. United States, 1944).

This revolutionized the framework of Constitution that the federal power, to specify, the Congress and federal judiciary, can be a supervisory body involving the controversies, which, in their intrinsic, falls within the state matter. Such revolution had stretched that judicial invention acknowledged a theory of selective incorporation under the ambit and scope of Fourteenth amendment, in which the state also should be bound by most of original ten amendments (Dittmer, 2013). In its inception, the bill of rights are the kind of feeble institution that the Supreme court had countenanced few of controversies, but the surge of judicial calls had been sought after the enactment of Fourteenth amendment and court practices thereafter.

\section{A Case and Analysis}

According to the immigration law, some class of resident aliens is federally required to register, in which we note that the federal government is empowered exclusively to create and implement the national policy of immigration and naturalization.

The plaintiff in consolidation with other three federally registered resident aliens filed a suit seeking a declaratory and injunctive relief against enforcement of statute, titled 
Section 53 (1) of N.Y. Civil Service Law (Sugarman v. Dougall, 1973). The section provided, "no person shall be eligible for appointment for any position in the competitive class unless he is a citizen of the United States." The four plaintiffs in class action were discharged in 1971 solely because of their alienage and shortly after they were transferred from nonprofit organizations to the city government. They sought, along with two remedies above, damages for lost earnings. While the defense motion to dismiss for want of jurisdiction was denied, the district court, relying on many Supreme Court cases, found that the section violated the Fourteenth Amendment (1973). It also ruled that the section is unconstitutional on the basis of the Supremacy Clause that was in conflict with the Congress' comprehensive regulation of immigration and naturalization. The Supreme Court affirmed the lower court decision. The court held that the aliens are a prime example of a discrete and insular minority and classifications on that basis is subject to strict judicial scrutiny (1973). Although the section 53 (2) stipulated a temporary exception to the citizenship requirement, the Court found "section 53 in whole sweeps indiscriminately and is not narrowly limited to the accomplishment of substantial state interests." The court noted that "the State had a legitimate interest in establishing its own form of government and having civil servants of undivided loyalty," but that the broad citizenship requirement established in the section could not be sustained (1973). The case was decided by 1 to 8 vote of justices, and Justice Rehnquist dissented on the ground that "the Fourteenth Amendment does not protect minorities other than racial minorities (1973)."

The rulings would guide the practice of federal, state and local governments although the Fourteenth amendment expressly used "state" as a norm receiver. A restrictive reading of section 1 of amendment would impair the spirit and will of Constitution given the intent was universal and against the abusiveness of levels of national government. That is not same with "inversed challenge" where the Constitution had dictate on the federal government. Since the state is vested comprehensively with a residual power unless the power of federal government is specifically enumerated, and the very operation of federalist approach, this view has to attain a logic and persuasion. The federal government also is one form of state to exercise a coercive power on the citizens and people, although the immigration and naturalization or federal employment would be regulated in no explicit limitations by itself. Hence, the equal protection of laws and due process of law principle shall be extended to the federal regulation. The local governments shall respect their state constitution that often replicates the same ambit of Fourteenth amendment (Nelson, 1998). There can we hardly find any argument that the local governments can enjoy other disposition given it would be a creature of state government, a point of difference with between the federal and state government. Otherwise, they would be categorized same to be subject to the ruling of Supreme Court in which both of state and local governments have to comply with its holdings. If the status of aliens, especially legal and registered ones, would be a vital component of national society that shall be treated equally, as the congruence and integrity of nation require so and once incorporated into the community. Economically, that is similar with the kind of notion, such as national treatment in terms of internal trade law, assuming that we view the issue in analogy. The decision would impact various levels of government that they shall define closely the statutory terms and requirements within care not to be overbroad and not to incur a sweeping effect indiscriminately. The citizenship restriction that will be employed within the statute and regulation has to be precise and should not prohibit noncitizens from jobs in a way that did not further the state interest (Sugarman v. Dougall, 1973). Nonetheless, the national circumstances depending on the state specificities, in terms of booming or illegal immigration, may compel the states to adopt a rigorous regulatory 
frame which can raise the federalism issue on preemption or scope of subject matter jurisdiction (Stern \& Straus, 2014). A recent controversy involving the Arizona statute on illegal aliens exposed a challenge of this kind, showing that the law would be a product of toils and social change. However, it would be in comport with the Constitution if the legal aliens would deserve a protection of Fourteenth Amendment especially if they are federally registered.

Justice Rehnquist view would be thought too restrictive if he had been narrowly confined to the intent of amenders around 1860's. It certainly had been triggered to revamp the prevailing evil of black slaves, but the national progress had guided the other way of awareness. The "civilization and civil society" would never be evolved in a restrained classification as briefed in the beginning of discussion. Being stepped into the shoes of bourgeois revolution, his interpretation still is seen to bias the reality of economic justice for equal opportunity to occupation and public office. The "people" against "citizen" in purview of section 1 of the Fourteenth amendment should also be read in a coherent manner with uses in other places of Constitution (Vile \& Menez, 2010). For example, the preamble used it in no restrictive sense to "form a union of domestic tranquility." Federally registered aliens are never separable from "domestic tranquility" given they are permitted to lawfully reside. If we are availed of narrow reading with racial minorities, it may lead to odd consequence if aliens of racial minorities can prevail in this kind of action while aliens of white majority may lose. We may not say if the outcome can be tolerated since the former are doubled as discrete and insular to the latter. This would still be true although the judicial business on human rights essentially operates to protect a discrete and insular minority from the political majority.

\section{Three Cases in Evolution and Over History}

As the progress was inflamed with the economic and political dissension, the Dred Scott v. Sandford, would be a landmark decision by the U.S. Supreme Court (1857). The court ruled that the African slaves could not become the citizen of United States, and hence were not entitled to claim his right in the federal court. According to the court ruling, the state is only authority to regulate the slaves, who would be the kind of labor element like commodities, not the holders of civil right, to the interest of owners. Over the long wake of dissension between the federalism and anti-federalism, the incident for an African slave to sue for his freedom in the federal court would be an exciting touchstone between the North Republicans and Sothern states (Dred Scott's fight for freedom, 2015). It is a controversial event preceding the American civil war, and might be seen as the kind of political contingency on then Democrat President Buchannan's dubious support to the southern states. Since Stephen A Douglas ended up supporting the popular democracy and opposed the decision, sectional interests would facially have no relevance to determine the justice of slavery. Dred Scott argued that his time spent in a free state entitled him to emancipation, but Chief Justice R. B. Taney, a staunch supporter of slavery, disagreed. The Dred Scott decision incensed abolitionists and heightened North-South tensions, leading to the election of Lincoln and the civil war (2015). The anti-slavery advocates and liberal legendaries often consider Taney as a satanic figure, and the case remains one of noisy constitutional and historical debate. Most contemporary lawyers may attribute the decision as mere dictum and no binding effect. In his argument in the federal courts, Scott had claimed that he and the case's defendant (Mrs. Emerson's brother, John Sanford, who lived in New York) were citizens from different states. The main issue remains to decide, therefore, whether it had jurisdiction to try the case and whether Scott was indeed a citizen (2015). As the Supreme Court denied a 
federal jurisdiction over the dispute and denied the citizenship of United States, the only protection could be available from the free states. It is unclear, however, why Scott and his wife had bypassed a chance to claim his free status in Wisconsin territory (2015). The case opened up ever most controversies of nation, at least in the equal protection of law, which had retrenched through a level of governments thereafter and the dilemma on the society of congruence. It also reveals a square aspect of factors to step into the issue of human rights, interdisciplinary indeed, i.e., political, economic and institutional or normative conditions of society as well as civility.

In Plessy v. Ferguson, the Supreme Court upheld a landmark frame of constitutional awareness, what we call the doctrine of separate but equal, involving the racial discrimination and equal protection of laws under the Fourteenth Amendment (1896). In 1890, the state of Louisiana passed a law, called the Separate Car Act that required separate accommodations for blacks and whites on railroads, including separate railway cars. Homer Plessy, a man of mixed race, was born a free man, but under Louisiana law, classified as black, which required him to sit in the "colored" car.

Plessy's lawyers argued that the state law which required east Louisiana railroad to segregate trains had denied him his rights under the $13^{\text {th }}$ and $14^{\text {th }}$ amendments, mandating the equal treatment under the law. The lower court ruled the state had the right to regulate railroad companies while they operated within state boundaries. Plessy was convicted and sentenced to pay a \$25 fine (1896). Plessy immediately sought a writ of prohibition. The Court ruled that a state law that "implies merely a legal distinction" between whites and blacks did not conflict with the 13th and14th Amendments. Restrictive legislation based on race continued following the Plessy decision, and its reasoning had not been overturned until Brown v. Board of Education of Topeka in 1954. While Justice Brown viewed segregation does not in itself constitute unlawful discrimination, he noted that "in the nature of things it could not have been intended to abolish distinctions based upon color, or to enforce social, as distinguished from political equality, or a commingling of the two races unsatisfactory to either (1896)." The "separate but equal" doctrine was quickly extended to cover many areas of public life, such as restaurants, theaters, restrooms, and public schools, and affected the federal, state and local policy making. However, many critiques agree that the doctrine was a fiction, as facilities for blacks were always inferior to those for whites. This may fuel the subsequent controversies and brought such kind of legal theories, say, critical or critical race theory into a due place of social understanding.

In Brown v. Board of Education, the Court, overturning the Plessy decision, declared state laws establishing separate public schools for black and white students to be unconstitutional (1954). The decision was reached unanimously by the Warren Court's, which held in its gist, "Segregation of white and Negro children in the public schools of a State solely on the basis of race, pursuant to state laws permitting or requiring such segregation, denies to Negro children the equal protection of the laws guaranteed by the Fourteenth Amendment -- even though the physical facilities and other 'tangible' factors of white and Negro schools may be equal pp. 486-496 (1954)."

The case was actually the name given to five separate cases that were heard by the U.S. Supreme Court, and Thurgood Marshall and the NAACP Legal Defense and Education Fund handled these cases (1954). The case shows an extensive debate on education and sociological ways of approach. Social scientist Kenneth Clark, for example, argued that 
"segregated school systems had a tendency to make black children feel inferior to white children, and thus such a system should not be legally permissible." The Court, then, was asked to answer whether separate school systems for blacks and whites were inherently unequal, and thus violate the "equal protection clause" of the Fourteenth Amendment to the U.S. Constitution, in other words, if the black and white schools were "substantially" equal to each other, as the lower courts had found? Based upon the psychological studies showing black girls in segregated schools had low racial self-esteem, the Court concluded that such system of separating children on the basis of race in the public school could not be sustained (1954). The similar lawsuits ensued and in the Brown II case decided a year later, the Court ordered the states to integrate their schools "with all deliberate speed." The opposing activists to Brown I and II had been seriously disgruntled with the Cooper v. Aaron (1958), when the Court ruled that states were constitutionally required to implement the Supreme Court's integration orders. While a widespread racial integration of the South was achieved by the late 1960s and 1970s, the principle had a spillover effect onto other area of public lives. Although the case is lately coming, public believes that that it constituted a watershed moment in the struggle against racial discrimination in America, and brought many changes in terms of federal, state and local public policies. However, there would be some views from originalists, such as R. Berger and M. McConnell, critiquing that the Court rulings cannot be defended by reference to the original understanding of the $14^{\text {th }}$ amendment or that the decision is the product of radical reconstructionists who spearheaded the 14th Amendment were in favor of desegregated southern schools.

\section{Implications through the Affirmative Action}

The racial issues involve a typical of American society, and perhaps as unique that still have a potential to be inflamed. It has a basic socio-cultural implication as well as political and economic strands in perspective.

First, race issues represent the multiculturalism of United States besides any other trait of classification, such as aliens, ethnicity and age. The context of struggle or contention is distinct while many other jurisdictions, in terms of comparative view, generally would not come salient with race issues (Feagin, J.R., Feagin B.R., 2007). Rather, their socio-cultural agenda for pluralistic society or equal protection of laws, if disputed ever, would be concerned of other elements, such as ethnicity in Russia, China and eastern Europe or aliens in recent Korea, as well as isolate indigents in Japan. That is because the new Republic in this land required a slave labor to exploit such vast of uncultivated land, and the defeat of European imperialism had turned to relate with the trade of African slaves in any dehumanized way. Hence, the current controversy would not be mere of socio-cultural divergences, but also can be connoted with the political or economic history of nation. In Europe, the Muslim immigrants had surged to complicate the harmony of nations over the past years whose issue is ambiguous, perhaps needed to be distinguished, since the immigrants are voluntary and the strand of discrimination in Europe is rather religious or ethnic than racial. The issues in Europe would mirror a current of US dilemma in terms of its voluntariness, involving the national immigration policy and especially those of Hispanic origin over years (2007). Although the civilization and democratization preceded in Europe, their perception and standard or social practice would be same as to despise the colored people at least until the French declaration of rights of man, which was, on its face, of universal character, and some years later at the advent of US Constitution. Despite the sublime pronouncement along with the bill of rights in England, the nobility and new class of wealthier people generally would be structured with the prevailing ethos of bourgeois, 
meaning a class consciousness and social practice on discrimination. The kind of three estates, namely bishops or clergyman, nobility and third tier of in-castle residents, such as successful merchants, lawyer, medical doctors, had left a repercussion over the significant period time. While we see the medieval practice of feudal relations, a local potent would be any same peer with the King in cases whose trait would not be totally absent in some kind of barbarian land around early of independence age. The interest or structure of states would be diverse or characteristic in terms of important aspects of states. Some states even could not manage if the servitude and exploitation were to be denied as a matter of constitutional principle (2007). Then we may ask why the servitude or inhumane practice of society could be tolerated long period of time until the civil war? Most importantly, we can find some clues from the constitutional history of nation. The US constitution is a federal law concerning how to organize the government, hence, the separation of powers principle and federalism to regulate the relations between the federal and state governments (Vile, J.R., 2010). The original ten set of individual rights also imposed an obligation of federal government to protect the basic and classic rights of man, which never could be applied to the states. The states could go their own way at least in terms of important state policy areas, such as political, economic and civil rights unless it would not infringe with the federal interest or selected scope of federally enumerated national issues. While a growing ethos of universal human rights would inculcate the national politics especially within the northern industrialized states, the confrontation had naturally been fueled into the civil war. Along with several other amendments, the Fourteenth Amendment required the states to be limited with the core of civil rights, i.e., life and liberty on the due process of law as well as equal protection of laws (2010). We may recall on the intrinsic of US federalism where the civil issues are inherently within the state jurisdiction until those amendments were placed in order. The original bill of rights, as we hint from the Constitution, matters, mostly in nature and operation, with the kind of public system and political institution interwoven with the fundamental freedom, such as freedom of expression, assembly and religion, jury trial in civil and criminal adjudication, search and seizure, and the kinds. While the scope of rights was idealistic and essential to emancipate people from the arbitrary governmental power, its national reach would be selective and highly retracted varying with the state practice. Additionally, most of substantial aspect of civil life remained within the need and discretion of states. This historical wake would be a good point of comparison for the $20^{\text {th }}$ new born republics who imported a nationally complete form of democracy and civilian rules from the US, which would be the kind of experimental lab or classroom on the thought of how the real politics, economic relations, and different trait of civil society could struggle toward any idealistic structure of society (Feagin, J.R., Feagin B.R., 2007). This also can be said of European states although it originated the concept of human rights, since the dynamic progress over history between the state and individual rights could be charted in view of the realism or pragmatism. On the other hand, federalism also would be any powerful strand to make the progress resilient, but fairly pragmatic in the contest of humanity, public utility or diversity interests of society. That can be implied already earlier as if the famous words by earlier justice, "....we have a constitution of color blind," would teach, but such pronouncement is still contended how we construct any better system to accomplish a practically best effect from the "separate but equal" through "desegregation thesis." I also may add that the affirmative action most closely reflects a political and economic nature of justice that "past wrong" must not only be abolished, but also redeemed to restore a balance of justice.

In this line of consequence, it would not be inadequate that we perceived three highlights to pertain to the essence of racial issue. Dred Scott would divulge an econopolitical dissension of two governments and Plessy would be related with such quagmire of 
social incongruence. The Brown would invent new perspectives on the social congruence and integrity of nation in the face of racial challenges. 


\section{Reference}

Brown v. Board of Education of Topeka, 347 U.S. $\underline{483}$ (1954),

Brown v. Board of Education (1954)

http://www.pbs.org/wnet/supremecourt/rights/landmark_brown.html.

Cooper v. Aaron, 358 U.S. 1 (1958),

Dittmer, R. (2013). Incorporation and the "Liberty Clause" of the Fourteenth Amendment, New York. NY: CreateSpace Independent Publishing Platform.

Dred Scott v. Sandford, 60 U.S. $\underline{393}$ (1857),

Dred Scott's fight for freedom (2015). Retrieved Mar. 27, 2015 from http://www.pbs.org/wgbh/aia/part4/4p2932.html.

Kim, Kiyoung, Human Rights: Are They Just a Tweak for the Policy Makers or Administrators? (March 3, 2015). European Academic Research, Vol. II, Issue 6, September 2014. Available at SSRN: http://ssrn.com/abstract=2572951

Plessy v. Ferguson (1896). http://www.pbs.org/wnet/jimcrow/stories_events_plessy.html.

Feagin, J.R., Feagin B.R. (2007). Racial and Ethnic Relations New York, NY: Prentice Hall.

Korematsu v. United States, 323 U.S. 214 (1944).

Nelson, W. (1998). The Fourteenth Amendment: From Political Principle to Judicial Doctrine, Boston. MA : Harvard University Press.

Plessy v. Ferguson, 163 U.S. 537 (1896),

Stern, S.J. \& Straus, S. (2014). The Human Rights Paradox: Universality and Its Discontents, Madison. WI: University of Wisconsin Press.

Sugarman v. Dougall, 413 U.S. 634 (1973).

Vile, J. R., \& Menez, J. F. (2010). Essential Supreme Court decisions: Summaries of leading cases in U.S. constitutional law. Lanham, Md: Rowman \& Littlefield Publishers. 


\section{The First Amendment Right}

\section{On the Public Media and Freedom of Expression}

The government has a need to regulate the newspaper which would seek a public order and morals in the nation. The concerned intellectuals and conscientious citizen might be peevish about the lack of pertinent statutes concerning a misappropriation or bias from the newspaper establishments. The kind of business would lead to the constitutional debate as to tackle with many important points of law and public policy. The crusty old readers may get irritable on the misleading articles or false stories, and young activists may be perspicacious to dispute its legitimacy on the freedom of expression or its constitutional limitations on it. They may bring the controversy on the ground that infringes with the right to dissent or to claim a correctional announcement. The federal statute pertaining to the authority or responsibility of "FCC" may not deal with the questions given the newspaper is not such media onto being aired, but print-based. The commerce clause may be invoked to authorize the constitutional competence of Congress, but the regulatory measure would be a piecemeal or blurted out contingently to respond perhaps with imposing incidents of public challenge. It implies that the federal response would be less systemic unlike the regulation of broadcasting media or internet providers. Provided if the regulation of newspaper is little on implications or ambit of interstate commerce, the state government would be a principal authority to deal with the requirements or public duties of newspaper commercials.

The freedom of expression would be one of most popular constitutional basis of judicial review principally because the human agent possesses the kind of intrinsic or attribute to convey ideas and thoughts (Brown, 2013; McGonagle \& Doners, 2015; TI, 1970). The ideas or thoughts would be classed between the facts and opinion, both of which are important in view of modern politics on freedom and democracy. The distinction, per se, would not be a constitutional frame of approach, but could be implicated with the refined context of operation, such as civil liability or constitutional torts, freedom of press and mass media, sorts of speech and content-based regulation, and so. The governmental regulation, hence, could well be investigated arguing if the citizens on free expression could not bend if with unduly designed or impermissible nature of public regulation. This interplay, routinely over the course of our public lives, actually brings a thesaurus of case law preserve on the freedom of expression. The context had multiplied to face with such remarkable progress of cyber space communication over the period of time

The freedom of expression guarantees the development of self in the community, essentially prerequisite to the liberty and emancipation from the censure-ship or oppression of established order $(2013 ; 2015 ; 1970)$. The kinds of public authority, say, religion or tyranny, had been contested earlier in the inchoate ideals, and the state would constantly be challenged if to ensure a liberty to develop the self. It entails the spirit and cause of enlightenment and such practice of prior restraint had been condemned to create public conditions for a free flow of ideas in the market.

The freedom of expression lays a foundation for the democratic form of government. The ideas could be unabridged to support the basis of political cause or activity, and participatory democracy can be evangelized as with the right of free assembly and association $(2013 ; 2015 ; 1970)$. It would contribute to a sound political opinion and viewpoints shifting a political majority and so as not to perpetuate the power in reign. The free competition of 
market would ensure an equal opportunity to shape the paradigm of fair play. Since it essentially is related with the public lives and national politics, the Court would dose a different level of scrutiny between the commercial speech and political expression (Vile \& Menez, 2010). Nevertheless, the content-based regulation would deserve a stringent standard of scrutiny since the government shall be expected to perform their responsibility as a neutral administrator of market. This requirement also stems from an inherent suspicion if the government could be prejudiced to favor or disfavor a specific nature of expression. The content neutral regulation is considered less suspicious and normally deemed more proper with the limited paradigm of government or neutral administration that the court would invent a generous rule based on the time, place and manner regulation.

The freedom of expression is not an absolute right without limitations, although it can claim a privileged status so as to gear up with the liberal paradigm of modern government $(2013 ; 2015 ; 1970)$. A libel or defamatory statement would be one hyperbole often raised in the courtroom by the disputed parties (Hustler Magazine and Flynt v. Falwell, 485 U.S. 46 (1987). The doctrine of public figure or public officer had evolved over time to permit a permissible tolerance on the scope person on one hand, and the Court, on the other, articulated a due scope of constitutional mandate as termed a constitutional tort. In this nature of concern has the legal approach been conspicuous in terms of debating structure and intervention of Constitution to effect within the area of civil remedies. The state action theory would enlarge the scope of norm receivers and the constitutional tort would apply as a crucial standard in evaluating and determining the elements of tort liability.

The freedom of expression would begin to interact with a heightened institution of nation so that press or broadcasting media turned to profile as a key subject matter of nation. The impact of expression in this case generally would be wide, systemic, profound or unilateral that the need and frame of regulation, for some circle, may phase desirably with a distinct response. The existing laws in terms of national regulation allegedly have flaws that shall be reviewed as of its constitutionality $(2013 ; 2015 ; 1970)$. The policy area on newspaper regulation needs to be recast in reflection with the views and philosophy above addressed.

First, the press would employ a number of expressers that the development of self could be complicated between the corporate and individual reporters or editors. Hence the internal dispute also requires the kind of public policy between the role and responsibility of editors or reporters and commercial nature of corporation. Also between the reporters and editors, some workable and publicly effective standard of work authority or division need to be dealt in the process of legislative deliberation. Under this structure of private or public interest, the kind of thought, though from the international law case, may be predicated if we legitimately impose erga omnes or abuse of rights as espoused in Barcelona Traction co. by Padilla Nervo J. This suggestion presumes if the press could inflict a much extent of public harm in the cause of corporation's interest or bias a free flow of ideas. Hence, the relationship among interested parties could be spelled out duly by the government authority.

Second, the right of dissent or to corrective announcement would be an element that shall not be dismissed. The impact of press or newspaper in my case is serious necessitating a minimum level of haven to restore the balance of justice among interested parties although the press is a key institution of democratic state and commercially purported as free of any coerced expression. Given its commercial status, the dispute among interested parties has to be an issue of civil action and damages. Nevertheless, it would come more proper that the 
state intervenes to create a system between the commercial establishments of press and their public responsibility. Precisely because the newspaper performs an important function to stimulate and formulate or even develop the public opinion, it would be regarded as the kind of fourth branch and important public avenue to sustain the democracy of nation. This impels an untainted guarantee of free expression on one hand, and the state, on the while, needs to provide a public system from possibly an abusive use of institution.

\section{A Brief of Korean Controversy and Views}

The first issue would be to determine if the state can ordain the public responsibility of newspaper as a matter of principle within the statute (Act of Press Advancement, 2014; Korean Constitution Court, 2006).

One view asserts that a radio or television broadcasting differs from newspaper in terms of its element and basic purpose and abridges an equal protection of law. It also stresses the importance of pluralistic press in the society and neutrality principle of national administration that the Act transgressed the freedom of press and constitutional theory of Tandenzschutz. A countervailing argument may stand that the clause of statute would be abstract and declaratory without no specific binding power, and could frontier the right of consumer and was designed to protect the integrity of personhood that could be substantiated with the compilation of case laws. The Act also provides a reporting requirement containing the business records and information, which is compulsory and shall be filed with the Press Advancement Commission (2006; 2014). A critique of the Act would argue it is unduly discriminatory against the newspaper companies, hence, fallible to contravene the equal protection of laws with other nature of businesses. It has a chilling effect since the reporting requirement mandated details of information, such as shareholder's and even employees'. This necessarily brings a possible reduction of investment and collapse of material condition against the opposing newspaper companies. Proponents of the Act would counter that the clause was intended to ensure the transparency of newspaper enterprises, and designed to prevent an excessive competition by impermissible means. The scope of information mandated to disclose is lawfully purposive to enforce other provisions, such as assessment of monopoly status and due supervision of management. It also facilitates the right of consumer to informed decision and that of advertisement subscribers. The Act prescribed the right of editors enjoying independence from owners of press $(2006 ; 2014)$. The dissenters of this clause emphasize the classic virtue that the right to edit shall fall exclusively within the authority of press owner. It is unconstitutional to statutorily safeguard the autonomy of editors or employees in the editorial process and decision. The advocates on this clause would defend that the articulation of legislators should sustain since it upholds a crucial aspect of first amendment right. They asserted that it constitutionally ordains the kind of subsequent development in the area of First Amendment jurisprudence, such as freedom of editing right, independence between the management and editors, proscription of impermissible intervention on the editing process and decision, autonomy of press editors, and public duty of owners and managers to protect the professional activities of editors or writers (2006). This view and reality in Korea, however, would be in some contrast if the usual dealings of US constitutional case materials treat the issue as additional.

\section{A Prospect of Evolution}


A controversy briefed thus far had been developed in the actual setting involved with the constitutional litigation in Korea. The Act of Press Advancement enacted in 2014 was squarely challenged that the petitioners claimed the unconstitutionality of clauses covering Art. 3 (2), 3 (3), 4, 5, 6 (3), 8, 15 (2), 15 (3), 16, 17, 18, 39 (i), 40 (iii), 42, 43 (1) (iv) (2014). One other act was consolidated as subject matter entitled the Arbitration Act of Press. In the above, I have excerpted part of arguments, criticism and propositions raised through the section of Amicus Curiae. Interestingly, the controversy centered on the basic relationship between owners and editors or other interested group. This implies basically if the important state philosophy can be a governing factor and that the Court shall identify a due extent of public intervention with the classic liberty on property. I am not sure if the same kind of state or federal statutes can survive a constitutional muster in the United States. The line of cases in regulating the Press to improve the marketplace of ideas would be limited in deals, which cover the right to gather information or access to the court proceedings for reporting work, as well as federal regulation on radio and television broadcasters by FCC. In Tornillo, the Court considered the right of reply statute of Florida to protect the political candidates against attack of newspaper medias, and ruled to invalidate the statute, stating "government enforced right of access inescapably dampens the vigor and limits the variety of public debate (Miami Herald Publishing Co. v. Tornillo, 1974)."

Although not a print media, the Court upheld the ambit of federal purpose in Red Lion, which repudiated a challenge against the FCC's fairness doctrine and its component regulations governing personal attacks and political editorializing (Red Lion Broadcasting Co. v. FCC, 1969).

The Court reasoned, "even where there are gaps in spectrum utilization, the fact remains that existing broadcasters have often attained their present position because of their initial government selection in competition with others before new technological advances opened new opportunities for further uses. In view of comparative judicial style, I may derive two aspects distinct from Korea or other countries of public or social legalism. First, the Court based their logical process on the give and take metaphor, although the issue may be authored from the side of public or social cause. Second, the legal realism may influence to conceive elements of free expression or public media in view of the marketplace of ideas, which generally would be strongly anchored within the thought of American legal realism. Besides other several cases, I may comment on the prospect of media policy from some of basics. First, the subject matter may be captured within the province of state government, which, however, likely increases the chance to be endorsed in the federal litigation. That is because the doctrine of selective incorporation could deny an allegation of first amendment rights or make the Court be tempted to defer to the state discretion. Second, the federalism would be prone to allow a scope of leniency in regulating their businesses and industries other than interstate commerce. Third, the regulatory measure would not be a content-based, instead, content neutral so that the Court would apply a mild standard, such as the rule of time, place and manner restriction, which could lead to the finding that the Act would be sustained. The clear and present rule or other stringent standards will likely not be employed, which is unlike the cases involved with anti-sedition act, criminal advocacy of communism, libelous statement or others (Dennis v. United States, 1951).

Fourth, the federal intervention, seemingly if least on the ground of Commerce clause, may be embraced, which, in that case, could be vociferous involving the basic ethos of community between active regulation and laissez faire or deference to the states. This 
would differ if the Korean Constitutional Court had supported legislations, which is unlikely to be such easy in the US case.

\section{On the Freedom of Religion}

\section{The Scope and Rationale}

The correctional bureau of countries would administer a policy to affect the constitutional rights of prisoner. The prisoner is situated in particular conditions since he or she would be incriminated and housed in the confined area as a matter of criminal justice within the state or nation. It would be bound by the constitution, federal and state laws, and would create or implement the rule relating with the exercise of their statutory responsibility. Korea and US have a same berth of constitutional provision dictating the constitutional relationship between the state and church or religion (Kim, 2015). Since Madison's landmark "memorial and Remonstrance, outlining the logic against establishment, involving the Henry's bill in pre-revolutionary America," the public power, as typified with the general applicability of law, had to clarify any respective status of both within the political community (Perry, 2006). First, the tread to induce mores or social norms could help us on the quality and nature of controversy. The public power generally hinges on the religious belief, morals or social custom in its inception. Riding off a horse on the terrain of conquered land, it is natural that the rule shall be pacified in any of those normative bases. They are an inchoate form of ruling standard to serve the political power that can, over time, be civilized into any intricacies of written or unwritten law. Given the American revolution is foundational, debate on the First amendment would progress to touch on the inherent sphere of fundamental disposition between the state and civil dimension (Vile \& Menez, 2010; 2006). It is much implicating since the provision had exerted a global reach for the postcolonial Republics. Second, the medieval history through enlightenment philosophy as well as protestant revolution against old communion of Roman Catholic had strained leading a foundational thought waked with $\mathrm{T}$. Jefferson and Madison. A religious belief generally would be any fairly powerful factor to define an individual, community and even nation. It can still be exemplary with Thailand, Tibet, negatively with Muslim states and worse with the quasi-religious quality of communist dictatorship. Importantly in the colonial states, the power of church would be not only symbolic, but also a practical avenue to magnify the British rule in the new land (2006). The protestant venturists had been overwhelmed from the prevailing influence of National Church in mainland of England on one hand, and could be agreeable since the concern and dimension would be religious on the other. The situation gradually could attain a stigma with an increasing fantasia for the independent nation that new Republic had to truly be a liberal state emancipated from any prior structure of public power. The identity of new nation had been shaped more starkly with the Establishment clause, free exercise of religion and freedom of expression (2006; Separation of Church and State, 2105).

Then we can be assumed that two victories had been settled in understanding the modern liberal constitutionalism.

First, the liberty or liberation was realized from any shackling of existing authority or ancient regime, such against the state or religion (Brown, 2013; McGonagle \& Doners, 2015; TI, 1970). A mightier King to derelict the Catholic or authority of National Church as well as Catholic itself and further new Republics themselves could not derogate the freedom of individual in the deep dimension of his spirit or conscience. In the interplay, we can identify two directions of idea as feared if to frustrate the ambition of new Republic, to say, Roger 
Williams who feared state corruption of church and $\mathrm{T}$, Jefferson who feared church corruption of state. At that time, the restraint on expression may largely come from religious orthodoxy and the state power exerted to control an essential domain of individual freedom by placing a prior restraint. The three pillars of First Amendment, therefore, deal in the same ambit to alter ancien regime and oppressive institutions, meaning to revolutionize. Second, the Constitution affirms the superiority of state power in any civilized approach that liberated the church on the other hand $(2013 ; 2015 ; 1970)$. The vague nature of cohabitation between the state and religion was altered to give a clear status with a vehement and caustic errand for the liberty and equality of new class. Again, oppression and discrimination had been a most hated evil that should be squelched for a comforted class of new land.

\section{Court Frames and Rulings}

The thoughts above generally brings if the First Amendment is absolute and fundamental on one hand, and can have a due limit from the public interest $(2013 ; 2015$; 1970). Therefore, the judicial standard on the clear and present danger rule would provide a certainty involving the criminal statute, such as anti-sedition act and criminal syndicalism. The attribute on this rule generally affirms its central importance as a principle of foundation in terms of Republican concept and liberty of citizen on deep dimension of personality (Vile $\&$ Menez, 2010). The issue of conscientious objector is also another example that the Court would respect more profoundly the spiritual liberty of people. Since Korea has not serious religious history upon the demise of Lee dynasty in 1910 and national liberation in 1945, the Constitution provides an independent clause on the freedom of conscience unlike a unitary dealing of free religion in the US. A practical difference would be little, but the gamut of applicability is comprehensive, at least, in a linguistic sense, that conscientious objectors may not prove a nexus with religion or people may be safeguarded from a compulsory revelation of his sexual orientation, such as gay or lesbian, in the process of state affairs. One hottest issue involving this clause over the constitutional history of Korea would be if the communism could freely be spawned or developed inside the spiritual dimension of people. For example, the kind of issue has been considered if he or she can lawfully possess the prints of communist advocacy although he or she had not expressed or acted?

The public power would intervene possibly at extent in the course of exercising the constitutional power although the disestablishment had been principled. We may share a solution with the three part test affirmed in Lemon v. Kurtzman (1971), which requires (i) "valid laws on the subject have a clear secular purpose, have the primary effect of neither advancing nor inhibiting religion, and avoid excessive entanglement between church and states."

The standard of judicial scrutiny could often requires a compelling state interest whose terms tend generally be employed exercising the strict scrutiny. It was established in Sherbert (1963), and was named the Sherbert test, which was limited in the subsequent cases, City of Boerne v. Flores (1997) and Gonzales v. O Centro Espírita Beneficente União do Vegetal, (2006). The majority authored by Justice Brennan, while dismissing the claim that the Court established the Seventh Day Adventist Church, ruled "denial of Sherbert's unemployment claim represented a substantial burden upon her" who was lost of her job because of her faith (1963). He also enunciated, "to condition the availability of benefits upon this appellant's willingness to violate a cardinal principle of her religious faith effectively penalizes the free exercise of her constitutional liberties (1963)." There were two concurring 
opinions sustaining the lower court judgment and one dissent from Justice Harlan. From the rule, the judicial test requires that public interventions can only survive the constitutional muster as satisfactory with two prongs test, say, the compelling state interest prong and the narrowly tailored prong. In the latter prong, no alternative form of regulation could be feasible but with such infringement in achieving the state's end. One other popular issue involving free exercise of religion would be a school prayer, in which the public schools are banned from conducting religious observances such as prayer (Schemo, 2001). This view is firmly ascertained through the court cases and around the turning point with such cases as "Regents` Prayer" and Engel v. Vitale. While two basic perspectives between the fundamental adherents on Judeo Christianity and religious diversity or freedom of religion supporters as T. Jefferson exist in the country, the nature of religious controversies in the US seems generally settled that the state allows everyone the freedom to practice their own beliefs and that the United States has a strong history of First Amendment.

In the City of Boerne, the Court had not be firm to respect the rule of prior case that authorized an extent of leniency with the kind of logic and rhetoric on balancing test (1963). Given the establishment clause is foundational and interwoven essentially with the political philosophy or structure of federal union, the standard would logically be stringent availing of the kind of strict scrutiny. That is because the judiciary would be one of three separate branches in terms of national politics, which impels a due of worship for the foundation of nation preferably precluding a less standard of scrutiny. The lesser test, such as balancing one, would be adequate in some cases, if least involved with the separation of nation and church, such as "theory of special conditions and less on general applicability of law," although the free exercise of religion arises since the state power is the kind of ultimate authority to create the general applicability of law over other social norms or people on such adherence. Hence I suppose that the approach and basic purview depend on the circumstances and conditions of controversy. If equality among disputed parties were to be involved beyond the individual interest on religion or conscience, the standard of scrutiny could well be heightened.

In my case, prisoners under the custody of correctional bureaus argued that they are duly entitled to the constitutional liberty to pay memorial on the religious event they believe. The Korean Constitutional Court, by applying the similar purpose of balancing test as US, ascertained their claim positively that struck down the prison regulations and ensured their constitutional liberty pronounced in the Art 20 (1) of Korean Constitution. The probable consequence in the US frame would be dubious if the kind of group could be disposed in any same destiny assuming if the state has gone to place a similar restriction as Korea did (Associated Press, 2005). First, the federalism could restrain the plane in which Congress can play to require the state government to respect the First Amendment. As we see, the Fourteenth amendment operates as a legal instrumentality to impose the bill of rights as a duty of state government, what we term as selective incorporation. It is selective as held through precedents that Congress could be impeded from the nationalization of First Amendment and that the state could not be derogatory with abuse and neglect. The Religious Restoration Act would be contested from this viewpoint (Copeland, 2003).

\section{A Case, Legal Theory and Public Policy}

The Constitutional Court of Korea ruled in 2014, that the prison regulation to forbid detainees pending to the court proceedings or of undesignated status for additional crimes (DPUS) from participating at a weekly ritual of believers had impermissibly interfered with 
his free exercise of religion. The defendant, prison authority of nation, has provided regularly, three of four times a month, the religious event for the detainees of established status scheduled to prison work, but once a month for DPUS (Korean Constitutional Court, 2014). The latter arrangement became obsolete and unobserved due to limited space and scanty workforce to manage the events, which could practically be held only once a year. In consideration of detention period for DPUS, such reality may well be interpreted as being stripped of religious freedom.

The Court had applied the traditional four-part test, which requires (i) a legitimacy of legislative objective, (ii) adequate means, (iii) least intervention to the individual liberty, and (iv) balance of public interest sought and harms incurred on the individual. Since Korea is a homogeneous quality of society, its constitutional theory would not borrow the kind of ideas, such as suspect classification or strict scrutiny (2014). The kind of dual standards in review involving the first amendment or deep nature of specificities in framing a Court ruling would also not be stark although the CKK put a general emphasis on its central importance in the constitutional practice of nation. The judicial style is therefore formalistic, and can only be buttressed with substantiation varying with the disputes and content of legislation, which, however, is other than such dichotomies, i.e., privileged v. normal right, content neutral v. content based, political v. commercial and so. On the first and second parts of test, the Court had found that the detention facilities or national prisons need to be managed with a stern regulation and for the internal order because it functions to coerce a criminal purpose by detaining criminals or accused for a certain period of time (2014). A regulation to limit the free exercise of religion facially would be permissible as a legislative end and adequate means to ensure the safety of prison workforce and facilities as well as inmates. On the part of least intervention, the Court adduced that the religious activities of detainees is precious in terms of penitentiary purpose brining the effect of mind purification, reconstruction of moral consciousness, good livelihood, repentance, and stable service to the detention period (2014). In relation with DCUS, such opportunity facilitates an essential purpose of facilities' internal order and safety since his experience of sudden detention tends to arouse an emotional instability leading to mental failure or suicide. Given such strong policy needs on DPUS, the constitutional right on religious freedom has to be extended to cover them beyond the convicted detainees. This is presumed on the ways of regulation, while comprehensively captured as same status and indiscriminate between the convicted and DPUS within Art. 1 and Art. 45 of the National Prison Administration Act. According to the Court rule, the prison authority may enact a pertinent rule to distinguish between the convicted and DPUS. However, it furthers that the standing rule and practice impair the proportionality and balance of justice in view of gross disparity in the number of detainees (1/8 between two groups) and number of events monthly. The reality outnumbered by DPUS was used to serve a contrary purpose by reducing the turns of event at one time annually (2014). This depraved arrangement of religious event would disparage unconstitutionally free exercise of religion for DPUS, which shall be condemned despite the wane condition of Pusan prison facilities. There could the Court find a less restrictive alternative means which was simply and unconstitutionally bypassed by the prison authority (2014). Concerning the balance of public interest sought and harms incurred on the individual, the Court had found regulation or disposition of Pusan prison authority overbroad and excessive that should be declared unconstitutional (2014). This sweeping standard of review, often titled as "proportionality test" and lodged firmly and uniformly over the practice of Constitutional Court, would be similar with the strict scrutiny of Supreme Court in terms of rhetoric despite little difference in its frame. That seems because the US is a federal union that Supreme Court tends largely differ 
to the legislature, especially Congress, if availing a rational basis test or balance of interest test. An invalidation of acts almost always results when the Court would apply the strict scrutiny, which starkly implicates as emergent and urging in view of federal governance. That differs from Korean practice that the proportionality test would be equal on chance or regular course of reviewing standard, yet to affirm the legislations oftentimes.

The abuse of prison authority once had been doubted involving one state prison, Guantanamo detention camp, and in accomplishing so-called political justice in the national heat and passion against terrorism. The prison setting is exotic and very basic on human elements and public cause that could be a good classroom to contest the abuse of human rights. Unless otherwise any special context challenged, the state laws and regulations mostly govern to attain a public purpose of detention in US. I consider that the factors working through a review standard and probable outcome among both nations would have some structural differences, but can be set off to any same effect as mutatis mutandis.

First, Korea is unitary nation that the central and local governments are indifferent as a norm receiver meaning they are directly responsible to respect the constitutional mandate of religious freedom. Second, Korean constitutional and administrative law traditionally recognized the "theory of special conditions (gradually decreased as a judicial theory)" between the regulates and public agencies, which, as a matter of legal theory and as imported from German laws, enlarge the permissible extent of intervention in such cases, e.g., military men, students of public school, prison detainees and other some. On the other, the Supreme Court of US would not be certain that the Congress could enact such laws since it has narrow sense to interpret the Fourteenth Amendment by seeing it merely an enforcing authority and also is rooted on the theory of selective incorporation. Nevertheless, the standard of review involving free exercise of religion is firm by applying a rule of strict scrutiny. Furthermore, there would be no such "theory of special conditions" in US, which would be the kind of heritage serving administrative convenience in the age of imperialism, the kind of same legal institution as capitulation concerning foreign affairs. While the former would tighten the domestic order, the capitulation may go outward to arrange an institution in the end to exploit the subject lands. Whilst these differences operate, I expect that both nations may reach, in high chance, same conclusions that one day religious event annually could not be kept effective through the nations. That is probable although a religious demographic of nation has decreased in Korea and fiscal deficit was highly assailed to stress on its balance from the political circle within two nations. As the empirical findings of Supreme Court practice corroborates, the Supreme Court and Constitutional Court of Korea are generally true to dispose highly on normative basis than political consideration of issues, which little differs from the state or lower courts and administrative agencies. 


\section{Reference}

Act of Press Advancement (2014). K. Stat. No. 12408.

Brown, J. (2013). Freedom of Expression New York. NY: Amazon Digital Services, Inc.

Dennis v. United States. 341 U.S. 494 (1951).

Gonzales v. O Centro Espirita Beneficente Uniao do Vegetal, 546 U.S. 418 (2006),

Korean Constitutional Court. 2012 Hun-Ma 782 (2014).

Hustler Magazine and Flynt v. Falwell, 485 U.S. 46 (1987).

Kim, Kiyoung, Human Rights: Are They Just a Tweak for the Policy Makers or Administrators? (March 3, 2015). European Academic Research, Vol. II, Issue 6, September 2014. Available at SSRN: http://ssrn.com/abstract=2572951

Korean Constitution Court. 2005 Hun-Ma 65·314·555·807 (2006).

Lemon v. Kurtzman, 403 U.S. 602 (1971).

Miami Herald Publishing Co. v. Tornillo, 418 U.S. 241 (1974).

McGonagle, T. \& Doners, Y. (2015).The United Nations and Freedom of Expression and Information: Critical Perspectives. Cambridge. UK: Cambridge University Press.

Red Lion Broadcasting Co. v. FCC. 395 U.S. 367 (1969).

Shneider v. State, 308 U.S. 147 (1939).

TI, E (1970). System of Freedom of Expression. New York. NY: Random House.

Vile, J. R., \& Menez, J. F. (2010). Essential Supreme Court decisions: Summaries of leading cases in U.S. constitutional law. Lanham, Md: Rowman \& Littlefield Publishers. 


\section{The Constitution and Foreign Relations}

\section{Overview}

The federal government uniquely would be assigned constitutionally with the power of foreign policy. It would be a separate issue if the federal government can negotiate and conclude the treaty to allow a diplomatic nature of jurisdiction to the state government. For example, the government procurement in terms of free trade regime may be negotiated to include the state government as one of actors that is bound by such nature of international treaty, which possibly raises a constitutional controversy on the Eleventh Amendment or federalism. If permissible, the kind of act, say, Buy American Act, could not be enacted since it breaches such WTO treaty to impose the free trade regulation on the state government. The issue of foreign policy or treaty obligations also ushers in the kind of debate on deliberative democracy and democratic control of Congress. That is because a plenipotentiary or negotiating diplomat exercises the kind of creative power as similar to the authority of Congress, nevertheless, is curtailed of a vast of legislative process pivoted on the principle of democracy (Vile \& Menez, 2010). The Court would be a least dangerous branch to entertain the power of judicial review, but has inherent limitations on the area of foreign policy. Most importantly, the structural limitations would be present that the separation of powers principle or justiceability effectively impedes its active role from judicial control of foreign policy. There would be other factors to describe the extent and propriety of Court intervention in the area of foreign policy, (i) the quality of issue (ii) legal theory on the international laws held by the Court itself (iii) philosophy and national ethics. Let me firstly brief the structural limitations, legal theory, and philosophy and national ethics, which would wield a general influence on the Court attitude as a retracting factor in intervening with the policy making of foreign affairs.

\section{Doctrines, Inherent Limitations and Philosophy}

The Separation of powers principle had been designed in the intention to protect the interest of new wealthier class, most shared and perhaps revolutionarily. In this cause and under the title of human rights, it was generally viewed indispensable and urgent of institutional forge with the Constitution of new Republic (2010). It had a secondary purpose to ensure the concept of "workable government" by checking on the encroachments from other coordinate branch in the exercise of their distributed power. Hence, the principle entails a characteristic on the hard face of organizational division concerning constitutional powers and responsibility, and assumed that the creators of constitutional law is most sagacious to assign a proper role within each separate branch. Given the discourse on legal stability and predictability, the laws is the kind of machinery lighting the right path of practice or activities for the norm receiver and allowing them to avoid any wrong way to falter with a social or public disutility. It is expected and shall be in that quality surely that can create the stable and predictable conditions of normative-usually political-community, in which the interested parties come in enlightenment as well as vested to improve and progress. In this way, the law can be a crucial instrumentality that the individuals and society are able to evolve.

The constitutional law dictates the public officers to obey their constitutional obligation, but is spelled out never enough in considerable instances, especially in the area of foreign policy and wars (2010). As a frontier of state issues, the nature of involvement may 
be more properly framed in terms of strategy-war responsiveness in case of war situationsother than the peacetime values.

The Court has a constraint since its power is constitutionally predicated on the case or controversy requirement. The legal theory would only grant its basis of jurisdiction that specific harms or loss is judicially identified, what we call a justiceability. The theory, then, would delineate the kinds of legal doctrine, ripeness, mootness and standing. Hence, the condition for judicial power as matter of constitutional separation requires an enhanced concept of interested parties, very tightened and as judicially enriched on its frame and identification. In terms of "interested" parties, the kinds of interest, for instance, "scholarly, abstract or public" could generally disqualify in meeting judicial intricacies on the standing. From this understanding, the environmental group held around a least chance to dispute with EPA or other interested parties in the courtroom. And the congressman would fail to argue on the authority of unilateral action of President to terminate the treaties with Taiwan in 1970's given his or her interest would merely be "public" arising from his constitutional duty (Goldwater v. Carter, 1979).

The internationalist or transnationalist approach would be received as a disloyalty of public officer, who could possibly invite a rancorous reaction from Republicans (Cohen, 2006). That enjoys a nationwide repercussion although it is no seldom to recognize the idealistic institution or public utility within the international laws and the global society becomes more sharing or to see an interaction with the states of porous border. From the Hobbesian thoughts on social contract and absolute power of sovereign, we would highly be sympathetic that the public officers shall be a "fiduciary and entrustment" to keep the contract exchanged for mutual prosperity in forming a democratic government. His idea and basic adherence enabled a dualism between the national and international laws, impacting seriously the politics of Anglican countries. Therefore, it is no surprise that the Courts of US would not enforce the international customary laws as a binding law. A presumption of nonenforceability on the international treaties would generally be prevailing unless it has transformed into domestic law, such as US laws on the implementation of WTO Conventions. The presumption could only be countervailed if the treaty contains an enforceable quality of detailed provisions, perhaps looking any well-drafted contract by prestigious law firms, or conclusive evidence reduced into writing by the plenipotentiary or president. Hence it seems more sensible to the Justices if the Court, as a fiduciary and loyal public officer, would not dispose the right of nationals on the basis of coarse provisions of international treaty, perhaps mostly public as well as less reduced nor transferable to obligate the citizens concretely. It also may shudder the politicians of Republican ethos if the Court referenced an international precedent to outlaw the execution of minors in view of internationalists or transnationalists (2006).

The doctrine of political question would be one most powerful judicial invention in this area of concerns and in terms of workable government among the coordinate branches. According to this theory, the Congress and Executive are viewed a political branch, and the issues classified within the court articulation would not be justiceable that should be resolved within the political process and as assigned with other two branches. The foreign policy and war powers would, as expected, be most subject to be ruled on this perspective that the Court would normally prefer the judicial disengagement. 
One comparative point may provoke if the judicial action must be bound inherently on the adjudication of civil disputes, restraining a more than flowering design of institutions. For example, the International Court of Justice would be empowered to render an advisory opinion and file an opinion of abstract questions on international law. This could be idealistic if we struggle with the division of responsibility in meeting a war situation between the Congress and President. Along the course of interplay within coordinate branches, the War Powers Act had been promulgated, and the Courts had to agonize itself by tackling with Chadha and ensuring a consistence in the rulings of legislative veto (2006). That is, of course, because the Act includes a legislative veto once rejected by the Supreme Court. Despite this problem, the Act survived, but as limited and comes short to cure all the imperfections, the kind of piecemeal dealings often charted over the history of federal response. Given the tradition of federalism is any powerful in the US constitutional history, the domestic example of unitary government would be improper, yet we would be same to have no firm yardstick to measure if it is justiceable or not (Kim, 2014). As seen in the War Powers Act and use of legislative veto, the controversy involving the constitutional power of two branches tends to resolve with a consultation and agreement of two political branches (2006). The acts dealing with the authority or constitutional power of branches may, in some cases, be called upon judiciary that the sentencing guidelines or independent counsel on specific investigation could be promulgated, but in no way structured as objective and systemic institution or ultimate role of judiciary for the grey area of constitutional issues involving a foreign policy. Given the normative surge of international issues grows, we may embrace the kind of objective jurisdiction regardless of standing requirement that would be framed to enable challenges or cause of action from dispassionate public offices. One comparative example may be found in Korea where the Constitution and statute, respectively within the Art. 111 (1) (iv) and Art. 61 (1), provides the Inter-Agency Dispute Resolution Proceeding. The process would be judicial and the decision should be rendered on the basis of Constitution and administrative laws. Since the Constitution of US lacks the ground for this kind of proceeding, it apparently would be impractical to institute, but the reformers may be sedulous to introduce a similar purpose of institution, albeit, not contradictory with the Constitution.

\section{The Subject Matters and Judicial Attitude}

The quality of issue would bring a little different response by the Court. It would not be unwise to group three classes of judicial challenge often associated with the foreign policy.

First, the war powers and political nature of decision making on the international issues would matter, which generally possesses the character that political branches are most proper to deal with those issues. It differs from any normative quality of international issues unlike other two below.

Second, the status and effect of treaty within the domestic jurisdiction or international customary law often would be illustrated to question the faith of US within the international community, which depends on the legal theory of nations and general operation of case law principle (Breard v. Greene, 1998; Vienna Convention on Consular Relations, 1964). While a new perspective arises among justices, the enriched case laws would effect to bar from leapfrogging the standing judicial practice on international law. As we see, the recent ruling on execution of minors, however, would be seen as remarkable turns that affirmed a square of influence from the international treaties and obligations of US. 
Third, the criminal law areas involving a state proceeding could arouse the treaty obligation of US, notably in the concern of right to confront with the consuls according to the Vienna Convention. Over the series of case, the Court effectively denied the claim of defendant that the government deprived his right to confront and also turned structural to oust the mandate of ICJ rendition to stay the execution of death penalty. In Breard, The Court rejected the claim of defendant on the ground that it was newly added in the Supreme Court violating the rule of criminal procedure or federal evidence (Breard v. Greene, 1998). The case was disposed on the technical ground of procedural issue, but a backlash from international scholars ensued critiquing that the kind of international comity on crimes and punishment had been neglected. In LaGrand, the same had repeated between two judicial authorities involving one German criminal and right to confront with the consuls that the Court disregarded again the request of ICJ (Federal Republic of Germany v. United States, 1999). In Medellin, the Court had not renounced the rulings of prior cases, in which the decision was reached by slim majority and the rulings had affirmed in strong metaphor a dualism between the national and international laws (Medellin v. Texas, 128 S.Ct. 1346 (2008).

While the second and third class could be judicially deliberated on the theory and case laws, some issue, such as succession of treaties with Taiwan by the Carter Administration, would be distinct that concerns an inherent limitations as commented above. The criminal law cases above also could be perceived as differs since the execution of minors is merely of policy issue other than that of hard character bearing on procedure and structure of criminal justice system. One other issue on criminal law would be a war regulation to punish the sales of armaments to the country in armed conflict with the US, which involves a delegation doctrine in the province of criminal law (United States v. Curtiss-Wright Export Corp., 1936).

\section{A Concluding Remark}

Hence, the technicality of issue, such as delegation doctrine or procedural requirement, could complicate a specific case distinguishable although the cases had same subject issue, hence, same class, to be disputed. This implies that the Court principally should be a judicial organ to state "what is law," which would be any ultimate touchstone in assessing the constraints or lack of constraints in formulating the foreign policy.

While a justiceability excludes many foreign policy issues from a chance of judicial contest, the Alien Tort Claims Act would show a major success in terms of respect of international human rights and protection of environment at global scale, in which the Court enlarged the applicability of international customary law. Given its impact being practical, the consequence is wider that the violators on torture, Genocides, piracy, slave trades, human trafficking, as well as sexual harassers and war criminals would be subject to the US and international customary laws. The constraint or lack of constraint of domestic judiciary would not only stem from domestic law or legal theory, but also has a nexus with the quality of international issues. A contractual nature of treaty specifying the rights and obligations of nation as well as involved with the kind of sub-issues on treaty law as illustrated above, would generally be governed by the traditional logic, often based on dualism between the national and international laws and constitutional theory, such as standing or ripeness, political question. That is because the Supreme Court would vastly be disposed as normative. 
The extent of involvement depends on the quality of issues, and the case laws on the twilight of criminal and international laws preferably could come more in activism with the cultivated progress from humanity and conscience.

\section{A Strict Dualism in the Area of Criminal Law}

As viewed, the judicial attitude of Supreme Court has a tradition of dualism that is stringent generally not enforcing the international laws as a binding norm. In Medellin, the Court ruled that not only the treaty but also international customary law would be predicated on the non-execution presumption. Although the Court cited an international authority to invalidate the execution of minors, the abolition of death penalty is deferred to the state criminal jurisdiction meaning that it would never be a cruel and unusual punishment within the meaning of Eighth Amendment. This criminal policy had controverted a mainstream of international progress under the initiative Amnesty.

In Breard, scholars critiqued that the kind of international comity on crimes and punishment had been neglected (Breard v. Greene, 1998). A.F. Breard, a citizen of Paraguay was charged with the attempted rape and first degree murder that was sentenced to death in the State of Virginia in 1992. His petition to appeal the state court judgment and habeas corpus was denied. He then raised the claim on the Vienna convention that he was unlawfully denied the right to confrontation as secured within Art. 36.1 of Convention. The Court rejected on the ground that the claim was newly added in the Supreme Court violating the rule of criminal procedure or federal evidence. The State of Virginia granted an execution of death penalty, and the Paraguay government filed a complaint with ICJ against the US. The ICJ subsequently issued an provisional measure of protection obligating that the US will take every necessary step to defer an execution until the final judgment is rendered and report it to the ICJ. Nevertheless, the Supreme Court denied a petition to stop the execution and the State had executed in Apr. 14, 1998 as scheduled. In LaGrand, the same had repeated between two judicial authorities involving a German criminal and right to confront with the consuls (Germany v. United States, 2001). Although the Medellin is seen same in view of fact pattern, the court opinion in this case heavily bent on introspection, which shortens a due groove of extrospection within the international community. Pending the fifth circuit of Appeals court, the ICJ affirmed that a waiver to notify the right to confront with the consuls violated the Convention, mandating "to provide by means of its own choosing, review and reconsideration of the convictions and sentences of the Mexican nationals involved in the case (2001)." However, the Court had not renounced the rulings of prior cases, in which the decision was reached by slim majority and the rulings had affirmed, in strong metaphor, a dualism between the national and international laws. The Court had not recognized the scope of international laws as a binding law in the courtroom, i.e., ICJ regulations, UN Convention, Optional Protocol and opinion of ICJ on Avena. The dissenting justices argued that the rule had contradicted the principle of self-execution generally held in the jurisprudence of international laws. They also disagreed that the Court should take the scope of norms as a federal law under the Supremacy clause.

\section{The International Customary Law as a Bridge?}


In Hilton, Justice Gray enunciated, "International law, in its widest and most comprehensive sense... is part of our law, and must be ascertained and administered by the courts of justice, as often as such questions are presented in litigation between man and man, duly submitted to their determination (Hilton v. Guyot, 1895)." His ruling was reiterated in Paquete Havana in 1900, in which he further extended his holding into the area of international customary law as a final resort unless the Court could identify any available treaties or statute and judicial decision applicable to the case at bar. It was reinstated in Banco Nacional de Cuba v. Sabbatino by the Supreme Court, and recognized the state action theory as a component of international customary law (1964). The international customary law is not created by treaty clause or constitutional protocol, rather can be ascertained of its contents and applicability through case laws, and may claim the status of federal common law. In this understanding, the international customary law, given if legally defined as a domestic law, would preempt a state law, in which its priority of effect would be determined among same ranks of federal laws in terms of such eminent maxim at law, for instance, later in time rule. Otherwise, the interpretive conflict between the domestic and international customary laws would be best responded with the traditional theory of presumption on congruity (1964).

I have illustrated one hottest area of criminal policy in contest between two dimensions of judicial authority. The international customary law, at least in view of principled thought by the Court of US, had been adverted so as to be positive originally and basically, but the Court tended to erode its hard application by a frequent invoking of international comity. Justice Gray also addressed this point by illuminating the concept of international comity, "neither a matter of absolute obligation, on the one hand, nor of mere courtesy and good will upon the other....having due regard both to international duty and convenience, and to the rights of its own citizens or of other persons who are under the protection of its laws...the recognition which one nation allows within its territory to the legislative, executive or judicial acts of another nation...(1964)"

Suppose if we are international travelers that would expose us exotic or foreign as well as felt generally to be stripped of the feel of protection or comfort by our home country. We might fear of aggressive or cultural criminal statute and could be apprehended of extensive effect of public regulations or such. From this chance, we may evaluate a court ruling, which would perhaps be median. The expression of Court may allow a double comfort for the aliens of temporary visit on tourism, a shield from the home country or embassy of home nation in terms of duty to protect a national and international comity from the visiting nation or state. Justice Gray, however, regrettably used a soft term, "due regard," while he clarified if it is not mere of courtesy and good will.

Hence, the court opinion seems to effect in several implications. First, the international customary law generally is not a binding law since it requires an absolute obligation for the court judges to apply if found to be so. Second, the ruling of Hilton seemingly pioneered leaving it to the discretion of court and conscience of international travelers, which is the kind of essential ingredients in terms of sociology of law and common law evolution. Hence, the ruling of had not been necessarily to exclude the normative quality and potentially binding power of international customary law. Rather the court judges could exercise the power to create a judge made-law depending on the conscience or humanity standard. This appears more persuasive provided that Gray had ruled out such extent of indifference, "mere of courtesy and good will (1964)." Third, the responsibility of national government may come in conflict with the domestic system, for instance and notably, a 
federalism issue in the US. The foreign travelers could be incomplete since he or she often is exposed to the national criminal system or uniform regulation in his or her hometown. That would not be a case, though practically leveled similar with the civil compassion, when he travels a federal system of nation. That would perhaps exactly the issue of this week as briefed above and involving the treaty obligation other than international customary law. The illustrations convivially prove several aspects under our consideration. First, the technicality of common law often intervenes, in most prevailing power, to dispose a legal status of subject issues between the national and international norms, as we noted in the statement "the claim was newly added in the Supreme Court to disqualify a due review" or "due regard" in the words of Justice Gray (1964). Second, the common law judges would be bound more heavily by the national laws, but could seek their space of leniency from conscience and humanity in creating the laws unless a stricture of structural or formality issue would be present to impede. Third, the quality of international issue has to bear in thoughts that the strategic area, such as diplomacy and war, would often be more probable and perhaps desirable on the kind of constrained judiciary. I suppose that the human rights or criminal law area could be more prone to reduce into a concrete legal theory.

\section{Most Advanced or Idealistic?}

In response with our theme, it could be helpful to survey one theoretical tenet of Habermas concerning the world society without central government. It was influenced by the Kantian idea, "world regime of perpetual peace." In his assumption, the most inherent problem of world society would be lack of integral legal system, which is unparalleled with the nation state. Therefore, Kantian idea had inculcated the foundation of League of Union, and Habermas thought that it would be kind of intermediate quality of union voluntarily associated with nation states, and the kind of necessities toward a regime of perpetual peace (Chung, 2013). This interim institution also might be meritorious and attractive to him since Kant feared of autocracy of world government encompassing all the nations. For Habermas, his concession with the League of Nations, the kind of alternative or replacement from his original idea, seems inevitable with the intrinsic flaws of his constitutional theory. In other words, his idea to constitutionalize the international law had a root basis on the French Republic and theory of national constitutions, in which the nation and constitution are grounded on its citizen or denizen. This formality would hardly allow a compromise in reality and brings a limitation as practical option. The frame of Habermas is distinctive to focus on the "function" of liberal government, which was stigmatized on the distribution of power as well as check and balance mechanism, other than Kantian's creationism of one central government and establishment of constitution (2013). The world society or world government within the thought of Habermas, hence, tends to fuse the nations and constitutional concept by a creative reading toward it. So we would be right to perceive his proposition through the kind of idea, for example, separation of powers principle, as well as in terms of reforms and understanding of the contemporary world society. In the constitutional state, we can find a triad of important elements structured with statehood, democratic constitution and civil solidarity (2013). The second and third elements can be shared as trans-boundary, but the statehood is distinct and as limitations, from the monopoly of violence and systemic institution to support such arrangement. Then his message would be for the world society of non-state nature rather than world republic, in other words, world domestic politics without a world government. His proposition would be detailed with identifying the multi-level system, which sustains a democratic constitutional order of world society. It contains three types of world arenas (supranational/transnational/national) and three collective players (world 
organizations, regional or continental regimes/nation-states) (2013). The cosmopolitanism of Habermas would be median in quality while it is highly programmatic for the policy, political or social intelligent group, but may only be spiritual or stimulating for the progressive national jurists. Nevertheless, it represents a most practical posture of idealistic solution, and possibly guides given his focus on common experience, civil institution and the notion of shared governance. His focus perhaps largely pertains to the element of common law system or its evolution. As suggested, the crucial strand in terms of "judicial cosmopolitanism" could be derived from humanity and conscience as hinted by Justice Gray, which possibly engineers toward any conceivable unity of national courts. 
Reference

Banco Nacional de Cuba v. Sabbatino, 376 U.S. 398 (1964).

Breard v. Greene, 523 U.S. 371 (1998).

Chung, C.Y. (2013). Habermas's understanding of cosmopolitanism and the constitutionalization of international Law, CHUNG-ANG LAW REVIEW, 15 (2).

Cohen, H.G. (2006). Article: Cohen, H. G. (2006). Supremacy and diplomacy: The international law of the U.S. Supreme Court. Berkeley Journal of International Law, 24(1), 273-329.

Kim, Kiyoung, The Separation of Powers Principle: Is it a Lynchpin or Pushpin for the Voyage of American Public? (August 1, 2014). International Journal of Advanced Research (2014), Volume 2, Issue 8, 887-895. Available at SSRN: http://ssrn.com/abstract=2573560

Federal Republic of Germany v. United States, 526 U.S. 111 (1999).

Germany v. United States (2001). I.C.J. 2001 I.C.J. 466.

Goldwater v. Carter, 444 U.S. 996 (1979).

Hilton v. Guyot, 159 U.S. 113 (1895).

Howard, G. G. (2001). Combat in Kosovo: Ignoring the war powers resolution. Houston Law Review, 38(1), 261.

Medellin v. Texas, 128 S.Ct. 1346 (2008).

United States v. Curtiss-Wright Export Corp., 299 U.S. 304 (1936).

Vienna Convention on Consular Relations (1964). 21 U.S.T. 77. T.I.A.S. o. 6820, 596 U.N.T.S. 261, art 36(1)(b) and (c).

Vile, J. R., \& Menez, J. F. (2010). Essential Supreme Court decisions: Summaries of leading cases in U.S. constitutional law. Lanham, Md: Rowman \& Littlefield Publishers. 


\section{A Thought on the Federalism}

\section{Overview}

The federalism had been a center of structural congruence or incongruence debated or revamped within the constitutional history. At the beginning, one would be accustomed between the confederate forms of government and unitary one (Vile \& Menez, 2010). In the former, a vast tonnage of state role or responsibility was vested within respective state that the power flows from each to the people and that the confederation was created to meet a limited scope of defense needs as we see in the Articles of Confederation (2010). As the federal union was being discussed and federalist paper discloses, the new Constitution successfully invented a unique design of government, what we now experience. The structure of government and distribution of power are major theme that the modern constitution has to address, perhaps more classic and a priori, even before the bill of rights. Given the bill of rights are an essential attribute of modern constitutionalism, say, the enlightenment spirit, tenet of social contract as well as universal liberty and equal protection of law, the consideration to structure a government within the constitutionalism could retrospect as antedated as the Greek thought on polity or Bodin's and Hobbesian view to the sovereign power. In other words, it deals with an inherent arrangement for the political community and with the thought on the nature of political power as well as most desired form of institution.

The federalism, in its nature and semantic scope, invites two tiers of government, i.e., federal and state government, and deals with their relationship in exercising the constitutional power. This led to the places of constitution, such most directly as Art. 1 Sec. 10, IV and VI, Tenth and Eleventh Amendment (2010). Art. 1 provides the organization and constitutional power of Congress, importantly in the frame of specific enumeration, and Sec. 10 elucidated the federal ambit of legislative, hence, creative, power by proscribing the states from a certain scope of governmental function (2010). For example, the Contract clause prohibits the state to infringe with the existing contract, which would perhaps initially be intended to prevent a state intervention to muddle or make it discursive the war purpose. The federalism, in this kind of origin, hence, could be viewed as circumstantial and historical that, however, deeply but in contingency from modern terms or sense of nationalization - had been embedded to determine the mode of governmental function. Provided if the Sec. 10 is concerned between the federal and state governments, the Art. IV can be viewed as to structure a horizontal ambit between the states so that the state government, for example, has to grant the privileges and immunities for the citizens of other state. Its deprivation failed the states in terms of constitutional obligation, and the Dred $v$. Scott is generally considered to show that the cause of civil war had embroiled with this kind of violation. The Article also concerns of interstate chaos involving the interposition, admission, destruction, secession, succession of states within the federal structure, which can threaten the vitality and essences of federalism. It, therefore, impose the duty of federal government to ensure a Republican form of government for the states (2010).

In exercising the federal power, the impact on the state government could be made in two dimensions. First, the constitution itself provides the limitations and requirements that the state government should respect (Kim, 2014). Art. 1 Sec. 10 would perhaps be most notorious, and Tenth Amendment would be otherwise so as to vest a comprehensive residual power within the state government. In places, the Constitution itself preempts the exercise of 
state power. For example, the state action unduly abridging the interstate commerce could not be tolerated since it violates the commerce clause. Second, the Congress may enact the statute in conflict with the state laws which arouses the issue of federal supremacy and preemption. In this case, the statute may be express or implied to conceive of the state laws as preempted. The express preemption occurs when the statute specifically prohibits an enactment in conflict with it (Linder, 2009). This dealing apparently would facilitate the court work on finding a justice concerning the structure of government. However, the express preemption still requires that the Court be scrupulous in examining the pieces of conflicting legislation since the Constitution is ultimate to resolve the controversy between the Congress and state. It is so also because both forms of federal preemption require a similar review to determine on the conflict and field once the congressional intent is ascertained impliedly. The implied preemption would not be proposed in direct wording of Congress on preemption, but still deserves a federal supremacy and entails the constitutional issue of federalism (2009). Fortunately, the general standard to deal with federal preemption has been devised in case law and well has been held uniformly at least in terms of subject matters in conflict. More important in deliberation to impose the preemption would it stem from the technicality or science within the expertise of specific administrative field, which would be related with the statutes as additive or coincidental other than those in conflict or with the opposing scheme.

The Court in Nelson had been posited to address that kind of challenge given the federal and state laws would be directed to the same purpose (1956). Most controversial is this challenge in the recent Supreme Court case, Wyeth v. Levine, which incurs the problem on the FDA preemption and patient welfare (2009). FDA had a sufficient basis to support a uniform warning label requirement which was disputed in the civil action on tort damages within the state. A typical tort theory would prefer to protect the poor plaintiffs harmed by drugs or medicine, which could also be vindicated by the experts in medical science. In other words, the scientific community could split with a conflicting view in the advancement of public health, in which the FDA preemption was rejected by the Supreme Court (2009). In some simpler prism, the case exhibits a nodal conflict of two stellar dimensions between the common law ideal and modern administrative frame involving major technicalities. They were viewed as separate and independent ground by the Court, and the traditional requirements validating the tort liability, such concepts as duty of care or prima facie case, was considered as primate to recover a civil justice. It is the kind of distributive justice, specifically between the tort feasor and victim that should not be merged by the public cause or quantitative science, i.e., the basis of public administration under the influence of the kind of utilitarian idea. In other purview, the kind of regulation could facilitate the trade and commercial transactions by administering a uniform warning requirement. This aspect exactly would be the concern of WTO non-tariff barrier which avails of national standard, scientific requirement and technical unit. Since the purpose and objective of public administration basically deals with the liberal market in capitalistic society, the free trade and uniform regulations are idealistic, which might be seen to cripple from the decision.

\section{Some Basic Rules on Federal Preemption}

As known, the Article VI, Clause 2, what we call the federal supremacy clause, mandates the hierarchy of norms within the union, and the judges in every state shall be bound thereby. It is interesting to specifically mention "judges in every state" as a receiver of this principle-no saying about other agencies- such as Congress and Executive Branch, and even the state governments. The judges may be federal or on state duty, which implies their 
crucial importance in maintaining the conflict of diverse sources of law. That also can be scratched onto the theme of judicial review and general view of judicial finality on the constitutional controversy over the global jurisdictions. It also relates with the role of oversight to ensure the rule of law ideals within the public administration. Since the federal laws themselves are from sources-tiered tacitly and in practice, if not phrased explicitly in the Clause-the federal regulation or executive order will overrule the state laws even including the state constitution. In this context, the Federal Agency Administration Guiding Principles, Executive Order 13132 of August 4, 1999-Special Requirements for Preemption-mandated that the agencies, in taking action that preempts state law, shall act in strict accordance with governing law.

We also can be hinted on its importance that the Clause, by providing "anything in the Constitution" expressly, granted a unique- or at least exclusive status of federal supremacyimplies of a basic perception of drafters, who intended to maintain the normative integrity of federal union other than the kind of inherence test between the state and union. As Albrecht and Jellinek postulated, the state or sovereignty may inherently be legal-hence "legal sovereignty," which distinguishes from the traditional notion of sovereignty on "divinity of monarch" and "popular sovereignty." This Clause generally impacts on the scope of state power in specific policy area, which should be exercised as in comport with the case laws concerned at matter. The doctrine of federal preemption has since been developed to have several elements as a rule. In Altria v. Good, the federal laws that conflict with a state law will trump or preempt that state law and the Courts ordinarily accept the reading that disfavors pre-emption. This can corroborate the general notion of "constructive interpretation" or "legislative sovereignty" leading to a least judicial intervention when feasible. In Wyeth $v$. Levine, so-called two corner stones of pre-emption jurisprudence had been affirmed (i) the purpose of Congress is the ultimate touchstone in every pre-emption case." (1996) (ii) the historic police powers of the States are not to be superseded by the Federal Act unless that is the clear and manifest purpose of Congress. With respect to this basic purview, we may infer several types of preemption can arise, which concerns preemptive intent as express or implied (1977). The "conflict and field preemption" would be any popular classification in the court frame. The conflict preemption occurs in various context, in which the courts devised between the actual conflict (1963), obstacle (2000), and minimum safety standard v. virtual safety standard (2000). The field preemption occurs if the federal regulatory scheme is so pervasive as to "occupy the field" in that area of the law (1992).

\section{Pennsylvania v. Nelson}

In Pennsylvania v. Nelson, the state law criminalized a seditious conduct which was federally preempted by the ant-sedition act (1956). By providing a seditious conduct as one of punishable crime, it is meant to advocate the violent overthrow of the United States Government. The proscription of such activities and its criminalization were "coincidental'not in conflict - with the federal act. The federal preemption or operation of federal supremacy clause generally takes an effect on the defective provision that the state authority opposes federal laws, hence, in conflict with the intended scope and content of federal law. In this case, the federal law covers not only the acts legislated by the Congress, but also the regulations and rules created by the Executive branch (1956). In Nelson, the Court elicited a need to preempt the adulatory or coincidental state measure for preserving the uniformity and integrity of federal purpose through the nations-perhaps as indiscriminately or in greater justice and efficacy. Practically, the fragmented scenarios of applying both federal and 
respective state acts could prejudice a criminal justice on one hand and could abridge the centralization of federal purpose on the anti-communism and defense of national government. For example, unitary administration employing the FBI or CIA could serve as an effective response with the challenges and threats, as well as information gathering or enhanced criminal investigative process (1956).

On the while, the Nelson raises a similar structure of balancing and weighing since the Supreme Court invalidated the same purpose of state criminal statute (Pennsylvania $v$. Nelson, 1956). The Court position can be received in three counts of rationale (i) Given the same subject matter, coincidence is as effective as opposition, and a state law is not to be declared a help because it attempts to go further than congress has seen fit to go; (ii) the federal statutes touch a field in which the federal interest is so dominant that the federal system must be assumed to preclude enforcement of state laws on the same subject; (iii) enforcement of state sedition acts presents a serious danger of conflict with the administration of federal program (1956).

The Nelson court had considered a criminal institution of nations, which generally falls within the province of state power. Since the federal power is specifically enumerated, the federal purpose of criminal statute also would vacillate with the scope of federal power generally and as not comprehensive. The Court Martial to deal with the crimes of army and navy-perhaps most popular area on the criminal and federal jurisdictions- and such kinds of crime to abridge the federal service or forgery of check of US and coins only could be an object. In this case, the Congress viewed that the anti-sedition act had been necessary and proper to protect a constitutional function of federal government and personnel given it being inherently underlain as federal purpose. In this viewpoint, the state laws, and their creator or implementers could be advised of the basic idea on criminal policy, say, the interest of criminal system and jurisdictional division. In general theory of criminal laws, at least in the civil law countries, the criminal jurisdiction arises on the territoriality principle. This basis of criminal jurisdiction can be supplemented in secondary orders, such as (i) in-personam jurisdiction, (ii) jurisdiction on the victims, (iii) protectionism or universalism jurisdictions. In Nelson, the Court virtually ban these secondary requirements easing the burden of state's tumbling with the criminal policy, in which-in case of federal intervention-the protectionism or universalism, for example, could not be asserted as any basis of criminal jurisdiction (1956). That leads to a queer consequence, but should be a rule since the US maintains a unique quality of national public administration. It can be made distinguishable from other nations, which are obligated-at least in the language of statutes-to collaborate with the Interpol in addressing human trafficking, slave trade, piracy, transactions of illegal drugs or cyberspace crimes. Since the federal preemption involves the scope of subject matters, the jurisdictional conflict deprives whole of competence in dealing with the challenge-meaning that the state governments also is precluded from asserting the in-personam or victim jurisdictions. An underlying rationale seems to ensure the administrative efficacy and integrity, the central control of which is indispensable rather than collaboration or cooperation. The rulings of Court also elicited the leading-perhaps ultimate if patrolled with the Court-status of Congress unless the authority or constitutional ground to exercise the federal power is questioned otherwise. Its impact on the scope of power also could stimulate some response (i) constant check on multiplicity of norms within the responsibility of state government (ii) informal liaison effort to communicate with the federal agencies in the field (iii) the MPC (model penal code) is no less important so as to refer in drafting a criminal code of state. 


\section{The Synthesis of Wyeth v. Levine}

In Wyeth v. Levine, the Supreme Court held the federal law does not preempt Levine's claim the Phenergan's label did not contain an adequate warning about the IV-push method of administration (2009). This ruling affirmed that the federal regulatory clearance of a medication does not shield the manufacturer from liability under state law. In this case, the respondent, Diana Levine, sued the pharmaceutical company Wyeth in Vermont court based on injuries she suffered after she was injected with a dose of Phenergan, an anti-nausea drug manufactured by Wyeth (Wyeth v. Levine, 2009). She was a professional musician and initially went to a Vermont hospital to reduce the migraine pain. The intravenous injection of Phenergan could caused gangrene and ultimately amputation if the drug penetrated a patient's artillery, which was known to Wyeth. She actually had to amputate her right arm and the trauma and excruciating pain is especially embarrassing since was a creative artist. She won a jury verdict in Vermont, under the theory, inter alia, that Wyeth had inadequately labeled the drug and that Wyeth should have precluded the IV-push-method of administering Phenergan, given the known and serious risks. This is particularly so since the need of IV-push method is insignificant while other safer methods were commonly used to treat nausea. The Amicus briefs filed by the supporters of Wyeth, such as the Chamber of Commerce, Product Liability Advisory Council, and the federal government asserted that the contrary ruling of federal preemption would frustrate the purposes and underlying objectives of federal drug-labeling law (2009). The federal preemption was alleged with implied intent of Congress given no express mention of preemptive intent from the Congress (Altria Group v. Good, 2008). The regulatory background for Phenergans had been extensive implying the significance of pharmaceutical industry in US and important role of FDA in the field of drug administration. Ever since the FDA first cleared injectable Phenergan for use in 1955 and several supplemental new drug applications in 1970's, FDA and Wyeth intermittently corresponded about the label of Phenergan until 1998 (Wyeth v. Levine, 2009). About the 1988 submission, FDA suggested different warnings about the risk of arterial exposure, which was responded with proposed changes. Nevertheless, the labeling requirement remains same with the 1981 application "must be identical" with 1996 instruction "retain a verbiage in the current label." This fact implies that 1988 submission could lead to more adequate warning, which possibly prevents the occurrence of her misfortune (2009).

\section{The Majority and Dissenting Opinion}

The majority court firstly assumed that the question is whether the FDA's approvals provide Wyeth with a complete defense to Levine's tort claims. While the court affirmed the lower court judgment, it concluded that it is not impossible for Wyeth to comply with its state and federal law obligations and that Levine's common-law claims do not stand as an obstacle to the accomplishment of Congress' purposes. The issue of this case is whether the FDA's drug labeling judgments preempt state law product liability claims premised on the theory that different labeling judgments were necessary to make drugs reasonably safe for use (2009).

Upon the two separate pre-emption arguments, the Court held (i) the purpose of Congress is the ultimate touchstone in every pre-emption case. (Medtronic, Inc. v. Lohr, 1996; Retail Clerks v. Schermerhorn, 1963) (ii) "in all pre-emption cases, and particularly in those in which Congress has legislated ... in a field which the States have traditionally occupied, ... we start with the assumption that the historic police powers of the States were not to be 
superseded by the Federal Act unless that was the clear and manifest purpose of Congress." Lohr, 518 U. S., at 485; Rice v. Santa Fe Elevator Corp., 1947).

While looking into the legislative history of federal regulations of drugs and drug labeling, the Court denied the argument of Wyeth that Levine's state-law claims are preempted because it is impossible for it to comply with both the state-law duties underlying those claims and its federal labeling duties (Wyeth v. Levine, 2009). It found as contrary on the record that unilateral addition of necessary warning would not have violated federal law governing unauthorized distribution and misbranding. As the Court affirmed, impossibility pre-emption is a demanding defense. On the record before us, it found that Wyeth has failed to demonstrate that it was impossible for it to comply with both federal and state requirements (2009). The court also rejected the second argument that requiring it to comply with a state-law duty to provide a stronger warning about IV-push administration would obstruct the purposes and objectives of federal drug labeling regulation. On the record, the court ascertained the Congress' decision not to pre-empt common-law tort suits, and elicited that the FDA traditionally regarded state law as a complementary form of drug regulation (2009). As the circumstantial evidence, the court illustrates FDA's limited resources to monitor the 11,000 drugs on the market, manufacturers' superior access to information about their drugs, utility of state tort suits to uncover unknown drug hazards and to provide incentives for drug manufacturers to disclose safety risks promptly as well as a distinct compensatory function, which all supports the premise that manufacturers, not the FDA, bear primary responsibility for their drug labeling at all times and FDA's longstanding position that state law offers an additional, and important layer of consumer protection that complements FDA regulation. The Court also rejected the argument on the Geier as distinguishable, which lends to support the dissenting opinions in this case (2009).

The dissenting opinion from Justice Alito and Scalia majority court countered the position of majority court (i) although the Court denied that Levine's state law claims are preempted because Wyeth can comply with both the state law duties underlying those claims and its federal labeling duties, the degree of State's intrusion upon the federal law is irrelevant (ii) pre-emption is arguably more appropriate here than in Geier because the FDA declared its preemptive intent in the Federal Register, but the majority falsely dismissed the FDA's published preamble inherently suspect and an afterthought that is entitled no weight (2009).

The dissenting opinion specifically pointed out; (i) it is not supported that there is no conflict because Vermont did not mandate a particular label as a replacement for the one that the jury nullified, and because the State stopped short of altogether contraindicating IV-push administration; (ii) it is not tenable that conflict preemption in this nature of circumstances is appropriate only where the agency expresses its preemptive intent through notice and comment rulemaking-hence had to be distinguished from Geier; (iii) while the court distinguishes Geier based on the force of law, the materials of case is crucial in the conflict federal preemption, and additionally, the FDA's discretion could make its labeling decisions through the administrative adjudications rather than through less formal and less flexible rulemaking proceedings; (iv) while the Court sandwiches its decision of Geier between the presumption against preemption and heavy emphasis on the longstanding coexistence of state and federal law and the FDA's traditional recognition of state-law remedies, the Court was gone too far by applying "ordinary" "longstanding," and "experience-proved principles of conflict preemption", and by stating that the sole question is whether there is an actual conflict between state and federal law; (v) between the agency's regulatory objectives and the 
effects of state tort suits on the federal regulatory regime, the dissenting opinion stands with the FDA's view that the state torts will disrupt the agency's balancing of health risks and benefits, and emphasized that Geier does not countenance the use of state tort suits to secondguess the FDA's labeling decisions and the Court's contrary conclusion has potentially farreaching consequences (2009).

\section{A Consequence on the Public Policy and Individual Rights}

\section{The Consequence of Dissenting Opinion}

According to the dissenting opinion, the consequence on the right of individuals and public policy would arise. First, requiring the drug administration it to comply with a state law duty to provide a stronger warning would interfere with Congress' purpose of entrusting an expert agency with drug labeling decisions, which should be a tenable interpretation of congressional intent and an overbroad view of an agency's power to preempt state law in this area of public policy (Altria Group v. Good, 2008). Second, the policy makers will deliberate on the crucial question of this kind by asking who has the authority and responsibility for determining the adequacy of Phenergan's warnings. In other words, they may not explore whether a state tort jury can countermand the FDA's considered judgment of mandated warning label and make themselves complete to render the intravenous use safe. This effort to possibly discourage a scrupulous labeling regulation in the interest of federal purpose and interests eventually can lead to less substantial protection of individual rights on the traditional legal theory of tort damages, in this case, raised in the form of product liability claim. The opinion elicited that, to the extent that the purpose of Congress is the ultimate touchstone, the FDA determines, in accordance with the statutory mandate, that a drug is, on balance, safe (Medtronic, Inc. v. Lohr, 1996). This prohibits any State from countermanding that determination, and the state court cannot function as expected of that very institution, which is seen, in my view, to conform with the theme of workable government, say, a postulation required of separation of powers principle as extended to the controversy of federalism in this case. This seems contrary to the tradition and history although the dissenting view filed, "a faithful application of precedents involving conflict preemption cases compels the conclusion that the FDA's long effort to regulate the safety and efficacy of Phenergan pre-empts respondent's tort suit" (Geier v. American Honda Motor Co., 2000). Forth, the dissenting opinion sanctified the role of federal agency and uniform as well as science-based federal administration could be enforced, however, with the reduction of inherent plurality and co-existence of the dual tier of governments. With its consequence, the FDA may truly be a federal agency empowered to strike the balance between the costs and benefits of administering Phenergan IV push (Wyeth v. Levine, 2003). The ruling can be expansively employed, which is, in principle, apply to various federal agencies and hierarchically under the mandate of Congress. While the dissenting opinion emphasized that Geier compels the preemption of tort suits that would upset that balance, it stated, "the contrary conclusion-against Geier-requires turning yesterday's dissent into today's majority opinion" (2003).

\section{The Consequence of Majority Opinion as My Position}

The consequence of majority opinion on public policy and individual rights would follow that I generally agree on it. First, the federal preemption is adjudicated to support the specific justice and not in contradiction with the structural harms on existing institutions, 
which requires the federal offices are also co-government with state offices in some extent and are viewed substantially to address the interest of US citizens (Scott, 2010). Second, the structure of government and inherent interest of federalism between dual authorities may supersede the balance argument that often would be cited to ground the role or responsibility of federal agency. This indicates the important duty of Supreme Court that should support the sound maintenance of federalism and constitutional government. While the political branches execute a creative role of public policy and implement the laws and rules, the Court would affirm what the constitution and law must be. This quality of institution had long endeavored on the separation of powers principle and federalism in the US, which impacts the kind of formalistic triad, in my view, "structure, public policy and individual rights." The public policy requires to strike the balance between the resources and costs in the end to realize the greatest happiness for the greatest number of people, which is, in intrinsic, political and administrative. Two competing values would arise with the goal of "workable government" and "protection of individual rights." While both values are shared with the judiciary in extent, they could most properly be defended by the adjudicative body in distinct form of dialectic process within the adversary system of proceedings. This view was once alleged in the past paper, and the consequence of Wyeth would faithfully vindicate two objectives of constitution as pursued within the separation of powers principle. Simply, it would decisively cripple the state courts provided if the Court supported a contrary findings. The traditional institution of common law torts would be indented threatening the century- wise judicial utility to the balancing interest of federal administration, perhaps, adaptive, evolutionary, susceptible of multiple views and quests, and, if worse, with no definite scientific support (Calfee, 2008). In this case, a considerable force of opinion from the medical experts favored the parallel of state tort system, which is more effective to search for the truth of science and especially in consideration of ultimate goal of science, say, to deal with the promotion of human condition or welfare from medication. While we consider the evolution of federal common law, it still would be adequate that the state would be any most proper unit of community in breeding the common law theory. This, of course, does not negate the federal preemption because it also is structurally imposing and the development of modern science as well as national identity had rapidly accelerated over time. We can also find precedents, such as Geier, in which the Court views an adequacy of federal preemption, perhaps less in conflict with the standard of tort damages, and other circumstances could compel such ruling (Geier v. American Honda Motor Co., 2000).

The Geier case also guides that the court position would never come insipid or dormant merely because it deals with structural issue. The extent of harms in Wyeth is tragic to amputate Levine's left arm, and the stewardship of federal agency and Wyeth, one of biggest profit yielder in the pharmacy industry, had perhaps disappointed the Justices. Interestingly, some important aspect for the Court is the sandwiched position of Wyeth, which allegedly should have to violate the federal regulation by giving additional warning. The claim was, however, rejected by the court based on the legislative history and supportive evidence. One other point needs to be noted why the medical professionals had not been subjected to the suit, who should exercise a due care to protect Levine in intravenous use of Pehenegarn (Wyeth v. Levine, 2009). That possibly would be because Wyeth is more than affordable defendant to the convenience of collection of judgment award, or the cause of action could not require such high degree of care for the doctor and nurse, which suggests a diversification of science professionals at traditional torts. Since the public policy is pivoted on the science and law, this aspect may not be irrelevant for the policy makers. The case, in short, divulges comprehensively a scope of implications, which involves the disparity of 
economic status and bargaining power between the interested parties and the role of public policy to regulate the capitalistic market. The product liability would find its way as sustained by the Court, which could restore the balance of justice on one hand and protect the individual right on the other (2009). It would well incur the new perspective and ways of approach in terms of public policy involving the drug and food administration. The financial damage on the kind of businesses would not be nugatory given the tremendous amount of punitive damages. The kind of no-fault insurance scheme on tort liability could be invented or strengthened to meet new challenges. In some view, the punitive damages itself would be argued of the need of reform on the ground that it is an unconstitutional institution as antedated from the common law heritage.

\section{On the Federalism and Federal Preemption}

In respect with the federalism and federal preemption, two features seem as most characteristic. First, it had been originated by US, hence should be a unique system until the protégés to import a similar system in implanting its sprit and utility. Second, while other constitutional institutions, perhaps horizontal among the peer branches, had been intended any vehemently to embed the separation of powers principle, the province involves in a mixed goal about the staticism or sovereignty and strand of public administration. It implies firstly to question what is an inherent being as a state or sovereign between the state and federal union, and secondarily how both tier of government related with each other (Vile, J. $\&$ Menez, 2010). Between the state sovereignty and federal supremacy, the vertical forge or top-down approach simply could not be plenary unlike the unitary system of government, and could be bridler or hampered in occasions. At the beginning, it had been no unparallel with precedents or historic lesson, which is distinct from constitutional ideas, protection of human rights, traditions of Curia Regis relayed with the thought on the rule of assembly body, presidency received as modern replacement of King, judicial review, and so. Most importantly, the concern possesses a quality of complexion that other province of structuring the national government would be intermediary and stems from the traditional thought of agency concept, which should be made as differs from the economic or wealth basis of controversy underlain between the state and federal government. It is really original and subsequently had led to a federalism thicket as intrigued through the generations of Supreme Court history. While we consider John Locke laid the ideals and paradigm of civil government, he and other enlightenment thinkers had not even conceived of this institution which required to pay the bitter price civilly on war and institutionally on the search for what is best for nation and general welfare as well as other important constitutional values, such as humanity and conscience or pleasure or growth and evolution on public system. Generally the tenet of social contract would inspired and heavily influenced the establishment of this union, a very plausible understanding guides the protection of new wealthier class should be viewed as a prime stimulus and engine of designing the Constitution. The view of plutocracy has argued that such initiative of founding fathers is considered to gear up with creating the Constitution, perhaps well vindicated with their planning forum of federalist papers (2010). While I mentioned the sprit and utility as well as inherent being as a state, the kind of dualism would be employed in our neighborly institutional thoughts even if we consider differentiating the SP since it relies on the horizontal distribution. The Supranational, transnational and international organizations have enjoy an exposure in this peace regime as a matter of world politics. From the general point of view, the principle of subsidiarity is useful lens to characterize its element and understanding of inter-unit essences, but could be flawed in terms of realism tenet which intends on the history and process of evolution on event and 
interactions. The formality only may jeopardize generating a stranded and realistic view about politics or relationship, hence, viewed skinned to pervert a plausible road to interact. This kind of concern may be exemplary in the scholarly approach. Once a Chicago school of neo-realists had been critiqued by realists in describing the progress of European Union by Carr and his disciples since they massively curtailed the history and wake of experience in the interest of formalistic truncation. In their thought, this well imperils an existence of European politics and social ethos shared and disciplined leading to the unpersuasive European unionization, hence on federalist cause, and cripples the diversity of national positions. In spite if the American federalism permeates to influence the European politics in the progress of federalization there, the lesson can remind reversely to revisit the federalism of US (Scott, 2010). Given the surveying technicality at that time, most of colonialists would aspire the similar size of mainland Britain that the state had been considered really an inherent being as a state. The westward expansion and subsequent admission of states also plainly evinces that thesis that they develop the idea of state size in consideration to grant the statehood. In terms of this originalism argument on history and geography, the state truly is the unit that the political power and public administration resides within, hence, the kind of sovereignty or supremacy there. This generally would lead, in the federalism of US, to restrictive reading of federal power and federal preemption has to be strained based upon the crucial purpose of Constitution (Linder, 2009). In my view, the radical constructivism can be interposed that the progress of community in terms of human and social awareness has to be in place. Now the US can be more properly sensible to many people as an inherent being as a polity and inviolable unit of public administration. The development of mass media and increased exposure to the frame of whole nation other than state could convert or inculcate the impression of US as their true state (Scott, 2010). The kind of view may extremely stretched to include the discourse of e-vote and cyber space of notion in delineating the aspect of politics and understanding of national and international community. The extreme internationalists consider a world citizenship or congress to respond with high speed of global compression geographically. The history may be partially experienced of increased profile of international organizations and anarchists, variegated quality from the traditional anarchists. Some may prefer to use the word of international government or officer although the UN security council is unique to be empowered with coercive action, and ICJ never been pompous, but slimly through an advisory opinion-at least in sense and to surmount the state voluntariness theory of international law-vindicated to support the UN legal identity in the claim of its officer's tort damages claim. Besides a massive countervailing ground against the extremist view, the kind of neighborly change in notion or purview implies some role of human or social element even in the area of governmental or governance thought. In a semantic dimension, the exposure to such words, in sense with some professional use, would help to create a notion guiding the spirit and utility of that federalism institution (2010). Sovereignty has perhaps a most history in denoting the marshaled political unit that matters with a holistic catch of quality and substances of state element. It connotes everything of political community under the absolute power to rule, hence, primarily economic, political, and administrative notion of effect with perhaps secondary consequence on the social dimension or citizenry. In other dimension, the supremacy is an applied or creative notion seldom matched up with the political mission or arena, which was nonetheless realized in the US constitution (2010). The notion often would be more proper to describe a religious status of something. More simply, we may sway between the Sovereign being and Supreme being. Given a sovereign is secular, it would be daily practiced, practical, and substantial to deal with our public lives. The Supremacy may reincarnate its missionary errand in less frequency as we pay a service weekly for some hours in Church. It would often be principled and 
preaching in higher perception than reality of floor, which might be hopefully moderated by wise ministers known to the reality of secular society. 


\section{Reference}

Altria Group v. Good, 555 U.S. 70 (2008).

Calfee, J. E. (2008). FDA preemption and patient welfare in Wyeth v. Levine. Retrieved from

Chapter 5, "Articles IV and VI: Federalism"http://www.aei.org/article/health/medicaltechnology/fda/fda-preemption-and-patient-welfare-in-wyeth-v-levine/.

Crosby v. National Foreign Trade Council, 530 U.S. 363, 372-73 (2000).

Florida Lime \& Avocado Growers, Inc. v. Paul, 373 U.S. 132, 142-43 (1963).

Gade v. National Solid Wastes Mgmt. Ass'n, 505 U.S. 88, 98 (1992).

Geier v. American Honda Motor Co., 529 U.S. 861, 870, 120 S. Ct. 1913, 146 L. Ed. 2d 914 (2000).

Jones v. Rath Packing Co., 430 U. S. 519, 525 (1977).

Kim, Kiyoung, The Separation of Powers Principle: Is it a Lynchpin or Pushpin for the Voyage of American Public? (August 1, 2014). International Journal of Advanced Research (2014), Volume 2, Issue 8, 887-895. Available at SSRN: http://ssrn.com/abstract=2573560

Linder, D. (2009). The Supremacy Clause and federal preemption. Retrieved from http://law2.umkc.edu/faculty/projects/ftrials/conlaw/preemption.htm.

Medtronic, Inc. v. Lohr et vir. 518 U.S. 470 (1996).

Retail Clerks v. Schermerhorn, 375 U. S. 96, 103 (1963)

Rice v. Santa Fe Elevator Corp., 331 U. S. 218, 230 (1947) ).

Scott K. (2010). Federalism: A Normative Theory and its Practical Relevance, New York. NY: Bloomsbury Academic.

Pennsylvania v. Nelson, 350 U.S. 497 (1956).

Wyeth v. Levine, 550 U.S. 555 (2009).

Vile, J. R., \& Menez, J. F. (2010). Essential Supreme Court decisions: Summaries of leading cases in U.S. constitutional law. Lanham, Md: Rowman \& Littlefield Publishers. 


\section{The Election Fairness}

\section{An Overview}

The election fairness is an indispensable premise for representative government. One man and one vote had been dissed or abridged in the wake of history that equal right of voting regardless of wealth, race and sex had become as lately settled around 1960's. Hence, the right to participate in a political process, in its intrinsic, panders a universal interest of state architect and democratic value notwithstanding the federal type of government. Nevertheless, the constitutional history of US reveals a lesson as marked with important cases, which elicits a guide for how the democratic government should be formulated and representation attains legitimacy as a matter of law. We can question a voting intrinsic from perspectives, say, political, ideological and normative. Some may argue that the national politics would be jeopardized given corrupted funding or discuss the superiority of political promise for the party in the election contention. Others can raise a defect or weaknesses of international strategy for a presidential candidate. In some cases, the opinion leader may flak on an extravagance of social welfare program, or favors the necessities on the right wing ideology to pull up the vigor of nation. A normative controversy is treated by the courts, for example, concerning gerrymandering (Baker v. Carr, 369 U.S. 186, 1962) and public funding of presidential campaign provided if the equal rights to vote are generally completed within the system and across the jurisdictions. The federal framework of US, however, occasionally raises a technical issue of two governments in terms of election administration, which should be fair and in comport with the system and mandate of Constitution. Although the issue involves an important assumption on the legitimate and representative government, it is political in vast nature with a bit of administrative scheme, which leads to judicial theory of political question dealing with the exercise of congressional authority in this area of concern (Klein, 2002). Nevertheless, the Constitution provides a scope of normative requirements in places, as Article I Sec. 2. According to them, the election administration to fill the Congress and Presidency should be a principle duty of state government, which shows that the drafters of Constitution massively hinged on states, perhaps because costs or resources rationale would guide and also because the intent and aspirations of people can more firmly be ascertained through the state legislature. The provision, however, reserved an ultimate authority to alter or rewrite the state laws since the discredit of state at the time had never been trivial or nugatory guaranteeing such need and ensuring the democratic spirit of Independence.

Although the federal supremacy was announced expressly, it is general and the Constitution rarely mentions a permitted federal intervention on specific topic, which is otherwise in the election issue of Congress and until the Fourteenth Amendment added upon the situation of civil war. The subsequent amendments heralded to reflect the evolving paradigm of equal voting right ensued through the Amendments. This far earlier insight on federal control of Congressional election implies the intent of drafters to preserve the integrity and consistence of federal government, which came compromised with the state role and responsibility. The election of Presidency can come in contrast given one clause about the Day. The awareness and culture on this dealing implies (i) that the Presidency was viewed by the founding fathers as some replacement of monarch and the kind of artificial girdling of hereditary taste (ii) the Congress would be a substantial forum of US democracy as the British parliament had developed to play a substantial role in national politics. It is paradoxical that the power of Presidency remains such substantial, however, which is highly 
unlikely to bear same attribute in the contemporary practice of British politics, one of original states of monarchy. The practical consequence of this constitutional framework leads to a different path of congressional action, in which the Congress can be active to deal with the issue of Congressional election and had generally been foregone with the Presidential election. The case laws on the presidential election, as a corollary, would also be scarce to question on the normative challenge of presidential election. Bush v. Gore would be one of unique controversy, while the earlier States can do select the electors on their own, even the State itself (Vile \& Menez, 2010; Bush et al. v. Gore et al., 2000).

The Court in Bush v. Gore raised a concern of equal right to vote that the state election administration was not perfectly orderly, but the strong need to recount had been essential to ascertain the intent of ballot casters. Other important variant was the imminence and urgency of election administration that compelled both judiciaries to agonize how they could protect the constitutional ideals and institution of national politics. We generally know the federal system had been defended with a proper function of Supreme Court, which seems mostly convivial in this challenge. As the kind of underwriter statement is impressive as we read in the court opinion, "none of more conscious of the vital limits on judicial authority than are the members of this Court, and none stand more in admiration of the Constitution's design to leave the selection of the President to the people, through their legislature, and to the political sphere (Bush et al. v. Gore et al., 2000)." The following passage hints on the nature of issue and impending need of Supreme Court, "When contending parties invoke the process of the courts, however, it becomes our unsought responsibility to resolve the federal and constitutional issues the judicial system has been forced to confront (2000)." The situation and development of controversy recalls upon the classic debate in the German circle of modern constitutional scholars, inquiring who is any ultimate defender of Constitution, i.e. presidency or federal judiciary? Although the issue in Germany gradually became conventional with some idealistic and spiritual solution denoting whole of players and subjects under the rule of specific constitution as the defender of Constitution, German contingencies around early of Weimar period and that of US could show that it can possibly turns on specific agencies at least if in the period of peacetime.

\section{The State-Based Election Administration}

\section{Strengths and Weaknesses}

A strength underlying the state-based election administration comes from its resources and locality to more effectively respond with the voters. That is generally viewed practical, as well as sustainable, importantly from the context so as to be less probable with any potential conflict with the Constitution. While fair election crucially depends on simple requirement of free and equal voting, the Constitution imposes no specific obligations with which the federal government must entangle. Hence the kind of "delegation notion" can operate to draw heavily upon the state involvement in election administration. In this case, of course, the federal requirements from Constitution should not be violated.

The weaknesses of state administration would arise from the inconstancies and specificities which may potentially threats the ideal of fair election. In the Bush v. Gore, overvotes and undervotes obviously were treated in discriminatory manner which possibly depraves the legitimacy of federal government and undermines the equal voting right. The genuine problem might underlie less tense and potential vulnerability of state attention, at 
least in terms of administrative practicality, such as machinery and difficulties in recounting, if the state election act is no tainted with flaws or inattention. The case, on the other side, had provided a good lesson which could uniquely occur in the US constitution. Generally, the federal congress would be placed in more competitive position to absorb these weaknesses, and can render the kind of upstaged remedy to improve the ideal of election fairness. The need of federal response seems more proper given that the indirect mode of presidential election is a crucial characteristic, but the Constitution is overly reticent.

As viewed, the strength of state administration underlies its vast resources and directness on the voters, which allows most efficient, but fair election. It means a phase of administration comes more strongly with the use of state and could facilitate such ideals, say, efficiency, efficacy, and public good of convenience (U.S. Electoral College, 2015). As illustrated with the election system of Illinois, the state government arranged a scope of election laws and regulation, which encompasses a thicket of issues to deal with technicality on the election administration, such as voter registration, registration of candidate, election campaign, ballot casting, and vote counting. This wide of particulars generally not only does not fit within the federal scheme, but also because the reality or sociology of administration can view the state government most adequate. The Report reveals this assumption that the major federal statutes had dealt sparse issues, such as timing of federal elections, absentee voting requirements, accessibility provisions for the elderly and handicapped, and prohibitions against discriminatory voting practices (Government Accountability Office, 2001). As implied, the federal intervention generally concerns of equal right to vote and administrative promotion to ensure that goal. For example, sec. 2 of the Voting Rights Act (1965) establishes a nationwide ban against any state or local election law that results in the denial or abridgement of any citizen's right to vote on account of race, color, or membership in language minority group (2001). Congress also has passed legislation intended to improve access for elderly and handicapped individuals, which ensures a positive affirmation in the aim to fulfill a participatory democracy and equal right to vote (2001). In purposes, the absentee voting requirements guarantees a uniformed services voters and absentees in due scope of statute to vote in the federal elections. The act of Uniformed and Overseas citizens Absentee Voting Act (UPCAVA), therefore, was intended to ensure equal participation in the voting, in which the contingent travelers or foreign residents are equally treated in the election process (2001). Although the Constitution had not expressly illustrated to target such classification besides race, sex and age, the federal purpose to ensure an equality and modern principle of representative government could be ascertained in that way.

Moreover, it also facilitates the uniformity of election administration that the states cannot derogate, which is considered undoubtedly to be the authority of Congress as we see in Sec 2, Art. 1 of Constitution (2001). In other words, the Congress is expected to fully swing with the federal elections, especially in the Congressional election, and no constitutional question about federal power could arise unlike in other ambiguous policy areas. This means that the state elections are subject to the plenary discretion of state power generally, which only could be transgressed if the mandate of Constitution, such as votingrelated amendments, is alleged to be violated. Otherwise, the federal intervention in the state elections seems impermissible in terms of specific enumeration of federal power, but, of course, with the constitutional protection relating with the equal protection of laws. Since the selective incorporation of bill of rights are a Court rule, it is not certain if the freedom of expression can be alleged in terms of state election, but can positively be viewed since the federal government has a duty to ensure a Republican form of government for respective state. 
As per voting rights, the pertinent part of Constitution includes article 1, and Twelfth, Fourteenth, Fifteenth, Nineteenth, Twenty third, Twenty-fourth, and Twenty-sixth Amendments, and the Court declared it to be fundamental (Vile, \& Menez, 2010). The Article and amendments are directed to deal with the federal elections. Earlier in the constitutional history, voting rights varied significantly from one state another, and many states recognized only white males to be eligible for voting. The modern administration had a wake over political struggle, federal acts and rulings of Supreme Court. The Court, for example, in Guinn v. United States, struck down the Oklahoma statute establishing time frame to exclude the African Americans, what we call grandfather clause (Guinn v. United States, 1915).The later time in rule would only be applied to equal rank of laws, ruling the constitutional amendment is revolutionary to wholly alter a racial discrimination in the federal voting. In this case, the state action theory was invoked to apply the federal constitution. The Congress also enacted the Voting Rights Act of 1965, which is the chief means to enforce the Fifteenth Amendment (Shelby County v. Holder, 2013).

Voter registration, some of general ingredient within the election law, had been triggered by the federal congress, but the subject matters had been dealt to meet the immediate public challenges, such as same form of registration with the applicants for driver's license, numerous statutory agencies authorized to register and accept the completed applications, and mandatory use of national mail-in voter registration developed by the Federal Election Commission. Hence the purpose of NVRA is administrative seeking uniformity and meeting environmental challenge of new technological development, and can be viewed to intend on the convenient access and unabridged participation. In this sense, the political liberty and equal voting are pivotally intertwined with the election law and administration although the devices or machineries pose challenges in circumstances. In near future, we can be compelled to deliberate the incorporation of cyber space voting as one of legal mode which can be more uniformly administered with the federal initiative. This expectation plainly shows the importance of science and concomitant modal change of our public lives, which impacts to incur an increasing profile of administrative state, especially requiring of the federal response.

However, all these features of federal law supports the view that the federal election law is particular and concerns of basic constitutional mandate as most of attention being involved with equal right in the election process. This means that the principal duty of federal election still cannot but to remain with the state government, which must be said as its strength. This point can also be reinforced that the expense of election administration would be economical from the unitary administration through the federal and state elections. In terms of fiscal adjustment, the issue might arise if the state governments could seek a compensation for the part of presidential election since no constitutional provision clarifies, but it is part of organizing the federal government. The general view probably supports that the state power, obligation on the other coin, is residual and comprehensive negating compensation. For the part of scholarly concern, the research on the election system vastly covers the federal elections and the issues of state election would rarely be explored. This generally suggests a typical attribute of state sovereignty on state election leading to a wide latitude of state authority, and uniform value of election fairness as guided with federal elections (Palazzolo, Moscardelli, Patrick \& Rubin, 2008). 


\section{The Proper Role of Congress}

In my view, the proper role of Congress in exercising the federal power on election administration is to find a nexus between the state primacy and the vital need of federal purpose. The same idea of "negative vesting" with the residual nature of state power can be embraced that the Congress would come with the areas of selective intervention, i.e., basically concerning the constitutional mandate and protection of individual rights, uniform need of election administration, response with the advanced technology of election process, and sanctity of political process and public funding (De Luca, 2007). The degree of intervention would likely be more heightened than "commerce power," but can be similar with the "power to coin," for instance. More autonomy is viewed not only permitted, but also seems to be in need of active involvement with enactment given the recent controversy in the Bush v. Gore. That is particularly because the issue is surely the internal matter of federal government, but borrows the state resources. A centerpiece of federal concern with the election would be to protect from the corrupted public funding and impairment of transparency within the election process. That is because the spoils system in tradition and current practice can well taint a paradigm of fair election and sanctity of public office. In this area, the federal law seems fairly responsive to cure the evils, over history and in the trajectory of Nixon scandal and new federal act on campaign funding (Federal Election Commission, 2015). In 1907, the Congress passed the Tillman Act which prohibits the funding of election campaign by national banks and enterprises. In 1910, the first federal statute was enacted concerning the federal election of Representatives and to make the funding transparent by mandating the disclosure of funders bigger than 100 dollars, submission of receipts and so. The ceiling of Act amount had increased in the 1925 reform. The problem raised a concern of primaries besides the federal election itself, which signified the expansion of election fairness and ideal of democratic representation in the face of increasing importance of primaries relating to the official turnout of federal election. This controversy was clarified in 1921 through the Court decision (2015). Through the 1970's, the enactment and reform of Federal Election Campaign Act had developed a holistic paradigm of funding regulation. Between the so-called soft money and hard money, the Act detailed the legal requirements and consequence. At the moment of 1996 presidential election, the national demand soared that two major parties had to collaborate to produce any due covenant of fair election, which came into fruit by enacting the Bipartisan Campaign Reform Act of 2002 (2015). However, the limitations on the campaign funds need to be carefully designed so as not to abridge the first amendment right of people and candidate (Buckley $v$. Valeo, 1976). The spending power would base the congressional intervention to mobilize and activate the state concern and duty-feel, especially relating with the Presidential election if the Section 2 has no specific mention of Congressional role about that election. A punishment to respond with the electoral crimes including campaign funding is considered if the federal power can scratch onto that. Provided if the federal election is fundamental and elementary to constitute an elected government, it should be allowed. In Ex Parte Yarbrough, the Court reasoned, "That a government whose essential character is republican...it must have the power to protect the elections on which its existence depends from violence and corruption (Ex parte Yarbrough, 1884)."

\section{Election Fairness and the Role of Supreme Court}

\section{A General Thought}


The ballot counting and funding of candidates involve a distinct aspect of election administration that necessitates a due consideration in the end to shape a relevant law and public system. The issues are intertwined with several elements (i) election fairness (ii) individual right to participate in the political or electoral process (iii) separation of powers principle and justiciability (Kim, 2014; Kim, 2015). The election fairness obviously contends in view of public administration which enables the proper judicial role of oversight. The general tenet and theory on constitutional law hence could be applied that the common law judges could vastly exercise its policing role in collaboration of Congress and Executive. As seen previously, the state governments are a principal player to deal with the responsibility of election administration as a matter of constitutional law. The reality of congressional engagement can also differ because the language of Art 1, Section 4 had express an expectation of Congress to engage by specifically granting the authority to the election of Congress (Klein, 2002; Palazzolo, Moscardelli, Patrick \& Rubin, 2008). The current regime in national elections had well been articulated in the Report of General Accounting Office to the inquiries of Congress. Varying with the extent of congressional actions, the cases dealing with the Presidential election would be seldom in comparison with that of Congress (Government Accountability Office, 2001). The Bush v. Gore, however, generally brought an attention how the Congress and Supreme Court come in compass to prevent from exigencies of national stall on smooth and constitutional administration of that election (2000).

The aspect of election administration has features and characteristic in view of proper role of Supreme Court .First, the express constitutional mandate should not be breached and would be vertebrate in resolving the controversies or policy contention of ballot recount and public funding. The doctrine of political question can possibly apply, but generally be considered over most debate of Court proceedings to be justiciable. This implies that the judicial yardstick can intervene to restore the value of election fairness, such as equal voting or freedom of expression, meaning the basic rights toward the democratic representation. Given its central importance within the politics of modern democracy, the right to vote established in modern covenant, such as universal suffrage notwithstanding race, sex, wealth classifications, is "fundamental," in the art of terms ascertained by the Court (Vile \& Menez, 2010). Since it is fundamental, the abdiction or contradiction of such mandate would deserve a strict scrutiny. This, however, never means that the Constitution as well as laws of nation and state government could not exercise a policy rationale in limiting the scope of right. The citizenship requirement or other measures to facilitate the administrative needs can well take a place in public law, which, however, is expected to comply with the Constitution. One question arises if the federal election law could be enacted given the federal power has the nature to be specifically enumerated in the Constitution. That is possibly problematic given the Constitution has no specific mention relating with the presidential election, which possibly leads to be read with implications of inverse intention by the drafters (U.S. Electoral College, 2015). From the language of election clause, some also could allege if the drafters would concern the election basically from the people and state level other than hyped federal structure.

The issue also has the attribute of candidate's individual right besides the election administration. The election administration in US is a system that shares the universal principle and national particulars. In its tenet and principle, the US election system generally is considered as candidate-centered than parties, while the First Amendment freedom of expression offers a crucial element in creating and implementing the election administration (2010). The reason for these two basic traits arises from history and tradition as well as the 
constitutional democracy and rule of laws. It is some of salient attribute that the protection of individual right has a grave nexus to legitimate the public system and policy. It is recognized for the importance of judicial oversight in US and the kind of finality principle tacitly implied in the civil law countries about the constitutional controversy. The Buckley v. Valeo decided in 1976 simply shows how the Court could elicit a due frame of election system by invoking the constitutional rights of disputed party (Buckley v. Valeo, 1976).

The rule of law principle requires the public system to be designed and implemented so that should not impair the individual rights. In that case, the progressives and conservatives commonly raised an aggrievance that the regulation on total expenditure in the election of Congress had contravened the first amendment right of candidate and voters. The Court also ruled on the presidential election, in which the court declared same regulation as constitutional because the limitations of total expenditure are voluntary to qualify for the federal subsidies of election (De Luca, 2007). The Spoils system practiced since the age of independence generally led to the cult of presidency even for the cultivated or wealthy class of people who admired to seek a federal office. It is needless to mention for common people and the candidates, over time and still through the current, have relied on enterprises and wealthier people to meet the tremendous amount of campaign expense. As a corollary, the parties would prefer a charismatic candidate to appeal to public and the system may turn more strongly with candidate than party itself. The Nixon espionage reveals the corrupted history over time which fueled the skepticism and ignited an enactment of the 1974 Federal Election Campaign Act (Palazzolo, Moscardelli, Patrick, \& Rubin, 2008). To the extent, the congressional election bears similar context although the problem would most starkly be raised in concerns of Presidential election.

\section{The Structure of Government and Article III}

We herewith again recall upon the role of Supreme Court in the tripartite scheme that it can intervene by saying what the Constitution is meant to protect the individual right. That paradigm is completely perfect since the individual generally tends to be "holistic and strategic" to raise his interest and right from "perspectives and omnibus of legal ground." As the Art. III Sec. 2 of Constitution provides, "The judicial Power shall extend to all Cases, in Law and Equity, arising under this Constitution, the Laws of the United States, and Treaties made, to Controversies between two or more States..." The Article generally is seen to establish the federal judicial power on diversity and federal question, and the jurisdiction was delineated in two parts, say, original and appellate. Finally in Section 2, Trials by jury in the criminal cases are mandated along with the principle of territoriality in dealing with the venue of criminal jurisdiction, by specifying "such Trial shall be held in the State where the said Crimes shall have been committed; but when not committed within any State, ... as the Congress may by Law have directed." Interestingly the Section prescribes the controversy involving the State, which would be against the private citizens and among the States (Chisholm v. Georgia, 1793). At least within the suit against private citizens, the Eleventh Amendment effectively overturned the pertinent part of Section 2, which prohibits the federal courts from hearing "any suit in law or equity, commenced or prosecuted against one of the United States by Citizens of another State, or by Citizens or Subjects of any Foreign State" (Congress on March 4, 17941 Stat. 402 and ratified by the states on February 7, 1795). The consequence may abridge the institution of proceedings to dispute the election fairness, but could possibly be asserted based on the theory of federal question. The individuals alleging to be harmed over the election process, of course, generally candidates and people could argue 
by claiming his or her constitutional rights, such equal protection, freedom of expression and association, right to travel as briefed below. Although the federal venue depending on the authority of Congress is provided given no specific territorial interest of crimes, the election crimes involving the federal campaign, for example, would generally be dealt in the State where the crime was alleged to occur. While clause 2 of Section 2 provides the original jurisdiction for Supreme Court and the Court has held that the latter requirement is met if the United States has a controversy with a state, the election dispute can possibly be designed to utilize the form of actions among the several states and between a State and United States (Vile \& Menez, 2010). This part of Section 2 imports the notion of state level dispute as such earlier provided that the frame had been conceived by civil law jurists to establish a separate system of constitutional adjudication, e.g. the Conseil E'tat and German or Korean constitutional Court. I also suppose why the forms of action would generally not be formulated in that conflict of interest. In that case, the State attorneys may initiate the controversy of federal election against the State or United States, but may be discouraged for reasons somehow. It can be a good idea, but may not outrival the private interests federally supported by the Constitution as we see the case names in this line of controversy-Baker $v$, Carr (State Secretary), Buckley v Valeo (Secretary of Senate, Ex officio member of FEC), Bush (Candidate) v. Gore (Candidate)- and so. Nonetheless I may scratch on two points in consideration that the decency of debate and resolution would more probably be strengthened with the public system or public nature of litigation given its distinct nature of controversy. The preliminary review officially can be systemized legally with the initiative of Congress as the Conseil E'tat may play. The Congress may enact a preliminary review of state election laws by utilizing the Department of Justice and other agencies, which could provide a formality and decency or sanctity of State and United States. Nevertheless, the private strand and individualism are seen primary to sustain the western liberalism over history which proves truly powerful to engineer in some sectors, for instance, from economy trough the education, and also in the legal lives of contemporary citizens. Armed with the professional knowledge of law, the attorneys would search every ground of legal protection to restore the virtue of election fairness on one hand and effective remedies for the deprived individual. In sum, the role of Supreme Court in the election administration is considered to be pivoted on the protection of individual rights, most often concerning the constitutional due process, equal protections and the First Amendment right.

\section{The Right to Travel and Equal Protection}

Within the law of nature, the right to travel between the states is constitutionally guaranteed, but it has nothing to do with the validity of state residency requirements for the exercise of civil, say, man-made rights. However, the Court positively used this right with the equal protection of law among the travelers as in case, Dunn v. Blumstein (1972). In Dunn, Tennessee closes its registration books 30 days before an election, but requires residence in the State for one year and in the county for three months as prerequisites for registration to vote. Appellee challenged the constitutionality of the durational residence requirements, and a three-judge District Court held them unconstitutional on the grounds that they impermissibly interfered with the right to vote and created a "suspect" classification penalizing some Tennessee residents because of recent interstate movement. Although Tennessee asserts that the requirements are needed to insure the purity of the ballot box and to have knowledgeable voters, the Court ruled that "the durational residence requirements are violative of the Equal Protection Clause of the Fourteenth Amendment, as they are not necessary to further a compelling state interest (pp. 335-360)." The Court requires the State to 
prove a compelling state interest and, ruled that absent it, the State "may not burden the right to travel by penalizing those bona fide residents who have recently traveled from one jurisdiction to another. (pp. 338-342)." The Court also found that "a period of 30 days appears to be ample to complete whatever administrative tasks are needed to prevent fraud and insure the purity of the ballot box (pp. 345-349)." The Court also ascertained, "since there are adequate means of ascertaining bona fide residence on an individualized basis, the State may not conclusively presume nonresidence from failure to satisfy the waiting period requirements of durational residence laws (pp. 349-354)." The Court finally viewed that Tennessee has not established a sufficient relationship between its interest in an informed electorate and the fixed durational residence requirements (pp. 354-360).”

\section{A Campaign Funding and the First Amendment Right}

The issue of campaign funding was dealt in the landmark case, Buckley v. Valeo, that the Supreme Court intrigued the First Amendment rights so as to be adapted with the ideal of representative government and election fairness (De Luca, 2007; 1976)). Additionally, the case was disputed on arguments concerning the proper role of government involving the Article 1, Article II and Article III. The Court held, "this litigation presents an Art. III 'case or controversy,' since the complaint discloses that at least some of the appellants have a sufficient 'personal stake' in a determination of the constitutional validity of each of the challenged provisions ...... as distinguished from an opinion advising what the law would be upon a hypothetical state of facts." This holding reinstates the critical distaste of Supreme Court arguing for the public system and assuming the general role of public policy making. It specifically examined the various provisions of Act which deals with the campaign contribution, expenditure, and disclosure and recording (1976). While the Court declared other provisions constitutional, it invalidated the Act's independent expenditure ceiling on the ground that "its limitation on a candidate's expenditures from his own personal funds, and its ceilings on over-all campaign expenditures, since those provisions place substantial and direct restrictions on the ability of candidates, citizens, and associations to engage in protected political expression, restrictions that the First Amendment cannot tolerate (pp. 3959)." In this complicated case, the Court arrived at two important conclusions in which the court distinguished restrictions on individual contributions to political campaigns and candidates from the restrictions of expenditures. The Court supported the view that the former can enhance the "integrity of our system of representative democracy by guarding against unscrupulous practices," while rejecting the latter since the expenditure restrictions do not necessarily warrant a curtailment on free speech and association. Another issue arose as to the appointment clause of Article II, in which the Commission's composition as to all but its investigative and informative powers was challenged as arguably unconstitutional. The court as a threshold issue perceived the case as ripe for review, which ruling also pertains to the view that the US judicial system is critically rooted in the individualism frame. It is, therefore, to be questionable again if the Congress or President-arguably seen more proper from the Court position in Buckley-could invent any dispassionate and public nature of judicial proceedings, for example, among the States and between a State and United Statesas well as involving the issue of Marbury concerning the original and appellate jurisdictions. While it overturned the judgment of Appeals Court that the Necessary and Proper Clause of the Constitution gave Congress the authority to establish the Commission, the Supreme Court affirmed that the powers of the Act vesting in the Commission the primary responsibility for conducting civil litigation in the courts are unconstitutional since the "Commission, as presently constituted, may not, because of that Clause, exercise such powers, which can be 
exercised only by Officers of the United States appointed in conformity with the Appointments Clause" (1976). This also corroborates that the President or Executive of US type Constitution can be more creative in distinct policy areas- precisely because of the appointment clause- although the assembly body of unitary government is generally plenary at least in terms of creating an influential public office.

\section{A Recounting, Equal Protection and Due Process}

In Bush v. Gore, the Supreme Court ruled that the Florida Supreme Court violated Article II Section 1 Clause 2 of the U.S. Constitution by making new election law and standardless manual recounts violated the Equal Protection and Due Process Clauses of the Constitution (2000). In 2000 presidential election, the Florida Supreme Court ordered, inter alia, that manual recounts of ballots for the recent Presidential election were required in all Florida counties in which the closeness of the election was noted and ballot counting was controversial on undervotes and overvotes meaning uncounted legal votes. The Supreme Court relied on the constitutional due process and equal protection of law by stating, "having once granted the right to vote on equal terms, Florida may not, by later arbitrary and disparate treatment, value one person's vote over that of another." It also affirmed that the Clause's requirements apply to the manner in which the voting franchise is exercised (2000). The case was principally treated from individual rights of voters as seen in the court reasoning, "upon due consideration of the difficulties identified to this point, it is obvious that the recount cannot be conducted in compliance with the requirements of equal protection and due process without substantial additional work." However, it also seems to reveal the dynamic nature of election controversy and crisis of electoral legitimacy. Then we also may be curious why the Court stepped in the controversy. One view from commentators gave an insight, "Why, then, did the Supreme Court agree to get back into the fray after the election of 2000? In a sense, the justices had no choice.... these suits proceeded simultaneously in the state court system and in federal court..... there were charges of voter intimidation, ballot rigging - all manner of political shenanigans. Something had to be done (Dummies-Election Night, 2015)."

Justices Breyer and Souter partly dissented with respect to the remedy, believing that a constitutional recount could be fashioned. They believed that Time is insubstantial when constitutional rights are at stake. Justices Ginsburg and Stevens argued for reasons of federalism that the Constitution requires that every vote be counted. As sensible with the dissenting opinions, the case provides a good example of constitutional defender thesis and fundamental question across the politics, emergency on national crises and legal philosophy, in which the jurists would more endeavor on individual rights in terms of common law intelligence. The Court in Bush v. Gore raised a concern between the equal right to vote and the imminence and urgency of election administration (2000). As viewed elsewhere, the situation and development of controversy recalls upon the classic debate in the Weimar Constitution. Do we disagree if the emergency election chaos of US can possibly turns on specific agencies, e.g., the Supreme Court, as an ultimate defender of National constitutionat least if in the period of peacetime?

This query also brings an interest involving the doctrine of political question as we know in Baker v. Carr (1962). The case arises from so-called gerrymandering in which the district of voting had been designed arbitrarily and in grossly disproportionate fashion, which can substantially infringe with the right of vote on equal terms. Both two cases show the tendency that the Court turned more active to deal with the kind of election issues and less to rely on the political question doctrine. And the constitutional due process and equal 
protection of law are two important lens to gauge the electoral controversy with the judicial yardstick. 
Baker v. Carr, 369 U.S. 186 (1962).

Reference

Buckley v. Valeo, 424 U.S. 1 (1976).

Bush et al. v. Gore et al., 531 U.S. 98 (2000).

Ex parte Yarbrough, 110 U.S. 651 (1884).

Federal Election Commission: Public Funding of Presidential Elections. Retrieved Apr. 24, 2015 from http://www.fec.gov/pages/brochures/pubfund.shtml.

Chisholm v. Georgia, $2 \underline{\text { U.S. }} \underline{419}$ (1793).

De Luca, T. (2007). Free speech, political equality, and campaign finance reform: A paradox for democracy? New Political Science, 29(2), 145-166.

Dummies-Election Night. Retrieved Apr. 29, 2015 from http://www.dummies.com/howto/content/supreme-court-case-study-bush-v-gore.html.

Dunn v. Blumstein, 405 U.S. 330,1972).

Federal Election Commission: Public Funding of Presidential Elections. Retrieved Apr. 24, 2015 from http://www.fec.gov/pages/brochures/pubfund.shtml.

Government Accountability Office. (2001). Elections: The scope of congressional authority in election administration. Retrieved Apr. 24, 2015 from http://www.gao.gov/new.items/d01470.pdf.

Guinn v. United States, 238 U.S. 347 (1915).

Kim, Kiyoung, The Separation of Powers Principle: Is it a Lynchpin or Pushpin for the Voyage of American Public? (August 1, 2014). International Journal of Advanced Research (2014), Volume 2, Issue 8, 887-895. Available at SSRN: http://ssrn.com/abstract=2573560.

Kim, Kiyoung, The Constitution and Tripartite System of Government: From the Mutiny for the Limited Government Through the Interbranch Subtlety. (September 1, 2014). International Journal of Advanced Research (2014), Volume 2, Issue 9, 392-401. Available at SSRN: http://ssrn.com/abstract=2574711

Klein, G. (2002, October 13). Congress tries its hand at fixing elections. Tampa Tribune, p. 1.

Palazzolo, D., Moscardelli, V., Patrick, M., \& Rubin, D. (2008). Election reform after HAVA: Voter verification in Congress and the States. Publius, 38(3), 515-537.

Shelby County v. Holder, 570 U.S. (2013), 
U.S. Electoral College: Responsibilities of the States in the Presidential Election. Retrieved Apr. 24, 2015 from http://www.archives.gov/federal-register/electoralcollege/state_responsibilities.html

Vile, J. R., \& Menez, J. F. (2010). Essential Supreme Court decisions: Summaries of leading cases in U.S. constitutional law. Lanham, Md: Rowman \& Littlefield Publishers. 


\title{
IX. On the Entitlement and Benefit Programs
}

\author{
In My View, the Legitimacy of Judicial Constraints on the Legislative Efforts to \\ Create, Expand or Constrain Entitlement and Benefit Programs Depends on the \\ Normative Particularities than General Theory Given the Nature of Role and \\ Responsibility of Judiciary.
}

\section{A Brief Survey of Cases}

I have been impressed with the positing from Wald, "Is still a safe harbor for the government to allege the neutrality of its role, and therefrom constitutionally innocuous since the function is a mere inaction?"

Let me brief on his suggestion that the Court has neglected on the Fourteenth Amendment analysis with a dormant drawback on the traditional and formalistic judicial craft of unconstitutional conditions. This would be helped with his illustrations of historic cases, which arguably miscarried or overlooked the requirement of the Amendment (Wald, 1990). Given the complicacies from the details of legal dispute, I attached rather an intuitive view on the decision. Then I would discuss some of implications as associated with the Wald' point of view.

\section{DeShaney}

In Deshaney, the custody of petitioner was given to his father, who abused his child in multiple incidents, and the state child services failed to take custody of petitioner eventually leading to the death of him (DeShaney v. Winnebago County Department of Social Services, 1989). While invoking the due process clause, the Court rule that the State had no affirmative duty to protect the petitioner (mother of DeShaney) under the Due Process Clause. The Supreme Court reasoned that nothing requires the State to protect the life, liberty, and property of its citizens against invasion by private actors and the Clause is a limitation on the State, not a guarantee of minimal levels of safety and security (1989).

Comment: Given its capital consequence, it seems any better of justice that encouraged the DSS to be more engaged with the follow up measure.

\section{Ross}

In Ross, petitioner was charged with the first-degree murder and an Oklahoma statute provides both parties in capital trials with nine peremptory challenges to prospective jurors (Ross v. Oklahoma, 1988). The fact that petitioner had to use a peremptory challenge to cure the court's error is not constitutionally guaranteed, but a state benefit as mere a means to achieve the end of an impartial jury. This Court has sanctioned numerous incursions upon the right to challenge peremptorily, and he received all the benefit that Oklahoma law allowed $\operatorname{him}(1988)$.

Comment: Given the crucial role of jury system in our constitutional tradition, the state has some of unavoidable duty, and would not be a benefit as to excuse itself with the neutrality defense. 


\section{Hamilton}

In the Hamilton v. Regents of the University of California, the Court upheld the "right of California to force its university students to take classes in military training" and reiterated the public education is a state benefit not to be argued relating with the constitution guarantee of equal protection or religious freedom (1934). The traditional adherence with the concept of vested right eligible to seek a strict scrutiny of enhanced protection and state autonomy interwoven with the strong sensibility of restrictive federalism had been reinstated. While the court found that the University of California constituted a corporation created by the state to administer the University, its president, and its provost, and as held is a constitutional department or function of the state government and as such an order by the regents is in effect a statute or law of the state, it endorsed the scheme of state law, as quoted "in order to devote to the largest purposes of education the benefaction made to the State" and "students at large, shall receive instruction and discipline in military tactics in such manner and to such extent as the Regents shall prescribe, the requisite arms for which shall be furnished by the State (1934)."

Comment: the student's duty within the disciplines and frame of university's academic curriculum and would be the kind of contractual essence as inviolable, but the dispute involves an equal protection with other similarly slimmed religious people.

\section{Randall}

In Randall, solely because they refused to subscribe oaths against the unlawful advocacy involving the protection of federal government as specified in the state act, appellants were denied tax exemptions provided for veterans by the California Constitution (Speiser v. Randall, 1958). The filing of such an oath was required by a California statute as a prerequisite to qualification for the tax exemption. The Court held that the enforcement of this provision through procedures which place the burdens of proof and persuasion on the taxpayers denied them freedom of speech without the procedural safeguards required by the Due Process Clause of the Fourteenth Amendment (1958).

Comment: As Wald commented, it shows that the traditional concept, such as burden and benefit or rights and privileges had over time actually lingered and not was treated in any definite ordains.

\section{Sherbert}

In Sherbert, appellant was discharged by her South Carolina employer and was unable to obtain other employment because of her religious belief, and her faith (Sherbert $v$. Verner, 1963). While the State Commission, as the State Supreme Court endorsed later, denied appellant's application on the ground that she would not accept suitable work when offered. The Supreme Court held that, as so applied, the South Carolina statute abridged appellant's right to the free exercise of her religion, in violation of the First Amendment, made applicable to the states by the Fourteenth Amendment.

Comment: Same as Randall.

Maher v. Roe 
In Maher v. Roe, the Connecticut Welfare Department issued regulations limiting state Medicaid benefits for first-trimester abortions to those that were medically necessary (Maher v. Roe, 1977). An indigent woman ("Susan Roe") challenged the regulations, but the Court, in 6-3 decision, held that the Connecticut law was rationally related to a legitimate state interest and distinguished between direct state interference with a protected activity and state encouragement of alternative activity consonant with legislative policy (1977).

Comment: the protection of indigent woman involving a basic biological aspect seems tantamount to the kind of universal right of positive liberty that the Supreme Court may not be stringent to afford its status.

\section{Harris v. McRae}

In McRae, the court approved the elimination of abortion from publicly funded health care programs even where a pregnant woman's health is gravely endangered or she is pregnant as a result of rape or incest (Harris v. McRae, 1980). The decision was reached by a sharply divided Supreme Court decision, and ignored the lower court's comprehensive findings of fact as well as the principle that the state must respect the constitutional rights of the poor in distributing or limiting welfare benefits. The four dissenters each wrote acerbic opinions adopting plaintiffs' arguments that the state cannot rationally protect fetal life at the expense of women's health and that the discriminatory funding of abortion and childbirth impermissibly invades the decisional rights of poor women (1980).

Comment: the historic decision of Roe on the right of abortion likely had been entangled with the crucial contention of this case, but the dissenter's view of equal treatment between the abortion and childbirth seems appealing. Most basically, the kind of standard is deeply advisable to comply with given its inseparable nexus with the liberty of women as same with Maher v. Roe.

\section{Selective Service System v. Minnesota Public Interest Research Group}

In this case, the part of the Department of Defense Authorization Act of 1983 denied federal financial aid to males between the ages of 18 and 26 who had failed to register for selective service. Applicants for financial aid were required to inform their universities that they had (or had not) registered for the draft. While the Court upheld the law, it reasoned, "since no student is compelled to seek financial aid, requiring an applicant to state whether or not he had registered for the draft would not be equivalent to forcing an individual to incriminate himself."

Comment: As Hamilton, I consider that various odds or contingencies of unequal situation have to be borne in prong and with comparative balance.

South Dakota v. Dole, 483 U.S. 203 (1987)

In Dole, the United States Supreme Court considered the limitations the Constitution places on the authority of the Congress when it commands to influence the individual states in areas of authority normally reserved to the states (South Dakota v. Dole, 1987). While sustaining the constitutionality of a federal statute, it ruled the Congress can legitimately withhold the federal funds from states incompatible with the federal policy of legal drinking 
age. However, it requires the criterion of constitutionally permissible exercise of spending power; (i) The spending must promote the general welfare; (ii) The condition must be unambiguous (iii) The condition should relate to the federal interest in particular national projects or programs (iv) The condition imposed on the States must not in itself be unconstitutional (v) The condition must not be coercive (1987).

Comment: As the issue involves a specific amendment of Constitution about national drinking regulation, it is distinguishable from other cases. It is a good case showing that the power to maneuver a policy addressee with funding chance could not mere a benefit since the funding law would create an protectable interest or expectation and its continued exchange could be an implied incident shifting a mere expectation into some extent of vested right.

\section{Lyng v. International Union, UAW}

In Lyng, the Secretary of Agriculture appealed the lower court decision that the Art. 109 of the Omnibus Budget Reconciliation Act of 1981 (OBRA) violated the appellees' associational rights and strikers expressive rights under the First Amendment, and violates the equal protection component of the Due Process Clause of the Fifth Amendment (Lyng v. International Union, 1988). The act provided that no household may become eligible to participate in the food stamp program while any of its members is on strike, or receive an increase in the allotment of food stamps it is already receiving because the income of the striking member has decreased. The Supreme Court reversed, and specifically illuminated (i) the Constitution does not require the Government to furnish funds to maximize the exercise of the right of association or to minimize any resulting economic hardship (pp. 364-368, 1988); (ii) it does not violate the equal protection component of the Due Process Clause of the Fifth Amendment, since it is rationally related to the legitimate governmental objective of avoiding undue favoritism in private labor disputes. The Court also rejected the argument based on the different treatment between the strikers and voluntary quitters and viewed that the neutrality concern does not arise with respect to the latter persons (1988). Additionally, the Court enunciated on propriety of deference to Congress in shaping the food stamp, and also adverted on the issue of fiscal integrity (1988).

Comment: Generally same with the concern of Selective Service System. One comparative note is that the divestment of right or privilege to the food program had effected on the family of strikers, nevertheless, the Court considered it as irrelevant since the Congress is plenary on this point. In some other constitutional terms, however, general safeguard not disadvantaging his family or his kindred because of an illegal action of person would have a place in the constitution that is surely a constitutional matter.

\section{Roth}

In Roth, one year contract professor at state university brought the suit claiming that (i) the real reason for his non-retention was his criticism of the university administration violating his right to free speech protected by the Fourteenth Amendment; and (ii) the university's failure to advise him of the reason for its decision violated his right to procedural due process (Board of Regents v. Roth, 1972). In an opinion by Justice Potter Stewart, the Court held 5-3 that Roth had no protected interest in continued employment, as he had completed his contracted term, and therefore was no Fourteenth Amendment protection (1972). 
Comment: Generally same with the Hamilton.

\section{McAuliffe}

In McAuliffe v. Mayer of New Bedford, a policeman received notice half an hour beforehand of a hearing before the mayor of a city upon a written complaint charging him with violating a regulation of the police department, and attended the hearing, but offered no evidence (1892). The municipal regulation provides that no member of the police department shall be allowed to engage in political activities. The Court ruled that (i) it is not unconstitutional as invading the rights of the members of the police force to express their political opinions; (ii) due hearing had been given him (1982).

Comment: the policeman would be duly required to be independent from political activities, but the due process of law seems unduly be reduced as slim on the part of McAuliffe.

\section{A Wald's View: Discussion and Insight}

As the pendulum already swung to influence the political or legislative minds, the judicial constraints on the traditional notion between the burden and benefit or right and privileges had simply seems embedded with a ripple of implicit course changing at occasions (Greenhouse, 1999; Wald, 1990; Williams, 2009). Given the inherent quality of judiciary, the attitudes could not be truncated in any simple frame as stupidly conservative, but with plausible contest as Wald churned had the Court would be blindly foregone abstracting other important constitutional points of consideration (Kim, 2014). His implication to point out a lack of attendance on the equal protection of analysis and faintly disreputable view on procedural due process might jeopardize a falsification of long adhered-with role of judiciary. Assuming if the important public offices are more paid and with pension compensation, it could be envisaged to draw upon the spirit and engagement beyond the neutrality excuse. That seems to be still worthwhile to argue even if the judiciary is passive nature of government branch. One most strong rationale--perhaps unique if for purpose to respond with the article of Wald--to support the governmental (or worse to include adjudicative as he argued) power as a neutral umpire would have a root basis from resources and financial tenet as limited and scarce (1990). It can allow the government, particularly the congress and executive, to generally limit the idealistic policy suggestion or public goal commanded from theories and philosophies. The failure to carry duly on sensible and socially congruent sustainability-- as argued from the equal protection and procedural due process-- through the delivery of justice could be alleged of bum rap -- a conspiracy with the Congress and executive-- or even malevolent omission of professional expectation held on the revered judicial branch. A view to ascribe on the formalistic dichotomy between action and inaction would be tantamount to judicial interment of social theory or progressive reality on the wake.

The challenge in this thesis would not involve with the kind of government largesse to require a costly expense of state or national institutions or public system, but possibly a grave potential of injustice among the harmed or deprived parties. Of course, the Court may perceive that the government would excessively be burdened if the Department of Social Service is constitutionally obligated to provide a due system to prevent the kind of deplorable 
death of Joshua (DeShaney v. Winnebago County Department of Social Services, 1989). The government may be disdained or consider to lose its integrity on public administration if to offer the food stamp to those whom do not conceive a faith of labor, but rather choose to run on the labor strike (Lyng v. International Union, UAW, 1988). The student seeking a benefit of federal loans should be such ethical or faithful-- so as to be integral with purposive ideals on the public benefit - that can statutorily be required to register his or her draft status. The students between the public education and his religious belief should have to comply with the regulation of state university on military education and course requirement -since he voluntarily chose that option and the state still has a neutral yardstick to pursue the public goals (Hamilton v. Regents of the University of California, 1934). The peremptory challenge to biased jurors have been marshaled in any fine categorization of statute, but was denied of its constitutional significance - because the state is a neutral administrator meaning the positive claim is not as a matter of right be granted (Ross v. Oklahoma, 1988). The Supreme Court in this case looked back on the wrong rejection of excuse for causes and rendered opinion as objectionable to rule on its constitutional insignificance - fortunately the Court considered an equity that the defendant was not actually miscarried since the challenged juror had not sit for his case - but still threatening a due justice to such awesome defendant without the service of full nine jurors (1988).

The entitlements or privileges are the benefit graciously rendered by the state or United States, in which the interested parties would have some legal ground to lean back, but highly unlikely be ensured as the vested right. The social pension for disabled and unemployed, veteran's benefit as well as retirement alimony would fall most notably within that class of provisional role of state. The area of concern would accurately lie at the core of legal and philosophical debate given the American legal realism stands on the idea of socio-economic nature of legal understanding. It is generally agreed that the law functions essentially to protect the reliability and expectation of right holders, hence, gives the standard of conduct on predictability and stability. The concept of vested right would be used relating with the kind of legal ideals. However, it would be a legitimate question if asking how the Supreme Court could so confidently be committed as austere and rigorous between the two concepts at this stage of social advancement. The concept is formulated as earlier even when we could not know the intellectual right of computer software and the trade secret was not a legal right to seek damages in the civil action. The traditional theory of state right in the international law now faces with new perception and reality that the majority rule would be a standard of practice within the kind of regimes. Given the international politics underlies to define vast quality of international law theories as most plausible to grant the extent of chaos, for example, on retaliation-- exactly the counter reality with the law and legal frame- the situation on the part of state must be viewed as more egregious or barbarian than the individuals in nation, who would be free, but must be subject to public power-perhaps government power on the Contractarian theory. The evolution in scope of modern public administration, I suppose, suggests two hints to weigh the right way of Supreme Court. I believe that the inaction thesis has less than bearing in consideration of massive or even spiritual subjection to the power of government while the traditional notion between the right and privileges had waned substantially--at least in active nature of branches--the evolving or emulating environment over history. Now we hardly return to the basics to begin with, say, the property right on chattel or land and estate or freedom of contract, which had long finely matched with the notion of liberal market capitalism. In this case, the contract is never the quality of Contractarian theory, which idealistically — but merely hypothetical—would be sublime with the intent of subjects - but practically coercive with no voluntary choice vastly 
in cases. There are a number of subjects and interested parties who could not begin with, rather the kind of inviting institutions or public laws luring the potential beneficiaries. Nevertheless, they are legally forborn from a reparation or retaliation unlike the state's in the international realm that the justice of government is a unique basis to restore their fortune. While the Fortune lists the superrich of nation, it is grossly depraving that the carriage of justice might be formalistic to stall on a legitimation of neutral or innocuous excuse. We had been aware that the public employees are superior, spiritually because they hold on faith and loyalty with the representative government. That is a unique asset of public employees with which the public employees only could be bought as their strength. A neutrality and dispassionate administration are such requirement necessary to deal with the private sector in terms of fairness and less interventionism. Provided if the government once intervened in the subject matter, is it permissible to bluntly step back, but with efflorescent package of public laws, but fatal with the intended group of policy addressees? The fairness and less interventionism need to be traced back to allow the government accountable to the public.

As Wald decried, it should be a "penalty" in the contemporary recognition, which could be sensible or the kind of inertia-possibly disguised as in Deshaney. If the normative leeway on the constitutional provisions were not attended or less in effect to bias the viable course of recovery, the problem would not only be hypocritical as Wald said-but may be illusionary over the public recognition (Wald, 1990). The European thought can be illustrated in two viewpoints (i) realism or neo-realism (ii) Say's rule "Supply creates a demand." The realism had as literally taken a focus on history and our experience as well as lesson that could ground more than practical perception of phenomenon. It tacitly influenced the American legal realism that requires the historic evolution and had a wake to interact within the liberal market and regulatory scheme. We generally view that the public revamp over the century had brought a paradigm shift and critical importance on the protection of vulnerable class--arguably requiring a similar extent of protection in the public benefit with the kinds of right since it is as much as indispensable while they are generally less intelligible or less affordable to buy the attorneys and so, at least initially. With a slight chance of procedure or weak formality on requirement, we may do injustice in the threshold of justice doorstep. More importantly, the Say's rule guide that the state would be a monopolistic supplier that generally abstracts the choice of subjects. That implies two consequences that "coercion views" claiming the evil of least option on the part of policy addresses on one hand, and that the subjects would have a growing awareness as same to the vested right. The reality may differ depending on the nature of controversy-for example the students on federal loans or state university regulation would be more on "coercion situation" while the Ross would perceive more on the "vested right situation" to unbiased jurors since the state law has such guarantee with explicit provision. Let alone the Beverage report or American cause for progressivism, my position can be countered on various grounds from theories and intrinsic of common law system or technicality, such as individualism judiciary or constitutional hierarchy over the state law. Granted with that possibility, I would be sympathetic with the view of Wald,

"The first is the American veneration of self-sufficiency and rugged individualism... The second, I think, is the desire to set limits on judicial intervention in the nation's affairs... at a time when the role of the state was highly restricted, there may have been some justification for treating a public benefit as a pure windfall,... Today...public benefits are no longer windfalls because we all depend upon them is, however, to tell only half the story...It also should be said that public benefits are not windfalls because we have 
earned them... Courts quite properly may place constitutional limits on this power without questioning the state's authority to refuse or even eliminate benefit programs entirely (Wald, 1990)."

\section{Lyng v. International Union}

In Lyng, the 109 of the Omnibus Budget Reconciliation Act of 1981 (OBRA) arose if it is constitutionally suspect. The Act provides that no household may become eligible to participate in the food stamp program while any of its members is on strike, or receive an increase in the allotment of food stamps it is already receiving because the income of the striking member has decreased (Lyng v. International Union, UAW, 1988).

Appellee unions and union members brought suit in Federal District Court, and the plaintiff prevailed on the finding of lower court that that it interferes with appellees' First Amendment and Due Process Clause of Fifth Amendment (1988). The Secretary of Agriculture appealed, and the Supreme Court reversed the judgment of lower court. The Court illuminated on three counts of issue which concern (i) the appellees' right with their families or the associational rights of the individual appellees and their unions (ii) appellees' right to express themselves about union matters free of coercion by the Government (iii) equal protection component of Due Process Clause of Fifth Amendment.

Somebody may argue on Dadaism as irrationality of civilization, but the brief here is never intended on the kind of Dadaism, given especially rude with the books or literature and more barbarian-like with the casebooks or court document. That is particularly taken that the common law system is on tradition and history as termed a stare decisis principle. I also would be true if the stewardship is shallow indeed in comparison with the majority court, but the court illumination would follow a short personal view.

On the first account, the Supreme Court illuminated that the Act does not prohibit individuals from dining together or associating together to conduct a strike, nor in any other way "directly and substantially" interfere with family living arrangements or workers' ability to combine together to assert their lawful rights (1988). In this reasoning, the assumption underlies that the participation of food stamp program is a benefit entirely malleable to the discretion of state, and no positive right to claim the food stamp. Given the current state of living standard and most basics of food in terms of human subsistence, we need to inquire if the nature of order does not support its human right status. The Supreme Court often resorts to the neutrality of state function which may, however, necessitate directing internally if the purpose is to discourage the union activities and perhaps a least nexus between the implied legislative objective and austerity of food stamp program. A most plausible rationale often would base on fiscal feasibility in align with this kind of challenge, but in this case, it is dubious if it could serve since the food program would be designed without a consideration on the number of disqualified beneficiary, at least initially. The Court also reasoned, "even if isolated instances can be found in which a striking individual may have left the other members of his household in order to increase their allotment of food stamps or left his union for that purpose, in the overwhelming majority of cases it is exceedingly unlikely that 109 will have any effect at all (1988)." This raises a survey issue on one hand, and could fit within the concept of public administration, which is questionable, however, if the informed workers would be certain as the Court expects. Because of its basic quality, the post-modern concept of public administration can be considered that should command with deep inquiries as if it penalizes the expectation of beneficiaries. It could be percepted as a loss of earnings 
within the time of experience and practice of institutions as Wald suggested. The Court also opined that the Constitution does not require the Government to furnish funds to maximize the exercise of the right of association or to minimize any resulting economic hardship. This view has a pertinence as later discussed on the staticism or federalism, the kind of passivism of judiciary and more broadly entire government. On the second account, the Court elicited, "rather than exacting payments from individuals, coercing particular beliefs, or requiring appellees to participate in political activities or support political views with which they disagree, 109 merely declines to extend additional food stamp assistance to strikers simply because the strike has caused a decline in their income (1988)." This again brings an imagination if the state is a behemoth of building up the public system with the excuse of neutrality and thesis of dispassionate player. The benefit $\mathrm{v}$. burden dichotomy has mechanized the way of consideration. Nevertheless, it raises a self-contradiction that the relation can be penalized on give and take notion, very private with no bearing of public neutrality and economy-centrism. It is logically perverted if the state is a neutral umpire of market and, hence, their income decline. It is also not coherent if the government is expected of utilitarianism on neutrality and generality, but the focus is narrowed specifically on the income of union workers in contrast with universal right against hunger or starvation. The Court also endorsed the traditional classification, by ruling "the Constitution does not confer an entitlement to such governmental funds as may be necessary for individuals to realize all the advantages of their right to free expression (1988)."

On the third Count, the Court found that "it is rationally related to the legitimate governmental objective of avoiding undue favoritism in private labor disputes (1988)." The state is a legitimate entity to pursue the public goals and has a good reason that it needs to avoid undue favoritism in private labor disputes. Nevertheless, it is questionable if it favors the employers by withholding a statutory food stamp relationship. The neutrality is a subtle concept bearing with inaction, but skepticism arises if the prescription of food stamp program and exclusion of certain scope of beneficiaries would apparently be inaction. The Court utilized the passivism tenet of judiciary by illuminating "although the statute does work at least some discrimination against strikers and their households, this Court must defer to Congress' view that the disbursement of food stamps to such persons damages the program's public integrity and thus endangers its legitimate goals (1988)." The Court again introduced a neutrality concern between the strikers and voluntary quitters, and specially elaborated on " 109 's provisos preserving prestrike eligibility and eligibility when a household member has refused to accept employment because of a strike or lockout (1988)." The union is social institution tacitly with an applied notion of developed ego that the nature of order would be disagreeable, hence, partly the question of ideology and seen to be in need of more on Wald's "penalization view" or "genuine neutrality." There are other points, in which the Court perceived the primary responsibility of Congress on the national fiscal administration and the policy design on food stamp program is a matter of statute, not constitutional controversy (1988).

\section{A Perspective on the Role of Court}

As continued, the criticism of Wald has a place where the legal theory crosses. His thesis of unconstitutional conditions obviously counter-poses a decried protection on the Fourteenth Amendment of due process clause (Wald, 1990). Really behind the scene, the traditional contrast between the natural law and positivism tenet of legal philosophy had impliedly been underlain (Budziszewski, 2009). Wald's view is likely to be any positivist's 
while urging an active resort to the Amendment, but beyond that, since he now struggles to search a normative coming -- in my sense, faith and repatriation to the clause itself -- on the prescription of Amendment. The majority tendency -- arguably disagreed even by justices of ruling opinion and between his wordings of frame, such as benefit $\mathrm{v}$. burden, right $\mathrm{v}$.

privileges, and action $\mathrm{v}$. inaction - can, in this purview, be perceptive of naturalists, at least, in the sense of unconstitutional conditions as Wald ascribed (1990; Van Alstyne, 1968). The kind of conceptualization would not be traced with any express language of constitution, but would be a judicial invention as inculcated in multifaceted influence from the evolution of history and impact on the minds, sensibility as well as intelligence of common law judges. One may argue that the judges are a law making body for the art of terms to be ordained with the case laws. Nevertheless, it is still the structure, at least, in the countries of written constitution under which his conscience, judicial talent, and legal knowledge can be played out as not in contradiction (Greenhouse, 1999). Then, discrete situation emerges on the justices and, in face with the challenge of opaque or ambiguous command of Constitution, would drive the common law judges in two options of predicament. First, he would subscribe to the order of nature so as to engraft the difficulties of reality with legal theory. Second, he may skillfully become shrewd exercising his factors of circumstance -- adversary system and equities of disputing parties, passivity tenet, evidence or procedural rule and so -- most importantly in the end of integrity of case laws and to be made not in contradiction of venerated case laws.

Then, the old gifthorse emanates three implications, one that it should not be a horseshit to collapse the religion of case law intricacies bringing the kind of nobility ethos everybody aspires. That is surely the role of law and importantly undergirds the rule of law ideals for certainty, predictability, and stability. Other odd may be that old gifthorse may no longer run to be blocked by rock and stone of neighborly conditions (Maher v. Roe, 432 U.S. $464,1977)$. The old gifthorse, finally, may be diagnosed enough ill to undergo operation that could reinvigorate his ability to run. From various grounds crept into the reality of judiciary, the third aspect could earn any probability that the space of improvement possibility could be searchable in any way. While Bickel endeavored on the revered or practical superiority of judiciary dealing with the difficult constitutional agenda of nations, the forum is, in no direct relation with representative democracy, only but selected few marines and unelected officials. That does not say that it is neither undemocratic institution nor lacks a legitimacy. They are duly appointed by the President who is elected by the people. The consent of people enabled the Constitution to be supreme law of land and the basis of state or union power in which it takes a chapter, namely, Art. III. Rather than lacking, the centuries of national practice had been guided, in genuine sense, and illuminated by the role of that very branch, which perhaps should be the generator of legitimacy to rule the nation (McAuliffe v. Mayer of New Bedford, 1892).

The legitimacy generally stems from the majority rule, hence, head count, but that is never truly such given even number of Senate for states regardless of its populace and indirect mode of election on the Presidency of nation. The legitimacy even arises from hereditary monarchy in some countries, if merely symbolic. In the quibbling of event dealing with the dispute, they would be highly minded and prepared to interpret the wish and aspiration of people that we never could say them somehow the kind of selected few or modern nobility. At least, in this sense, they are, hence, the institution itself, would never be ascribed as of undemocratic nature, and we generally retreat from asserting its inefficiency or disutility that the nature of work could be best responded with that mode of engagement. 
Truly that could apply to the Congress that the senators or representatives would be seen proper to be insulated from the people once chosen. That is general theory to functional or deliberative democracy and underpins the assumption of modern democracy. Therefore, the trajectory of our legitimacy structure would have a wake over history, at least impliedly, by penetrating the kind of elements, say, old and modern wishes of nobility, economic statecraft or even ideology, plutocracy thesis of nation, as well as modern professionalism for politicians and ruling elite generally.

The natural law theory was once rejected by the Supreme Court as earlier with a case law that the modern jurists in practice generally do not adhere with its binding effect on the adjudication (Budziszewski, 2009). Therefore, the kind of concept would be discussed in the academics or the kind of soft element to inculcate jurists and permeated in the rules or judicial theory impliedly associated with the positive laws. That element, hence, now overwhelmingly plays within the dimension of humanity or social exposure and education of law makers, if judges or legislators, but could only be ascertained through the positive laws-they eventually created---for the law searchers. This can be shared with the last comment of Wald, "That, I believe, puts upon you, the academics of our nation, a heavy burden that judges cannot share; to step back and take the long look, risk the odious taunt of digging up old and lost causes rather than launching the brilliant theories, retrace steps that should not be taken in the first place (1990)."

Over the work on professional responsibility, they use the kind of tools or mechanics with such substantiation that we now question of their skeptical use, perhaps, as unfettered or dormant. How do we justify the kind of classifications? The right would be the kind of evolving concept as we see the soft elements of natural law concept, which would be a historic and intelligible creature. How do we perceive the benefit v. burden given the primacy in theory or assumption between the state and individual. Given the individual goes upfront, is it merely a benefit to ensure the safety of poor Joshua (DeShaney v. Winnebago County Department of Social Services, 1989)?

That is never a state-centrism indeed if we deal with the crucial importance of human rights in modern constitutionalism. Ironically, the German positivists would have more a worship of human rights ideal and international peace than the common law countries, at least, in the language of Constitution itself. The difference may well be traced between two UN declarations of human right -- a vast twin with that or France's -- United States Constitution. Furthermore, a conjecture would not disappoint us given an array of German spirited constitutions within the global jurisdiction. I never say that the reality would differ given the kind of convergence theory of comparative law, and we see the same nature of dealings about the abortion right in 1970's jurisprudence of both countries. I also may not be imprecise if the delicacies still exist, exactly the point we now concern with our line of cases and view of Wald. For example, I am dubious if the "right to be forgettable" in the internet space would be held as strongly as ECJ in the US. That would also be if the rhetoric of one justice in our cases could stand, "the state is not constitutionally obligated to offer the parole service" The jurists of both countries, though generally positivists as led from their profession, are certain to find any oasis of nobility for the people with the kind of legal ideals and equity of parties. Nevertheless, the general tendency would seem less fitted and imperfect to yield delicacies, if we are termed with the labor right and sense of duty to positive liberty and the enhanced role of state to administer due constitutional objectives. It may not be wrong to taint 
court rulings over the trend as Wald said, "while refusing to undertake even the minimal reciprocal gesture involved... (1990)"

As known, the Amendment had a strong history that remains at the cutting edge of constitutional thought, and enlarged the kind of universal concept of human right (Vile \& Menez, 2010). It is liberating on one hand, but threatening the state while the formalistic nature of judicial dealings had been practiced before its enactment. Technically, the Amendment can be perceived as such, in which the universal human rights and extent of federalism crosses. It could be a kind of basin that the humanity and social congruence could be created or expanded, but on the condition of staticism or federalism. This would pose challenges not merely with the natural law or soft elements, but, in essence, the kind of legal question that Wald precisely pointed out in his exertion. That is the point deplorable more than other angles, but it has the quality that nobody could be complete or perfect with any definite say of best rules. Only could it be possibly stated if the justices would respond with the condition of staticsm or federalism, but should not be on the unconstitutional conditions as Sullivan elicited (1988).

In respect with this viewpoint, we would be driven to inquire ourselves between the action and inaction if the judicial theory could recognize inaction within the criminal province of actus reus requirement. Given the Good Samarian law implies, the nature of order would require a rescue action for the already initiating parties that can create the skepticism. The students might be duly disposed that he could be protected both from the studentship and the liberty cause of nation eloquently announced by the Preamble other than minor print of school regulations if he is a conscientious objector (Hamilton v. Regents of the University of California, 1934).

We can be reflexive to weigh whether an indigent pension beneficiary could be dispensed with less than attention in contrast with gold mouth of right holders. Given the jury trial comes in comport with the nature of order, we might be less honest to make it mere a benefit of state--without an engaged consideration on possible expansion of constitutional language--than any fundamental rights (Ross v. Oklahoma, 1988). That would create a greater risk if he or she could possibly be convicted of capital crimes and punishment. We also would retrospect if the rationale can sustain to comport with the natural order that the deprivation of food stamp is permissible through the family because of participation in the labor striking merely because the federal statute has that usual frame of enactment. Despite these, we could well be concerned that there exist a plethora of other grounds on the part of majority opinion. Vastly on the majority view can we find the difficulties and challenges arising from the attribute of judicial branch or basics as sketched above. The ideals of law, such dichotomy between the natural law and positivism, selected few of nobility -- never sensed in negative connotation in my case because they act to ensure a nobility of people--had been intertwined with our subject matter between the universal concept of human rights and with the staticism or federalism. Hence, the question can lead us to immeasurable amount of debate, but I expect that it can be focused on the staticism or federalism, and the public officers generally. What is the nature of state or United States as a state? Simply could we find a polity or politics with the democratic process or benevolent King into the state on one hand, perhaps a general understanding of westerners. One, perhaps oriental, may be simpler who ascribe the puzzle, "which is first between a hen and egg as if applied to the relation between the individual or state?" We can be reflexive if the rigged individualism has to surrender to the staticism or no sanguine federalism so that we have gone too far with the 
state idolism of neutrality and superiority or insipid institutional balance between the federal union and state autonomy (1990).

\section{A Suggestion}

One episode has now stroke the Korean society that one suicide business man had bribed the vast number of influential politicians and key public officers. One political scientist posted a newspaper editorial accusing the Korean politics as kleptocracy. The notion would never be positive or desirable in normal use of term, but the morale can be drawn upon the attitude of kleptocractic public officers and, of course, with no bribery. I, hence, suggest professionalism as an alternative to complement with the staggering and history long behemoth of institutions and systems, as well as the old gifthorse. I would be implied of Handel's Saraband, in which the nobility -- modern replacement of public officers -- would resort with their scenes and enjoyment, but their due feel of self-identity with the state. Fortunately, the state at that time would even not be neutral that we may feel safe, at least, from arbitrary ruling. Behind such comfort and enjoyment, they probably should from time to time be attentive to practice a warrior duty for protecting their privileges. Now let us turn on the Bizet's, in which the socially deprived class of people manages their fate and enjoyment. I may hopefully expect to draw upon our illustration of classic music if the public officers are situated privately and on his public duty. Then I may suggest why we excuse ourselves to come lazy in stealing our neighbors. Why don't we put ourselves into the shoes of Joshua, Ross and his replicas, Roth, Lyng and so? 


\section{Reference}

Budziszewski, J (2009). Written on the Heart: The Case for Natural Law, Downers Grove. Illinois : IVP Academic

Kim, Kiyoung, The Separation of Powers Principle: Is it a Lynchpin or Pushpin for the Voyage of American Public? (August 1, 2014). International Journal of Advanced Research (2014), Volume 2, Issue 8, 887-895. Available at SSRN: http://ssrn.com/abstract=2573560.

Greenhouse, L. (1999, January 14). Supreme Court hears welfare case. New York Times, p. A14.

Sullivan (1988). Unconstitutional Conditions, 102 Harv. L. Rev. 1413.

Van Alstyne (1968). The Demise of the Right-Privilege Distinction in Constitutional Law. 81 Harv. L. Rev. 1439.

Vile, J. R., \& Menez, J. F. (2010). Essential Supreme Court decisions: Summaries of leading cases in U.S. constitutional law. Lanham, Md: Rowman \& Littlefield Publishers.

Wald, P. M. (1990). Government benefits: A new look at an old gifthorse. New York University Law Review, 65.

Williams, C. J. (2009, November 19). Gay couple win ruling; A federal attorney is to be repaid the costs associated with his husband being denied healthcare coverage. Los Angeles Times, p. A6.

Board of Regents v. Roth, 408 U.S. 564 (1972).

DeShaney v. Winnebago County Department of Social Services, 109 S. Ct. 998 (1989).

Hamilton v. Regents of the University of California, 293 U.S. 245 (1934),

Harris v. McRae, 448 U.S. 297 (1980).

Lyng v. International Union, UAW, 108 S. Ct. 1184 (1988).

Maher v. Roe, 432 U.S. 464 (1977).

McAuliffe v. Mayer of New Bedford, 155 Mass. 216, 29 N.E. 517 (1892).

Ross v. Oklahoma, 108 S. Ct. 2273 (1988).

Sherbert v. Verner, 374 U.S. 398, 404 (1963).

South Dakota v. Dole, 483 U.S. 203 (1987).

Speiser v. Randall, 357 U.S. 513 (1958). 


\section{$\mathrm{X}$. The Judiciary and Interpretive Issues}

\section{Briefly on Interpretation}

The interpretive issue arises when the language or terms are ambiguous. It requires the judiciary should be wrought on additional entanglement with the text and amendments to seek a right principle and understanding of constitutional mandate. It normally is susceptible of heretical pluralism involving the area of concerns and controversies that we are often countenanced with a plethora of dissenting or separate opinions (University of Missouri Kansas City, 2009). The interpretation of statute, notoriously the Constitution of United States, has been considered an inherent judicial responsibility to provide a plausible meaning when the ambiguities arise of what the provision actually mandates as a rule in resolving the dispute. The power to interpret by judiciary often is viewed with a creative power as contrast. That is proper in the sense that the legislative creates a public policy by enacting the statute. Then, the executive enforces the acts and has a cabined scope of creative power with delegation or by filling the gap of statutory provisions. In that sense, they are vastly implementing agencies, but with such a creative domain. Nevertheless, three branches are exercising an interpretive function commonly in the order to respect the Constitution let alone the kind of judicial finality or judicial control of norms. The interpretation, in normal operation, presupposes any written object that is deeply enshrined in our psychological and intelligent domain within the mind. It contracts with the internal order of human agent that had contributed to civilization. When we read the books or articles, we can be implied with some process of interpretation to reach the message or ideas that the authors intend convey. A vast of our intelligent work would be based on the interpretive function showing its primacy in unearthing the truths. For example, the scientist begins their work with the literature review and identifies the flaws or insufficiencies of existing theory pushing to frame their research questions. Even for the natural scientists, the first task on his professional research would identify the current mainstream of theories-so requiring the interpretation of prior research findings-- that has to be responded with or torpedoed by his own outcome. Then the remains for a truth finder or developer perhaps could only be the kind of pure discoveries or related with the ground theory of qualitative researcher, which generally is not a work of courts.

\section{Strengths of Court}

The same sort of process had long been undertaken by the Courts in the United States as they entangle with the language of Constitution, statutes and regulations as well as the court precedents (2009). The strengths would underlie its enriched tradition and method of raveling the constitutional truths as supported with the kind of vast supportive documents and their revered rule, say, stare decisis. The experience becomes stretched with a stack of previous views or court decisions to safeguard against the ungrounded quandary of interpretation. That is impliedly habituated within our routine work or engagement allowing other branches generally unrivaled. This presents a scene of subtlety that the two other branches may firstly diagnose the policy challenges or demand of environment before they begin an interpretive work on the relevant provisions of constitution or statutes. Moreover, 
they might not be thorough to complete with tackling with the norms which they are bound by. It would be unlike the judiciary because of the nature of responsibility. They may even be embraced with the reform or progressive professionalism although the judiciary often has nothing but to be conservative centering on the Constitution. Despite the attributes, the methods and approach of judiciary are regarded as precious to provide a certainty, stability and predictability so that it could align its talent and capability with the interpretation of statute--most decisively involving the Constitution. The judiciary is comprised of professionals on law, who are normally equipped with the case law knowledge that is generally inconceivable without an interpretive understanding of case laws and statute (Vile \& Menez, 2010).

\section{Limitations of Court}

I suggested two strengths that stem from the rich tradition of case laws and educational background for the judicial people above. The limitations would arise if the Constitution requires the kind of endeavor to meet challenges and demand of transformative community. Then the judges might be compelled to exercise their responsibility like the researchers on ground theory or discovery mission of milky way. The inductive reasoning would be a usual way on their journey, but turns merely as stylish so as to be already saturated with the intent to invent new theories to cope with (Glendon, Carozza, Picker, 2006). The inductive reasoning may be proselytized, but the internal mind of judges might be full of intent to alter the kind of piecemeal revamp over history to invite a new rule. The kind of situation would be more prone to occur in case where (i) the constitutional language is ambiguous and (ii) the community challenges or reformist tense soars to demand a revolutionary turns of new rule. Then he could rather choose to think with a top down nature of approach in the shoes of creator with a less reliance on possibly odd or outmoded holdings of prior court. Although they are not apparent with deductive reasoning in the court opinion, they internally adopt it as a creator. We may, in reality, call them either radical constructivists or originalists - depending on the finally desirable finings. Although we often call upon the former in this kind of challenges, this suggests that the wisdom of common law judges or new rules could even be shaped to most preference of hundred years of antedated rule, so to speak, the originalist positions. This also hints that the intelligence in the domain of humanity and social science would be neither automated on progress nor certainly steady and gradual. This would be unlike the natural or engineering science, and might not fit with the absolute evolutionism. In other words, we may not use a lower version of computer, but still could avail of a greater idea from the older cases than the most recently disposed.

Nevertheless, it might impose an overburden on judiciary provided if the language of Constitution is clear and straightened to leave no leeway for the judges. In exacting sense, it is not merely overburden, but a kind of transgression to fail their job responsibility that the judges betray the plain language of Constitution. The unique possibility for judges to respond with this predicament, then, would be to urge on a legal reform or constitutional amendments in dictum. Therefore, I may infer two limitations arising from (i) general tendency of "semantic captive" or plain language rule in interpretation and (ii) general weakness of judicial conservatism on stare decisis or inductive reasoning and institutional attribute.

Comparatively in law, I suppose that the limitations would also be present in British and French traditions, meaning that they do not readily follow the societal change at the same extent of resilience, but for other background. In the British case, the conservatism would 
heavily be toned with the stare decisis since they have no written constitution (2006). In the French case, the judiciary is an extent of feeble institution generally submissive to the will of political branch. The United States would not be improper if even to ascribe the egregious judiciary on the case of dilemma--such as second amendment right to bear arms--as the kind of "slave of constitution." If normative supremacy were to be abandoned in the socialist ideas, we may satire them a "slave of politics or ideologies," but with some insight to prevent an undesirable and unilateral inculcation of semanticism and history mania on case law integrity.

I may suggest that in combination of deductive reasoning and courage of public spirit, the kind of limitations can be repelled to bring a progress particularly if the language of constitution is ambiguous or susceptible of pluralistic views and if the challenges are notable with new deals.

\section{On Method and Theory}

Given the method of judiciary has been stated, I may be disposed with several aspects if shallow. First, the Kantian theory between the dimension of reason and empirical experience may arise as pertinent for constitutional interpretation (Kant, 2008, 1). Hundreds of case law had steered the fate of disputed parties and stood as a law of nations in which the empiricism and inductive reasoning permeated to shape a principle and legal theory. In case where ambiguities arise with demanding new laws, the strand of ration or reason could take a lead to rebel at the extent of conflict. More in finalization as Pardo and I could illustrate, the critical third way may be built-in to seek a truth of practical reasoning and judgment as Kant evinced in his two treatises, which guide on a new frontier of verity between the empirical world and human agents (Kant, 2008, 2; Kant, 2002). This could help to overcome orthodoxy between the orginalists and constructivists, which allows to earn the plausibility and persuasion that the judiciary long had taken as a way to the harbor of intelligence. My reinstatement of this point, however, could reinforce the dormant judiciary to be alarmed with the new challenges, at least if rescuing a conservative fallback as "semantic captive." Second, scholarly support, for example, such as constitutional theorizing as wrought by Pardo on the fifth and fourth amendment, would gear up with more enlightened deals with the ambiguities of Constitution. Once I mentioned the law professors of Germany are more an important engine to guide the legal intelligence while the courts might be more a revered basin of legal intelligence within the common law system as ours. In the area of ambiguous legality, however, theories generated from a theme of realm by law professors could be superior to resort with an implied deductive reasoning in combination of constitutional language, as Pardo structured, "My approach is a middle way between the two dominant method for constitutional theorizing in this area,...Section II describes the core features of the doctrine for each amendment... Section III, after first discussion the shortcomings of alternate views, presents my view of the relationship between the two amendments... Section IV turns on the theory back on current practices by using it to critique three current doctrinal problems where both amendments are implicated.... (2005)." Although he termed as in the criminal procedure, his two traditional ways seem to reflect similarly between deductive and inductive reasoning while presenting, “....typically takes one of two forms, which might loosely be characterized as normative, prescriptive, or revisionary on the one hand and positive, descriptive, or explanatory on the other (2005)." His method employed a third approach-hence not deductive in this sense--which would, however, be applicable to the evaluation of court rulings within his frame. The Court may get busier than scholars since their merit is related to make it primate with the equities of party, which, nevertheless could be complemented with 
the scholars' contribution. In 2005 decision, the comment of Justice Scalia had a satire of this subtlety, "It is indeed a wonderful new world that the Court creates, one full of promise for administrative-law professors in need of tenure articles and, of course, for litigators" (National Cable \& Telecommunications Association et al. v. Brand X Internet Services et al., 2005). Then it has been helpful to the Court who will revisit three problems of transposition as Pardo illuminated---arguably inconsistent and overlapping miscarriage of Fourth and Fifth Amendment jurisprudence---subpoena, stop and identity statutes and prearrest silence (2005).

\section{Cases and Thought}

I may illustrate some of problems that arguably are entangled with the ambiguities of constitutional language.

First, the eighth amendment prohibits the excessive bail or bonds as well as unusual and cruel punishment. The Court began to engage with the death penalty laws of state since 1970's while the case laws had still been disputed whenever the challenges arose. I am not any one sided with a full advocacy between the abolitionists and maintainers group. Hence, the Court has done well and been proper to respond with specificities of challenge, for example, substantive due process of laws and proportionality principle of sentencing, or execution of mentally retarded or minor (Atkins v. Virginia, 2002). That would be the strength with enriched traditions of case law. Nevertheless, we could raise a concern if the Congress would enact a uniform law on death penalty if not in conflict with the constitutional federalism. With the phrase and historical reality, the Eighth Amendment would be incorporated in relation with the kind of militia or instability of warrior conflict, which justifiably disregards its entire abolition. Nevertheless, the environmental change, especially from the international initiative and accomplishment of science, could legitimate a quantum leap for abolition of death penalty. The kind of alternatives could be brought to be related with the strengths and limitations of judiciary.

Second, the right to bear arms will certainly be one of painful controversies, as Obama lamented, "it is irrational and insensible to deny a uniform federal response for security of our neighbors." My sense is if the justices vehemently protected its primacy over various cases despite a soaring demand of rigorous regulation or entire disentitlement unless militia actually would be present. The controversy can be stated showing the limitations of judiciary most starkly (District of Columbia v. Heller, 2008). While the gun control act gradually becomes tightened and more regulatory, others may raise if the present status may be same or similar with other countries, on which I generally would not agree.

Third, the ninth amendment and right to privacy would be a graceful protection of Constitution that the case laws may flower to provide a due extent of liberty and education of people between the private and public cross-section. In so doing, the court role in this area seems very strong. However, the case laws would not always be succinct to challenges, but fluctuate to create resilience at extent and varying with the changing courts (Grutter v. Bollinger, 2003). The development of technology and science also stimulate a new way of privacy concept that the judiciary should be vigilant to supervise. Nevertheless, it entails the difficulties and challenges where the Court often defers to the agencies, for example, as Brand $\mathrm{X}$ in 2005 involving net neutrality issue, with expertise and enriched experience on that specific field. One may argue if the abusive use of deference rule can lead to a feckless 
judiciary provided that the forum is any most adequate to deal with square points of consideration on humanity, social congruence, ethics and morals, and our reality of public lives.

\section{In the Beginning}

The local campus news aired that one scientist in meteorology from Wisconsin, Madison earned an honor of nickname, "geek of weather" from pertinent agency, which program was prepared to enhance public relations with the title of Sky's the Limit. He seemed very proud with the nickname, but I am not sure if Justice Scalia would perfectly grin with the nickname, geek of originalism, or Justice Ginsburg would completely nod with the same of living document philosophy. That is partly because the philosophy, as a principle or belief, is some contra-taste from weather, but more importantly because the duty of justices tends not to be the kind of philosopher. In the mindset and basic disposition within professional personhood, the equities of disputed party would be more entwined to guide their way of practice. Nevertheless, the thought on philosophy, especially such important post of top judiciary in the nation, is never such futile, but of much use to understand the national judicial policy and ideals. It also is essentially related with the national politics as well as the understanding and criticism of standing laws. The context would be starker (i) if the distinct element of federal constitution and national frame of government has entangled to create various challenges and if the spirit of independence is such sacred to alter for liberation; (ii) new American venture for universal human rights and democratic rule has a wake of constitutional history (Vile \& Menez, 2010). Given its profound or even inviolable impact from such revolutionary consciousness, the American jurisprudence would even do not recognize the plain "rule of revision" other than amendment.

While European antecedents would still play on simple justification, "new law always alter old law," and the constitutional revision generally is deserved once the national consensus is to be reached in due mode. While the political consensus or majority rule still retains a continued primacy in Europe, that is subtle variegated in US (Kim, 2014). Under this backdrop, we normally ascribe the nation as judicial or law of nation. Nevertheless, the heritage of US laws had incurred a scope of protégé that many countries had learnt and actually benchmarked. The protection of minority right is one of safe haven that most people share to recognize and with routine expectation of legal or constitutional protections (2010). The kind of constitutionalism alters the political supremacy that a legitimacy generally could stem from the document embedding the hard nature of revision-if even not conceived in the US - and judicial review of legislation. The idea may be tasted as if we enjoy all-time list of classic music with the US constitution, which would practically be same with the constitutionalism of continental Europe, but from other basis. The constitutional scholars there have recognition that some crucial component of constitution could not be revised. And they generally have no recognition comparable with the concept of amendment. This week we are on some meditation between the originalism and living document philosophy (LDP).

\section{Originalism and Living Document Philosophy}

The orginalism can be described as judicial philosophy that the constitutional interpretation puts a prime importance to the intent of founding fathers, often faithful with the meaning of terms or phrases at the time of establishment as literally or historically searched and vindicated (McGinnis, Rappaport, 2013). For example, the literal originalists can lead to 
a limited constitutionality of right to bear arms specifically confined with the condition of militia with a focus on and literal receipt of provision. For the historical originalists, the right to bear arms must be based on the explicit terms of constitution, but can be respected with the accommodation of societal change. Therefore, the right to bear arms can be stretched, even in the peace time, justifiably with the self-defense concept since the original intent on historical reading would verify the crucial purpose of self-defense within the condition of militia. And expanded adaptation with peace time is not violable of the core intent of constitutional drafters because of the essence of Second Amendment.

For the advocates of LDP, arguably radical or modest constructivist, would emphasize the applied inference of constitutional meaning which should be liberated with use and application. So the Constitution can well be a political nature of norms beyond the supreme law of land. It is a central piece of national laws that is to be dynamic and adaptive to the environment and societal change as toned with the public lives of constituent. In this purview, the originalism can be more certain, generally leading to the conservative ethos and normative primacy on the faith of document and founding spirit (2013). Nevertheless, it can allow a due progress of society and expectation of public to be resilient and regressive. That might be the matter of extent since the judiciary primarily is commissioned to render a justice for the equity of parties, but possibly the kind of thought process incurring a practically different outcome. In the Second Amendment issue, only a sentence allows a critical need of massive gap filling work on thought and philosophical deliberation, in which the living philosophy generally will stand if with an engraftment of self-defense originalism, to say, in the face of public outcry, "we no longer can tolerate the kind of cruelty and inhumanity of gun shooting." The original intent on language and historical view certainly endorses a plausible ambit of amendment, but the living reality of public would not lend any absolute support except that the amendment is extant as a supreme law of land (2013).

In this philosophy, one would argue that law merges the living personality or would be gone to attribute it as the kind of "documentary fetishism." They may be more salient with historic originalism than literal or grammatical originalism if history may not be certain than the current reality and because of general decline of verity incompatible with the contemporary condition over the longitude of time lapse. It can vitiate the legal certainty than literal originalism, and the concept of self-defense may be crucially conceived, but merely implicitly grounding the justifiable space of constructivists. They also may argue from other angles that the orginalism has gone so farther-- to purchase unnecessary and wrong legal technicality forging to place the inadequate forms of law -- perhaps inadvertently. A selfdefense is a natural and criminal law concept that is never normally friendly with the relationship between the nation or state and individual. It would probably be odd if we view the right to be granted without the explicit condition of militia-- the kind of national condition to be concerned as a matter of constitution. Although the intent would be certain for the originalists which they should honor with every effort, the constructivists would be less than persuaded if we adhere with the apparent misplacement of tritely failed deals between the criminal issues of individual nature and supreme national public law--especially given its implied nature.

\section{A Perspective on Two Philosophies}

It would be a good example to understand the two camps of thought if we consider between the "revision and amendment." As introduced, the revision is hard to be conceivable 
that the forms were explicit with amendment once the bill of rights were incorporated as they are placed in the next part of seven articles of main text. That formality of deals would be considered in the aspect that the Constitution--the main text excluding the amendment in this case - is the legacy of the founding fathers and central identity of US democracy. That view is most powerful for a general understanding and compatible with the revolutionary frame of matters against the shift of government, which generally claims the universal and eternal quality before and after the incident. Kantian ideas of legal philosophy have a similar component in his thesis of eternal peace and constitutionalism, and the universal declaration of human rights would have same strand of spirit and absolutism (Allard, 2001).

The current theory on the debate of supreme power to enact or revise the constitution, often led by German constitutional scholars had intrigued on the kind of concept as inviolable and heavenly sacred that does not permit a revision. The "human dignity" and "right to pursue happiness" would often be categorized to represent the ideas of un-revisable scope, which also was pronounced in the preamble of US constitution. It can differ, however, that negative view on revision in the US basically is concerned of the structure of government, so to speak, distribution of federal powers, beyond the preamble. Although the preamble may not be revised, it would arguably be not certain if the original intent of founding fathers would preempt a revision of main text. That is particularly questionable if the original bill of rights had been attached only several months later upon the inauguration of Constitution. Such immediacy in time would negate any need of revision in normal sense. Their agenda also had been the bill of rights, which are sharply in contrast between the power of government and protection of human rights. There would, in high probability, be no need of revision, but merely the crucial need of expanded agenda. This situation could create a stylish uniformity on the formality of additional mention arguably not in direct conflict with the main text, and actually followed by later subsequent amendments now numbered at 27 .

Then the question may be legitimate if the amendment could contradict the provisions of main text or former amendments, in other words, if the amendment could repeal them beyond mere addition or clarification to complement with the main text. For example, many countries can reform their constitution from the presidential system to parliamentary one (Glendon, Carozza, Picker, 2006). That now exactly is one of research project explored by the Korean government nowadays--especially due to the perceived weakness of one time five years of presidency. Assuming if the original intent is opaque, the living philosophy can step in if the sequestration is serious to deprave the public lives -- normally nay present with the parliamentary government -- or when the consensus of Senate reform toward more popular democracy would prevail the nation. If the compassion and national feels of affinity would be strong as is, both camps would be happy with the static main text.

While German constitutionalism would be philanthropic or humanistic given such view on the inherent limitations of revision, the US has been political and state-centrism -- at least, in their understanding of constitutionalism (Rutherford, 2012). That also characterizes the US democracy as distinct despite the social and humanistic cause of French revolution beyond the expulsion of monarchy-however, several occasions of transformation between Republic and Monarchy historically. One point needs to borne, however, that the inherent limitations of revision can include the thought of state or politics since the constitutional revision is not permissible to alter the Republican form of government for the monarchy or communist state in Germany and South Korea -- the idea of defensive democracy. Hence, the issue also entails relevance with history and intellectual trait of different legal system 
although the structure of constitutions--in the order between the bill of rights and governmental power - is stark leading to the general dissidence between the US and German type. The originalism can take an expanded recognition that the subsequent amendments could not revise those of prior action. The living document philosophy may think otherwise. Assuming if they agree on non-repealability of prior amendments, the intellectual style or traditions would be implied of their view with the common sense and recognition concerning the intra-constitutional conflict (Glendon, Carozza, Picker, 2006).

\section{A Concluding Insight}

As briefed, the judicial philosophy of originalism and LDP entails much of particularities entwined with the independence and constitutional history, the sense of honorable solitude, legal ideals of law-typically common law, cognitive nexus between the law and public policy, and even intellectual trait of national engineers on the bench.

Within this frame of approach, we could not say that the originalism would be conservative and LDP-prone justices are progressive in any wholesale of our conundrum. One high-ranked judge once argued in his invited criticism of active judiciary from the viewpoint of clerkship judiciary. His message basically was that the Supreme Court over history had been unnecessarily busy with lengthy opinions eventually ending with a purposeless endorsement of liberty cause. In his ascription, the Court has historically been a greater liberator of humans - more in receipt, a deprived minority--to their due identity from the nature or heaven. Hence, the Court is thankfully realistic and has been special from other kind of liberators, neither religious than the liberating theology and on humans than the communist army of liberation from the imperialism. Nevertheless, we can counter if it is one other dogma simplifying the complicacies of challenge faced by the judges and justices.

For example, this means that the justices of originalism can argue more progressively on the privacy right depending on the characteristic of issues, who would work on the privacy issue or abolition of death penalty with any more generous grandfather than tiger mom (Atkins v. Virginia, 2002). Given the revolutionary sanctity and legal ideals, we may not be wholly disposed that oneness on the judicial yardstick should be contemporary or living as the LDP justices would propose (University of Missouri Kansas City, 2015). The controversies involved with a reversed discrimination or affirmative action could also possibly converge although the two titles can bear the kind of fundamental dissidence from the use of nomenclature itself (Grutter v. Bollinger, 2003). Facially, the LDP would be highly empowered to argue on the affirmative action while the originalists would likely be lost to derive a clue to support although he internally becomes resolute to support the action in his sensibility with the particularities of case at bar. That is because that the founding fathers would not acknowledge the kind of concept - "past wrong or recovered civil status of black people." He, nevertheless, may succeed in expansive view of liberty or equal protection by reading on the original intent, which could enable him to settle on the unambiguous constitutional language, but to enliven his belief of justice. Then the philosophy could be a useful tool, not merely a useless dogma, serving various purposes of judiciary-also intertwined with the legal academia - which is any more demanded than other public organizations. The justices would continue to weigh the merit and balance of cases on the kind of Kantian frame of thought process and constantly critique a false conception on "pure reason, practical reason and judgment" (Kant, 2008, 1, 2; Kant, 2002). 


\section{Reference}

Allard, J. (2001). Dworkin et kant. reflexions sur le jugement Bruxelles, Belgium: Universite de Bruxelles (2001).

Glendon, M.A. Carozza, P., Picker, C. (2006). Comparative Legal Traditions: Text, Materials and Cases on Western Law, Saint Paul. MN: West.

Kim, Kiyoung, Two Illustrations from South Korea and Some Reflections About the Public Administration Studies: Are We Granted to Pillory the Ethics or Social Justice? (September 2, 2014). International Journal of Philosophy 2014; 2(4): 48-59 doi: 10.11648/j.ijp.20140204.11. Available at SSRN: http://ssrn.com/abstract=2571903

Kant, I (2008). Critique of Pure Reason, New York. NY: Penguin Classics.

Kant, I. (2002). Critique of Practical Reason, Amherst. NY: Hackett Publishing.

Kant, I. (2008). Critique of Judgment, Amherst. NY: Hackett Publishing.

McGinnis, J. O., Rappaport, M.B. (2013). Originalism and the good constitution, Boston. MA: Harvard University Press.

Rutherford, S. (2012). Lex, rex, or the law and the prince: A dispute for the just prerogative of King and people. New York. NY: CreateSpace Independent Publishing Platform.

Pardo, M. S. (2005). Disentangling the Fourth Amendment and the self-incrimination clause. Iowa Law Review, 90(5), 1857-1903.

University of Missouri Kansas City. (n.d.). The Right of Privacy. Retrieved December 30, 2009, from http://law2.umkc.edu/faculty/projects/ftrials/conlaw/rightofprivacy.html

Vile, J. R., \& Menez, J. F. (2010). Essential Supreme Court decisions: Summaries of leading cases in U.S. constitutional law. Lanham, Md: Rowman \& Littlefield Publishers.

Atkins v. Virginia, 536 U.S. 304 (2002).

District of Columbia v. Heller, 76 U.S. 4631 (2008).

Grutter v. Bollinger, 539 U.S. 306 (2003).

National Cable \& Telecommunications Association et al. v. Brand X Internet Services et al., 545 U.S. 967 (2005). 


\section{The Rule of Chevron and Judicial Control}

\section{Red Lion Broadcasting v. FCC}

The Court in Red Lion decided on two cases in common interest dealing with the constitutionality of the FCC (Federal Communications Commission) regulation on fairness doctrine and its application on the Red Lion Broadcasting. A Certiorari was granted to the United States Court of Appeals for the District of Columbia. The Chevron rule might not be argued by the counsel, or be unnecessary to adjudicate since the Supreme Court had found enough ground to sustain the rulings of FCC. The Supreme Court specifically stresses the First Amendment right for the listeners and viewers as paramount than the Broadcasters given its ending consequence or massive impact on the large audience. They are duly subject to the regulatory measure of FCC since their right is not original to broadcast, but the fortune of being selected by the Government as a licensee. The rationale can be received in similar analogy that the universalism of international laws had an ideal to recourse the individual as an eventual end of ambit and purpose than the state, an allegedly unique or comprehensive object of legal being in the prevailing frame of that law.

The background of case is as follows (Red Lion Broadcasting Co. v. Federal Communications Commission, 1969). The Red Lion Broadcasting Company is licensed to operate a Pennsylvania radio station, WGCB. It carried a 15 minute broadcast titled with a "Christian Crusade" series. In the discussion of a book by Fred J. Cook, entitled "Goldwater - Extremist on the Right," Cook was personally attacked that (i) Cook had been fired by a newspaper for making false charges against city officials (ii) Cook had defended Alger Hiss and attacked J Edgar Hoover and Central Intelligence Agency (iii) he had now written a book to smear and destroy Barry Goldwater. Cook concluded that he was personally attacked and the dispute arose that the FCC declared that it constituted a personal attack and Red Lion had failed to meet its obligation under the fairness doctrine (1969). The FCC historically required a fairness doctrine to be respected by broadcasters in which public issues be presented and fair coverage of contending view or opinions shall be afforded. FCC ruled that Red Lion violated its duty of fairness when it carried a program attacking a person, named Cook. It subsequently ordered to send a transcript of broadcast to Cook and provide free reply time. The lower court upheld the FCC's ruling, and new rules were issued during the controversy concerning the personal attack and political editorials on candidacies for readier enforcement and with more specifics from the ruling. The lower court struck down the newly enacted regulation as adopted and amended. Two cases were consolidated for the review of Supreme Court (1969). The Supreme Court ruled affirmatively for the FCC on both cases, holding that "the history of fairness doctrine and of related legislation shows that the FCC's action did not exceed its authority, and that, in adopting the new regulations, the FCC was implementing congressional policy; (ii) the fairness doctrine and its specific manifestations in the personal attack and political editorializing regulations are a legitimate exercise of congressionally delegated authority. While sustaining the FCC's action in 1969, the Court found it not inconsistent with the precedents and congressional purpose of basic act (1969);

“(i) before 1927, the allocation of frequencies was left entirely to the private sector, and the result was chaos...(ii) Consequently, the Federal Radio Commission was established on the Act of 1927... (iii) A premature fairness doctrine was expressed by FCC guiding with the public interest as well as free and fair competition of opposing views...(iii) the fairness doctrine imposed 
twofold duty-- adequate coverage to public issues and fair coverage on accurate reflection of opposing views as supplemented, thereafter, with specifics, such as own initiative of programming.....(iv) the statutory authority of the FCC to promulgate these regulations derives from the mandate concerning public convenience, interest or necessity and consideration of the demands of the public interest in the course of granting licenses...(v) its authority is a broad one, a power "not niggardly but expansive"..... (vi) in 1959, the Congress amended the statutory requirement of Section 315 that equal time be accorded each political to except certain appearances on news programs, but within the spirit of public interest and fair opportunity of opposing views.....(vii) the 1934 Communications Act is not notable for the precision of its substantive standards, but the explicit provisions of Section 315, fairness doctrine and FCC rules at issue here are far more explicit than the generalized public interest standard...(viii) Although broadcasting is clearly a medium affected by a First Amendment interest, differences in the characteristics of new media justify differences in the First Amendment standards applied to them....(ix) Just as the Government may limit the use of sound-amplifying equipment...so may the Government limit the use of broadcast equipment.... (x) the chaos which ensued from permitting anyone to use any frequency at whatever power level he wished, which made necessary the enactment of the Radio Act of 1927 and the Communication Act of 1934 (xi) [it] has been the consistent view of the Court that Congress unquestionably has the power to grant and deny licenses and to eliminate existing stations...(xii) that provision-Section 315-which has been part of the law since 1927 Radio act has been held valid by this Court as an obligation of the licensee relieving him of any power in any way to prevent or censor the broadcast, and thus insulating him from liability for defamation...(xiii) freedom of the press from the governmental interference under the First Amendment does not sanction repression of that freedom by private interests...(xiv) licenses to broadcast do not confer ownership of designated frequencies, but only the temporary privilege of using them...In determining how best to allocate frequencies, the Federal Radio Commission considered the needs of competing communities and the programs offered by competing stations to meet those needs...(xv) the Court upheld regulations [chain broadcasting regulations], unequivocally recognizing that the Commission was more than a traffic policeman concerned with the technical aspects of broadcasting....(1969)"

\section{Thoughts on the Ruling and Chevron}

The market of broadcasting industry had greater potential to be monopolized on one hand and the scarcity of frequency could effectively eclipse freedom of expression for the actors with no such privileged status. Moreover, the broadcasting company with the influence of monopolization could be seen not dissimilar with the state as we assume in the theory of state action or originalism view of Constitution against the tyranny. Chevron rule requires two step analysis that (i) the statute is ambiguous susceptible of pluralistic interpretation allowing the discretion of public agencies (ii) the interpretation, albeit the rules and enforcement of public agencies, is not unreasonable to contravene the purpose of statute (Chevron U.S.A., Inc. v. Natural Resources Defense Council, Inc., 1984). Therefore, it is the 
concept interconnected with various public principles, such as separation of powers principle, judicial review of norms and paradigm of administrative state. In this purview, the expertise and experience of public agencies would be respected unless it is patently incompatible with the constitution and statute. That would also permit the breathing space of rule-making or implementing agencies in which the independent constitutional authority of Executive in executing the laws faithfully could be ensured duly with the spirit and tenet of Constitution. The Chevron rule tacitly shows the traditional thought of legal philosophy harbored around among the morals, religion, and laws (1984). The public policy and role of agency would be mostly crucial in respect of realizing the social justice derived from the public moral and utility (Kim, 2014). Hence, it can be placed somewhere in between the morals and law in terms of binding-ness, that the law will allow its leniency unless it would not directly and immediately breach the law. The Court, normally tasked with the bulwark of law and constitution, will defer to the decision of public agencies, normally tasked with the promoter of social justice. It is interesting that the Chevron rule may come into consideration within the area of overlap or interplay with other principle. The Brand $X$ posed a challenge whether the Court of Appeals should defer to the agency interpretation or maintain the ruling of prior case with the effect of stare decisis (National Cable \& Telecommunications Association et al. $v$. Brand X Internet Services et al., 2005). The Supreme Court had not upheld the opinion of Ninth Circuit that the Chevron rule would always trump given the statutory language is ambiguous. This raised a basis for the dissenting opinion filed by Justice Scalia that the court ruling can well lead to a possible derelict with a frivolous agency decision (2005). It would arise more seriously had the court sustained the agency action in prior cases. In his view, it can be viewed to undermine the basic structure of judicial control with the trade-offs of what? The majority view of that case would unlikely be immature so to be prompted with a reliance on the Chevron given the important status of stare decisis effect. Perhaps, the kaleidoscopic nature of administrative environment these days would infuse a ruling in practical aspect, and the niggardly tradition of tripartite system may have to balance the hand of Congress and Executive evenly with the Supreme Court other than lower courts. The ruling on that point is supple, but never raucous so that impliedly hailed the greater role of Chevron in contemporary society of technological advances (Shapiro, 1988). Paradoxically two cases involve the action of FCC which deals with the freshest policy areas on broadcasting and classification of internet service providers. Despite, the former case had not hinged on the Chevron while the latter case was disposed on that judicial theory.

In Red Lion, the Court had minded to survey the industrial history of radio and television relating with the major Acts and precedents. The technology still offers the ground element engrafted with applications and new mode of products, notably, the internet. The latter case reveals a similar line of technologies as well as the controversies of related business and market regulation. It is a subsequent court debate on net neutrality and interpretation of 1994 -involved with the rulings on classification between the information service and telecommunication service (National Cable \& Telecommunications Association et al. v. Brand X Internet Services et al., 2005). This area of public policy requires the kind of devoted agencies on prudence, experience, and multidisciplinary eyes on the specific field as a regulator of market. They could possibly trade off important constitutional values in the interest of efficacy, efficiency and one-sided growth creed for enterprises and national economy, which was responded positively in the first case, and with deference in the second case. As the Court reasoned, the fairness doctrine and important attributes of broadcasting -this point marks a difference within two cases although we may, in the future, should classify a few scope of information services in greatest public impact as a quasi- or broadcasting -- 
the FCC role could not be gainsaid in the attempt to argue on a holistic prototype of free expression simply because they act on the ground of governmental license and scarcity of frequency against other expressers (Red Lion Broadcasting Co. v. Federal Communications Commission, 1969). The issues at bar bring two typical problems of personal attack and political editorials on candidacies. The administrative measure coercing to respond with the provision of free reply time against attacked person during the radio program, and subsequent rules enacted to address such challenges had been disputed. The Court could actually assumed such great injustice on cacophony of views and opinions in the breakneck speed and massive frequencies of broadcasting, and eventually snuffed out an embellished argument with the freedom of press--the kind of sensible balance on their licensed status (1969). In this balance, we can even imagine the right essentially reserved with the government to revoke the license itself. The applicants for the scarcity of frequencies are large that the operating broadcasters should be fortunate and privileged who is duly required to serve the public interest besides their freedom of business or expression. In the actions of FCC, Red Lion was not divested of license to broadcast, but grumbled with the minimal action to ensure the history long fairness rules on broadcasting.

\section{Thoughts on the Impact}

The Court viewed that the measure and regulation are welcomed and compatible with historic touchstone of fairness doctrine founded to deal with the new industrial sector of telecommunication technology. Several feels arise in reminiscence (i) proportionality principle are a tacit — but the kind of omnipotent pendulum to gauge the legality of administrative ruling - even the constitutionality of statute and regardless of comparative tradition (ii) concept of human rights are a crucial specimen-deeply embedded element of social justice even in the modern technological and rapidly changing market (iii) the court response can be diversified to cover a variety of challenges.

First, the proportionality principle had its express chapter in US when they deal with criminal punishment. The Eighth Amendment proscribed a cruel and unusual punishment, and also implicated on the principle in sentencing. As we see, the congressional act on sentencing guideline has been upheld as constitution. The proportionality principle is a leading principle in the civil administrative laws and considered an essential ingredient of rule of law ideals (Hinarejos, 2010). It is placed in the first of public law discourse that the disarray of theories and court rulings are intended to be foreclosed. The court opinion in Red Lion underlay this tone and rhetoric that the FCC has been endorsed amply to act on the cause of social justice if the balance on harms and public interest would fall within the permissible latitude on that principle. Second, let me reiterate that the Court had led the thought process of policy makers for the consideration of spirit and intent of First Amendment drafters, by saying, "by the same token, as far as the First Amendment is concerned, those who are licensed stand no better than those to whom licensees are refused.... It is the right of the viewers and listeners, not the right of broadcasters, which is paramount...(Red Lion Broadcasting Co. v. Federal Communications Commission, 1969)." The ruling would impact on the future of FCC which agency is responsible for this characteristic market, for instance, the rapidly developed internet service provision. One point of notation is between "speculative and genuine" as the Court ruled, "the danger that licensees will eliminate coverage of controversial issues as a result of the personal attack and political editorial rules is, at best speculative, and, in any event, the FCC has authority to guard against this danger." In that concern, the contention to demand a due policy would be 
more divergent - not simply involved with the consumers - involved with the producers themselves, say, mid-size or even individual providers with the merger issue, as well as varying with the different classes of interest on technological indication. Third, the Court has expressed the intent on constant monitoring about the constitutionality of action that reserved an extensive endorsement at one time controversy (Neubauer, Meinhold, 2009). This point has a typical way that embeds the "institutional primacy" than "primacy of principle" in comparative thought of two major legal traditions globally. As once illustrated, this has strengths and could be more legally certain in aspect and as commonly shared with the evolutionism. The conglomerate of case laws would be an asset and practical to deal with separate branches, which is likely more judicial than political. Chevron rule would be a facile avenue to allay the fear of political primacy and respect of collective willed branch. In this sense, the Court is a sacred forum for the minority and deprived for some cases, and for less afforded, but universal subjects such as listeners or viewers in this case, other than privileged or selected broadcasters. On the while, the impact on the agencies can be received more broadly with the life-time learning concept in which the branches of government constantly learn with the changing environment and new challenges. 


\section{Reference}

Hinarejos, A. (2010). Judicial Control in the European Union: Reforming Jurisdiction in the Intergovernmental Pillars, New York. NY: Oxford University Press.

Kim, K. (2014). The Relationship between the Law and Public Policy: Is it a Chi-Square or Normative Shape for the Policy Makers?

Social Sciences. Vol. 3, No. 4, 2014, pp. 137-143. doi: 10.11648/j.ss.20140304.15.

Kim, Kiyoung, On the Fundamentals of Law and Public Policy (April 13, 2015). Available at SSRN: http://ssrn.com/abstract=2593758 or http://dx.doi.org/10.2139/ssrn.2593758

Neubauer, D.W., Meinhold, S.S. (2009). Judicial Process: Law, Courts, and Politics in the United States, Cengage Learning.

Shapiro, M.M. (1988). Who Guards the Guardians: Judicial Control of Administration, Athens. GA: University of Georgia Press.

Chevron U.S.A., Inc. v. Natural Resources Defense Council, Inc., 467 U.S. 837 (1984).

National Cable \& Telecommunications Association et al. v. Brand X Internet Services et al., 545 U.S. 967 (2005).

Red Lion Broadcasting Co. v. Federal Communications Commission, 395 U.S. 367 (1969). 


\section{The Court, FCC and Internet Policy}

\section{Overview}

The internet is one of most influential invention which affects our civic lives. The mode of interaction is typical from the traditional telecommunication services, such as telephone, TV, or radio. The internet usually is connected to the PC for public use and now enhanced applications are used in the form of hand-carried Smart Phone. The invention of telephone had made a significant impact society-wide and one of important achievement to bring a new concept of industrialization (Crawford, 2014; Lachman, 2009). The radio and TV also transformed the society that the people now became exposed to a wide of social events or entertainment and the democracy had been consolidated. The internet in the current form of use would be a space of interchange and the kind of hybrid product combined of three natures in mode. It has a screen to deliver the view and pictures like TV, but the sounds generally lack over the portals in few exceptions, such as reading service of on line journals and music providers of Y-tube and others. It may also merge the programs of TV to subject to the part of service providers, for example, ABC news in the portal. The scope of information communicated through the internet would be tremendous in content volume and such diverse in terms of sorts and traditional rubric of public awareness; on-line books and journals, electronic encyclopedias as notable of Wikipedia, on-line trade and businesses such as Amazon or Paypal, and portals of social media, such as Facebook, Academickeys, CareerCast. Although the nature of scientific technique may not rival an invention of electricity or basic telecommunication services, its impact on the society is fairly square and profound.

In terms of political viewpoint, the internet would bring the kind of many important transformations and international conflict (Owen, 2015; 2009). For example, the election mode may acknowledge the benefit of internet that on line votes may be made official in some context of polls. The concept of e-government has recently turned popular that now is being considered as necessary and indispensable or a specimen of democratic progress in underdeveloped countries. The cyber war had been reported occasionally as a new form of terrorism and indirectly demonstrates the significant impact of internet and its security.

In terms of civil or social lives, it is notorious that the current public had spent much of his or her time to interact with the internet mode of telecommunication (Nunziato, 2009). While the advent of film in early of this century and subsequent development into home use of TV would be an important turnpike to the wider scope of popular democracy, the internet could well follow to continue dismantling the traditional area of prestige and enclaves of ruling class. The freedom of expression would be more in strong impact with the kinds of open access trend over various sectors of society and the internet space has been an important forum of public debate, say, the source to gather information as well as the avenue of social or public interchange. The on-line education has grown to dispense the levels of academic degree in the universities, and one way of scholarly exchange through submission of journal articles and teleconference on the internet basis. Perhaps the contemporary citizens would spend more time through the internet or Smart-Phone activities than viewing TV, which is distinct from the decades ago.

In terms of ethic, law or regulatory concerns, the internet phenomenon requires policy makers to respond actively with the challenges, including but not limited to the 
invasion of privacy, new mode of crimes, new pattern of copyright or trade secret issues, new mode of businesses and corporate issue as well as new concept of property rights and public justice involving net neutrality (Kim, K., 2015). The context of evolution over the legal theory or regulatory framework may differ across the countries since the social compassion or national culture would not be same depending on many factors or traits. That is true although the internet represents the ubiquitous commonality through universal exposure oftentimes or the telecommunication technology is on the same root basis. For example, Koreans view that the owners of telecommunication service shall be defined as "common carrier" which should be neutral and basic other than the commercial entities so as not to exploit the internet use to their prurient interest. In Korea, there would be three major service providers in terms of telecommunication infrastructure, i.e., SK, LG and KT. On the other hand, the federal telecommunication act in the US would define such major providers as information service other than common carrier, which shall profit depending on their competitiveness within the market and according to the market principle (Lee, 2015). For example, the businesses categorized as information service can impose the fare of internet use which will be based on the time of use.

\section{NCTA v. Brand X}

The Brand $X$ is one of important Supreme Court decisions on the net neutrality principle in US (National Cable and Telecommunication Association v. Brand X Internet Service, 2005). As briefed on the contemporary mode of livelihood for the citizenry, the internet or cyber space has a scale of influences that had been transformative, perhaps at exhilarating and fantasy on the science and business community, and steadily into the consumers. We have enjoyed a radio, television, and now the kind of monstrous internet device as our book shelves, e-repository of articles, government documents, and video games, social e-media and e-newspaper, wireless mobile phone service, music of y-tube, through the personal webpage. Besides the medical and space science, the sectors not only received a stellar attention of public, but also even amount to require a paradigm change over the social science and humanity. The context had been sketched with my limited exposure of daily lives above to have a due curtail here. Naturally, the internet is now challenged from the policy considerations as principled in terms of net neutrality (Tim, 2003; Yoo, 2005). The net neutrality, as a matter of definition, requires [that] the internet service providers and governments should treat all data on the Internet equally, not discriminating or charging differently by user, content, site, platform, application, type of attached equipment, or mode of communication. Generally, the policy issues are to be narrowed with the government, but not the case in this definition. This lends a soft prism of framework, but implies the attribute of issue impressed with the high impact and spread through the public than any other businesses. The policy position or determination of specific controversy permeates the public domain in any pounding consequence, but involves a difficult or callous technical aspect of policy options as a challenge.

This backdrop might create a feel and destination of majority court in Brand X, so that it ultimately deferred to the decision of FCC on the Chevron rule (NCTA v. Brand X, 2005). As a numbered webpage of Wikipedia implies, the net neutrality would be any contentious issue in the US partly because the economy is most advanced and also because a cult over the global community had been shared. Nevertheless, the issue entails a public aspect that we could see a general discussion on the principle of net neutrality as a matter of livelihood and public justice. The arguments to propose the net neutrality normally includes the consumer advocates, human rights organizations, online companies and some technology 
companies. The net neutrality opposing group would arise in diverse context, principally the big companies, notable technologists, President Obama, several civil right groups (NYT Editorial Board, 2014). As seen in above definition, the issue could be truncated into the some alignment of providers and governments against the consumers. That is vastly true, but the issues--as hinted from arguments -- more precisely speaking, would involve diversified policy interest groups. The issues of small business and civil views of complicated challenge can have their own cause. Eric, a Google CEO, could be proper with this challenging environment, whose view is modest and eclectic "while Google views that similar data types should not be discriminated against, it is okay to across data types..." The statement of former FCC chief of policy development, R. Pepper shows a basic tenet of both arguments "The supporters of net neutrality regulation believe that more rules are necessary...without greater regulation, service providers might parcel out bandwidth or services, creating a bifurcated world in which the wealthy enjoy first class internet access, while everyone else is left with slow connections and degraded content." (Nate, 2009).

The consequence of majority opinion has left an interpretation of FCA and classification of internet service providers within the discretion of FCC. It specifically confirmed that the Chevron rule must be applied if the provisions are vague even when the precedent of same court (in this case, ninth division of federal circuit court) guide as a binding power (NCTA v. Brand X, 2005; Chevron U.S.A., Inc. v. Natural Resources Defense Council, Inc.,1984). Since there is no precedent of Supreme Court on the subject matter, the Ninth Circuit would search any same or co-equal rank of court decision and apply it, which however was rejected on the ground that the stare decisis effect could be bought only when the agency interpretation is "unambiguous to conclusively match up to create a certain rule with the statutory provision" in terms of Chevron. Given if the statutory provision is vague as an original text, the FCC could read it in other way later on different situation or newly emerging challenges that is the rule of Supreme Court now at hand. This has a merit from viewpoints: (i) the Congress and FCC are ensured of an equal rank of brother branch with the Supreme Court (ii) the Executive of US Constitution is unitary in line authority and hierarchy that the FCC is also equal with the head of Executive in terms of decision making hierarchy exceeding the federal appellate courts; (iii) the Supreme Court suggests that more adequate policy making body for the interpretation and enforcement of statute would be FCC than lower courts, which retains and exercises expertise and wealth of traditions or expertise on the concerned regulatory field. This ruling, however, provokes the kind of general questions, if the FCC is such robust to consider all the facets of factors or variants beyond the law and national economy. The lobbying groups perhaps would be a larger corporation on the field and the economic impact would be their prime concern in normal countenance. Nevertheless, my reiteration is relevant here that the net policy brings an omnipresent effect on the current mode of livelihood as well as social beings, or even frames. Then the court would be more adequate forum to argue on the spectrum of consequences brought by the net policy. So it is interesting that the Ninth Circuit also relied on the legal rules that the stare decisis is determinative to dispose the case (Brand X Internet Service. v. FCC, 2003).

That is an essential of common law system that the common law judges could not betray ultimately. Unfortunately, however, the rapid progress on the related science and demand of business world would create to earn a damage that the proper policies will not follow back succinctly and in timely fashion. We may remain, however, as a commoner or kind of nobility like the judges, to be shared with the enjoyment and pleasure of internet development. As I have argued elsewhere, the certainty, stability and predictability is an 
essence of noble class that the judges generally pursue to serve the community in their stewardship, but could possibly be biased with the marginal market of competition and complicated tech-business.

The kind of legal ideals would be intrigued with the formalism and structural certainty as Justice Scalia argued in his dissenting opinion (NCTA v. Brand X, 2005). I agree that the Supreme Court might not be scrupulous with its reasoning and rhetoric. First, the Supreme Court had not needed to mention on the stare decisis effect of Ninth Circuit. Since the Supreme Court is legitimate to overrule the lower court's ruling, only two ways could stand if it denies the entitlement of Chevron deference and advance to specifically illuminate the right or permissible interpretation of provisions or if the Chevron rule duly governs the controversy at hand. If beyond this simplified response as the Supreme Court here, it would create an unnecessary excess of rules on the stare decisis generally or on the Chevron rule narrowly. This could lead to new agency reversal rule, as he coined, which only effects to increase a burden of defense on the Court in the future cases. Second, his argument on the possible abuse of agency power to interpret statute would implies his worry that could derelict the finality of judiciary or general higher role of judicial supervision of federal agencies (2005). Structurally, then, would the Court differ between the judicial control of agencies action and balance of constitutional ranks of branches, especially given the lower courts being subjected to the legislative enactment for their organizing and status. I seem to consider the court strength as a public forum on multifaceted policy consideration, but the national agenda of this kind would highly be challenging to create the paradigm of market that the FCC would likely be more competent to enjoy the Chevron deference. Since the dissenting opinion had not included a specific mention on the merit of subject matter, it is uncertain how it impacts the net policy in the US. If the lower court judgment needs not to be sustained as a rule-- suggested that it should be overturned and practically same with the majority opinion - the dissenting opinion seems to part with the net neutrality that the providers would be regulated at more extent.

\section{Figure 1 : Differences Between Korea and US}

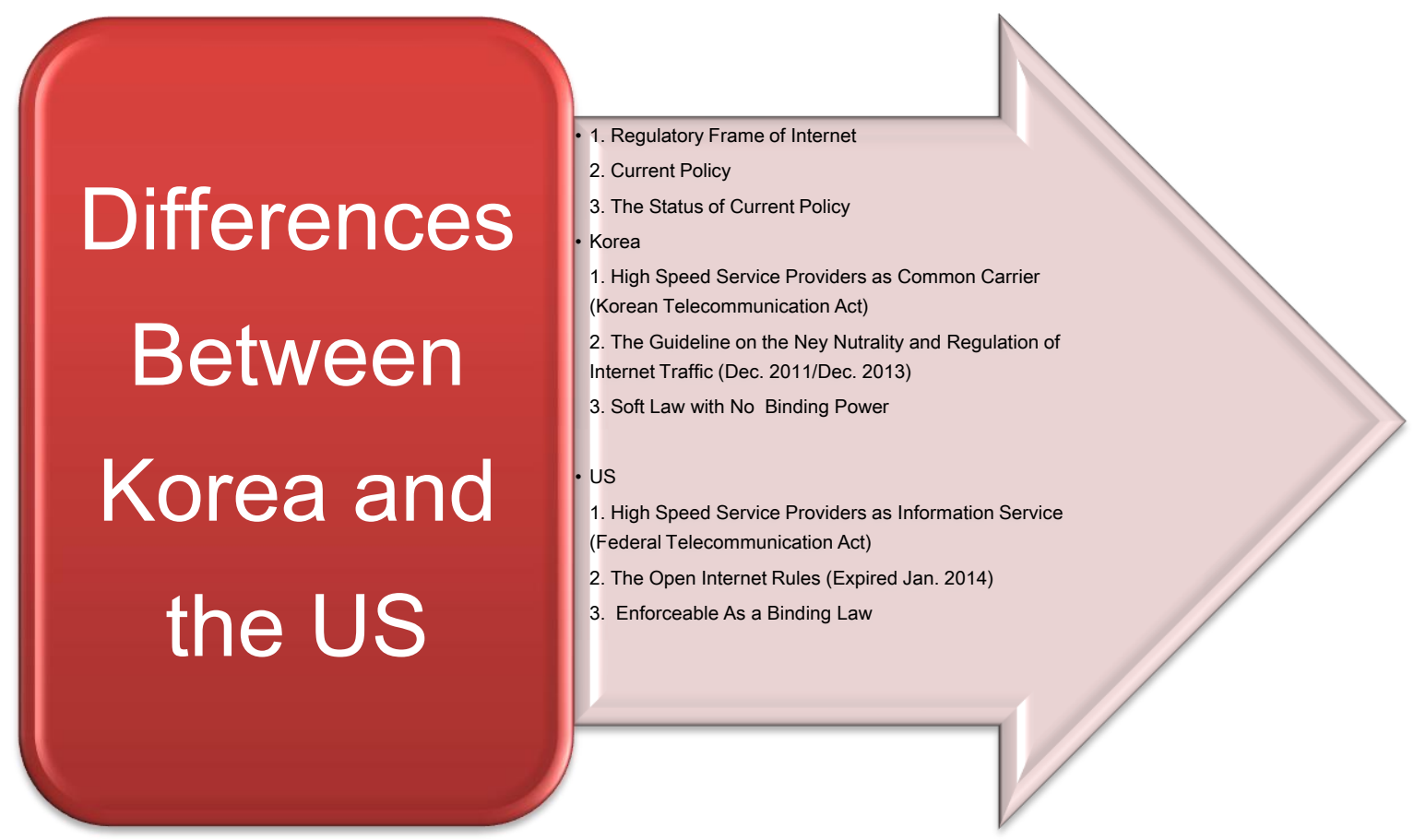


In this case, the Supreme Court was called upon to determine on the statutory meaning of "telecommunications service" and "information service" defined in the 1996 congressional act (Telecommunication Act of 1996). The FCC has exercised a subject matter jurisdiction, which concluded that cable companies to sell the broadband internet service does not fall within the classification of telecommunication service under the act, and "hence are exempt from the mandatory common carrier regulation under the Title II (Berkman, 2014). The issue in this case is whether the determination of FCC could survive as a lawful construction of FCC under the rule of Chevron. The Broadband in this case provides a high speed connection service distinct from the traditional means "dialing up" to local phone facilities.

Figure 2 : Classification of FCA
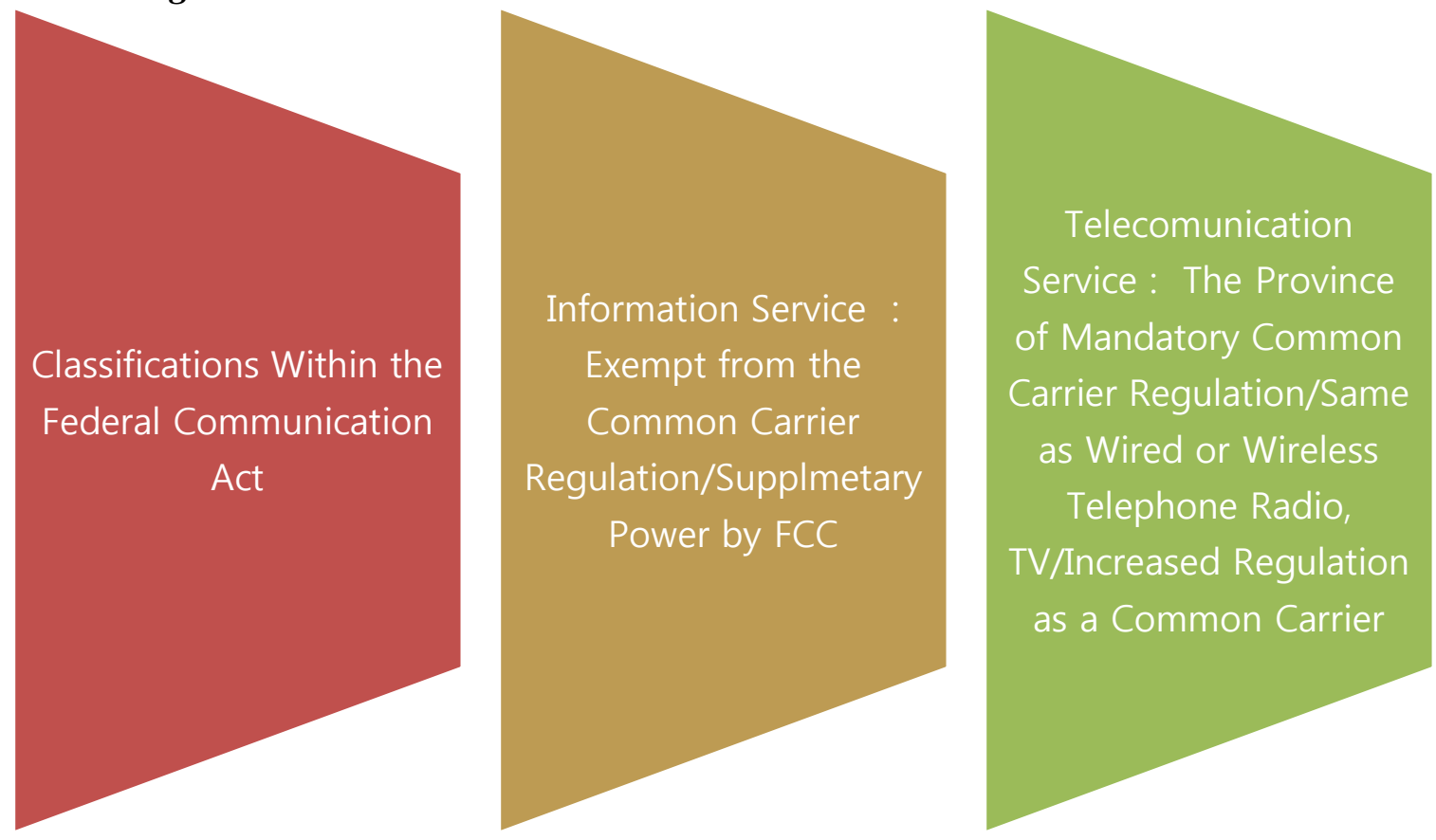

The case is the first Supreme Court case that deals with the FCC action on the net regulation, and had centered on the crucial stage of technology change from dial-up to high speed broadband or cable network. The case is significant to affirm the wider discretion of FCC in the battle over network neutrality in the United States. As seen, the Court overruled the United States Court of Appeals that Chevron rule must be applied other than stare decisis principle unless the Court found the statute unambiguous under Chevron. The judgment, by upholding the FCC's determination, brought a limited scope of telecommunication service excluding such competing internet service providers (ISPs) like Brand X. It was remanded for further review of Ninth Circuit (Brand X Internet Service v. FCC, 2006). According to the Supreme Court ruling, a scope of ISPs became to be denied access to the cable and phone wires to provide home users with competing internet service, implicating an impact of internet market, for example, more competition-based information service, new class and profit paradigm of telecommunication service, ensuing merger and acquisition and so. The net policy of United States has a history in time line with several important stages (WorldCom, Inc. v. FCC., 2001; Verizon Communications Inc. v. FCC, 2002). 
In 2004, FCC announced a set of non-discrimination principles, and urged network freedom without regulation. The four freedoms specified by Powell, then Chairman of FCC included (i) Freedom to access content (ii) Freedom to run applications (iii) Freedom to attach devices (iv) Freedom to obtain service plan information. The network freedom and neutrality principle was willed as shown in early 2005 Madison River Case, and did not fine Madison River Communications (Powell, 2004). It did not confirm that FCC would remain entirely free of regulation since the dispute has been disposed in settlement than formal finding. Immediately over years, the new technology change has necessitated a new policy impacting on the competitive local exchange carriers (CLEC), dial-up connection and digital subscribe line (DSL). In 2004, the Court of Appeals decided on the unbundled network elements (UNEs) for incumbent local exchange carriers and competitive local exchange carriers, and voided the USTA ruling on the FCC's authority to enforce rules requiring telephone operators to unbundle certain parts of their networks at regulated prices (U.S. Telecom Assn. v. FCC., 2002). The decision obviously chilled the FCC's net neutrality and network freedom principle, and the consequence had been a significant injury and collapse of CLEC (Brauer-Riekie, 2009). We generally see that broadband services have two important sorts, cable service and DSL, in terms of public regulation and according to the net technology. The former has historically been free of regulation with the classification of information service while the DSL was subject to the extent of regulation as a telecommunications service. In 2005, the FCC announced important new principles conditioning the Network Freedom and neutrality on the concept and due requirement of law and public regulation. It consisted of four net neutrality principles as of voluntary nature (FCC, 2005). For example, it included that consumers are entitled to access the "lawful" Internet content of their choice, to run applications and services of their choice, subject to the needs of "law enforcement." It also emphasized the market competition to the interest of consumers (FCC, 2006). Shortly after the Supreme Court decision was rendered, representatives from several major U.S. corporations and the federal government publicly addressed the four important philosophies of U.S. Internet services in 2006-- the nature of free market forces, the public interest, the physical and software infrastructure of the Internet, and new high-bandwidth technologies (Brauer-Riekie, 2009).

\section{Subsequent Policy Arguments within the Three Branches}

Given the Chevron standing, the subsequent policy arguments have been led by FCC, President, business enterprises, consumer or civil cause organization, Congress and part of judiciaries not directly involved the issue of classification. If the majority and dissenting opinions are practically same in effect, we can view such serious aftermath involving the advocacy or criticism on net neutrality as a due consequence that the future Court has to be more attentive. If the dissenting opinion is viewed to support more than increased role of Court on net policy, the consequence may be a basis to critique the majority court.

Nevertheless, the FCC actions after the 2005 decision are considered to generally be strong as a regulator of market to the various interest groups.

Over the next few years, FCC tried on several rulings to elucidate what the net policy was meant practically. In August 2008, the FCC made its first Internet network management decision upholding a complaint against Comcast, which alleged to ascertain as Martin, the FCC chairman, mentioned, "the order was meant to set a precedent, that Internet providers and all communications companies could not prevent customers from using their networks the way they see fit, unless there is a good reason" (Hansell, 2008)). However, the FCC's 
2008 cease-and-desist order against Comcast was denied by the U.S. Court of Appeals on the ground that the FCC has no powers to regulate any Internet provider's network, or the management of its practices. It found that the FCC lacked the authority under Title One of the Communications Act of 1934, to force ISPs to keep their networks open, while employing reasonable network management practices, to all forms of legal content (Cheng, 2009; Communications Act, 1934; McCullaugh, 2010). The case seems to underscore the rigorous standard of review on the FCC's power although the Court had deferred on the Chevron rule within the policy area of classification and formulation of market structure. The FCC also employed a soft nature of policy such as spectrum auction, and President and major companies, such as Google, had interplayed to develop the net market. In 2008, the FCC auctioned off the $700 \mathrm{MHz}$ block of wireless spectrum in anticipation of the DTV transition, and Google promised responded with four conditions which were broadly similar to the FCC's Internet Policy Statement. In 2009, FCC reaffirmed its basic policy through a series of proposals in public forum that would prevent telecommunications, cable and wireless companies from blocking certain information on the Internet, for example, Skype applications and required the transparency principle that ISPs disclose all their policies to customers. It also was principled that the net neutrality shall apply in the same fashion both to wireless and wireline services (Ruane, 2009). Importantly in 2010, FCC has issued a mandatory nature of FCC Open Internet Order 2010 to align its policy and experience with the needs of market and public. It basically banned cable television and telephone service providers from preventing access to competitors or certain web sites such as Netflix (Eveleth, 2014). A set of 6 net "neutrality principles" were announced by FCC in 2010, which provides concerning (i) transparency (ii) mo blocking (iii) level playing field (iv) network management (v) mobile (vi) vigilance. The network freedom and neutrality had been substantiated with the increasing profile of internet market (Kang, 2010). For example, the level playing field is guaranteed of consumers and innovators, which requires a ban on unreasonable content discrimination. On the other, the so-called "pay for priority" arrangements involving fast lanes for some companies but not others was allowed--hence did not keep ISPs from charging more for faster access. The measure can be toned with the majority of Court position that allowed the wide latitude of regulation, but was contended in Verizon (2014). The Court vacated portions of the FCC Open Internet Order 2010, and found that it relinquished its right to regulate the broadband providers -- classified under the Title of the Communication Act of 1934 as "information service" as seen in 2005 decision-- since the authority to impose the order should be limited to common carriers. The OIO 2010 was critiqued by the net neutrality advocates over price competition, and the case is considered of shrinking impact by limiting the authority of FCC to impose it on the scope of common carriers business. As the service providers were not identified as "common carriers," the FCC authority had narrowed. However, the court agreed that FCC can regulate broadband and may craft more specific rules that stop short of identifying service providers as common carriers (2014).

The subsequent development upon Brand $\mathrm{X}$ has implications to confirm our assumption that (i) the internet market has been evolutionary and volatile in terms of public policy and regulation (ii) sensitively intertwined with policy environment with their wide influence on various aspect of human activities and existence (iii) the laws and policies would correspondingly come newly emerging and modifying. Hence, the majority opinion can have a merit by respecting the determination of FCC on the Chevron rule, which allowed a wide latitude of policy measure on part of FCC and practically brought the effect, "wait and see," on behalf of its supervisory role. The dissenting opinion, by calling upon the clarity of majority opinion and against the arbitrary ruling of FCC - had hinted on the importance of 
structural balance among the involved players, which hopefully could prevent a frivolous measure of FCC inconsistent with the previous position. The public voice on the issue may diverge. For example, as a response to the DC Circuit Court's decision, a dispute developed as to whether net neutrality could be guaranteed under existing law, or if reclassification of ISPs was needed to ensure net neutrality $(\mathrm{Hu}, 2014)$. Wheeler and President Obama would have a separate view that President Obama, supported reclassifying ISPs as common carriers under Title II of the Communications Act of 1934, while the FCC argued for the authority under Section 706 of the Telecommunications Act of 1996 to regulate ISPs. Over series of action over the year of 2014, on November 10, President Obama recommended the FCC reclassify broadband Internet service as a telecommunications service in order to preserve net neutrality. The development tended to get embroiled with the kind of interbranch power game and challenges with the supervision and collaboration given the difficulties and complicacies as a public issue. Actually on February 19, 2014, the FCC announced plans to formulate new rules to enforce net neutrality while complying with the court rulings (Nagesh, 2014). Interestingly, on January 16, 2015, Republicans presented legislation, in the form of a U. S. Congress HR discussion draft bill, that makes concessions to net neutrality but prohibits the FCC from accomplishing the goal or enacting any further regulation affecting ISPs. Along the progress, it echoes that the constitution is any final touchstone to integrate on various arguments and policy disagreement as the FCC chairman, Tom Wheeler, commented, "This is no more a plan to regulate the Internet than the First Amendment is a plan to regulate free speech. They both stand for the same concept" (Lohr, 2015; Gross, 2015).

\section{Consequences and Influence on the Public Policy: Partly with Korea}

The Court opinion would incur a remedial measure of FCC on vast of net policies involving the neutrality and commercial freedom because the Court had ascertained the principle of deference on Chevron rule. The power and discretion turned to be more political than normative, and the latitude of FCC would deserve a public interest. With respect to less of judicial supervision, the FCC had adopted new policy initiative by 3 to 2 vote in 2014, in which the content businesses will be provided with a higher speed of telecommunication service (M.H, 2014). This would well create a condition of market on more competitive basis that the market principle and the social justice or public utility and goodness would be honed in regulating the internet service (Kim, 2015). The market, however, will seem to be regulated on the fee basis that more paid information service will be legally guaranteed with a quality service. The telecommunication service, defined as common carrier and subject to rigorous regulation for public goodness, would welcome the policy as a new revenue source. On the while, the information service, especially new entrants into the market, would be divested of privileges and advantages as a public enterprise and with a neutral fare notwithstanding their contribution as common carrier. This would be suited to the principle of liberal market on one hand, not to be freed entirely from countervailing argument on public value as well as paradigm of right to know and freedom of expression. For example, the new policy could incense the adherents of fairness school, who perceives separating the big hands from content creation and dissemination would be a threshold--essentially interwoven with the free flow of ideas and fair opportunity on public issues (Wyatt, 2014). In other words, the contents and application, as said of higher structure of internet, shall be severed from the influence of lower structure of internet, mostly dominant in finance and powerful or backed with the political power. It is prerequisite to ensure the sanctity of internet space, the kind of public forum on various events, stories and issues or agendas, that the telecommunication service will be impartial and dispassionate as well as regulated so as not to be arbitrary or 
interested to possibly penalize the content businesses. For example, SKT may infringe with the right of consumers if to discriminate the Korean Naver from Google by assigning a high speed of telecommunication service (Lee, 2015).

However, it is very likely that the things have changed since the internet traffic increased tremendously and even the investment in the internet of things would be no less than frequent. As the legal environment had sharply shifted its landscape, it is natural to follow up with the new norms or reforms of policy and public regulations. The new policy initiative does not appear to bring instantly the pricing policy of internet providers, but it posed the challenge to reconsider the operation or meritocracy and public service of outdated principles or obsolete policy packages. While the Court ruling had affected notably the FCC and ensuing state or local policies incidental to a deferential rule of judiciary, the impact could wield an influence within the national market since the FTA between two countries would impose many treaty obligations in terms of non-discrimination. Furthermore, the legal system shared extensively to import the US mode of internet regulation. The Department of Creative Economy and Science, inter alia, invoked the regulations of FCC in the current frame of public policy on the telecommunication and information services. The KCC (Korean Communication Commission) also would practice largely as same with FCC. The Article 15.7 in FTA also contains same of regulatory measure to the current policy of FTA, which covers the rules on the public access and use of internet for electronic trade (Kim, 2009). 2015). The factors would bring some direct consequence on the internet services of South Korea. For instance, the telecommunication services, in tandem, had released a new LTE option of service fee, but restricted the size of data contents with mobile phone (mVoIP), such as Kakaotoc. Years ago, the telecommunication service had disputed with Smart TV of Sam Sung electronic (2009).

Nevertheless two countries would differ from several points, but very markedly. As mentioned, Korean policy emphasized more than the US the principle of neutrality by granting the status of high speed telecommunication service as common carrier (Yoon, 2010). The policy has long been pursued that unreasonable blocking or discrimination would be prevented effectively. The foundational policy created in 2002 Bush administration would assume that most of telecommunication services would be classed as common carrier in terms of public regulation. This is, of course, because the history of industrial development led to the liberal initiative on market paradigm in US, while the state-led industrialization in Korea generally monopolize the key sectors of infrastructure under the control of national government. The 2005 Court ruling in US would be construed to ascertain the kind of national policies so that subsequent development had been mounting as briefed although those had never been appealed to the Supreme Court (Editorial Board, 2015). The differing extent of public concern or repercussion from the changing environment of internet would stem from the backdrop of both countries. Korea would generally be less volatile on the regulatory issues while FCC and other public agencies, including the lower courts, in US had been disposed in extensive engagements to seek a better policy. Particularly because the DFCS of Korean government had announced a supplement of policy items on net neutrality in Dec. 2013, we would be unable to receive additional adjustments in the near future. Once again, we are reminded that the important difference underlies the regulatory frame of two countries. While Korea relies on the guideline lacking a binding power to enforce, the FCC is empowered to sanction and provides a remedial measure ensuring the compliance of regulates. Some analyst on this issue commented on the ambiguities and opaqueness of prospect, "The turns of policy would be positive generally, but we would never be 
comprehensible at this point of time if the telecommunication services had been petered out actually and Korean particulars in policy variants would allow it capricious" (2010)

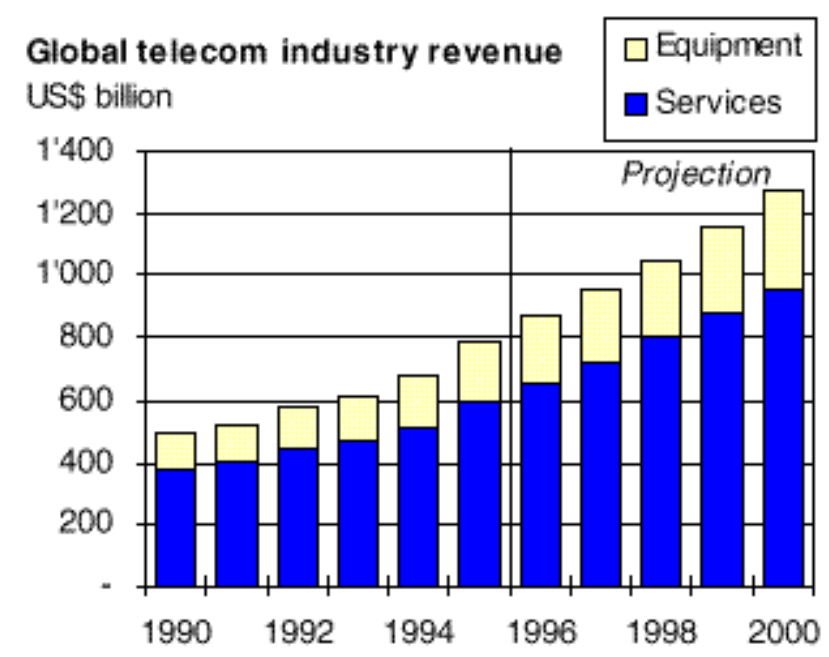

The statistics in 2013 show no disparity among the two classes of business in terms of growth in the security market, but the picture changes steadily entering the second period of term. We may infer three possible reasons (i) FCC announcement of new policy initiative (ii) globally low interest rates and attraction of dividend as well as defensive strategies of investors (iii) investor's expectation for a large scale merger and acquisition. The trend in businesses is realistic indeed that AT\&T planned to merge DirectTV, and Comcast will merge Time Warner cable. Sprint, third in the mobile telecommunication industries, had petitioned for T-mobile. In Europe, Orange had filed for a merger with Bouygues. Although the merger would develop a provision of internet service, one sensitive issue of laws could embroil with the anti-trust laws that calls upon due monitoring or supervision of governmental body (Kim, 2009). Netplix, one competitor against the merger, sent a letter of disagreement to its shareholders specifying that an acquisition of Time Warner cable by Comcast will discourage a competition and increase a subscription and service fee (Ruane, 2013). According to the Wall Street Journal, the supervision authority will not repudiate the kind of trends, and expects the growth of market on the notion of fair competition to the welfare of consumers.

\section{Several Policies of US as Influenced and Comparatively}

The net neutrality is considered to have a growing significance in terms of public regulation that the wide impact of ICT (information and communication technology) has brought an internet-based business. This accelerated rate of internet access inevitably drives it to be a crucial policy issue in response with the welfare of consumers, the industrial growth of ICT-related business, as well as advancement of industrial structure toward the kind of creative economy (Staff, 2015). The controversy on net neutrality, hence, needs to be focused on two central objectives of public policy, say, a due protection of consumer interests and sustainable development of internet ecology, which could be made feasible with an openness and ecological soundness within the internet community and sustained enhancement of networks. The most prominent challenges in this progress would arise in four important aspects; (i) the competition became intensified among the players within an increasing kind of ICT markets due to the fusion of network and information technology as developed by AllIP or digitalization (ii) the telecommunication services increasingly tend to impose an 
additional fee for the content providers as stimulated by declined growth or stalemate of small market (iii) the new trend of ICT markets generally necessitates the ISP's right and duty s a gatekeeper of Internet (iv) the enhancement of network quality has to be ensured with the increasing participation and shared sacrifice of various players beyond the telecommunication service, which generates a revenue from the internet business. It needs to be noted that the new internet policy is required to recognize the importance of content producers, which is thought an important class of players to consist of two or three dimensions in this area of public policy (Stiegler, 2012). The horizontal frame of approach perhaps would be a new perspective in addressing the challenges, which alters the vertical one. It is viewed within the horizontal frame that we can identify two or three dimensions of players, which vibrate and boost the ICT economy. In the former, the network providers and content producers are the policy subjects, which can leverage in same quality and domain of interest. In the latter, we can identify other independent dimension what we can see as platform. The delicacies between two classifications could influence the shaping of internet policy--especially involved with fair terms of competition and sensibility of economic justice among players (NCTA v. Brand X, 2005).

As viewed, the net neutrality actually resulted in equal treatment of all data packets and no priority delivery should be conceivable among the players and as indifferent with contents and the terminal application subscribed to the network. The principle was developed in early of new millennium by Tim Wu, and backlash followed by disagreement from scholars, notably and led by C. Yoo $(2003 ; 2005)$. These scholars use network diversity in highlighting the importance of issue and discriminatory effect of network or telecommunication service. A typical practice to violate the net neutrality would include P2P traffic blocking, restriction on the transmission speed, blocking of mVoIP in 3G net (Kim, 2015). In the extreme, the business practice on tiered internet traded in the commercial purpose may be regarded as to impair the net neutrality. Currently at the center of debate underlies the imposing shift of internet markets, in which the policy makers have to elaborate to resolve the conflict of interest between ISP and 3PP ( $3^{\text {rd }}$ party player). These players generally pertain to the first classification above, and need to be used expansively to encompass all the interested parties within the internet community. Hence, we could cover the content provider, application provider and device provider as 3PP. The imminent needs to upgrade the regulations and reform a stereotype of traditional policy is not mere hypothetical, but demanded to address the challenges of growing competition of service providers, financial burden to increase network investment meeting the traffic increase as well as the basic stalemate of telecommunication service and limited available capacities (2015). At the inception of ICT, both players reinforced each other to grow for the current status. Given the complication and growth of markets, the cause to block and discriminate ISP has increased that ISP pursued to legalize the right to manage the traffic--on reasonable commercial order-while 3PP adheres with the neutrality principle and current regulatory regime. ISP basically yields a profit from both of users and 3PP, which currently has transformed with most of profit being generated from users. The new commercial order, for example, in Korea, is being discussed to portion the fees of 3PP with the burden of traffic. In the concern, two policy issues arise to govern mVOIP and Smart TV. In Korea, SKT and KT maintains a closed system in which only fee based subscribers could be allowed to use mVOIP, and perhaps same with LGU+ being implied of fee base. This service is provided by MyPeople, Nateon Toc, Skipe, such 3PP free from payment of the net use for the telecommunication. Since the subscribers can use the service free from charge, the spread of mVOIP would eclipse the revenue base on voice sales against other players. They argue on free ride that $3 \mathrm{PP}$ would be 
unconscionably profiteering, which is countered by users and 3PP. They urge that it is their right to transmit the data purchased for the mVoIP (2015; Kim, 2009).

The US and Netherland had met these challenges with the reform of acts and regulation which banned the blocking of mVoIP by mobile telecommunications, but the international practices seem not uniform. Korean practice is imperfect that a considerable number of mobile telecommunications had compromised to preserve a part of their profit source and to the interest of public. In UK, Vodafone designed the service to allow the subscribers over 41 pounds monthly, and 15 additional user fee is charged otherwise. TMobile, a German corporation sets the minimum at 49.95 Euros for use, and additional 9.95 Euros has to be paid monthly for other category of users (2015). This business design is same at France, 49 Euros and 15 Euros respectively. One note may be given that the consumer right to opportunities in US seems not satisfactory although the principle is to mandate a ban of mVoIP blocking. That is because the consumers had to pay the high rate of data use fees at the incident of subscription. Verison requires 69.99 subscription fee and AT\& T 54.99 monthly subscription (2015). In Korea, the controversy has been brought as a civil action by 16 users of $\mathrm{mVoIP}$ and in consolidation with the civil activist associations in Oct. 2013. They claimed in the suit that the business practice of KT and SKT violates the art. 56 of Fair Trade Act, which interferes with the consumer right to opportunities and restrictions of competing service provision. The article provides a basis of tort damages in case where the businesses and enterprises violate the Act. The plaintiffs invoked two counts of violation, which specifies the abuse of bargaining privilege and prohibition of undue disadvantage. The Mobile telecommunications, of course, would raise contrary viewpoints. For example, it can be asserted that the current business practices a free ride without payment of due compensation for use of net, and they may argue on low subscription fee of users, disruption of their businesses from regulation, burden to the increasing investment needs, as well as consequential detriment to overall welfare of internet community (Yoon, 2010).

\section{Future Public Policies and Uniform Regulation of Korea}

The consequence of Court ruling ineluctably will lead to the enhanced policy making role on the part of FCC. Several points of legal response can be surveyed, and largely from the comparative view of Korean law on internet regulation. That would not be merely shenanigan, but can provide an example for the federal or state government since the federalism in the US context now resulted in a short of public response other than traditional civil law frame on promotion, damages and criminalization of internet-related crimes. As per the public policy, the Act prescribes several elements so as not to be omitted in creating and implementing policies; (i) advancement of net technology and its dissemination (ii) standardization of internet (iii) promotion of content development and use of internet (iv) promotion of common interest in use of internet information (v) protection of personal information and development of technology for that purpose (vi) security and reliability of internet (vii) protection of juveniles and youths. The scope of concern now principled in the Act can be partly derived from the statutes and acts, but general frame seems to be meaningful with assigning a principal duty within the relevant department or bureau (AITSPPP, 2015; Yoon, 2010).

For example, the Ministry of Future and Creative Science (MFCS) in Korea is responsible for the research and development, cooperation for and transfer of technology and technology training, which can be seen as distinct in terms of the developmental paradigm of 
state engagement on this rising sector of national attention. As the neo-protectionism guided, the developed nations, such as US and western countries, also need to keep emulative and on partnership spirit with underdeveloped peers. The research institutions would be funded completely or partially to compensate for the cost of development program, which is internationally permitted as WTO laws exempts from the subsidies category. I can illustrate some of duties according to the elements. First, the MFCS shall be a principal officer, who comprehensively administers on the management of technology and facilities related with the internet (2015). The minister can request pertinent agencies and national or public research institutions for the materials and data relating with the technological information. Unless contrary circumstances are present, the agencies and institutions shall respect the request. Second, the minister shall enforce the public programs and projects to disseminate the technological information, which facilitates the immediate and convenient use of it. The standardization of internet is commissioned with the minister, in which he publishes the standard of internet and advises the manufacturers and industries of the use of standard mark (2015). Third, the recognition and endorsement can supplant the standardization requirement that the manufacturers and businesses can utilize professional rating agencies appointed by the ministry (2015). Without such recognition and endorsement, they are prohibited from the standard marking or similar impression misleading the consumers. Fourth, the government can provide the financial and technical support for the producers of internet content, which purports to increase national competitiveness and public goodness (2015). The government also can provide the financial and technical support for the national, local agencies and public organizations which developed or operated the applied technology of internet use for efficiency, automation and upgrading of administrative task. The support program can be extended to the private sector, and the government has to breed the technicians and professionals to that end, which includes the expansion of internet education and creation or support of educational institutions, and so.

In the standpoint of fair internet access, it seems encouraging that the government has a statutory duty to remove the disparity of internet use and to promote it notwithstanding the residence, sex, and age. The quality control of internet service and increase of common interest for using the internet information through the build-up of supportive system had been prescribed as a ministerial obligation. These provisions principled to mandate the engagement of agencies and ministers had a bearing with the responsible administration and public system of recruitment on open application and contest for the cadre of public offices (2015; Yoon, 2010) .

The issue of net neutrality involves the protection of personal information and prevention of intrusion on privacy or defamation. The issues traditionally had been viewed with the frame of tort damages or civil action, which could curtail a due regulation with public law paradigm. Given it to be unregulated with special acts or decree, the Court should be a principal agency that may occasion a judicial invention for adequate treatment of violation and impairment into privacy or personal honor in the internet space (Kim, K., 2014; Yoon, 2010). The public frame with fines and light imprisonment based on the special act can be more productive, at least, in terms of public policy. The Court rationale with the traditional civil damages is to define both ways as separate and compatible, so that the violators have to fine and also must responsible for the tort claims in the civil proceedings. The internet mode of civil lives are disposed in distinct fashion that the European Court of Justice had recognized the right to be forgotten -- the consequence of a specific action in the past contravenes this nature of bestowed right (Directive 95/46/EC, 1995). In 2010, a Spanish 
citizen lodged a complaint against a Spanish newspaper with the national Data protection Agency and against Google Spain and Google Inc. He was disgruntled with the continued visibility to the auction notice of his home on Goggle's search although the matter was completely settled years ago. He filed a complaint with the Court requesting to remove or alter the pages in question and to remove the personal data that it could no longer appeared in the search results. In its ruling, the EU Court found on three accounts of controversy (i) on the territoriality of EU rules (ii) on the applicability of EU data protection rules to a search engine (iii) on the right to be forgotten. On the first account, the court viewed positively to encompass a large and cyber concept of territory- relating to the legal controversy on cyber space. This ruling, therefore, is considered the important judicial invention that legitimatized the applicability of EU rules to Google as illuminated on the second count of issue. The right to be forgotten can be ascertained with the individuals, but under certain conditions-where the information is inaccurate, inadequate, and irrelevant for the purpose of data processing (1995). In allowing the legal remedies, the court urged a case by case assessment -- type of information in question, its sensitivity for the individual's private life and the public interest in having access to that information-- and balancing against with other fundamental rights since the right is not absolute. The Google's right to free enterprise, freedom of expression and media had been argued to claim a due consideration, but eventually was not accepted by the Court. On the right to be forgotten, EU had enacted the 1995 Data Protection Directive, in which the right was principled as underpinned over articles, especially in the Article 12 titled the data subject's right of access to data (1995). The need of Directive is considered necessary and proper; (i) it needs to be updated and clarified for the digital age (ii) nonEuropean companies, when offering service to European consumers, must apply European rules (iii) effectively reversing the burden of proof to the interest of consumers (iv) effectively dealing with the obligation for a controller who has made the personal data public. The regulatory scheme had been imported to large extent within the Act of Korea, which provides the right to delete his or her personal information in 44.2, for instance. The concept of controller's obligation is to ensure a fair apportionment in terms of internet economy, sociology, public policy and normative challenge (AITSPPP, 2015).

The Act provides that the protection of personal information was spelled out in separate chapter (2) followed immediately by the next chapter (3), which deals with the right of internet users. In Article 27, the providers of telecommunication service are required to appoint the controller, who is responsible to protect the personal information of users and to process the problems or complaints of users on this issue (2015). The providers of telecommunication service shall disclose the policy of personal information when it deals with it and in any convenient manner that the users can readily access to it. The providers are obligated to immediately report-the specifics of personal information, the time of leakage, loss and theft, a possible remedy of users, responsive measure of providers, contact point of advice and consultation- to KCC (Korean Communication Commission) or Korean Internet Promotion Agency when it acknowledges the leakage, loss, and theft of personal information. Without a due justification, the providers of telecommunication service shall not delay its duty of reporting over more than 24 hours (2014).

\section{Insight and Prospect}

Given the pattern of our public lives in the e-communication age, the net neutrality involves a square aspect of communal interests and impact on the policy areas (Crawford, 2014). The role and responsibility of FCC had been challenged by the liberalist cause in the 
US and new enactment on the KCC around 2007 had been critiqued by scholars of concern and interest (Yoon, 2010). The content regulation would be debated by broadcasters and producers of cable programs since the national policy should be coherent and integral encompassing all the sorts of public issues. The federalism in US may delimit a Congressional jurisdiction unless it comes within the scope of federal power which little differs from the unitary scale of national regulation in Korea. The Court opinion, relying on Chevron rule, tends to generally create the feasible policy condition against the challenges that potentially thwarted a traditional notion or public value revered to constitute the principle of modern democracy besides the economic policy, as seen with the anti-trust issues and tendency of monopoly (NCTA v. Brand X, 2005). Given the disparity of industrialization history and incongruence depending on the particulars of nations, we may not generalize the consequence of adherence or deference on the net neutrality across the national jurisdictions.

Nonetheless, we can share most of its debating points commonly since the ecommunication is universal in strands and mode of interplay. Most importantly, the current focus on the technology primacy needs to be revisited to liaison our beliefs and thoughts with the public value we had held. For example, the symptom of Digital Detoxification may be our reality for some civil group and the open access movement or freedom of expression in the cyber space may contest to conflagrate on its public cause. Cyber terrorism or invasion of privacy would be routinely patronized by public officers and legal scholars. We may retrospect our political or public lives by reverting to one modern thinker, J. Hobbes, a contractarian theorist and champion of absolute monarchy (Owen, 2015). His proposition on the social contract and absolute power of sovereign being had altered a pervious paradigm of politics and thought of community which transformed the central focus of political philosophy from the community to an individual. His philosophy also provoked an importance of sovereign power to protect the life, liberty and property of individuals, hence, the notion of modern democratic theory. A ration and enlightenment ethos had been availed as essential to structure so as to attain two theses simultaneously -- the responsible government and freedom of people (Nunziator, 2009). The sovereign power is only being to monopolize the political power and violence with legitimacy, and interacts with the ideas of Grotius in establishing the cornerstone of international laws. His idea also could influence the thought of Jean Bodin, as generally being received in more emphasis on nation than international community leading to dualism in understanding the international laws. His thought is precious to understand the cyber space and new political discourse in terms of state regulation (Lachman, 2010).

Tim Woo and Christopher Yoo provide an insight in understanding the current debate on net neutrality principle $(2003 ; 2005)$. Yoo's view generally would be an anti-neutrality scholar, who, however, would not argue debasing the equal opportunity of net users or content producers, but oppose an interventionist paradigm and more regulatory frame of government (2005). The distrust and antipathy would properly be matched up with a failed image of Leviathan, and historically tasted in atrocities of two world wars. We would well be known that the kind of post-war thinkers, progressive George Owell and conservative Hayek, had proposed a due response critiquing the monopoly of big and liberal- cause government and abusive power, of course, massively on the capitalism cause (if deregulating or regulating) as well as respect of free contract and liberal market. Yoo's suggestion is simple, but very realistic against the advent of another threat if we insist on the principle of neutrality (2003). From his point of view, the policy makers need to project an evil of monopoly to monstrous telecommunication service, which may go to protect the importance of infrastructure and 
common public service It could perhaps be worse than recasting the utility of net neutrality. On the while, Tim Woo, a progenitor of term, "net neutrality" and perhaps his dissenter, stressed a crucial importance of decentralized innovation than central control, as connected with the end-to-end principle or internet of things (2005).

An improvement of telecommunication infrastructure can also be made with the incessant growth of service providers, the kind of decentralized architect on the basic of internet. He illustrated a trending landscape from Yahoo, to Google and through Facebook and Twitter, which would be impossible to consist with the original frame of oligarchy or monolithic control, perhaps same with the telephone and basic common carrier service. The original frame needs to be cautious to hold as a holistic cure that we may flavor on the historic lessons of dynasties and rules of monarchy. The tragedies of coup or rebellions would not merely an issue of analogy since the same may well be replicated in the prurient interest of enterprises enjoying the status of market dominance. We also can trace examples from history. For example, Bell, now named AT \& T, had collapsed the West Union, and the trust of Edison was overwhelmed by A. Juker, who developed the Hollywood and monopoly of cinema distribution. Beyond the cruelty of economic competition, the failure of net policy also could create a highly problematic challenge that the e-communication is interwoven essentially with the politics, culture, education, and public moral or order of society (Crawford, 2014). 


\section{Reference}

Act of the Information and Telecommunication Service Promotion and Protection of Privacy (2015). ROK Stat. No. 13285.

Berkman, F. (May 20, 2014). "Title II is the key to net neutrality—so what is it?". The Daily Dot.

Brand X Internet Servs. v. FCC, 345 F.3d 1120 (9th Cir. 2003).

Brand X Internet Servs. v. FCC, 2006 U.S. App. LEXIS 1573 (9th Cir., Jan. 23, 2006).

Brauer-Rieke, A.K. (2009). The FCC tackles net neutrality: agency jurisdiction and the Comcast order Berkley Technology Law Journal. 24-1.

Cheng, J. (December 22, 2009). "Comcast settles P2P throttling class-action for \$16 million". Ars Technica (Condé Nast).

Chevron U.S.A., Inc. v. Natural Resources Defense Council, Inc., 467 U.S. 837 (1984), Communications Act of 1934, 48 Stat. 1064

Crawford, S. (2014). Captive Audience: The Telecom Industry and Monopoly Power in the New Gilded Age, New Haven. CT: Yale University Press.

Directive 95/46/EC on the protection of individuals with regard to the processing of personal data and on the free movement of such data. EU Directive 1995.

Eveleth, R. (September 10, 2014). "Why Netflix Is 'Slowing Down' Its Website Today". The Atlantic.

Federal Communications Commission (2005). New Principles Preserve and Promote the Open and Interconnected Nature of Public Internet. DC: Federal communications Commission.

Federal Communications Commission (2006). Re: Notice of Ex Parte Communication in the Matter of Review of AT\&T Inc . and BellSouth Corp Application For Consent to Transfer of Control, WC Docket No. 06-74. DC: Federal Communications Commissions.

Gross, G. (April 6, 2010). "Court rules against FCC's Comcast net neutrality decision". Reuters.

Gross, G. (February 26, 2015). "FCC votes to overturn state laws limiting municipal broadband". CIO Magazine.

Hansell, S, (August 2, 2008). "F.C.C. Vote Sets Precedent on Unfettered Web Usage". New York Times. 
Hu, E. (July 21, 2014). "1 Million Net Neutrality Comments Filed, But Will They Matter?". National Public Radio.

Yoon, J.S. (2010). Laws and Public Policy Concerning the Regulation and Promotion of Internet Service Industry, Justice, Vol. 121, pp. 732-765.

Kim, D. H. (2009). Two Sided Market Framework for Validity Analysis of Network Neutrality Policy Toward the Monopolistic Market Provider, Studies on the Information and Telecommunication Policy, 16-2. pp. 1-45.

Kang, C. (December 22, 2010). "FCC Approves Net-Neutrality Rules; Criticism is Immediate". The Washington Post.

Kim, C.W. (2015). New FCC rules on the net neutrality. Seoul. SK: Korean Information Society Development Institute.

Kim, Kiyoung, On the Fundamentals of Law and Public Policy (April 13, 2015). Available at SSRN: http://ssrn.com/abstract=2593758 or http://dx.doi.org/10.2139/ssrn.2593758.

Lachman, R. (2010). States and Power, Malden. MA: Polity.

Lohr, S. (February 2, 2015). "F.C.C. Chief Wants to Override State Laws Curbing Community Net Services". New York Times.

M.H. (September 10, 2014). "Net neutrality: Faux go-slow". The Economist.

McCullagh, D. (April 6, 2010). "Court: FCC has no power to regulate Net neutrality". CNET. National Cable \& Telecommunications Association et al. v. Brand X Internet Services et al., 545 U.S. 967 (2005),

Nagesh, G. (2014), FCC to Propose New 'Net Neutrality' Rules: Proposal Would Allow Broadband Providers to Give Preferential Treatment to Some Traffic, Washington, DC: Wall Street Journal.

Nate A. (September 21, 2009). "FCC Chairman wants network neutrality, wired and wireless". New York Times.

National Cable \& Telecommunications Association et al. v. Brand X Internet Services et al., 545 U.S. 967 (2005).

Nunziato, D. (2009). Virtual Freedom: Net Neutrality and Free Speech in the Internet Age, Stanford. CA : Stanford University.

NYT Editorial Board (November 14, 2014). "Why the F.C.C. Should Heed President Obama on Internet Regulation". New York Times.

Owen, T. (2015). Disruptive Power: The Crisis of the State in the Digital Age, New York. NY: Oxford University Press. 
Powell, M. (February 8, 2004). "Preserving Internet Freedom: Guiding Principles for the Industry" (PDF). Retrieved July 7, 2014.

Ruane, K.A. (February 20, 2009). "Net Neutrality: The Federal Communications

Commission's Authority to Enforce its Network Management Principles" (PDF).

Congressional Research Service.

Ruane, K. A. (April 29, 2013). "The FCC's Authority to Regulate Net Neutrality After Comcast v. FCC". Congressional Research Service.

Staff (April 24, 2014). "Creating a Two-Speed Internet". New York Times.

Staff (January 16, 2015). "H. R. _ 114th Congress, 1st Session [Discussion Draft] - To amend the Communications Act of 1934 to ensure Internet openness..." U. S. Congress.

\section{Stiegler, Z. (2012). Regulating the Web: Network Neutrality and the Fate of the Open} Internet, New York, NY: Lexington Books.

S.Y. Lee. Net Neutrality and the Stock Market. Retrieved May 13, 2015 from http://blog.naver.com/taeun21/220004354658.

Telecommunications Act of 1996. 110 Stat. 56

The Editorial Board (February 6, 2015). "Courage and Good Sense at the F.C.C. - Net Neutrality's Wise New Rules". New York Times.

Tim, W. (2003). Network Neutrality, Broadband Discrimination. Journal of Telecommunications and High Technology Law, Vol. 2, p. 141. Available at SSRN: http://ssrn.com/abstract=388863 or http://dx.doi.org/10.2139/ssrn.388863.

Yoo. C. S., Beyond Network Neutrality. Harvard Journal of Law and Technology, Vol. 19, Fall 2005. Available at SSRN: http://ssrn.com/abstract=742404.

U.S. Telecom Assn. v. FCC. 290 F.3d 415, 428 (2002).

Verizon Communications Inc. v. FCC, 535 U.S. 467, 489-490 (2002)

Verizon v. FCC, et al., No. 11-1355 (D.C. Cir. 2014)

WorldCom, Inc. v. FCC. 246 F.3d 690, 692 (2001).

Wyatt, E. (November 10, 2014). "Obama Asks F.C.C. to Adopt Tough Net Neutrality Rules". New York Times. Retrieved November 13, 2014.

Weil, N. (February 19, 2014). "FCC will set new net neutrality rules". Computerworld. 


\section{THE REPOSITORY OF PEER COMMUNICATION}




\title{
[WEEK 1]
}

\author{
From: Tina Angela Brooks \\ Alcohol Bev. Control v. Boyd \\ 231 P.3d 1041 (2010)
}

\section{Facts on the Case}

\begin{abstract}
Alcohol Bev. Control v. Boyd. Alcohol Beverage Control (ABC) officers, Tim Davidson and Greg Harris, witnessed Shot Glass bar bartender, Dawn Moler, serve an intoxicated individual, Justin Anderson, an alcoholic beverage. Davidson cited Moler for violation of Idaho Code $\$ 23-615$ because she served the clearly intoxicated Mr. Anderson an alcoholic beverage. Boyd appealed to the hearing officer challenging the constitutionality of the code. The hearing officer ignored the appeal. ABC filed a violation notice seeking suspension of Boyd's license to sell alcoholic beverages citing the action of Ms. Moler's serving alcohol to an intoxicated Mr. Anderson as a violation. The hearing officer suspended Boyd's license based upon the above facts. Boyd appealed to the district court and moved for a stay of suspension based upon the code being unconstitutional and vague. The district court reversed the hearing officer's decision and remanded the case. ABC appealed to the district court regarding the constitutionality of the statute. Boyd did not challenge the district court's conclusion that Moler served alcohol to an obviously drunk person.
\end{abstract}

\section{Issues}

Is Idaho code §23-615 unconstitutional and vague? Title 23 states that "no licensed person or his employed agents, servants or bartenders shall sell, deliver, or give away, or cause or permit to be sold, delivered, or given away, or allowed to be consumed, any alcohol beverage, including any distilled spirits, beer or wine, to any person actually, apparently or obviously intoxicated." I.C. §23-933 states that "the director may suspend, revoke, or refuse to renew a license issued pursuant to the terms of this chapter for any violation of or failure to comply with the provisions of this chapter or rules and regulation promulgated by the director or the state tax commission pursuant to the terms and conditions of this chapter."

\section{Holding}

The Supreme Court of Idaho's decision was to reverse the district court's decision and the case was remanded.

\section{Reasoning}

The reasoning was based the following assumptions:

1. The retailing of alcohol is not a constitutionally protected property right.

2. Liquor license is a grant or permission under governmental authority to the licensee to engage temporarily in the business of selling liquor.

3. The retailing of alcohol is a privilege not a natural right to the licensee.

\section{Analysis}

The Supreme Court's review was based upon the constitutionality of the statute. The agency did not rule on the constitutionality of the statute because they were not authorized to make such a determination. The District court erred in holding because it made the determination that "retailing alcohol was a constitutionally protected property 
right." Marbury v. Madison is cited as presenting the fundamental responsibility of the judiciary is to act in its appellate capacity over the lower court in determination of constitutionality of statutes. The Idaho Supreme Court independently of the district court's decision reviews the agency record making a determination on the constitutionality of statutory enactments.

\section{References}

Alcohol Bev. Control v. Boyd, 231 P.3d 1041 (Ida Sup. Ct. April 23, 2010).

Marbury v. Madison, 5 U.S. 137; 2 L. Ed. 60; (U.S. Sup.Ct. February 24, 1803

\section{Hello Brooks,}

Thank you for the informative post. It is surprising that the state constitution would not provide express provisions relating with the power of constitutional review. As we see, the federal constitution lacks express terms of judicial review, but the progress of US federalism may well create that the state will incorporate the idea of Marbury v. Madison statutorily into their constitutions. I also would be accorded with the argument on the quality of issue between the natural rights and privilege. The natural rights, plainly with the property right, are a matter of constitution distinct from the licensing arrangement with the government. How do you assess or expect that the Supreme Court has done or will do interact with the theme of property right in the progress of age? Do you agree on the conservatives that the restriction of property rights should pass a stricter scrutiny as in the cause of libertarianism? In the recent decision, the Supreme Court created a progressive rule on the net neutrality, a staggering issue awaiting any new paradigm. How do you find its persuasion and practical consequence? Respectfully.

Author: MONIKA TALLEY Date: Thursday, March 5, 2015 1:41:15 AM EST Subject: RE: Discussion 1 - Week 1 Main Post Muskrat v. United States (1911)

$$
\text { Monika C. Talley }
$$

Marbury v. Madison (1803) is considered a landmark case because Chief Justice John Marshall's decision that allowed the courts to strike down laws and executive actions as unconstitutional (Vile, J. R., \& Menez, J. F., 2010, p. 104). This action made the legal doctrine of judicial review become more salient, which assumes the right of the Supreme Court to supervise the laws of Congress. According to the review done by Davison Douglas in the Wake Forest Law Review in 2003, Marbury v. Madison (1803) was not frequently cited for its authority granting judicial review. Constitutional law treatises were more likely to cite this case for its decision of writs of mandamus or the Supreme Court's original jurisdiction. This case is considered significant because it further defined the separation of powers while posing a challenge to it through the execution of checks and balances to make sure no law is made that is in conflict with the U.S. Constitution. Therefore, on one hand, it allows the utmost protection of liberty and citizens' rights; however, on the other hand, the concept of judicial review may be seen as an infringement upon the public's agenda through the work of elected officials legislating on their behalf. 
The Supreme Court case I reviewed is Muskrat v. United States, 219 U.S. 346; 31 S. Ct. 250; 55 L. Ed. 246 (1911). The significance Marbury v. Madison (1803) had on this case is that it didn't grant the Supreme Court authority to judge the validity of an act of Congress as an abstract question because the intent of the Constitution only extends the notion of judicial power to "cases and controversies". Therefore, the legal precedent set by the Marbury v. Madison (1803) case doesn't go as far as challenging an act of Congress based upon the validity of a class of legislation reason being that Marshall's decision applied to suits "instituted according to the regular course of judicial procedure" (Vile, J. R., \& Menez, J. F., 2010, p. 120-121).

\section{References}

Douglas, D. (2003). Symposium article: The rhetorical uses of Marbury v. Madison: The emergence of a "great case." Wake Forest Law Review, 38(2), 375.

Muskrat v. United States, 219 U.S. 346 (1911)

Vile, J. R., \& Menez, J. F. (2010). Essential Supreme Court decisions: Summaries of leading cases in U.S. constitutional law. Lanham, Md: Rowman \& Littlefield Publishers.

Hello Monika,

I enjoyed reading your post. Your interest between the work of elected officials and judiciary seems to be related with the last comment, "instituted according to the regular course of judicial procedure." As a matter of legal logic, the judicial decision of unconstitutionality has an impact within the house ambit so that the lost parties only shall be bound. Along with the development of media and increasing interchange of public, the laws repugnant to the Constitution perhaps rarely could survive without the repeal. In some cases, however, the public would contend and disagree on the decision of Supreme Court utilizing a media and public forum. Oftentimes, nevertheless, the public authorities including the Congress, state legislatures, and government agencies, would import the rulings to conform with their responsibilities. Hence, the context of interplay would be dynamic and lively indeed. Comparatively, however, some foreign jurisdictions would institute an abstract nature of review or a priori review system which differs from the US case. It tends to provide a certainty and uniformity of national actions. How do you see any rationale if the Constitution prefers the individualized effect other than abstract and general invalidation? Respectfully.

Hello Sheron,

Thank you for the good post. I agree that the people of colonial period would take the Constitution as the kind of political documents or declarations to found their new regime. It is ironic that the colonial states had a same name of law, constitution, but also not a law until the judicial practice had been settled upon the decision. I suppose of two clues. One is that the time had been under the rule of monarch, the kind of dictatorship in modern sense. The dictate of monarch may have been absolute that the concept or belief of public law other than civil disputes would be absent or far meeker. The other is that the provisions of Constitution are highly abstract as seen to lack the quality of laws for the common law lawyers. It would be same if the civil law countries have a general quality of civil code nowadays and that the common law lawyers would be strange if it is any law of appreciable quality to be applied to 
the specific contractual dispute. In the same manner and within the context of international laws, the contemporary US courts would highly be reluctant to apply the treaties unless the treaty language is specific and detailed so as to be applied. In the end, the rule of law ideals would compel many new arrangements of public lives that the reception of Constitution in new land as law seems revolutionary into all scope of public laws beyond the judicial review. How do you find a trajectory of Supreme Court meritorious to support the national union since the decision was rendered? Respectfully.

Author: Sheron Hendrix Date: Thursday, March 5, 2015 12:36:50 PM EST Subject: RE: Discussion 1 - Week 1

\section{Dred v. Sandford, 19 Howard 3931857}

In the case of Marbury v. Madison, 5 U.S. 137 (1803), the Judiciary Act of 1789 in Section 13 had provided that the Supreme Court could issue writs of mandamus (writ issued by a court to compel performance of an act) (p. 105). The first time the Supreme Court asserted issuing a writ of mandamus was over congressional laws in Chief Justice John Marshall's decision in (Marbury v. Madison, 1803), requiring Secretary of State Madison to deliver to Marbury his commission (p. 105). The Marbury v. Madison case is a landmark decision because for the first time in history, the Supreme Court declared an act of Congress unconstitutional, and thus established the doctrine of judicial review (p. 105).

More significantly, the Constitution is law, and therefore it is the job of the courts to say what the Constitution means (PBS, 2006). Marshall's interpretation about the Constitution being law was in some sense revolutionary; Marshall's real significant and unique contribution was to view the Constitution as law, so Marshall, in that decision, established the role of the Supreme Court as interpreter of the Constitution (PBS, 2006). The Court had to repeat this process again fifty years later in the case of Dred v. Sandford, 19 Howard 393 (1857) (p. 106).

PBS. (2006). Supreme Court Chief Justice John Roberts: On John Marshall's contribution to the American law and politics. Retrieved from

http://www.pbs.org/wnet/supremecourt/bonus/john1.html

Vile, J. R. (2010). Essential Supreme Court decisions: Summaries of leading cases in U.S. constitutional law. Lanham, Md: Rowman \& Littlefield Publishers.

Hello Clayton.

Thank you for the excellent post. I also see much implication from the statement of Schauer, "role is not to decide the policy question but to decide who is to decide the policy question." The controversy may even be present within the national judiciary of complex system, such as Korea that has a dual hierarchy between the Supreme Court and Constitutional Court. In that case, the problem is more incurable since the ultimate unitary authority is not available unlike the US case. I also consider the stare decisis rule may retard the superannuated quality of case laws, which actually arose as an issue of legal reform around the 1970's of British judiciary. I respectfully disagree, however, if the rule has no utility at all, since the republics need some of legal stability and predictability. I suppose that the rule can be handled within the wisdom and conscientious minds of judges to adapt with the social change. How do you 
comparatively assess the strengths or weaknesses if Germany has six types of Supreme Courts other than one unitary Supreme Court? Respectively.

Author: Precious Clayton Date: Friday, March 6, 2015 12:07:40 AM EST Subject: RE: Discussion 2 - Week 1

Post a brief explanation of the Supreme Court's role in policy making. Then describe two strengths and two limitations of the Supreme Court's role in policy making.

The Supreme Court plays a very important role in our constitutional system of government. First, as the highest court in the land, it is the court of last resort for those looking for justice (About the Supreme Court, (N.D)). Second, due to its power of judicial review, it plays an essential role in ensuring that each branch of government recognizes the limits of its own power (About the Supreme Court, (N.D)). Third, it protects civil rights and liberties by striking down laws that violate the Constitution (About the Supreme Court, (N.D)). Finally, it sets appropriate limits on democratic government by ensuring that popular majorities cannot pass laws that harm and/or take undue advantage of unpopular minorities (About the Supreme Court, (N.D)). The supreme courts role in policy making as stated in Schauer (2006) states the Court's "role is not to decide the policy question but to decide who is to decide the policy question'") (Schauer,2006). These decisions are constitutive because they play a major role in establishing which institutions will be making the first-order policy decisions(Schauer,2006).

The Strengths of the of the supreme courts role in policy making is the Constitution and the Supreme Court does address, "persistently is decide how policy will be made" (Schauer, 2006). Another strength would be once the Supreme Court has ruled a policy unconstitutional it has the power to alter the policy to be in compliance with the Constitution (Vile ,2010).

The limitations of the of the supreme courts role in policy making is that it the concept of stare decisis, or adherence to the decisions made in prior cases, limits the range of the Court's discretion(Schauer, 2006). Absent extraordinary circumstances, the Supreme Court will follow precedent - the cases it has previously decided. The appearances of democracy can be limited for those pro judiciary as many believe that policy making should be "responsive to the popular will of the people" (Schauer, 2006).

About the Supreme Court (N.D). Retrieved from http://www.uscourts.gov/educationalresources/get-informed/supreme-court/about-supreme-court.aspx

Schauer, F. (2006). The Supreme Court 2005 term: Foreword: the court's agenda - and the Nation's. Harvard Law Review 120(1), 5-64.

Vile, J.R. (2010). Essential Supreme Court decisions: Summaries of leading cases in U.S. constitutional law. Lanham, MD: Rowman \& Littlefield.

Hello Annie.

I have enjoyed your post. The earlier cases would deal with structural issues, such as taxation of state upon the federal banks or so, since the Constitution allowed vacuums and ambiguities. Given the nationalization of US had well completed, do you see if any earlier cases of 
structural issue must be re-meditated unless the language of Constitution is firmly clear? I also share your thought that the Courts must wait for the controversy to get mature amenable to the judicial review or that the rights have been violated. How do you consider the activism of judiciary in the environmental issues? Do you see the environmental group could be a right plaintiff for the controversial governmental action? Respectfully.

\section{Annie Scott-Douglas}

RE: Discussion 2 - Week 1 (Scott-Douglas)

\section{Week1Disc 2}

Role of the Supreme Court in Policy Making

The Supreme Court was established by the Constitution. The Court shares power with the legislative and executive branches of the government to interpret the Constitution. The Supreme Court is considered to be the final authority on court rulings. Vile (2010) suggest that important cases frequently originate from earlier centuries and that cases often focus on technical cases that are not generally understood. The Supreme Court being independent of the legislative and executive branches has the power to decide law.

Article III of the Constitution of the United States (Article III, n.d.) defines the power of the Supreme Court. The Court has the power to determine the constitutionality of federal and state statutes. Additionally, cases decided at a lower court can be appealed to the Supreme Court. The Court has the power of judicial review. In other words, actions of the legislative and executive branches of the government are subject to review and can be ruled as invalid by the Supreme Court.

The Supreme Court, although powerful in the sense of deciding law, cannot enforce its rulings nor can the court itself challenge the constitutionality of an issue. The Supreme Court must wait until the injured party alleges that an issue is unconstitutional or that rights have been violated before it can hear the case. Further, the Supreme Court can only hear issues from a lower court that it can remediate.

\section{References:}

Article III, U.S. Constitution, (n.d.). Retrieved from https://www.law.cornell.edu/constitution/articleiii

Vile, J. R. (2010). Essential Supreme Court decisions: summaries of leading cases in US constitutional law. Rowman \& Littlefield Publishers.

Hello Tracee.

I enjoyed your post. The check and balance had deemed "essential" in the classic age if to ensure the liberty and life interest. I suppose if it is "operative" still in these days although the democratic lesson had well been received by the contemporary power holders, but may pose challenges in some area of concern. If the war emergencies threat the nation, a seizure of still 
industries might be necessary to protect the American army and citizens. I wonder if the property rights of industry owners or protection of union could be compensated later at the aftermath of war. How do you find the persuasion of court ruling in this aspect?

Author: TRACEE GOODMAN Date: Saturday, March 7, 2015 1:49:53 AM EST Subject: RE: Discussion 2 - Week 1

Supreme Court's Policy Making Authority

The Supreme Court's role in policy making stems from the judicial review process and the courts authority to determine the constitutionality of a legislative act. The Supreme utilizes the power granted to it by Article III of the US Constitution to define the scope and nature of the powers and separation between the legislative and executive branches of the federal government. The Court utilizes the judicial review process to interpret the law and determine the constitutionality of an action. Further, The Court's decisions can be used to impose limitations on the scope of Executive authority, (see Humphrey's Executor v. United States (1935), and Youngstown Sheet \& Tube Co. v. Sawyer (1952), Vile, 2010)

\section{Weakness}

The Supreme Court cannot make law or policy without there first being a case presented to the court for judicial review. Thus, if there is need for policy in a particular area of law, one cannot be proposed by the Court unless there is a case being reviewed that addresses that particular issue. Further, the Supreme Court does not directly enforce its rulings, but it relies on respect for the Constitution and for the law for adherence to its judgments. (Vile, 2010)

Strength

One strength of the Supreme Court and its ability to determine the constitutionality of an act of congress or a law. This authority has been use to check the Federal Government in cases such as find that president Truman had acted unconstitutionally in ordering the US Army to take over US steel Plants in 1952. The authority to determine constitutionality serves as a system of checks and balances. (Youngstown Sheet \& Tube Co. v. Sawyer, 1952)

Resources

Humphreys' Executor v. United States 295 U.S. 602 (1935)

Vile, J. R., (2010). Essential Supreme Court decisions: Summaries of leading cases in U.S. constitutional law. Lanham, Md: Rowman \& Littlefield Publishers.

Youngstown Sheet \& Tube Co. v. Sawyer, 343 U.S. 579 (1952) 


\title{
[WEEK 2]
}

\author{
Hello Chinwe
}

I have enjoyed reading your post. In implications, it seems if the Nigerian democracy was influenced both by liberal and social institutions of law. The "legality of state" or strict adherence with the notion of social contract often would be alleged in align with the collectivity of society. The role of Supreme Court, however, is heard that it assumes a crucial responsibility to defend individual rights, probably, stemming from the tenet of liberal market. Since I am not well read of Nigerian history, it may be facial, but in my knowledge, the British legal system perhaps would be major influence in laying the legal system of your nation. Geographically or in interchange of civilization, the French tradition also could be mixed as in the case of former Soviet Union. As we see, the USSR, former of Russian Federation has a trait of "legality of socialist law," and emphasized the superiority of collegial body over the judicial power. How is the legal or political system of Nigeria structured? Does it endorse a socialist party as legitimate and permissible? Is it the separation of powers principle safeguarded as a matter of constitution? Respectfully.

Author: CHINWE MORDI Date: Thursday, March 12, 2015 5:17:24 AM EDT Subject: RE: Discussion 1 - Week 2

\section{THE SUPREME COURT AS THE FINAL DECISION MAKER}

The Supreme Court as the name implies is the supreme/topmost court of the land. In the Nigerian Constitution (Nigeria, 1999), it states that the Supreme Court is the court of final decision and no appeal can be brought to any other court on the decision of the Supreme Court. The situation is the same with the Supreme Court in the US. The Supreme Court is a part of the judiciary arm of government who is empowered with the duty to interpret laws. In carrying out this act, the Supreme Court has been known to step in to create policy that in some cases, defines the powers of the other arms of government and also protect the rights of the individual (Graglia, L.A., 1994). While the Supreme Court cannot unilaterally take up a case in order to redress a wrong done to an individual, when such a case comes before the Supreme Court, it adjudges the case in a manner to determine the constitutionality or otherwise of the subject in issue as was done in the case o Marbury v Marshal. Furthermore, the supreme court acts as the custodian of legality for the state which in a democracy, the people have by social contract handed over some of their rights to the government in exchange of protection and provision and as a custodian, the supreme court is seized with the responsibility of protecting the right if the individual where necessary. An example of this is the case of Kyollo v. United States (2001) in this case, the law enforcement agents used thermal imaging to detect hot spots outside of Kyollo's apartment and based on that information, obtained a warrant to search his apartment. Upon searching his apartment, it was discovered that Kyollo was growing marijuana. The Supreme Court held that the use of thermal imagining amounted to an illegal search and a violation of the individual rights of Kyollo.

An advantage of the Supreme Court being the Final decision making court is that there is an end to litigation. This is necessary because litigation cannot continue in perpetuity, there has to be an end and the Supreme Court as the final decision making body makes that possible. Also, since it is only the Supreme Court that can overrule itself, being the final decision 
making body ensures that a common standard is held. On the other hand, a disadvantage of the Supreme Court being the final decision making body Is that only a handful of people whose decisions may be coloured by personal biases have the final say on a policy or right that affects a whole country without any opportunity for the public to appeal the decision.

\section{References}

Nigeria, C. t. (1999). Constitution of the Federal Republic of Nigeria.

Graglia, L. A. (1994). Do judges have a policy-making role in the American system of government? Harvard Journal of Law \& Public Policy, 17(1), 118-130.

Hi. Tina,

Thank you for the excellent post. You stated, "one of the strengths the Supreme Court is the perception legislators and the public have concerning its decisions." I am also sympathetic with your view, and may add that the federalism as well as bicameralism had increased that perception. The legislators of unitary government and single chamber of national congress may be disposed with discrete recognition or sensibility if the judicial people lack a political representation. Some argue if the draftsman of Constitution saw a judicial branch most effective to protect their new wealth in land, which also may be implied of the federalist papers. Their intention would prefer somewhat weak Congress with two chambers, perhaps from the idea of divide and rule. Besides, it is a matter of nature that the state legislators are most proper to revere the rule of Supreme Court as their standard of action given the public issues being generally uninterested and dispassionate. The power struggle was systemically foreclosed to be residual with the conservative judiciary perhaps inculcated over history and deeply with a private or liberal virtue as we feel with the common law legal traditions. Reinhardt's view may not be improper, stating if the judiciary had been massively for liberal cause other than moral. Practically also do we tend to find limited number of federal legislations struck down over history other than state pieces. Marbury v. Madison and New Deal legislations are notorious which implicate respectively the earlier of most foundational technical issues and transformative quality of cases from the liberal to social welfare state. How do you see it morally more desirable between the unitary system of national administration and US type?

Author: Tina Brooks Date: Wednesday, March 11, 2015 11:15:30 PM EDT Subject: RE: Discussion 1 - Week 2: Main Post

Supreme Court's Role in Protecting Individual Rights

Tina Angela Brooks

\section{Supreme Court's Role in Protecting Individual Rights}

The United States Supreme Court is the only branch of government that does not require members to be reelected after a term. This lifelong appointment allows the members of the Court liberties within the perimeter of their appointment to incorporate personal beliefs, values, and biases into the decisions they render. The Court's decisions are accepted as policy by legislators and the public magnifying the power given the Supreme Court by the Constitution (Graglia, 1994). They also act as a shield between individual rights protected 
by the Constitution and Corporate rights that infringe on the individual rights (Vile, 2010). The purpose of this post is to briefly explain the role of the Supreme Court in protected individual rights and some of the strengths and weakness of the Court as final individual rights cases decision maker.

\section{Weakness}

The United States Supreme Court has the power to void or nullify state laws that infringe on the rights of the citizens (Miranda v. Arizona). Criteria for the Court's decisions are usually based upon whether the plaintiff is an interested party, an individual or group of people with something to gain or loss from the decision, and if the problem is real and exists. The Courts will not make a decision based upon speculation of future events (Roe et al. v. Wade, 1973). Another weakness of the Court is that its members inflict their values and biases upon the decisions and opinions (Graglia, 1994). Abortion laws are based upon personal beliefs, religious, and personal values as well as medical studies. The final decision on topics where time is of the essence may compound the problem rather than provide the plaintiff with relief. This inability to make decisions before damage is done is a major weakness in the Supreme Court's ability to proactively influence policies to protect individuals' rights.

\section{Strength}

One of the strengths the Supreme Court is the perception legislators and the public have concerning its decisions. Legislators and the public accept Supreme Court decisions as policy without challenging the validity of whether it is in correlation with the Constitution (Graglia, 1994). The Supreme Court decision that abortion is a privacy protected by the Constitution during the first two trimesters. The Supreme Court has the power to interpret the Constitution without fear of retribution by the public (Vile, 2010). An example is the Miranda v. Arizona case, when the Court decided law enforcement is required to read to people in custody their rights and that information obtained without reading them their rights is inadmissible in court.

\section{Conclusion}

The Court's role in determining policies that protect individual rights is reactive to infringements already placed upon individuals. These reactive decisions result after someone has borne the infringement created by another; because decisions take considerable time, irreversible damage can result before a final decision is rendered. The greatest Strength in the Courts policy role concerning individual rights may be in the perception of legislators and the public that the Court's decision is policy or law.

\section{References}

Graglia, L. A. (1994). Do judges have a policy-making role in the American system of government. Harvard Journal of Law \& Public Policy 17(1), 118-129.

Miranda v. Arizona 384 U.S. 436 (1966)

Roe et al. v. Wade 410 U.S. 113 (1973)

Vile, J.R. (2010). Essential Supreme Court decisions: Summaries of leading cases in U.S. constitutional law. Lanham, MD: Rowman \& Littlefield. 
Hi Professor and Annie,

Thank you for the question. In my knowledge, the public university other than private schools shall respect the Constitution and its mandate. That is because that the Constitution technically is the law of public relations and creates an obligation imposed on the government and government- related instrumentalities. Since it is the nature of public law, the private sphere of lives remains free with the freedom of contract and self-determination.

Hence, the choice of students and their parents is most paramount to enter the private schools, which effectively impedes their argument on the basis of Constitution. An earlier thought that the Constitution is a set of bill of rights implying its fundamental trait as a bulwark of newly born liberty virtue gradually had taken a new perspective that the document bears "national" morals beyond the "public" ones. This leads, as assumed, to change the paradigm of Constitution between the "public and private" that private entities may be regulated in the cause of Constitution in some distinct area. The state action theory is a legal invention to convert granting a same identification of influential private entities with the government. I am not certain, however, if you can find any constitutional debate on the private schools. Since we talk about the difficulties of judicial activism, I may be proper if the state action theory would not be expansively used.

As responded with Chinwe, the civil law traditions prefer a collectivity and public unity in dealing with the public questions of structure and social justice (Kim, 2015). This trait generally results in an extreme of spectrum or weaknesses (i) the collective action of nation would be cherished that yields the kind of institutions, e.g, plebisit or referendum, as supreme in deciding the public issues, implying an important odd to indent the parliamentary democracy and concept of democratic or legal process (ii) it, on the other, could procreate a national dictatorship to subject the people as passive and thrust into a haunted rule (iii) most loyal to the dualism between the public and private. The strengths will lie (i) the system may well be sensed with our ideals or traditional concept of polity (ii) effective and efficient administration would be more realistic (iii) public unity can remain sacred (iii) can achieve a more cost-efficient decision making and precludes an unnecessary consumption of resources with expensive judiciary.

In comparative institutions, we may imagine three types of response to resolve the conflict of basic relationship between the state and people. The first one is constitutional review a priori, in which special agencies in the executive would review and give an opinion to the end stage of legislation. The second type is those of post review upon the eruption of disputes about its constitutionality. In a considerable number of civil law countries, we can find the mixed system of review that both ways are ensured as a matter of institution. Although it is not a matter of national constitution, I may illustrate an example of WTO. The scholars of international trade tend to have a view that the WTO is the kind of world economic constitutionalism. It instituted a dual response, the kind of mixed system, that one is the TPRM (Trade Policy Review Mechanism) and the other is a dispute settlement mechanism. TPRM would be the kind of a priori measure and DSM is that of post review. In my view, the post review would be most dynamic to increase the constitutional culture and diversity of society, next with mixed system and least with that a priori. While I see a tendency on progress about openness of government with the public, it perhaps would be a less attractive option that we protect the confidentiality or sanctity of sovereign power. I 
prefer the kind of progress, say, increased profile of FOIA, e-government, public disclosure of Supreme Court decision in its public website, open access movement of SSRN (academic), recent decision of progressive nature on net neutrality, and many others. One may like to know and participate that Korean people were exhilarating with the 1987 constitutional reform, in which an aggrieved individual can directly file a constitutional complaint. This reform is alleged to promote at considerable degree the constitutional democracy and culture of public learning. Respectfully.

Kim, Kiyoung, Ethics, Law and Social Justice (April 10, 2015). Available at SSRN: http://ssrn.com/abstract=2592876 or http://dx.doi.org/10.2139/ssrn.2592876.

Author: Kevin Fandl Date: Wednesday, March 11, 2015 10:52:01 PM EDT Subject: RE: Discussion 1 - Week 2

Thank you for this useful comparison of the Korean system. In a civil law system like that, constitutional cases are often reviewed by a special court before those issues become law. Once they become law, they are not often open to challenge. How would you compare that to the system in the United States, that is only reactive and only responds to individual challenges?

KJF

Author: Annie Scott-Douglas Date: Wednesday, March 11, 2015 7:56:21 PM EDT Subject: RE: Discussion 1 - Week 2

Kiyoung:

Can a University limit a student's First Amendment rights? What argument can you make for your response?

Annie

Hi. Whitney,

Thank you for the informative post. Given technicalities of criminal law and conditions of instability or duress, the defendant under the custodial interrogation will certainly be prejudiced in terms of fair trial. Along with the jury trial and right of indigents to counsel, we see the Miranda warning indispensable to protect a constitutional value. If one patient is cautioned of deep state of cancer or other fatal disease, we may neither be inapposite nor get furious if both players, say, the patient and medical doctors, were put in a worship without an interchange of any communication to carry through a medical operation, which may eventually fail to enliven. In some distinct case, however, the patient may not expect for such serious consequence, but death may be caused during a dental treatment or cosmetic operation. The least possibility actually happened that the dental doctors or plastic surgeons had learned in the corner of medical books in his student years. A drug to put the patient under anesthesia reacted fatally against the life of treated patients although the odd is least and that would not happen with a normal person in 99.9 percents of probability. The worship 
in this case probably goes in inverted way that the caution and adequate informing about diverse possibilities from his operation are any of strong importance. Otherwise it is obviously true that we face a challenge. The jury trial also has a strand against the political plot or dominance as we know seven bishops with James II in his attempt to negate the parliament. How much are you sympathetic with the traditional principle, "one innocent man shall not be punished even if hundreds of guilty defendant were to be exonerated," if the criminal dispute is political or apparent of its nature? Respectfully.

Author: Whitney Root Date: Thursday, March 12, 2015 11:39:44 AM EDT Subject: Main Post Discussion 2 - Week 2

\section{Due Process}

\section{Miranda v Arizona}

After Ernesto Miranda was arrested for rape, taken to trial, and subsequently convicted of the crime, questions arose as to the constitutionality of the proceedings regarding his written confession to police. Despite producing a signed confession by the defendant, it was argued to the Supreme Court that the $5^{\text {th }}$ and $6^{\text {th }}$ Amendments were violated since Miranda wasn't informed of his right to counsel, his right to remain silent, and the ultimate use of his confession in a court of law. Ultimately the Supreme Court would rule that, since Miranda was not made aware of his rights prior to being questioned, both the $5^{\text {th }}$ and $6^{\text {th }}$ Amendments were violated and his confession could not be used in court (Vile and Menez, 2010). Specifically, it is stated that, "The prosecution may not use statements, whether exculpatory or inculpatory, stemming from custodial interrogation of the defendant unless it demonstrates the use of procedural safeguards effective to secure the privilege against self-incrimination" (Howard and Rich, 2006, pg 692)

The most obvious and apparent change to policy in response to the Miranda $v$ Arizona ruling came in the form of a requirement, by law enforcement, to begin reciting the 'Miranda warning' to individuals being taken into custody. Defined as an "explanation of rights that

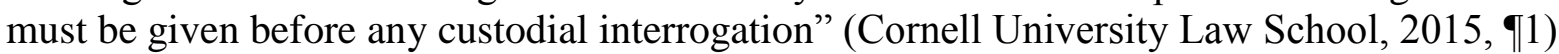
the 'Miranda warning' ensures that an individual being taken into custody is made aware of his right to remain silent, right to an attorney, and the fact that anything he says can be used against him in a court of law (Cornell University Law School, 2015).

Following the Miranda $v$ Arizona ruling, and the subsequent 'Miranda warning' requirement, Congress passed the Omnibus Crime Control and Safe Streets Act. The Act, passed in 1968, included a provision that had clear intent to reverse the Supreme Court's 'Miranda warning' rule. When complaints suggested that too many criminals were being allowed to go free in response to the ruling, the Act added the provision that "whether the defendant received his or her Miranda warnings was only one factor to be considered by the court when assessing admissibility of the confession" (Howard and Rich, 2006, pg 697). A series of other factors were to be considered including time elapsed between arrest and arraignment (Howard and Rich, 2006). Despite the passage of the Act in 1968, it would be 1999, in the case of United States $v$ Dickerson, before the provision would be used (Howard and Rich, 2006), when Dickerson failed to be read the 'Miranda warning' by the FBI (Case Briefs, 2015). The Supreme Court upheld its original Miranda ruling (since Congress cannot overrule the decision), striking down the provision within the Omnibus Crime Control and 
Safe Streets Act (Case Briefs, 2015). The 'Miranda warnings' ruling was upheld and is still used today despite some minor alterations.

In 2010 the Obama Administration considered seeking legislation to further interpret the ruling in regards to terrorist suspects and the timeframe involved in issuing the Miranda warning. The Federal Bureau of Investigations (FBI) issued a memorandum urging agents to interrogate suspected terrorists without necessarily reading them their Miranda rights. The legislative proposal was refused by Congress (Savage, 2011).

\section{References}

Case Briefs. (2015). Dickerson v United States. Retrieved from, http://www.casebriefs.com/blog/law/criminal-procedure/criminal-procedure-keyedto-israel/police-interrogation-and-confessions/dickerson-v-united-states-2/

Cornell University Law School. (2015). Miranda warning. Retrieved from, https://www.law.cornell.edu/wex/miranda_warning

Howard, R, and Rich, L. (2006). A history or Miranda and why it remains vital today. Valparaiso University Law Review, 40(3), 685-706. Retrieved from, http://scholar.valpo.edu/cgi/viewcontent.cgi?article=1225\&context=vulr

Savage, C. (2011). Delayed Miranda warning issued for terror suspects. Retrieved from, http://www.nytimes.com/2011/03/25/us/25miranda.html

Vile, J. R., \& Menez, J. F. (2010). Essential Supreme Court decisions: Summaries of leading cases in U.S. constitutional law. Lanham, MD: Rowman \& Littlefield Publishers.

\section{Hi Bronia.}

I have enjoyed reading your post. Your brief on the two policies involving the public school students raises an interesting point. The condition is highly analogous if the culpable students are virtually custodial and the criminal implications or odd of development often is likely. Most crucially, however, the relationships are educational, so that the kind of trust, respect and mutual affection are highly expected. In other aspect, however, the juveniles are less in capacities generally to appreciate and comprehend the nature and quality of events or process. That would also be true on the teachers' side since they are not trained or knowledgeable investigators or police officers. Hence I am concerned if the constitutional privilege would see it plausible to fall within the school autonomy. How do you distinguish various types of public organization, professional organizations, labor union, and public church in applying the rules of Supreme Court? Respectfully.

Author: Bronia Ashford Date: Thursday, March 12, 2015 8:34:59 PM EDT Subject: RE: Discussion 2 - Week 2 (Bronia)

\section{Brief description of the case you selected.}

Miranda v. Arizona. 
In the case of Miranda v. Arizona, the Supreme Court made a decision that "addressed four different cases involving custodial interrogations" (Miranda v. Arizona, 1966). This case has been used to support several rulings on the Federal, State, and local level. The court decision provided guidance on two central issues. First, "statements obtained from an individual who is subjected to custodial police interrogation are admissible against him in a criminal trial " (Miranda v. Arizona, 1966). Second, is if "procedures which assure that an individual is accorded his privilege under the Fifth Amendment to the Constitution not to be compelled to incriminate himself" (Miranda v. Arizona, 1966).

The ruling made in Miranda v. Arizona concluded that "the prosecution may not use statements, whether exculpatory or inculpatory, stemming from custodial interrogation of the defendant unless it demonstrates the use of procedural safeguards effective to secure the privilege against self-incrimination. By custodial interrogation, meaning that questioning initiated by law enforcement officers after a person has been taken into custody or otherwise deprived of his freedom of action in any significant way."(Miranda v. Arizona, 1966). Subsequently, the court ruled that "a defendant "must be warned prior to any questioning that he has the right to remain silent, that anything he says can be used against him in a court of law, that he has the right to the presence of an attorney, and that if he cannot afford an attorney one will be appointed for him prior to any questioning if he so desires."(Miranda v. Arizona, 1966).

\section{Two policies that were influenced by the case}

The Miranda decision is utilized to describe how school officers interact with students in the school system. "Legal scholars agree that public school students involved in school-related disciplinary infractions are not entitled to a Miranda warning prior to being questioned by school authorities."(Vacca, 2006). There are challenges with this decision as there has been an increase in violence in schools. In many instances, school officials may interview youth before the police are involved. The Miranda case decision supports education policy that "“"the Fifth Amendment privilege is available outside of criminal court proceedings and serves to protect persons in all settings in which their freedom of action is curtailed in any significant way from being compelled to incriminate themselves."(Vacca, 2006).

For youth, there have been debates on their understanding of Miranda rights. Empirical studies have shown "investigating juveniles' comprehension of the Miranda warning indicate that they tend not to understand the warnings" (Colwell, 2005). As a result, some research has shown that "age and intelligence are factors that affect comprehension and understanding of Miranda" (Colwell, 2005). The justice system must ensure that laws, policy, and procedures relating to juveniles are appropriately adopted. As a result, policy regarding Miranda rights to minors require "Changes in the juvenile justice system toward a better understanding of adolescents' capacities as legal decision makers" (Colwell, 2005)

\section{$\underline{\text { References }}$}

Fifth Amendment: Miranda V. Arizona and Criminal Defense. (n.d.). Retrieved from http://www.uscourts.gov/uscourts/educational-resources/get-involved/constitutionactivities/fifth-amendment/miranda-criminal-defense.pdf 
Colwell, L. H., Cruise, K. R., Guy, L. S., McCoy, W. K., Fernandez, K., \& Ross, H. H. (2005). The influence of psychosocial maturity on male juvenile offenders' comprehension and understanding of the Miranda warning. Journal of the American Academy of Psychiatry and the Law Online, 33(4), 444-454.

Goldstein, N. E. S., Condie, L. O., Kalbeitzer, R., Osman, D., \& Geier, J. L. (2003). Juvenile offenders' Miranda rights comprehension and self-reported likelihood of offering false confessions. Assessment, 10(4), 359-369.

The Influence of Psychosocial Maturity on Male Juvenile Offenders' Comprehension and Understanding of the Miranda Warning. (n.d.). Retrieved from http://www.jaapl.org/content/33/4/444.full

Price, P. (2009). When is a police officer an officer of the law?: The status of police officers in schools. The Journal of Criminal Law and Criminology, 541-570.

Thurau, L. H., \& Wald, J. (2009). Controlling partners: When law enforcement meets discipline in public schools. NYL Sch. L. Rev., 54, 977.

Vacca, R. S. CEPI Education Law Newsletter.

Hi. Annie.

Thank you for the good post. The two cases you illustrated imply that the Court saw an efficient and workable process of criminal investigation important to remain intact from the impact of Miranda decision. This dialectic interaction between the Court and public agencies likely scores increasing a meritocracy of government. I also consider, on the other hand, that the Court reporting would not be a minimal factor to effect the rule of law. It actually had been one of critical issue over history who publishes or eviscerates the main holding of Court, for example, between the commercial businesses and Court itself or some executive unit. Given if the Court is most adequate to deal with that publication business, that is not always the case as nations and history are illustrated. Since we discuss the role of Court in making a public policy, how do you find legitimate or effective if the commercial businesses undertake the work of importance besides the firsthand of court opinion, perhaps without a main holding in format? Respectfully.

Author: Annie Scott-Douglas Date: Thursday, March 12, 2015 11:51:51 PM EDT Subject: RE: Discussion 2 - Week 2 (Scott-Douglas)

WK2Disc2, Scott-Douglas, A.

Due Process

Summary: Ernesto Miranda was arrested for kidnapping and rape, however, during interrogations, police officers did not inform Miranda of his rights. After hours of interrogation, Miranda signed a confession. The government did not inform Miranda of his rights under the Fifth Amendment (Vile, 2010). Although Miranda v. Arizona (1966) included four cases, I am only discussing Miranda in Miranda v. Arizona (1966). 
Issues: Was the government required to inform Miranda of his rights? Does the Fifth Amendment forbid any pressure against self-incrimination? Does Miranda have a remedy?

Holding: It was held that the government should have advised Miranda of his right to counsel, right to remain silent, right to have counsel appointed, and an explanation that anything he say could be used against him. The holdings are policies that were influenced by the case.

Miranda's (1966) confession was not used in court and because law enforcement failed to read Miranda his rights, he was not afforded due process under the Fifth and Fourteenth Amendments of the Constitution of the United States.

Police officers and members of the law enforcement community at the state and federal levels have been affected by the Supreme Court decision. The Miranda v. Arizona (1966) ruling led to officers implementing the requirement that suspects be advised of their rights upon arrest and before interrogations begin. Due process is a policy that was influenced by the ruling along with having an attorney present during questioning which includes appointing an attorney for suspects that cannot afford an attorney.

In Davis v. United States (1971), Judge Rehnquist ruled that police are not required to stop interrogating suspects who ask to have an attorney present during questioning. In Harris v. New York (1994), the Supreme Court ruled that statements made by a suspect, although not advised of rights, could be used to establish credibility. The Miranda decision influenced the admissibility of statements in State and Federal courts.

The impact of the case shows the role the courts play in policy-making and specifically in Miranda v. Arizona (1966), in the area of criminal due process and changed the attitudes, behaviors and practices of law enforcement at the local, state and federal levels. The ruling impacts how suspects are treated when arrested. Interrogations are videotaped, cameras are installed on law enforcement vehicles, police officers must carry the Miranda card and suspects are encouraged to remain silent until an attorney is present for questioning.

References:

Davis v. United States, 401 U.S. 222 (1971)

Gideon v. Wainwright, 372 U.S. 335 (1963)

Harris v. New York, 512 U.S. 452 (1994)

Miranda v. Arizona, 384 U.S. 436 (1966)

Supreme Court, United States." The Columbia Encyclopedia, 6th ed.. 2014. Retrieved March 11, 2015 from Encyclopedia.com: http://www.encyclopedia.com/doc/1E1SupremeC.html

Vile, J. R. (2010). Essential Supreme Court decisions: summaries of leading cases in US constitutional law. Rowman \& Littlefield Publishers. 


\section{[Week 3]}

Hi. Elizabeth,

I have enjoyed reading your post. Your view seems that the state or local governments shall be primary to regulate the use and consumption of alcoholic beverage. I agree that such sphere would be on the local custom and community culture rather than the grand scale of uniformity. While the science is one subject of federal government incumbent on its promotion, two governments learn mutually in interaction if the state stands on the specificities of loci. The Supreme Court also recognized as a matter of constitutional theory, the kind of terms and value, such as "independent state grounds." The term would restrict an unleashed preference of federal intervention and complement with the judicial restraint to protect from a grey area of policy making role. This understanding also reinforces our virtue of local or state autonomy. I respectfully have a different view, however, if the Congress acted on the spending power and provisions or funding is associated with the regulation. The drafters of constitution had been discrete on the federal taxation and equality of several states. Their fiscal or budget is coexistent or competing in some cases rather than the uniform or hierarchical administration within the fiscal federalism. The Eighteenth and Twentieth Amendments are a constitutional agreement from the temperance movement in early of $20^{\text {th }}$ centuries. That could have made the US a kind of unique or odd country in which no alcoholic beverage could be traded or consumed. The latter amendment, however, deferred to the state authority that is viewed to normalize the controversy with most of other countries. Since the amendment provided only that the state "can regulate," not to specify "the ways to regulate," the Congress can interact with the state authority on that issue, especially if grounded on other constitutional provisions, for example, spending power. In that case, we may find no good argument on the ground that the intervention is too paternal and infringes with the state sovereignty or autonomy. How do you find an extent of commonality among the states in view of alcoholic consumption? How much had been the intervention effective to reduce the traffic accident or juvenile crimes? Respectfully.

Author: Elizabeth Davis Date: Wednesday, March 18, 2015 3:52:40 PM EDT Subject: RE: Discussion - Week 3

(Against). The Commerce Clause is a power granted to Congress by the U.S. Constitution in Article 1, Section 8, Clause 3 that gives them authority to oversee commerce between the states, foreign nations and Indian tribes. They have been many cases brought before the court in which there has been a disagreement in regards the powers that have granted to Congress by the Commerce Clause. In South Dakota v. Dole (1987), the United States Congress passed the National Minimum Drinking Age Act in 1984, which withheld a portion of federal highway construction funding from states that did not maintain a minimum legal drinking age of 21. South Dakota, which allowed 19-year-olds to purchase beer containing up to $3.2 \%$ alcohol, challenged the law stating that the law exceeded congressional powers under the spending clause (Vile and Menez, 2010).

The questions of this case becomes whether or not Congress violated the Twenty-first Amendment and if they are within their rights regarding spending powers in which they can withhold funds from states who did not require a minimum of 21 years to legally drink. The Supreme Court decided that Congress was not in violation. The Supreme Court 7-2 decision, held that the statute represented a valid use of Congressional authority under the spending 
clause, and that the statute did not infringe upon the rights of the states. I'm against this ruling simply because the Twenty-first Amendment was only ratified by the states to which the U.S. Constitution had previously repealed the Eighteenth Amendment that had established the prohibition of alcohol. According to Vile and Menez (2010), the Twentyfirst Amendment repealing national alcoholic prohibition was done through special conventions in each state being that Article $\mathrm{V}$ did not address a number of important issues such as amending and ratifying amendments. In my opinion the questions that were put before the Supreme Court to considered were ambiguous at best because it left the interpretation of the U.S. Constiution up to them.

\section{References}

South Dakota v. Dole, 483 U.S. 203 (1987).

Vile, J. R., \& Menez, J. F. (2010). Essential Supreme Court decisions: Summaries of leading cases in U.S. constitutional law. Lanham, Md: Rowman \& Littlefield Publishers.

\section{Bronia Ashford}

RE: Discussion - Week 3 (Bronia)

I am for the Supreme Court decision in United States v. Lopez. United States v. Lopez was a case brought to the Supreme Court due to the Commerce Clause. The Commerce Clause and the 1990 Gun Free School Zones Act were used for the court to make its decision. The Gun Free School Zones Act involved "forbidding individuals from knowingly carrying a gun in a school zone" (Oyez, 1994). The Supreme Court decision determined if the Act was "unconstitutional because it exceeded the power of Congress to legislate under the Commerce Clause" (Oyez, 1994). It was also determined "possession of the firearm did not have any concrete tie to interstate commerce" (United States v. Lopez, 1995).

There were several questions regarding the Commerce Clause. The Court made the decision that "the possession of a gun in a local school zone is in no sense an economic activity that might, through repetition elsewhere, have such a substantial effect on interstate commerce" (United States v. Lopez, 1995). The Commerce Clause in relation to United States v. Lopez is described as a "criminal statute that by its terms has nothing to do with "commerce" or any sort of economic enterprise" (United States v. Lopez, 1995).

\section{The court properly ruled in the use of the commerce clause}

When reviewing United States v. Lopez, I was a bit confused as to why this case involved the Commerce Clause. The decision made in the case supported my thoughts. The Justices found "the possession of a gun in a local school zone is not an economic activity that might, have a substantial effect on interstate commerce" (Oyez, 1994). The decision further asserted, "the law is a criminal statute that has nothing to do with "commerce" or any sort of economic activity" (Oyez, 1994).

\section{Expands or contracts the commerce clause}


I believe that the case did not expand or contract the commerce clause. The case did not relate to the commerce clause. In summary, the Court viewed that; "Lopez was simply carrying a gun, not attempting to buy or sell it or to use it to conduct some sort of commercial activity" (Althouse, 1996). Also, "The Gun Free School Zones Act is not an attempt to regulate economic activities at all" (Althouse, 1996), therefore, the case did not expand or contract the commerce clause.

\section{Reference:}

Althouse, A. (1996). Enforcing Federalism After United States v. Lopez. Ariz. L. Rev., 38, 793.

United States v. Lopez, 514 U.S. 549, 115 S. Ct. 1624, 131 L. Ed. 2 d 626 (1995).

United States v. Lopez. The Oyez Project at IIT Chicago Kent College of Law. Retrieved from: http://www.oyez.org/cases/19901999/1994/1994_93_1260.

Hi. Daniel,

Thank you for the good post. While the hotel owner's argument was orthodox on his property right or liberty to operate his business in his own way, the federal intervention had been upheld. The slavery or servitude and equality of civil virtue within the race, gender, ethnicity and other traits, had been an intense theme over the centuries as hinted by the Court. The Statute seems direct and touching by regulating the ways of business operation in this case. In comparison, the Gun Free School Zone Act would not be on the industry or business, but the possessors of gun, which, nonetheless, was struck down. Hotel businesses would never be less of public utility than gun manufacturing or selling. Do you consider the Court would deliberate if the greatest happiness for the greatest number would prejudice the hotel owner and benefit the owners of gun industry? Given many racial minorities and discriminated interstate travelers, the practice of hotel owners had to be regulated? A small number of victims may never rough in number the kind of traffic ones to exonerate the gun businesses? Then how much severity of life interest, in view of civil virtue, do you think to factor than segregation? Do you agree if the segregation issue is such tough to equal the life value? Respectfully?

Author: daniel hallman Date: Wednesday, March 18, 2015 10:10:49 PM EDT Subject: RE: Corrected Reference- Please Use. Discussion - Week 3

\section{Daniel F. Hallman Jr., Discussion Post Week 3.}

\section{Main Question Post:}

Position: For. The case selected for this week's discussion post regarding the commerce clause is Heart of Atlanta Motel v. U.S, 379 U.S. 241 (1964). Furthermore, the commerce clause established within "Article 1, Section 8, Clause 3 of the U.S. Constitution... gives Congress the power 'to regulate commerce with foreign nations, and among the several states, and with the Indian tribes'" (Cornell University Law School, 2015, para. 1). Therefore, within the aforementioned case the commerce clause was properly applied. Hence, the case 
referenced as Heart of Atlanta Motel v. U.S (1964) was a particular case in which a hotel owner was discriminating against African-Americans, and not allowing entry into the owner's establishment, because they were African-Americans. That the hotel owners practice by discriminating against African-Americans was in direct violation of the Civil Rights Act of 1964; however, the hotel owner asserted that the foregoing Act violated his Fifth Amendment, because it "deprived...right to choose its customers and operate its business as it wishes, resulting in a taking of its liberty and property without due process of law and a taking of its property without just compensation" (Heart of Atlanta Motel v. U.S, 1964, p. 244).

Nevertheless, the Supreme Court established that there was a plethora amount of evidence "that discrimination by hotels and motels impedes interstate travel" (Heart of Atlanta Motel v. U.S, 1964, p. 253). Additionally, "a motel which concededly serves interstate travelers is within the power granted it by the Commerce Clause of the Constitution, as interpreted by this Court for 140 years" (Heart of Atlanta Motel v. T.S., 1964, p. 261). Therefore, because the hotel owner within this pertinent case solicited individuals from other states to lodge within the hotel establishment that by utilizing segregation and discriminatory actions against African-Americans was in violation of the Civil Rights Act of 1964 and could be regulated under the commerce clause because the hotel owner was essentially doing business among the states (Heart of Atlanta Motel v. U.S, 1964). Thus, for the foregoing reasons aforementioned I would agree and be "For" or in concurrence with the court that the hotel owner was not deprived of "liberty or property under the Fifth Amendment" (Heart of Atlanta Motel v. U.S, 1964, p. 258). And, allows Congress to regulate commerce between the states when discrimination or segregation are taking place.

Resources

Civil Rights Act of 1964

Cornell University Law School. (2015). Commerce Clause. Retrieved from, http://www.law.cornell.edu/wex/commerce_clause

Heart of Atlanta Motel v. U.S. 379 U.S. 241 (1964)

U.S. Constitution, Article I $\S 8$ 


\section{[Week 4]}

Hi Whitney,

Thank you for the excellent post. The gender-based discrimination seems to center on the equality of workplace. Despite a pluralistic understanding, it is generally regarded that the multiculturalism and workplace democracy can provide a public tranquility. The pregnancy is an important incident not only for woman, but also families of society and economy of nation. Although a stringent and dispassionate fashion of articulation would be the quality of judicial business, the decision may arouse a public discomfort and discontent of woman. Since it is an additional risk and man also has a scope of factors involving a risk in purpose of insurance scheme, the court opinion may be balanced. Most importantly, the court would prefer to defer unless a fundamental breach of civil rights would be identified. Behind this passivity of judiciary, we consider two dimensions if the Chevron rule would govern the public administration and the liberty to economic activities or freedom of contract would be pivoted on this area of concern, say, the civil rights. This structure of awareness would allow the Supreme Court to act as an independent and neutral arbiter. Since my view is pro-court in this case, how do you consider if the Congress had not acted to create the pregnancy disabilities act? At this time, do you expect if the Court would strike down the PDA once any disputed party raises the issue in litigation? Respectfully.

\section{From Whitney}

\section{Civil Rights Decisions and Public Opinion}

\section{General Electric Co. v. Gilbert (1976)}

Suggesting that the insurance plan provided by General Electric violated Title VII of the Civil Rights Act, General Electric Co v Gilbert (1976) was brought before the Supreme Court to challenge the ability of said company to discriminate an employee based upon sex. The insurance plan was all-encompassing, denying no members exclusion due to gender, "but merely remove[d] one physical condition - pregnancy - from the list of compensable disabilities" (FindLaw, 2015, I2). Reversing every appeals court decision held prior, the Supreme Court ruled that employers could legally exclude pregnancy (and pregnancy related conditions) from employee benefit plans since it was not sex discrimination, but merely discrimination between pregnant and non pregnant persons (American Constitution Society, 2015). In delivering the opinion of the Court, Justice Rehnquist explains that "pregnancy-related disabilities constitute an additional risk, unique to women, and the failure to compensate them for this risk does not destroy the presumed parity of the benefits, accruing to men and women alike, which results from the facially evenhanded inclusion of risks." (FindLaw, 2015, $₫$ |32).

Public response was not positive, prompting Congress to quickly pass the Pregnancy Discrimination Act (PDA), an amendment to Title VII of the Civil Rights Act, with specific intentions "to prohibit sex discrimination on the basis of pregnancy" (US Equal Employment Opportunity Commission, 2015, I11). The Act also indicated that pregnant women are to be treated in a similar fashion as other employees, and employers are forbidden from excusing a woman from a job based upon her pregnant state (American Constitution Society, 2015). 
The Supreme Court's decisions do not always coincide with public opinion (Vile, 2010), as was evident in General Electric Co. v. Gilbert (1976). As heralds of the Constitution, Justices are appointed for life with intentions to free them from the influences of political implications and majoritarianism (Reinhardt, 1994). On a positive note, insulation from public opinion allows for Justices to practice what is intended of theminterpretation of the Constitution without over-arching political influence. To follow the law is their job, not to follow the voice of public opinion and/or political influence. Unfortunately, insulation from public affairs also renders the Justices unknown to majority opinions. Though the Constitution serves as the document by which the Supreme Court must abide, times change, culture matures, and policy must - to a degree - follow suit.

\section{References}

American Constitution Society. (2015). General Electric Co. v. Virginia. Retrieved from, https://www.acslaw.org/acsblog/all/general-electric-company-v.-gilbert

FindLaw. (2015). General Electric Co. v. Gilbert, 429 U.S. 125 (1976). Retrieved from, http://caselaw.lp.findlaw.com/scripts/getcase.pl?court=US\&vol=429\&invol=125

General Electric Co. v. Gilbert, 49 U.S. 125 (1976)

Reinhardt, S. R. (1994). The Supreme Court as a partially political institution. Harvard Journal of Law \& Public Policy, 17(1), 148-153.

United States Equal Opportunity Employment Commission. (2015). The pregnancy discrimination act of 1978. Retrieved from,

http://www.eeoc.gov/laws/statutes/pregnancy.cfm

Author: Tina Brooks Date: Thursday, March 26, 2015 9:36:58 PM EDT Subject: RE: Discussion - Week 4: Main Post

Hi. Tina,

Religious Freedom Restoration Act of 1995

I have enjoyed reading your post. The separation of powers principle would be an embedded practice of vast democratic governments nowadays. Given if the Supreme Court viewed other branches would have no authority to define or interpret the Constitution, that would be implausible since they are housed within the terms or phrases of Constitution and played on the field leveled by it. Since they have to exercise the power of copyright, they shall define what the copyright means. Since the President has a duty to appoint the federal officers, he initially interprets the scope of federal office that he can post without the consent of Senate. Along with this line of argument, we may know the kind of controversy if the strong or weak presidency would be compatible with the judicial review. In this case, the constitution, specifically section 5, stated that the Congress shall "enforce," which particularized its role and authority in dealing with the Fourteenth Amendment. Hence man can be special on viewing its role and authority distinct with other normal sphere of interplay. In any case, the "principle of finality" often would create the condition that the judiciary of many nations is distinct in safeguarding the normative power of Constitution, such as in Korea or Japan. The 
section 5 is especially conceived as if the emergency of nation would intend to extract the loyalty of governmental branches, seeing that the Congress turned into mere of implementing agency than creating. President Lincoln argued on a strong presidency to respond with the national challenges, and imposed the Fourteenth Amendment. However, his federalism paradoxically would be limited by the commanding sense of terms "enforce." Otherwise, we may experience an increased role of Congress in nationalizing the ethos of civil rights. In the condition of nation or current sense of federalism, how do you find plausible the Congress shall be limited in the judicial purview? Respectfully.

Tina Angela Brooks

\section{Religious Freedom Restoration Act of 1995}

\section{City of Boerne v. Flores (1997)}

The petitioners challenge the constitutionality of the Religious Freedom Restoration Act of 1995 after being denied a building permit. The Supreme Court ruled that Act to be unconstitutional because it contradicted the separation of power as defined by the Constitution. The Court decided that the proper exercise of congressional authority under Section 5 is to enforce the provisions of the fourteenth amendment. The Supreme Court determined 6 to 3 that the Act did not attempt to enforce the Amendment but interpret and redefine its terms. The Court decided that the Act infringed on the rights and interests of State and local government and determined that Section 5 of the Fourteenth Amendment granted Congress remedial power to the extent of enforcement of the Amendment's provision, not unlimited power. The case limited the power of the federal government in matters that are inherently state and local interests. It also limits Congresses interpretive powers concerning the Constitution retaining the ultimate power to interpret the Constitution with the judicial branch. The Supreme Court justices share a luxury of being able to protect its powers from being usurped by the other branches of government while limiting their powers through Constitutional interpretation. On the other hand, the Court's decisions are only upheld as long as there are a majority of justices that share the same view of the previous court concerning that issue. Meaning that although it may be interpreted by todays Supreme Court to be unconstitutional the next generation of Supreme Court justices may disagree and reverse that decision.

City of Boerne v. Flores 521 U.S. 507 (1997)

References

Religious Freedom Restoration Act of 1993, 42 U.S.C.S. §2000bb et seq.

\section{Hi. Precious,}

I have enjoyed reading your post. The public education fairly is a sensitive issue in concerns, i.e., the student performance, socialization as well as social stratification and congruent society on democracy. It would be one of second generation rights in the framework of UN that the nation shall be affirmative to provide a minimum of public education. Given the sense of inferiority affects a motivation of student to learn, segregation but equal may have no place. However, as it seems if the sanction of law would aggravate a worse nature of public policy, how do you note if desegregation should not be any absolute standard as impermissible of any secondary measure to respond with the local circumstances? Do you 
expect if the educational policy makers would always be conservative for his merits or against a possible disadvantage of career building? Respectfully.

\section{Precious Clayton}

RE: Discussion - Week 4

Post a brief description of the case you selected. Then explain how the case did or might influence federal, state, and/or local public policies. Be specific and use examples to illustrate your explanation. Finally, with the case you selected in mind, explain at least one pro and one con of Supreme Court justices being insulated from public opinion. Be specific.

\section{Case}

The case I selected was the Brown vs. Board of education was a case that the district court found that the facilities provided for black elementary school students in Topeka were largely equal to those provided to white students. Reasoning that it was required to follow U.S. Supreme Court precedents validating "separate but equal," the court ruled in favor of the school board. However, attached to the court's decision was a finding of fact that "segregation of white and colored children in public schools has a detrimental effect upon the colored children," and that "the impact is greater when it has the sanction of law." The case was appealed to the U.S. Supreme Court and consolidated with cases from Delaware, Virginia, South Carolina and the District of Columbia, all under the name of Brown v. Board of Education. Several reasons have been given for the placement of Brown as the first case. One, Mr. Brown was a minister and his wife a teacher, both respected members of their communities. Also, by using a non-southern state as the flagship case, lawyers could show that segregation was a national issue. Last, and perhaps most important, the relatively equal status of schools in Topeka would focus attention on destroying, rather than enforcing, the "separate but equal" doctrine.

On May 17th, 1954, the Supreme Court unanimously ruled in favor of the plaintiffs, holding that: "Segregation of white and colored children in public schools has a detrimental effect upon the colored children. The impact is greater when it has the sanction of the law, for the policy of separating the races is usually interpreted as denoting the inferiority of the Negro group. A sense of inferiority affects the motivation of a child to learn. Segregation with the sanction of law, therefore, has a tendency to [retard] the educational and mental development of Negro children and to deprive them of some of the benefits they would receive in a racially integrated school system... We conclude that, in the field of public education, the doctrine of "separate but equal" has no place. Separate educational facilities are inherently unequal."

One Pro of the Supreme Court justices being insulated from public opinion would be for this case, it may cause the judges to focus more on the facts of the case, the constitution and civil rights as not to public opinion and what is going to make everyone else happy but what is going to be in the best interest of the people. A con of Supreme Court justices would be that once a decision had been reached that there will not be able to appeal to higher court beyond the Supreme Court without their being a constitutional amendment.

\section{Reference Page}

Brown v. Board of Education. (2015). Retrieved from 
http://www.civilrights.org/education/brown/brown.html 


\title{
[Week 5]
}

\author{
Hi. Sheron,
}

Thank you for the informative post. The story from Indiana has also been edited to reach the Korean audience in exotic feels of diversity or multiculturalism in the US Society. Korea has no such laws to deal with the area restricting the freedom of contract, except for general considerations of economic justice, e.g., unconscionability or yellow dog contract. The freedom of contract, as one Justice of US commented, has no place explicitly within the Articles or Amendments of Constitution. Merely termed with the life, liberty and equal protection of law, the fourteenth amendment and act of civil liberty regulates the state government and, interestingly, contractual relationship between the private citizens. The Contract Clause in the main text of Constitution also generally is viewed irrelevant to intervene with the private relationship, rather limited to impose the duty of governments not to abridge the existing privileges or rights arising from the contract with government, perhaps expanded least possibly on that between the private parties. Hence, the original frame on freedom of contract, often prevailed in the thought of enlightenment and pronounced to characterize an important transformation from the feudal to modern liberal state by Maine, generally remains ambiguous if it would be mere of one strand within the natural law. No positive ground on its legal effect could unlikely be ascertainable at least in the statutory ground that the legal positivists could not dose unlike the quasi-constitution of Civil Code in earlier France, one of five Napoleonic codes. The context implies that Korean restaurants may have more legal basis exercising to accept or reject his patrons. The recent issue would be thought if (i) the Act of Civil Rights is an inversed approach showing the power and influence of social and cultural elements within the community, yet to be competed among another involving a differing civil right, such as gay right or right to privacy and religious freedom (ii) most of nations would generally have a cause on the economic justice provided if the regulators plan to engage in the issue of freedom of contract, in which they may learn to restore the social justice by employing the kind of US perspectives (iii) the state size, in America, is often viewed most adequate in shaping a best public policy that the deference paradigm of federal government could speak (iv) the establishment clause, disestablishment in effect on one hand and dubious, on the other, if extended to the state government other than federal one, generally comes in conflict with the free exercise of religion, which entangles with the purpose of Civil Rights Act in complications. How do you assess, as a matter of state policy, these two states had put a high emphasis on the religious right? Do you identify any other laws or similar attempts from other states? Respectfully.

Author: Sheron Hendrix Date: Friday, April 3, 2015 2:16:53 PM EDT Subject: RE: Discussion - Week 5

\section{First Amendment Freedoms}

The First Amendment is one of the most revered and important provisions of the U.S. Constitution because it has a number of guarantees which include provisions for religious freedom, freedom of speech and of the press, peaceable assembly, and freedom to petition ( $\mathrm{p}$. 207). The two provision of the First Amendment that deals with religion are the establishment clause, and the free exercise clause; clearly, the "establishment of religion" clause prohibits Congress from adopting laws of a national church (p. 207). However, the 
Supreme Court has struck down most religious exercises in public schools such as prayer, Bible reading, and other devotional exercises as a violation of the establishment clause, making makes nonbeliever appear to be outsiders. Prayer, Bible reading, and other vocal devotional exercises are all forms of free speech, so why aren't these rights protected under the Free Speech clause?

Today, in LITTLE ROCK Ark., Lawmakers in Arkansas and Indiana passed legislation Thursday that they hoped would quiet the national uproar over new religious objections laws that opponents say are designed to offer a legal defense for anti-gay discrimination (DeMILLO \& DAVIES, 2015). The Indiana amendment prohibits service providers from using the law as a legal defense for refusing to provide goods, services, facilities or accommodations; baring discrimination based on race, color, religion, ancestry, age, national origin, disability, sex, sexual orientation, gender identity or U.S. military service (DeMILLO \& DAVIES, 2015). However, the measure exempts churches and affiliated schools, along with nonprofit religious organizations (DeMILLO \& DAVIES, 2015).

In my opinion, I think Arkansas and Indiana Lawmakers are on the right path to getting on the right path to religious freedom. While gay marriages have become legal in a number of states, if a Bishop, Reverend, Preacher, or Pastor refused to perform a gay ceremony because it violates his religious beliefs, it is not a case of discrimination, just a case of his convictions.

Never the less, the Free Speech clause has its limitations; specifically, these limitations are as followed:

Not to incite actions that would harm others (e.g., "[S]hout[ing] 'fire' in a crowded theater."), Schenck v. United States, 249 U.S. 47 (1919).

Not to make or distribute obscene materials, Roth v. United States, 354 U.S. 476 (1957).

Not to burn draft cards as an anti-war protest, United States v. O'Brien, 391 U.S. 367 (1968).

Not to permit students to print articles in a school newspaper over the objections of the school administration, Hazelwood School District v. Kuhlmeier, 484 U.S. 260 (1988).

Students not to make an obscene speech at a school-sponsored event, Bethel School District \#43 v. Fraser, 478 U.S. 675 (1986).

Students not to advocate illegal drug use at a school-sponsored event, Morse v. Frederick, U.S. (2007).

This should include the internet, however, the Court has yet to make the final say in the matter.

References:

DeMILLO, A. \& DAVIES, T. (2015, April, 1) Retrieved from http://www.msn.com/enus/news/politics/indiana-arkansas-pass-revised-religious-objection-proposals/arAAakIbu?ocid=ansnewsap11 
U.S. Courts. Retrieved from: http://www.uscourts.gov/educational-resources/getinvolved/constitution-activities/first-amendment/free-speech.aspx

Vile, J.R. (2010). Essential Supreme Court Decisions: Summaries of leading cases in U.S. Constitutional law. (5th ed.) Lanham, Md: Rowman \& Littlefield Publishers.

Hi. Emmanuel,

I have enjoyed reading your post. It might be a mystery that such social tone, odd on white supremacy, had prevailed once in America and to see if Brandenburg is perhaps any remotest or deep inland from Africa in geography of Europe. The reality of Ohio state would, however, be serious and challenging from his eloquence or incitement as disintegrative or callous with neighbors. A differing conclusion from two tiers of Court likely implies between the public policy and law. The federal judiciary would be a last resort to the haven of law where the state must be a vanguard to public safety and integrative community. Although we are grateful to learn both of law and public policy, how much are you empirically convinced if mere incitement could not lead to imminent lawless action? Do you consider if the traditional Actus Reus requirement may go weaker or as same within the e-communication age? Respectfully.

Author: Emmanuel Nwosu Date: Thursday, April 2, 2015 5:08:25 PM EDT Subject: RE: Discussion - Week 5

\section{Freedom of Speech}

\section{Main Discussion Post}

\section{Policy or Controvsery Identified: Ohio Criminal Syndicated Statute- Rev. Code Ann section 2923.13}

Brandenburg the leader of a white supremacy group Ku Klux Klan gave a speech at a rally and it was later broadcast first on local televion thereafter on national television network. The Ohio state government charged him to court for which he was convicted under the Criminal Syndicated Statute for advocating, necessity, or propriety of crime, sabotage, violence or unlawful method of terrorism-Ohio Criminal Syndicated Statute Rev. Code Ann 2923.13. He challenged the constitutionality of the statute under the First and Fourteenth Amendments to the intermediate appellant court and the court upheld the conviction without an opinion, while the Ohio state supreme court dismissed the appeal "sua sponte for the reason that no substantial constitutional question exist herein", it never gave any opinion or expain its conslusions".

Such statutes as those of Ohio and other states have the tendency to in frige on individual free speech. My thought of how the matter could be settled was in agreement with how the U. S. Supreme Court eventually settled the case or controversy. In doing so it reasoned that since the Ohio statute did not distinguish between "mere advocacy" with criminal incitement which may result in "imminent lawlesness" such law violate the petitioner's freedom of speech. The Supreme Court stated that "the constitution gurantees free speech and free press do not permit state to forbid or proscribe advocacy of the use of force or of law violation except where such advocacy is directed to inciting or producing imminent lawless action and is likely to incite or 
produce such action-see Noto v. United States,367 U. S. 290,297, 298 (1961 or in Herdon v. Lowry, 301 U. S. 242,259-261 (1937; Bond v. Floyd, 385 U. S. 116, 134 (1966). A statute which "fails to draw this distinction impermissibly intrudes upon the freedoms guaranteed by the First and Fourteenth Amendments. In the instant case, there was no iota of evidence that Brandenburg was advocating violence or incite his group that may result in immenent lawlessness. Because the Ohio state statute did not distinguish "mere advocacy" from incitement to imminent lawless action the Supreme Court reversed the conviction.

In concurring, Justice Holmes stated that "every idea is an incitement" and "eloquence may set fire to reason", but "the redundant discourse before us had no chance of starting a present conflagration".

Reference

LexisNexis Academic lexisnexis.com.ezp.waldenulibrary

395 U. S. 444; 89 S. Ct. 1827; 23L. Ed.430; 1969

Hi. Annie,

Thank you for the informative post. On the religious freedom restoration act, the same purpose had been respected by over twenty states, including Indiana days ago. Although the principle of "congruence and proportionality" guided by the Supreme Court had led to the invalidation of that federal act as applied to the states, the Act still has an effect to the federal government, e.g, Gonzales v. O Centro Espirita Beneficente Uniao do Vegetal, perhaps in the scope if contradiction may be saved from the rulings of Supreme Court. The Supreme Court developed a strict scrutiny to be used in examining free exercise of religion, but struck down the statute, which is generally seldom when it decided to apply such standard of examination. It is often more receptive that the classic liberty is meant negative and as free from the public intervention. The Act is facially promotional as it nuances in its title, which may stimulate a disposition of justices to suspect its constitutional validity. We may argue on a positive state to promote a general welfare of nation or enhanced institution and state intervention for the personal freedom or classic liberty. The negative or classic liberty may exist in parallel, but I suppose if it would still be incongruent between the establishment of modern prison system or updated technology of metal detectors and expansion of missionary buildings. Given the Catholic or religious denominations would not be uncommon nationwide, it may not be striking to turn on congruence and proportionality if the Congress has defined a protectable scope of religions or endeavor on any due draftsmanship. Nevertheless, we would still incompletely be settled if the nation and church shall separate and Constitution emancipated, far from intending to promote, the subjects of religious institution. Though it depends on the national contingencies, the protection of citizen from potential criminal activities perhaps would not be equivalent of that of religious group. While the Congress uses a "restoration" other than promotion or protection, the substance would not be unlike that may potentially infringes with equal protection of laws between the religious group and nonbelievers with distinct privacy. How much do you sense a religious diversity or different policy environment across state jurisdictions disallowing the intervention of Congress? Respectfully. 
Author: Annie Scott-Douglas Date: Friday, April 3, 2015 12:21:28 AM EDT Subject: RE: Discussion - Week 5 (Scott-Douglas)

Freedom of Speech

The First Amendment is a fundamental right, however, the exception to the First Amendment is that social media sites have a responsibility to establish programs, policies and procedures that prevent threats, defamation and bad speech. Freedom of Speech is a fundamental part of the democratic society (Vile, 2010).

In City of Boerne v. Flores, Archbishop of San Antonio and the United States 521 U.S. 507 (1997), the Supreme Court decided in favor of the City of Boerne. Congress relied on its enforcement power of the Fourteenth Amendment (Cornell, n.d.). The question in the case was whether Congress exceeded its Fourteenth Amendment powers by enacting the 1993 Religious Freedom Restoration Act. The Court concluded that evidence did not suggest the City of Boerne favored one religion over another (Oyex, n.d) and that Congress exceeded its power by enacting the Religious Freedom Restoration Act (Cornell, n.d.).

Although Brandenburg's speech was aimed at inciting violence, the Court ruled in Brandenburg v. Ohio 359 U.S. 444 (1969) that Ohio's Criminal Syndication Law violated Brandenburg's right to freedom of speech (359 U.S. 444, 1969). According to the Court, the law was too broad and did not address whether the teaching of violence would resort to violence (359 U.S. 444, 1969).

The Founders did not address social media in the writing of the First Amendment, therefore, the Court has expanded its role in interpreting the constitutionality of social media. In 1996, Reno v. ACLU (American Civil Liberties Union), 521 U.S. 844 (1997), the Supreme Court expanded its role and extended the First Amendment to include written, visual, and spoken expression on the internet (521 U.S. 844, 1997). The Court ruled in favor of ACLU and decided that the 1996 Communications Decency Act violated the First and Fifth Amendments (1997). Although the act was established to protect underage children from obscene and indecent internet material, the Court determined that the act was broad and vague (1997).

With the advent of twitter, Facebook, and LinkedIn, corporations have a responsibility to censor social media sites and hold employees accountable. However, the role of the Supreme Court in deciding the constitutionality of the possible scenarios of free speech on social media is expected to grow and expand the contents of the First Amendment. Although the First Amendment gives people the freedom of speech, the Supreme Court and sometimes search engines are left to decide what speech is appropriate for social media and what speech must be deleted or suppressed.

References

Brandenburg v. Ohio 395 U.S. 444 (1969).

City of Boerne v. Flores 521 U.S. 507 (1997). Retrieved from https://www.law.cornell.edu/supct/html/95-2074.ZS.html 
City of Boerne V. Flores 521 U.S. 507 (1997).

Reno v. ACLU 521 U.S. 844 (1997). Retrieved from http://www.oyez.org/cases/19901999/1996/1996_96_511

Supreme Court, United States." The Columbia Encyclopedia, 6th ed.. 2014. Retrieved March 11, 2015 from Encyclopedia.com: http://www.encyclopedia.com/doc/1E1SupremeC.html

Vile, J. R. (2010). Essential Supreme Court decisions: summaries of leading cases in US constitutional law. Rowman \& Littlefield Publishers 


\section{[Week 6]}

Hi. Daniel,

Thank you for the informative post. The civil action raised by a group of Nigerian nationals seems to seek a basis of claim from decayed incidents? We, Koreans, also have a claim on comfort woman or war crimes of inhumanity against Japanese government. It is encouraging that the US had shared a same ethos on the issue of Alien torts with the nations of world. That seemed to come positive on the part of US because the issue or involvement can be more normative or practicable than other types of foreign affairs, perhaps the topic of this week. Some issues or subject matters would likely be delicate or over-inclusive as well as less substantial or against the traditional notion of sovereignty in terms of international law theory, which would make the US reluctant to sign or ratify. Tokyo protocol on the environmental protection, laws of sea, and treaty of international criminal court might fall within that category. Since the judiciary would, in most tendency, dispose the issue on a normative basis, the technicality of law would operate that could be received against the ethical view or sensibility of public. How do you assess the quality of action in terms of historical thought or political consideration? Or in terms of statute of limitations? Often Japanese and US government suggest that the event is merely historical passed long ago and considered to some end. Do you think if the kind of legal idea, for instance, statute of limitations, could guide not only jurists, but also public? Respectfully.

Author: daniel hallman Date: Wednesday, April 8, 2015 12:07:35 AM EDT Subject: RE: Discussion 1 - Week 6

\section{Daniel F Hallman Jr., Discussion Post Week 6.}

\section{Main Discussion Question.}

A recent Supreme Court example as to the lack of constraint on federal government vis-à-vis foreign policy is the case, known as Kiobel et al., v. Royal Dutch Petroleum Co. et al., (2013). Furthermore, "a group of Nigerian nationals residing in the United States, filed suit in federal court against certain Dutch, British, and Nigerian corporations. Petitioners sued under the Alien Tort Statute, 28 U.S.C. $§ 1350$. The petitioners alleged that while they were residents within the area of Nigeria the "Royal Dutch Petroleum Company and Shell Transport and Trading Company, p.l.c., were holding companies incorporated in the Netherlands and England." (Kiobel et al., v. Royal Dutch Petroleum Co. et al, 2013 p. 1662), as well as in Nigeria and allowed the aforementioned companies and subsidiaries "to enlist[] the Nigerian government to violently suppress... demonstrators" (Kiobel et al., v. Royal Dutch Petroleum Co. et al, 2013, p. 1662). Additionally, the alleged suppression of demonstrators by and through the Nigerian government, working in tandem with the aforementioned companies asserted that "throughout the early $1900 \mathrm{~s}, \ldots$ Nigerian military and police forces attacked Ogoni villages, beating, raping, killing, and arresting residents and destroying or looting property" (Kiobel et al., v. Royal Dutch Petroleum Co. et al, 2013, p. 1662). That now the petitioners, having been granted political asylum are legal residents within the United States (Kiobel et al., v. Royal Dutch Petroleum Co. et al, 2013).

The Alien Tort Statute, 28 U.S.C. $§ 1350$ (ATS) established that "district courts shall have original jurisdiction of any civil action by an alien for a tort only, committed in violation 
of the law of nations of treaty of the United States" (Kiobel et al., v. Royal Dutch Petroleum Co. et al, 2013, p. 1662). However, the Supreme Court affirmed the lower court's holding with an elucidation that stated, "Corporations are often present in many countries, and it would reach too far to say that mere corporate presence suffices. If Congress were to determine otherwise, a statute more specific than the ATS would be required" (Kiobel et al., $v$. Royal Dutch Petroleum Co. et al, 2013, p. 1669). Moreover, that the Supreme Court also posited within their holding that the ATS ostensibly was not passed to position the United States as an international enforcer within the world (Kiobel et al., v. Royal Dutch Petroleum Co. et al, 2013). According to Ko and Yoo (2013) what makes this particular ruling significant is "that it provides a wise example of judicial restraint and deference to the role of Congress and the President to set American foreign policy" (para. 1). Therefore, this is a prime example as to when the Supreme Court utilized constraint on foreign policy; thus, granting deference to the President and Congress.

Consequently, that the aforementioned opinion by the Supreme Court will have a major impact on foreign-policy. According to Ko and Yoo (2013) the Supreme Court ruling is "being portrayed as a victory for big corporations over human rights victims. While the decision will allow some multinational corporations to avoid being sued in the United States for business activities overseas." (para. 1). Thus, this could ultimately allow corporations to enlist national governments to utilize horrific measures against those who may protest a company within a foreign nation. Hence, allowing human right violations against those who do not support or protest a company for their business practices. It should also be mentioned, "all nine justices agreed that the ATS should not be interpreted to allow for universal jurisdiction" (Ko \& Yoo, 2013, para. 11). Lastly, this Supreme Court opinion ended 30 years "into international lawmaking by leaving the decision of whether and how to enforce foreign policy to Congress and the President" (Ko \& Yoo, 2013, para. 11).

\section{Resources}

Alien Tort Statute, 28 U.S.C. $§ 1350$

Kiobel et al., v. Royal Dutch Petroleum Co. et al., 133 S. Ct. 1659 (2013).

Ko, J. and Yoo, J. (2013). The Supreme Court Unanimously Rejects Universal Jurisdiction. Retrieved from, http://www.forbes.com/sites/realspin/2013/04/21/the-supremecourt-unanimously-rejects-universal-jurisdiction/

Hi. Tragee.

Thank you for the informative post. You raised two important points in my view. First, the necessary and proper clause would play a role to expand the scope of congressional power, but as confined to the internal matters only. Second, the treaty is the basis of legislation that possibly could intrude the area of state jurisdiction. I found the first rule as reasonable since the constitutional history supports that interpretation or viewpoint. However, the second point seems controversial and that the federalism spelled out expressly within the Constitution should not be violated even if both branches collaborate in any ultimatum to conclude the treaty into a national law. Your thought? Respectfully. 
Author: TRACEE GOODMAN Date: Wednesday, April 8, 2015 10:34:13 AM EDT

Subject: RE: Discussion 1 - Week 6

\section{The Supreme Courts Role in Foreign Policy}

In United States v. Curtiss-Wright Export Corp., 299 U.S. 304 (1936), Justice Southerland stated "The ["powers of the federal government in respect of foreign or external affairs and those in respect of domestic or internal affairs"] are different, both in respect of their origin and their nature. The broad statement that the federal government can exercise no powers except those specifically enumerated in the Constitution, and such implied powers as are necessary and proper to carry into effect the enumerated powers, is categorically true only in respect of our internal affairs." His remarks in this matter express the limited authority of the Supreme Court in matters of foreign policy. Specifically, the US Constitution gives much of the foreign policy decision-making to the President, the Senate has a role in ratifying treaties, and the Supreme Court interprets treaties when cases are presented in relation to a treaty. Further, the Supreme only has jurisdiction over cases involving admiralty and maritime law, and ambassadors and other public ministers (Herring, 2008). It is charged with deciding disputes between states and foreign states and their citizens and subjects.

\section{The Supreme Court's Authority to Interpret Treaties}

Foreign policy determines how America conducts relations with other countries; it is designed to further certain goals. It seeks to assure America's security and defense. To communicate or "deal" with foreign powers, pursuant to the Treaty Clause of the Constitution, the President makes a treaty with foreign powers. The proposed treaty must be ratified by a two-thirds vote by Senate (Herring, 2008). When cases that bring a treaty into question are brought before the Supreme Court, the court has the responsibility to interpret the treaty and apply it to the matter. In Missouri v. Holland, 252 U.S. 416 (1920), the Supreme Court held that the authority to make treaties under the U.S. Constitution is separate from the other specified powers of the federal government. In essence, this ruling provided that the federal government has the authority to use treaties to legislate in areas which would otherwise fall within the exclusive authority of the states.

\section{References}

Herring, G. (2008) From Colony to Superpower: U.S. Foreign Relations Since 1776

Missouri v. Holland, 252 U.S. 416 (1920)

United States v. Curtiss-Wright, 299 U.S. 304 (1936).

Hi. Whitney,

Thank you for the informative post. I may suppose if it merely would be nuanced between a religion and state. While the Christianity may be more powerful or honorable, what do you sense motivated the petitioner to prefer Israel than Jerusalem? How do you consider if the statehood of Israel, perhaps against PLO, would impact the interest of US? Do you see if the context is same with the Curtis-Wright Export Group? We may distinguish, however, if the latter involves a war situation in armed conflict with US. The peacekeeping operation or 
indirect impact on the national defense would not suffice that the Congress should respect a discretion and policy making of President. A recognition of statehood for foreign countries would be one kind of inherent powers vested within President, which is now being contested. In Korea, the issue would not be questioned since the Congress generally is viewed a power of creation unless the Constitution expressly assigns the duty to any specific office. In other words, there do we not find any contrary language that President should do this in Korea. That is perhaps same at US, but the notion and basic sensibility seem strong that the federal congress is not the body of creation, but only one peer with other two branches (most orthodoxy of separation of powers principle) and further, as limited with the federal quality of government. How do you assess the basis of congressional power in your case, and what do you think it any powerful of inherent powers? Respectfully.

Author: Whitney Root Date: Wednesday, April 8, 2015 12:01:41 PM EDT Subject: Main Post Discussion 1 - Week 6

\section{Week Six, Discussion One:}

\section{The Supreme Court and Constraints on Federal Government}

While researching cases for this discussion I came upon an issue that, though yet to be decided by the Court, will certainly have strong implications no matter what the decision may be. The case of Zivotofsky v. Kerry, currently being heard in the Court, questions whether Congress or the President should be tasked with making "day-by-day foreign-policy decisions" (Epps, 2014, \16).

Citing Section 214(d) of the Foreign Relations Authorization Act (2003), which states that "for purposes of the registration of birth, certification of nationality, or issuance of a passport of a United States citizen born in the city of Jerusalem, the Secretary shall, upon the request of the citizen or the citizen's legal guardian, record the place of birth as Israel" (US Government Printing Office, 2003, Section 214(d)), Zivotofsky is petitioning to have his passport read 'Israel' as his place of birth (rather than Jerusalem). The question that the Court must consider is whether the federal statute directing the Secretary of State to record the birthplace as 'Israel' "impermissibly infringe[s] on the President's power to recognize foreign states" (Oyez, 2015, ๆ2).

Should the Supreme Court rule in favor of the United States or in favor of Zivotofsky, the decision will certainly have a large impact on foreign policy as it relates to the President and his power and credibility in foreign nations. As suggested by Epps (2014), "a small decision in this area, if not written clearly, can have outsize influence on unforeseen events" (II15). A decision in favor of the United States will affirm that foreign policy will remain in the hands of the executive branch (President) and that Congress cannot overstep the boundaries as set in the Constitution. A decision in favor of Zivotofsky could have negative effects on the President's credibility in foreign nations, most notably those in the Middle East.

Considering United States v. Curtis-Wright Export Corp (1936), in which it was ruled that, despite no official declaration in the Constitution, the President of the United States serves as the official representative to foreign nations and should be given broad discretionabove Congress - when considering issues of a foreign respect, the influence this holding has 
had since is broad. Being cited in cases involving foreign policy on many levels - from restricting travel and/or exports, to justifying actions of the National Security Agency in fighting terrorism-United States v. Curtis-Wright Export Corp (1936) set the grounds for Presidential power in terms of foreign affairs, resulting in actions that may or may not be acceptable to the general public. The outcome of Zivotofsky v. Kerry will likely have ramifications in other ways.

\section{References}

Epps, G. (2014). Who controls foreign policy: the President or Congress? Retrieved from, http://www.theatlantic.com/politics/archive/2014/10/who-controls-foreign-policythe-president-or-congress/382181/

Oyez.org. (2015). Zivitofsky v. Kerry. Retrieved from, http://www.oyez.org/cases/20102019/2014/2014_13_628

U.S. Government Printing Office. (2003). Foreign Relations Authorization Act. Retrieved from, http://www.gpo.gov/fdsys/pkg/PLAW-107publ228/html/PLAW107publ228.htm

United States v. Curtiss-Wright Export Corp., 299 U.S. 304 (1936)

Zivotofsky v. Kerry

Hi Precious,

I have enjoyed reading your post. I have generally agreed on your point, especially if the issues or policy area entails a normative question. I respectfully disagree if the Supreme Court could be plenary and unlimited since it is given judicial power over "disputes between the States, Citizens and foreign States." For instance, the state action theory in the realm of international law stepped to respect the decision of foreign states. The sovereign immunity act would exclude the foreign states from the jurisdiction of Supreme Court unless the activities are commercial and on some conditions. Hence, those provisions might not be an absolute indication that the Constitution expects the Supreme Court to play an active role of foreign policy making. In my view, that is basically because it is judicially supreme within the national court system. In earlier years, the Paris treaty about civil damages from war destruction or deprivation had been disputed, and the alien torts claim also had a basis of statute. The commercial activities of foreign states could be argued in the national court. However, all these disputes vastly are of legal question subject to the stringency of common law technicalities, which also could be related with the special claims court instituted to remedy the loss of US citizen from the Iranian revolution around 1970's. I consider that the due prejudice or strategic approach required of foreign policy making should recede in these cases, but the legal theory must come in the first priority. Your thought? Respectfully.

Author: Precious Clayton Date: Friday, April 10, 2015 12:26:29 AM EDT Subject: RE: Discussion 2 - Week 6 
Post an argument for or against the Supreme Court's involvement in foreign policy. Justify your argument with academic resources. Then explain at least two implications of the Supreme Court's involvement or lack of involvement in foreign policy. Be specific

In my argument I would be for the supreme courts involvement in foreign policy. Foreign policy determines how America conducts relations with other countries (WIL, 2015). It is designed to further certain goals. It seeks to assure America's security and defense (WIL, 2015). It seeks the power to protect and project America's national interests around the world. National interest shapes foreign policy and covers a wide range of political, economic, military, ideological, and humanitarian concerns (WIL, 2015). The Supreme Court plays a limited role in foreign policy. It has jurisdiction over cases involving treaties, admiralty and maritime law, and ambassadors and other public ministers (WIL, 2015). It also is charged with deciding disputes between states and foreign states and their citizens and subjects.

It is clear that, for two centuries, the courts have played an important role in resolving foreign policy disputes between the executive and legislative branches (JPP, 2015). But this is only one of the two principle divisions of power established by the Constitution. The other principle is dividing power between the states and federal government (JPP, 2015). Along this division, too, the courts have been required to resolve disputes over foreign policy powers (JPP, 2015). The Constitution empowers the United States Supreme Court with the authority to hear and decide all cases and interpret, enforce and void challenged statutes (Lavinbuk, 2015). The Court is given judicial power over treaties made and disputes between the States, Citizens and foreign States (Lavinbuk, 2005).

Reference page

Judiciary Power and Practice. (2015). the courts and foreign policy. Retrieved from: http://www.americanforeignrelations.com/E-N/Judiciary-Power-and-Practice-Thecourts-and-foreign-policy.html\#ixzz3WsPyPrpJ

Lavinbuk, A. N. (2005). Rethinking early judicial involvement in foreign affairs: An empirical study of the Supreme Court's docket. The Yale Law Journal, 114(4), 855903

War and International Law. (2015). Retrieved from http://www.crf-usa.org/war-in-

Iraq/foreign-policy.html

Hi. Tina,

I have enjoyed reading your post. I consider that the reality of international politics or economy is one source of stimulus to develop a legal culture and institutions. I agree if you implied the earlier Court had been more disposed to protect the national interest. A judicial aftermath upon the conclusion of Paris treaty in the independence years had surged that the Courts might be a forum to restore the justice of war, perhaps nationals- protective. The antidumping laws in Canada and US were alleged to be invented in response with the depredatory and lower pricing strategy of Britain, then most advanced industrial state. 
Despite its economic persuasion against consumer welfare, it is now accepted as one of pivotal laws in WTO and nations. In my thought, the foreign policy making, perhaps stranded of strategies and usually associated with the law, is inevitable and co-exists with other dimension of normative control by the Supreme Court. Since strategies without the basis of law is extremely rare, I expect that the normative basis of foreign policy could be controlled by it. And the doctrine of political question would be one prominent judicial invention to clarify and guide the muddied questions of judicial scope. You are precise if the ripeness or separation of powers principle shall restrict the court involvement. I think otherwise if the foreign policies often are associated with the law, and rarely without the normative basis. Your opinion? Respectfully.

Author: Tina Brooks Date: Thursday, April 9, 2015 9:59:19 PM EDT Subject: RE: Discussion 2 - Week 6: Main Post

$$
\begin{gathered}
\text { Foreign Policy and the Supreme Court } \\
\text { Tina Angela Brooks }
\end{gathered}
$$

\section{Foreign Policy and The Supreme Court}

\section{Argument For}

The Constitution empowers the United States Supreme Court with the authority to hear and decide all cases and interpret, enforce and void challenged statutes. Article III of the Constitutions does not limit the Supreme Court's authority to only domestic cases. The Constitution does not give the Supreme Court the power to enact or create treaties. It does however bestows the Court with judicial power over treaties made and disputes between the States, Citizens and foreign States. My opinion is that the Supreme Court does have limited involvement in foreign policy in accordance with the Constitution of the United States and the Court's interpretation of its limitations in Goldwater v. Carter (1979). In Supreme Court cases dated as far back 17 and 1800s, the Court has exercised its judicial powers in foreign policy (Lavinbuk, 2005).

\section{Court Involvement}

The United States Supreme Court decided upon the appeal in from District Court in the criminal case of the United States v. Curtiss-Wright (1936). The Prosecution appealed the lower court's decision to honor the objection of the defendants concerning arms sells to Bolivia. The Court under the authority granted it by Article III of the United States Constitution reversed the decision of the lower court because Congress had authorized the President to declare the sale of arms to certain countries illegal. Bolivia was initially included in the list of countries for which arms sales were illegal, later the President revoked his proclamation. The Defendant's objected to the President's authority. The Court interpreted the Constitution to have vested in the President the power to make decisions concerning international affairs (United States v. Curtiss-Wright 1936). The Court acted in its judicial capacity to interpret the division of power under the Constitution in relationship to foreign policy.

The United States Supreme Court did not get involved in Goldwater v. Carter because the issue was not judicially challenged by the legislative branch or the executive branch. While the justices did render their opinions in a nature met to benefit both branches 
with advice from different angles (Goldwater v. Carter, 1979). The Court interpreted the Constitution as bestowing the authority for the creation of foreign policy on the Executive and Legislative branches.

\section{References}

Goldwater v. Carter 444 U.S. 996 (1979)

Lavinbuk, A. N. (2005). Rethinking early judicial involvement in foreign affairs: An empirical study of the Supreme Court docket, 114(4), 855-904. Retrieved from http://papers.ssrn.com/sol3/papers.cfm?abstract_id=887177

United States v. Curtiss-Wright 299 U.S. 304 (1936)

\section{Hi CHINWE,}

Thank you for the informative post. I agree that the court tends to ensure a balance and neutrality between two branches unless the Constitution clearly dictates otherwise. That seems to be accorded with the original intention of civil theorists on separation of powers principle. The foreign relations can have two major traits, say, war and peacetime. In the peacetime, the foreign issues would generally be concerned of treaty disputes. How do you see if the Congress could do it in Zivotofsky given there would be no violation of existing treaty obligation of US? If not, but as stark with its international importance, should the Court deal with the substantial nature of passport policy? A considerable number of modern constitutions explicitly provides the presidential power of war emergency. How are the War Powers Act and court precedents compatible with the extent of such constitution? Respectfully.

Author: CHINWE MORDI Date: Friday, April 10, 2015 5:33:18 PM EDT Subject: RE: Discussion 2 - Week 6

\section{THE SUPREME COURT AND FOREIGN POLICY}

The tendency for Supreme Courts to restrain from foreign policy issues especially those that of political nature is commonplace. A good example is that of Zivotofsky v. Kerry (Zivitofsky vs Kerry, 2014). The matter concerned the registering of the place of birth of the child of an American couple born in Jerusalem as "Israel". This was in line with a law passed by congress that made for a provision for this opportunity on request. The state department refused as this recognition would derail the Israel/Palestine peace process and undermine the neutrality of the US foreign policy especially regarding this matter. The couple in return sued the state department and the matter has been up and down the courts with some courts arguing the validity of the issue as a political matter. (King \& Meernik, 1999)

The Supreme Court meanwhile decided to approach the matter choosing only to address if Congress violated the constitution in enacting the 2002 law thereby overruling the already existing state policy. They refused to be involved in the very political and highly volatile foreign policy. The effect of this ruling by the Supreme Court would affect the relationship between the tiers of government (congress and Executive) and also determine to what extent their powers reach especially as it relates to who enacts policies relating to foreign policies. 
Their lack of impact on this foreign policy means the neutrality of the US foreign policy in the peace process would be meanwhile maintained while the peace process goes on although internal interpretation (especially as it relates to their rights as American citizens) would continue to be sought in the courts.

Supreme Court intervention in politically related foreign policies is rare because of their sensitive nature but when they do interfere they aim for a balance and neutrality on all sides and establish that the president of the country had powers to enact foreign policies even without approval from the congress. (United States vs Curtiss-Wright Export Corp, 1936)

\section{References}

King, L. K., \& Meernik, J. (1999). The Supreme Court and the Powers of the Exceutive; The Adjudication of Foreign Policy. Political Research Quarterly, 801-824.

United States vs Curtiss-Wright Export Corp, 299 U.S. 304 (November 19-20, 1936).

Zivitofsky vs Kerry, 13-628 (Roberts Court(2010-) April 21, 2014). 


\title{
[Week 7]
}

\author{
Hi. Chinwe,
}

Thank you for the posting. Given the law has to realize various legal interests, the Court in Wyett might need to weigh between the specific justice and federal administrative interest. As the science and expertise in the field are important element especially in drug administration, can you simply imagine if FDA is less known with the subject matter than the state judges? If not, what made the lower court distinct to rule in finding the tort damages affirmatively? How are your convinced with the scientific community given prominent scholars suggest the floor truths remaining intact (hence less federal and more to rely on the common law)? And it seems also reminded if the common law is vastly within the state, and so extreme odd of federal common laws? Respectfully.

Author: CHINWE MORDI Date: Friday, April 17, 2015 4:36:37 PM EDT Subject: RE: Discussion - Week 7

\section{IMPACT OF FEDERAL PREEMPTION ON STATE POWERS}

This is generally known as the doctrine pf pre-emption. The doctrine of pre-emption simply means that whenever there is a conflict between a state law and a federal law, the federal law will take precedence or trump the state law. The doctrine of pre-emption serves to preserve the supremacy of the constitution. The supremacy of the constitution states that the constitution of the United States is supreme and every law or judgment that is in conflict with is null and void. The provision is provided of in the constitution in Article VI Clause 2 which states that

This constitution and the laws of the United States which shall be made in pursuance therefore; and all treaties made, under the authority of the United States, shall be the supreme law of the land and the Judges in every State shall be bound thereby, anything in the constitution or laws of any state to the contrary not withstanding

The case to be discussed is the case of Wyett v. Levine (Wyett v. Levine, 2009) in this case, the Plaintiff brought an action against the Pharmaceutical Company, makers of the drug Phenergan when she lost her arm to gangrene due to a side effect from the drug not listed. She argued that while the defendant met the requirement of drug labelling under state law, that it had inadequately labelled its drug under federal law, and citing the doctrine of preemption, the defendant was liable for the injuries she suffered.

The implication of this case was seen mainly in the field of public health policy. This case took a strong stand and held that the federal law pre-empts state law. By so doing, the case provided a recourse for redress for injured patients which would not have been so is the courts sided with Wyett because there were not protection provided for under the state law.

\section{References}

Wyett v. Levine, 550 (Supreme Court 2009). 


\section{Hi. Professor.}

Thank you for reading my post. The sedition act, officially the Alien Registration Act of 1940 and often called Smith Act to name after the bill proposer, still exists with three minor revisions on the penalty and definition of "organizes" or "organize." The provisions deal with subversive activities, deportation and alien registration, which caused a number of prosecutions involving the communists, fascist sympathizers and anti-Semites, crusader white shirts (attempting to spread dissent in the armed forces), isolationists or pro-fascist views in Washington 1944 trials. The Act was signed into law by President Roosevelt just before the days that France fell under the armistice with Germany. The European theatre of World War II turned radical to surprise the world at the overwhelming German troopers. The security of nation perhaps would aggravate requiring some of imminent action, which could stimulate this enactment. The provision simply is stranded with the words politically neutral, such as "violent...assassination... overthrow... clubs...society... membership..." Nevertheless, the criminal prosecutions on the basis of this act had been starker with typical classes as mentioned. While Germany was a very potential enemy at that time, the act might initially be spawned in that possibility, but the reality turned out over the next decades showed a different result. The strategies of communist would be agile and volatile, generally discreditable except their core idea of labor supremacy, as fifth column implies. The Spanish civil war would be one illustration, and they could readily shake hands with Hitler for nonaggression and other neutral purposes. Hence, the inchoate communists would also be a potential enemy, especially with the increasing threat of Soviet Union upon the end of World War II. The practical result of prosecutions reveals the nature of statutory purpose, say, protection of US governments and their offices, which sensibly requires some realistic potential so as to be prosecuted. Around 1950's, it is true that the threat of communism would be more probable and realistic, so that the trace with this act and on communism rather began in the American context around 1950's and we are generally known of McCarthyism. With this, we may say that the most powerful enemy may be governments of US itself or insiders as McCarthy broke in. The situation may, however, be viewed from nuclear threat that advises an importance of reduction of ICBMs, North Korean issue, as well as anti-terrorism newly discoursed as one important national security agenda since 1990's. The Missile crisis with Cuba in 1960s and new diplomatic compromise recently may signal a new viewpoint. There could we see points of legal implication on this Act.

First, the issue was purely criminal, in which the kind of acts generally are viewed as an essential ingredient and criminal interest to protect the sanctity and constitutional function of government.

Second, the problem can be raised in its practical use transgressing other area of constitutional or liberty values, such as freedom of expression or association.

Third, the interpretation and enforcement of Act would entail technical issues of criminal law. Generally the civil law theories would approach the "extent view" in which the probability of seditious conduct would be legally assessed so as to be successful of the violent overthrow of governments. Since it is crucial and sacred to protect the government in various concerns, the extent view is not strict meaning the "abstract chance of success" could be penalized. In other words, "concrete chance of success" may not be required in order for prosecutions. On this ground, Nazi sympathizers may be penalized on this statute, and racists would not be 
excluded although the chance of success to overthrow the state government is highly improbable. Since the federal governments ensure a Republican form of government for the states as a matter of Constitution, it can be seen as same to be safe with the federal government, but still be criminally pertinent with some group of civil activists.

Fourth, the hardship with this act against civil freedom had been a subject of academic forum. As John Gates pointed out in his book, The Story of an American Communist (1959): "To many in the leadership, this meant that the United States was unquestionably on the threshold of fascism. Had not Hitler's first step been to outlaw the Communist Party? We saw an almost exact parallel." The issue would be allowed a proper lens in US, which had been through the freedom of expression. In Yates v. United States, the Court distinguished between "advocacy of an idea for incitement" and the "teaching of an idea as a concept." The same day, the Court ruled 6-1 in Watkins v. United States that defendants could use the First Amendment as a defense against "abuses of the legislative process." In one case, President may exercise his power to pardon by commuting the criminal sentence as we see in the conviction of Junius Scales under the "membership clause" of the Smith Act. Respectfully.

Author: Kevin Fandl Date: Friday, April 17, 2015 6:38:47 PM EDT Subject: RE: Discussion - Week 7

Good assessment, Kiyoung. You raised the Nelson case here, which dealt with the Sedition Act. Does the Sedition Act still exist today? If not, how did that change its ability to preempt state laws allowing certain types of speech?

$\mathrm{KJF}$

Hi. Daniel,

Thank you for the informative post. I consider the federalism incurred a delicate consequence involving the traditional thought of criminal law. The maxim-no punishment without law-as required of duly enacted congressional act, seems to be perverted by the determination of Attorney General, who is merely one branch of state executive, never legislature. Given the federal regulations is to preempt the state act or constitution, the state act of this kind may be trumped as a matter of federalism which prevails the state level of political representation, however, under constitutional conditions. As the Court elicited, the congressional intent from CSA is to penalize a certain scope of crimes in the federal interest, neither to deal with the delegation of enforcement nor provide the ground to impede the action of state legislature. This simply illustrates the importance of congressional intent in delivering the federalism issue. Assuming if ODWDA was not enacted, do you see if the Attorney General is competent to prosecute the violations of CSA in the state court? If yes, how do you consider the federalism could mean? Respectfully.

Author: daniel hallman Date: Tuesday, April 14, 2015 11:02:23 PM EDT Subject: RE: Discussion - Week 7

Daniel F. Hallman, Jr., Discussion Post Week 7.

\section{Main Question Post:}


The case selected for this discussion post is the case, known as Gonzales v. Oregon (2006). Furthermore, this case exemplifies the Supremacy Clause within the Constitution Article VI, which states in pertinent part that:

This Constitution, and the Laws of the United States which shall be made in Pursuance thereof; and all Treaties made, or which shall be made, under the Authority of the United States, shall be the supreme Law of the Land; and the Judges in every State shall be bound thereby, any Thing in the Constitution or Laws of any State to the contrary notwithstanding. (U.S. Constitution, Article VI).

That within the aforementioned case "[i]n 1994, Oregon became the first State to legalize assisted suicide when voters approved a ballot measure enacting the Oregon Death with Dignity Act (ODWDA)" (Gonzales v. Oregon, 2006, p. 248). Additionally, the ODWDA regarding physicians' drug prescriptions were specifically regulated by and through the federal statute known as the "Controlled Substance Act (CSA or Act).... as amended, 21 U.S.C. § 801 et seq [which] allows... particular drugs to be available only by a written prescription from a registered physician" (Gonzales v. Oregon, 2006, p. 248). However, the Attorney General Gonzales "determine[d] that using controlled substances to assist suicide is not a legitimate medical practice and that dispensing or prescribing them for this purpose is unlawful under the CSA" (Gonzales v. Oregon, 2006, p. 248). Therefore, the issue before the Court is whether the CSA gives the Attorney General, the right to criminalize a doctor prescribing a lethal dose of medication to end a terminally ill patient's life despite the ODWDA. Thus, this is where the preemption argument erupts.

That pursuant to the CSA the "Attorney General has rulemaking power" (Gonzales $v$. Oregon, 2006, p. 258); however, the Supreme Court determined that "specific respects in which he is authorized to make rules... instruct us that he is not authorized to make a rule declaring illegitimate a medical standard for care and treatment of patients that is specifically authorized under state law" (Gonzales v. Oregon, 2006, p. 248). Additionally, the Attorney General if and when utilizing rulemaking authority must do so pursuant to the Administrative Procedure Act (APA), 5 U.S.C. $§ 553$ (Gonzales v. Oregon, 2006). Therefore, because the attorney general did not utilize the APA accordingly that "it cannot fall under the Attorney General's 'control' authority" (Gonzales v. Oregon, 2006, p. 260).

Moreover, that the Supreme Court also elucidated that "[t]he idea that Congress gave the Attorney General such broad and unusual authority through an implicit delegation in the CSA's registration provision is not sustainable" (Gonzales v. Oregon, 2006, p.

267). Subsequently, the Supreme Court also articulated, "the CSA does not give the Attorney General authority to issue the Interpretive Rule as a statement with the force of law" (Gonzales v. Oregon, 2006, p. 268). Lastly, the Supreme Court held that "[t]he text and structure of the CSA show that Congress did not have this far-reaching intent to alter the federal - state balance and the congressional role in maintaining it" (Gonzales v. Oregon, 2006, p. 275). Therefore, the lower Court's ruling was affirmed and that the Attorney General did not have the right under the Interpretive Rule pursuant to the CSA to fundamentally establish that the ODWDA was an illegitimate use with criminal implications (Gonzales v. Oregon, 2006). The Supreme Court enforced that within the aforementioned case the State's power to enact the ODWDA was a regulatory right and intrinsically "did not authorize preemption" (Linder, 2009, para. 13). This was a significant impact on how a state 
statute could not be negated by the State's Attorney General utilizing a federal Act or the CSA when trying to establishing preemption pursuant U.S. Constitution, Article VI.

Resources

Administrative Procedure Act, 5 U.S.C. $\$ 553$

Controlled Substance Act, 21 U.S.C. $§ 801$ et seq

Gonzales v. Oregon, 546 U.S. 243 (2006)

Linder, D. (2009). The Supremacy Clause and federal preemption. Retrieved from http://law2.umkc.edu/faculty/projects/ftrials/conlaw/preemption.htm

\section{U.S. Constitution, Article VI}

Daniel, great case. From the language that you referenced here about the powers of the Attorney General, it sounds as though this is really a federalism issue. If the AJ cannot override the rulemaking authority of the state, does that mean that the federal government is not authorized to act in this area?

$\mathrm{KJF}$

Hello Prof.;

Thank you for the post and question. My understanding is that the Atty. Gen. was trying to make the Oregon State Act a criminal offense by utilizing the CSA. However, after the Supreme Court reviewed the CSA they determine that the Atty. Gen. did not have the ability to do so by utilizing the CSA. It's an interesting case because at first glance it seems that the Supreme Court is going to address assisted suicide, but they chose to look at how the Atty. Gen. was trying to criminalize an existing State Act by a Federal Act. When researching cases regarding preemption this was a case often cited. Additionally, this case also came up within our reading list by Linder (2009). Thanks again for the question and post.

- Daniel.

Resource

Linder, D. (2009). The Supremacy Clause and federal preemption. Retrieved from http://law2.umkc.edu/faculty/projects/ftrials/conlaw/preemption.htm

Hi. Chinwe,

Thank you for reading my post. Three points may be pertinent. In my consideration, the state elections could be administered within the autonomy of state, so that consistency and uniformity may be fine, but are not mandatory except for the constitutional requirements. However, since the Republican form of government is not to be abandoned, the state could not adopt an unusual election method. This aspect also is vindicated by the Amendments, which concern an equal right to vote. Second, if you say the state elections broadly to cover the federal elections, the consistency and uniformity would be critical to guarantee a fair and 
sensible election. We can use soft law approach provided if the uniform national administration act hypothetically were to be awkward. The national standard from ABA or ALI could help to inculcate that the state-based election laws could be congenial to the echelon of federal public offices. Third, the state election laws generally do not distinguish between the state and federal elections that both elections are common in attribute. Hence, the interstate cooperation to study and exchange views would possibly help to increase consistency and uniformity. Respectfully. 


\section{[Week 8]}

Author: CHINWE MORDI Date: Friday, April 24, 2015 7:04:15 AM EDT Subject: RE: Discussion - Week 8

Hello Kiyoung,

I enjoyed reading your post. what will you suggest as a way of ensuring consistency and uniformity across state elections?

Cheers,

Chinwe M

Author: Elizabeth Davis Date: Thursday, April 23, 2015 5:24:56 PM EDT Subject: RE: Discussion - Week 8

One of the most important rights we have as individual have in the United States is the right to vote. The right to vote is so important that the U.S Supreme Court has declared it to be fundamental (Vile and Menez, 2010). Federal elections are held in each state and each state have different rules as to how the elections will be conducted. Government must play an active role in structuring elections and the electoral process. Consequently, individual states carry out the electoral process by following their own state laws according to Sections 2 and 4 of Article I of the U.S. Constitution (https://www.law.cornell.edu/wex/elections).

A strength involving states in the presidential elections is that they are allowed to choose their own Electors. The citizens have an opportunity to cast their vote as to who they believe will be the best presidential candidate. One limitation of the role of state governments in presidential elections is that the states have no control as to when their citizen in their state can vote in the federal elections. These dates are set by Congress. Congress' authority to regulate congressional elections comes from Article I, Section 4, Clause 1 of the Constitution as known as the Election Clause which provides that the states can prescribe the places, times and manner of congressional elections, and that Congress can makes changes to states' regulations at any time except for choosing Senators

(www.gao.gov/new.items/d01470.pdf). One can see why states role in presidential elections is both positive and negative. States do have a responsibility to their citizens to ensure that they voting rights are not being violated so that they can participate fully in each elections. Resources Elections (n.d.). Retrieved from, https://www.law.cornell.edu/wex/elections. The Scope of Congressional Authority in Election (2001). Retrieved from, www.gao.gov/new.items/d01470.pdf.

Vile, J. R., \& Menez, J. F. (2010). Essential Supreme Court decisions: Summaries of leading cases in U.S. constitutional law. Lanham, Md: Rowman \& Littlefield Publishers.

Hello Elizabeth,

I enjoyed reading your post it was very succinct. I also felt that a positive attribute granted to individual states was the ability to select their own electors by and through votes from their citizens. However, my question would be, do you think that in presidential elections states should have self-autonomy over disputes that arise within their voting practices? 
Alternatively, should the federal government have the final say with in presidential elections? Again, I enjoyed reading your post and I look forward to your rejoin.

- Daniel.

Daniel,

Thanks for responding to my post. I do believe that states should have self-autonomy over disputes involving voting practices in presidential elections. The federal government should only intervene in extreme rare cases involving voting practices. The federal government should not have the final say with a presidential elections being that this would discredit an individual right to vote.

Elizabeth

Author: Precious Clayton Date: Friday, April 24, 2015 1:19:12 AM EDT Subject: RE: Discussion - Week 8

The role of the state government in presidential elections have many strengths and limitations. A limiting factor is when tend to relocate and cannot meet the residency requirements for the new state which in return prohibits them from voting absentee in the old states (Gardner, 2001). One strength that the presidential elections provide for the state is to involving states in the presidential elections is that they are allowed to choose their own Electors (Gardner, 2001). Because every state has its statutes on elections, its voting procedures, voting equipment, numerous ballot boxes and voting materials will constitute preponderance of problems. States have a responsibility to their citizens to ensure that they voting rights are not being violated so that they can participate fully in each elections (Gardner, 2001). I feel as the federal government should not be involved within the regulation and administrative unless the issues has reached the Supreme Court and need the assistance. The intent of the Founders was to separate powers with the Supreme Court serving as an independent branch of the Federal government (Vile, 2010). The powers with the Supreme Court serving as an independent branch of the Federal government (Vile, 2010). There should be a set law and a law of separation to help everyone balance their responsibilities as well as the Checks and Balance.

Reference Page

Gardner, A. J. (2001). The Regulatory Role of State Constitutional Structural Constraints in Presidential Elections. Florida State University Law Review, Vol. 29:625-659. Retrieved from, http://archive.law.fsu.edu/journals/lawreview/downloads/292/Gardner.pdf Vile, J. R. (2010). Essential Supreme Court decisions: summaries of leading cases in US Constitutional law. Roman \& Littlefield Publishers. Voting Rights Act in 1965 (52 U.S.C. $\S$

U. S. Electoral College. (n.d). What are the Roles and Responsibilities of the Designated Parties

in the Electoral College Process?. Retrieved from, http://www.archives.gov/federalregister/electoral-college/roles.html\#states

Author: CHINWE MORDI Date: Friday, April 24, 2015 7:18:34 AM EDT Subject: RE: Discussion - Week 8 
interesting discussion post, does the requirement for residency not violate the constitutional right to vote? what do you think?

Cheers,

\section{Chinwe M}

Hi Precious:

Do state regulations that limit the ability to vote once relocated violate our voting rights? Do you think that federal intervention in this matter would allow for more fairness? I agree with the notion of separation of powers and states' rights, but if it is infringing on citizens' rights should there be some change?

Thanks so much.

Whitney

Hi Precious,

I enjoyed reading your post. I'm I correct in saying you do not feel the federal government should get involved with states' administration and regulation of voting until the Supreme Court gets involved? The Constitution also gives Congress the authority to limit states to keep them from infringe on the rights of the people. By the time an issue is challenged in the Supreme Court many people will have suffered when Congress has the ability to ease that suffering through legislation which at times may be quicker than the Supreme Court decision. How do you feel about national control over activities by states that may result in infringing on the rights of some people? Your post was interesting.

Regards,

Tina

Hi. Precious,

I have enjoyed reading your post. As peers commented, the view that Congress would get better regressive in the federal election seems challenging. The Congress is one important branch of tripartite government that would be a defender of Constitution. For instance, the requirement for residency can be made uniform across the States by enacting the statute from the ruling of Supreme Court. The right to travel also is a fundamental right for citizens that should not be abridged. Both branches collaborate to bring the rule of Constitution. Thank you for the good post, and your thought? Respectfully. 


\title{
[Week 9]
}

Author: Whitney Root Date: Tuesday, April 28, 2015 11:16:45 PM EDT Subject: Main Post Discussion 1 - Week 9 (Against)

\section{Judicial Constraints and Entitlement and Benefits Programs}

\begin{abstract}
Against
Both the $5^{\text {th }}$ and $14^{\text {th }}$ amendments to the Constitution guarantee that no individual shall be "deprived life, liberty, or property, without due process of law" (Cornell University Law School, 2015a \&2015b, I11). Adherence to the due process clause was challenged in both case readings this week, Goldberg v Kelly (1970) and Mathews v Eldridge (1976), in which individuals receiving program benefits were removed from such benefits either without prior warning and/or the ability to participate in a hearing regarding the changes.
\end{abstract}

In Goldberg v Kelly (1970) it was determined that, prior to removing individuals from state-funded entitlement programs, the state must provide the beneficiary with an evidentiary hearing so as to abide by procedural due process guarantees. Mathews $v$ Eldridge (1976), however, ruled that Social Security Disability beneficiaries did not require the holding of a termination hearing before benefits would stop. The Court held that due process was not violated in this case because ample notification is provided prior to termination of benefits, with numerous ways in which to safeguard against errors to benefit discontinuation. Unlike the beneficiaries as demonstrated in Goldberg v Kelly (1970), Social Security Disability recipients were given ample warning prior to being terminated from the program. It was further suggested that welfare recipients are individuals in dire need of aid - food, shelter — while disability beneficiaries are not considered for benefits based upon financial need.

Judicial interference on legislative matters as pertaining to benefits programs is touchy. Individuals who are on such programs - be they welfare or disability - are on these programs for a reason. For the Courts to determine, procedurally, how such matters should be handled might be stretching it a bit. The purpose of the Court is to interpret the Constitution. In cases as described above the Courts have no immediate interactions or understanding of the workings of such programs. The elected representatives are the individuals who are [supposed to be] more in tune with the needs of constituents and the workings of state happenings. Sometimes changes need to be made on a case-by-case basis. Getting the Courts involved could place restraints on individuals in need across the board, even if their situation may call for slightly altered means of dealing with a problem. For these reasons, I am against judicial constraints on benefits programs.

\section{References}

Cornell University Law School. (2015a). Amendment V. Retrieved from, https://www.law.cornell.edu/constitution/fifth_amendment

Cornell University Law School. (2015b). Amendment XIV. Retrieved from, https://www.law.cornell.edu/constitution/amendmentxiv 
Goldberg v. Kelly, 397 U.S. 254 (1970)

Mathews v. Eldridge, 424 U.S. 319 (1976)

Hi. Whitney,

Thank you for the good post. The court saw it needed of distinguishing between the recipient of dire need of aid and disability benefit. It also ruled that the due process of law requires constitutionally adequate notice or hearing opportunities. Depending on the nature of entitlements and severity of conflict of interest, the extent of institutional arrangement afforded to the aggrieved party would be austere judicial-type proceeding or compact procedure. This frame generally is considered to function as a bulwark of rule of law ideal against the arbitrary and discriminatory administrative action. As you stated, the court role would be touchy, and the legislation or executive often is a main player. The court also tends to render a practice of deference unless the issue does not raise a significant legal disagreement. Nevertheless, the court role has been consequential with the protection of basic right, such as the first amendment right and equal protection of law, and prevents a gross failure of policy consideration. For example, the disabled person can be made distinguishable from a general scope of need based programs as the Court perceived. Given the judicial constraints are not good way of approach, do you generally disagree if the court is the forum of last resort to find the constitutional rights of beneficiaries? Respectfully.

(Against). I'm against judicial constraints on legislative efforts to create, expand, and/or constrain entitlement and benefits programs. In regards to entitlement and benefits programs the Supreme Court should not get involved not unless it involves a clear case in which the Due Process Clause of the Fourteenth Amendment has been violated. A prime example of the Supreme Court inconsistencies involves both cases, Goldberg v. Kelly (1970) and Matthews v Eldridge (1976). Goldberg v. Kelly (1970), 7-to-2 decision, the Court held that states must afford public aid recipients a pre-termination evidentiary hearing before discontinuing their aid. They stated that welfare benefits are statutory entitlements, rather than "privileges (http://www.oyez.org/cases/1960-1969/1969/1969_62). Matthews v. Eldridge (1976), the court ruled 6-to-2 that the initial termination of Eldridge's benefits without a hearing did not violate due process. The Court noted that due process was "flexible" and called for "such procedural protections as the particular situation demands." (http://www.oyez.org/cases/1970-1979/1975/1975_74_204).

Being that there are many individuals who depend on the entitlement and benefits to survive I personally don't want to see that the court rule inconsistently. How can the courts really determined if certain programs are in violation of an individual due process without knowing the background behind each case? The reason being is that the Supreme Court has too many cases to hear and to make formal decisions that can affect everyone as a whole. The Supreme Court is a busy place, it's not always clear that the justices have a real opportunity to see beyond the case at hand to see it effects upon the doctrine, or body of national law (Wald, 1990).

There would be times when it will be necessary to use judicial constraints on legislative efforts dependent upon extreme circumstances. Administrative agencies created on behalf of the legislative branch to handle social problems. Administrative agencies have two major functions: rulemaking and enforcement (adjudication). The Administrative Procedure 
Act provides the rulemaking requirements, hearing procedures, and adjudicatory standards and procedures for federal agencies

(http://www.loc.gov/law/help/administrative.php). The administrative agencies have to have an oversight committee to ensure that they following the rules and regulations and to make sure that the rules are so ambiguous for the general public.

References

Goldberg v. Kelly, 397 U.S. 254 (1970). Retrieved from http://www.oyez.org/cases/19601969/1969/1969_62.

Guide to Administrative Law (n.d.). Retrieved from, http://www.loc.gov/law/help/administrative.php.

Mathews v. Eldridge, 424 U.S. 319 (1976). Retrieved from http://www.oyez.org/cases/19701979/1975/1975_74_204.

Wald, P. M. (1990). Government benefits: A new look at an old gifthorse. New York University Law Review, 65.

Hi. Elizabeth,

I have enjoyed reading your post. I am sympathetic with your view that the administrative agencies' role is primary to respond with the desire and aspirations of public. They are a firsthand government, and creative to distribute a specific justice. Nevertheless, the law and public policy would not always come consonant to deal with challenges. Worse, the political influence to bias a fair and neutral administration could be present -- in not entirely negative sense if politics is nothing but to be present in the end -- but should be checked, to say, for the rule of law or constitutional right. For example, Lyng can be seen as skeptical if the rigged liberalism may undermine a socially proven due status of unionism. In the concern, some would argue on the activism of judiciary for social progress. Your thoughts? Respectfully.

\section{Kiyoung,}

Thanks for responding to my post. I would definitely agree that the Supreme Court in needed to intervene on some issues regarding to social progress. I just don't like when there are inconsistencies in their rulings. They can have cases before them that are somewhat similar and yet ruled totally opposite. Once politics comes into play there is no guarantee that the government will play fair no matter how many lives that they will or can personally affect.

Elizabeth

\section{Tina Brooks}

RE: Discussion 1 - Sheron's response to Tina's post: Reply to Sheron

COLLAPSE

Hi Sheron, 
Thank you for responding. Most people pay taxes in some form so very few fall into the category of non-taxpaying. Just as some states have income tax and some do not. This does not mean the residence of the state without income taxes does pay taxes. Those states usually have higher sales taxes to compensate. Most prisons in the US have reform programs that allow prisoners to opportunity to get an education or learn a trade which is more opportunity than a low income single parent be they male or female. The objective of welfare should not be to sustain someone who is producing children they can't afford to care for or raise. It should not be burdened upon other taxpayers to support someone who does not practice restraint or fails to plan according to means. While, there will always be instances when we all need help and assistance in life. Welfare programs should only be a temporary stepping stone. Personally, I think they should go hand in hand with some sort of educational or vocational development program that assists the individual into achieving above minimum wage employment. But in reality, there is no program can make someone want to obtain a better quality of life and some individuals are happier making minimum wage.

I know from experience that, yes, most people want to work. I, also know, there are still quite a few people who feel society owes them and don't want to work. I'm not very sympathetic to parents that commit crimes two or more times nor do I have sympathy for murderers and thieves. Exercising a lack of control and antisocial behavior as a parent to me is a form of child abuse. I would never wish for any child to be in that type of environment. Don't misconstrue what I am saying. Good people make mistakes and are sometimes convicted of crimes they may not have committed or done intentionally. Our judicial system is not perfect. But, research has found that criminal behavior is lower in countries that do not reward such behavior. Also let me enlighten you to my definition of criminal, I believe a criminal is someone who habitually breaks the law (commits a minor crime more than once) or commits a significant infringement to the rights, safety and welfare of others (e.g. murder, assault, robbery, drive by shooting, kidnapping and so on). The money taxpayers invest in the prison system is supposed to reform convicts prior to leaving prison. There are not a lot of jobs available for people who have not committed a crime. Should they fare worse than someone who has spent time receiving three meals a day that they haven't worked for and education that they didn't have to pay for in the name of rehabilitation? Should that struggling single parent take a backseat to someone who harmed another human being because they wanted what that person had but didn't want to work for it? Should our welfare system support someone's addictions over someone who is working hard to improve their quality of life and that of their children?

I know you think I am harsh but I've come from a very poor background and I watch those that were honest and hardworking excel through sacrifice, restraint, and diligence. I've also watched those who made a career of going in and out of prison and those who learned from their mistake and excelled. I don't feel taxpayers should have to bear the burden of supporting career criminals. I don't feel career criminals should be allowed to raise children either. This is my opinion. As a society, we will continue to support everyone that meets the qualifications or criteria for the benefits or entitlement programs. As a veteran and a public servant, I will continue to serve the people of my country be they criminal or not. My private feelings on the matter do not change the laws that govern this country and while I may not agree I will not infringe on the individuals rights of these individuals to seek and obtain the benefits and entitlements for which they qualify. 
Thank you for your response. It was very stimulating.

Regards,

Tina

Hi. Tina,

I have enjoyed reading your post. The idea from other countries, for example, Germany and Korea, is that the people or nationals, in the frame of modern constitutionalism, have three distinctions in its status. First, people or nationals are sovereign to enact the Constitution as a supreme law of land. Second, people are electors to create the branches of government, for example, within the tripartite system in the US or five supreme organs in Tiwan. Third, people are the entertainer of constitutional right as an individual. Fourth, people are the subjects to be ruled by the government. As you stated, it seems not irrelevant that the Court has been overly static to see the government an inviolable machination and the kind of omnibus surveyor largely undisputable. I am toned with your statement. People would not merely be a vulnerable individual, but prescribed basically to the rule of constitution deeply. Nevertheless, the government generally tends to resort in their own superior way?

Respectfully.

\section{Daniel F. Hallman, Jr., Discussion Post 2 Week 9.}

\section{Main Question Post:}

The case selected in order to illustrate the Court's role in protecting individual's rights pertaining to benefits is the case known as Califano v. Goldfarb, (1977). Furthermore, within the aforementioned case the primary argument is whether a husband of a deceased wife is fundamentally entitled to Social Security survivors' benefits without establishing that half of his support was directly derived from his wife during her time of employment while both were paying into Social Security benefits. Moreover, that pursuant to "42 U.S.C. $\S 402$ (f) (1) (D), such benefits on the basis of the earnings of a deceased wife covered by the Act are payable to her widower, only if he was receiving at least half of his support from her" (p. 199). Therefore, the primary issue as to whether 42 U.S.C. $§ 402$ (f) (1) (D) violated the Due Process Clause of the Fifth Amendment. Additionally, the United States Supreme Court would also posit as to whether 42 U.S.C. $\S 402$ (f) (1) (D) was discriminatory in relation to gender-based "distribution of employment - related benefits" (Califano v. Goldfarb, 1977, p. 217).

Subsequently, the United States Supreme Court did establish that "'[b]y providing dissimilar treatment for men and women who are... similarly situated... violates the [Fifth Amendment]'" (Weinberg v. Wiesenfeld, 1975; as cited within Califano v. Goldfarb, 1977, p. 207). Furthermore, that the United States Supreme Court further elucidated that 42 U.S.C. $\S$ 402 (f) (1) (D) did in fact create "gender - based discrimination in the distribution of employment - related benefits" (Califano v. Goldfarb, 1977, p. 217). Moreover, the Court came to this relevant conclusion that the archaic ideology that a woman is always dependent upon a husband and that a husband is seldom dependent upon his wife is no longer realistic dogma (Califano v. Goldfarb, 1977). Additionally, the United States Supreme Court also elucidated that because both were paying into Social Security that both are equally afforded 
the same protection and that pursuant to 42 U.S.C. $§ 402$ (f) (1) (D) that "female workers [were] required to pay Social Security taxes [however] producing less protection... [which] is forbidden by the Constitution" (Califano v. Goldfarb, 1977, p. 206). Therefore, the aforementioned case is a prime example of when the judicial system had to establish entitlement provisions in order for men to receive the same entitlements as women regarding the survivors' benefits within the Social Security Act.

\section{Resource}

42 U.S.C. $§ 402$ (f) (1) (D)

Califano v. Goldfarb, 430 U.S. 199 (1977)

Weinberg v. Wiesenfeld, 420 U.S. 636 (1975)

Hi. Daniel,

Interesting post that shows a paradigmatic example involving gender equality, family, social and economic reality of ours. Really a good selection to share and the Court seems very progressive and realistic. Now the labor market had shifted with the professional and advanced ways of production as differs from agriculture, fishery, hunting and muscle-based work frames. The female workers are abundant to make it outdated from traditional role of gender in the family relations and labor market. Now half of judges and state attorneys are female lawyers in Korea while the national pension is now being taunted of struggles and acid public debate of significant reform. The growth rate of national economy had been, and still is the touchstone of government success in Korea, which would not be irrelevant in the US. The female labor force will significantly be contributive than the past.

As the Court said, I agree that the archaic ideology within the traditional notion of gender role seems highly impertinent with the contemporary reality. Nevertheless, I am not entirely with the majority court if we may duly subject the male role to do more than females in terms of economic production. That would never penalize them if the primacy stems from his wife's contribution, and if with no sufficient ground to contribute financially or in other way. The kind of equality seems mechanic and impermissibly less substantiated if we consider all the ways half to half about the security benefit of deceased spouse between different sexes. The situation of widower-- for example, if he is disabled or economically affordable -- could be considered in enactment. We may get extreme with undesirable woman in the families, but they are generally expected of some differences in nature and order. Some less ratio of entitlement to the widower than widow could be conceived. I may state if it would be less sensible that the widower could expect or claim entirely same treatment, it being likely against the general imagery of nature within this inartificial and natural heterogeneity as also arguably unique. Therefore, it would not "penalize them" since their expectations for entirely same treatment seems neither created nor vested within their minds. Respectfully.

Hello Kiyoung,

Thank you for the interesting rejoin. I agree that gender equality is essential for economic growth, because, as you stated, that much of the workforce is becoming dominated by women. 
Hence, there should no longer be any gender inequality. However, despite how many women are within the workforce, that they primarily only work within middle management. Whereas, nearly $97 \%$ of all CEOs are still men and that this is a disparity that needs ratification. Thanks again for your post and I look forward to any future discourse.

- Daniel.

Emmanuel Nwosu

RE: Discussion 2 - Week 9

\section{Protection of Individual Entitlement}

\section{Main Dicussion Post}

\section{Case Selected: Gay couple ruling}

Following the 1996 Defense of Marriage Act which denied health care coverage to gay couples, a federal judge of the U.S. 9th Circuit Court of appeal ruled that benefits of Sears to be discriminated on the sexual orientation, a violation of the state law and unconstitutional denied due process.

Brad Leveson a lawyer with federal public defense is married to Sears a man (gay couple), had applied for health care coverage and other benefits" for Tony Sears after their marriage and was denied. By then, same-sex marriage was legal in California for five months until Proposition 8 which defined marriage as between one man and one woman upturned it. However, Leveson had applied for benefits, Stevens Reinhardt a circuit judge had ordered the Adimistrative Office of the U.S. Courts to process Leveson's application for spousal benefits. At that stage, the Federal Office of Management stepped in to stop further processes citing the Defense of Marriage Act of 1996.

Citizens have constitutional rights to sue when they are denied their benefits, and it is the responsibility of adminstrative courts or any courts for that matter to determine whether such denial is constitutional or not. The citizen must sue to court to address the violation. In Leveson's case, at the time of their marriage same-sex marriage was legal and they were entitled to their benefits. But judge Reinhardt erred in law to have ordered for payment of benefits when in fact, it is preempted by federal law. The preemption of federal law expressly applied therefore the federal law occupied the "field".

\section{References}

Course Lecture Notes (2015)

Williams, C.J. (2009 November19). Gay couples win ruling. A federal attorney is to be repaid the cost of associated with his husband's being denied health care coverage. Ls Andeles Times, p.46

Hi. Emmanuel, 
Thank you for the good post. It seems an interesting post that the hierarchy of laws and federalism guided the constitutional liberty to marriage. Although the issue of marriage touches on the common nature of human being, it can be seen differed among the states and federal scope of personnel. This dealings, in this reality, are applied than natural to the order of being, but I generally do not disagree if gay marriage is to be invalidated for the purpose of federal scope. Do you consider it controversial if the federal act is challenged of its unconstitutionality? Respectfully.

Hello Kiyoung,

Thank you for the feedback. In fact, and as you know, America is a country of law therefore, citizens have the right to challenge any act of both federal and states law they consider unconstitutional.

...Emmanuel

\section{Precious Clayton}

RE: Discussion 2 - Week 9

Post a brief summary of the case you selected. Then explain how it illustrates the role of the courts in protecting individual entitlement to receive benefits. Be specific

The Case I have selected is the Goldberg vs. Kelly, in which the case was brought by residents of New York City who received financial aid under the federally assisted program of Aid to Families with Dependent Children (AFDC) or under New York State's Home Relief Program (Goldberg vs. Kelly, 2015). Their complaint alleged that City officials administering these programs terminated such aid without prior notice and hearing, denying them due process of law (Goldberg vs. Kelly, 2015). After the suit was filed, the City adopted procedures for notice and hearing, which the plaintiff-appellees then challenged as constitutionally inadequate (Goldberg vs. Kelly, 2015). The procedure allowed the recipient to challenge the proposed termination of benefits within seven days and submit a written statement for the reviewing official to make a final determination (Goldberg vs. Kelly, 2015). Appellees' challenged the procedures' lack of an opportunity to personally appear before the reviewing officer for oral testimony and cross-examination of adverse witnesses (Goldberg vs. Kelly, 2015). The procedure did allow for a post-termination "fair hearing," however (Goldberg vs. Kelly, 2015). The District Court held that only a pre-termination hearing would satisfy the constitutional due process requirement (Goldberg vs. Kelly, 2015).

The courts affirmed that due to the agency not giving notice of the termination of aid, it was a violation of the citizens due process in which requires a pre-termination hearing prior to termination of welfare benefits (Goldberg vs. Kelly, 2015). The courts stated that the Court held that states must afford public aid recipients a pre-termination evidentiary hearing before discontinuing their aid (Goldberg vs. Kelly, 2015). Noting that welfare benefits are statutory entitlements, rather than "privileges," the Court weighed welfare recipients' need for procedural due process against the competing considerations of the possible harm they might suffer from discontinuation and the government's interest in summary adjudication (Goldberg vs. Kelly, 2015). The Court concluded that state interests in conserving administrative costs 
are not sufficient to override public aid recipients' interest in procedural due process (Goldberg vs. Kelly, 2015).

Reference Page

Goldberg v. Kelly, 397 U.S. 254 (1970).

Goldberg vs. Kelly. (2015). The Oyez Project. Retrieved from http://www.oyez.org/cases/1960-

1969/1969/1969_62

\section{Hi. Precious,}

Thank you for the good post. I generally agree that Goldberg v. Kelly is an important case to succinctly illuminate on the specific justice of beneficiaries and intended purpose of public policy. While we are issued of traffic citation, we would be given a notice and chance to dispute in the court proceedings. Even in that case, we may be disgruntled with the abuse of rule if he or she has a good defense personally and given the license suspension takes effect $a$ priori, but only post-suspension hearing is afforded. Considering the deprived people, the consequence would amount more seriously who should be tougher from a discontinuation of aid. Respectfully.

\section{Hi. Professor,}

Thank you for the question. We can possibly state that the statute would be more intrigued and refined in provisions and terms. This view also supposes the constitution could include more ambiguities in language since it is general of whole gamut of people-to-government relationship, hence widest, but with limited pages than such stack of statutes. As we are practical, that is not always true, and it would be a kind of chi-square between very clear and straightened provisions and ambiguous area or provisions. The foreign policy and war power would be one, and the eighth, ninth as well as some other amendments would also be such class. One important difference between the Constitution and statute is that the statute would be living around the variable time of enactment once the Constitution-notwithstanding the later amendments -- is fixed far earliest in time, more than two hundred years ago. Therefore, we may need to consider the telecommunication service and net neutrality policy relating with the 1990's Act. The statutory term of "telecommunication service" and "information service" would be ruled by FCC and be submissive to the interpretation of agency. Although the dispute can be brought to the Supreme Court, the Chevron rule would effectively work to respect the interpretation of FCC. Generally, the interpretation of statute is finally supervised by the Supreme Court against the arbitrary or gross failure of fairness. The Chevron doctrine has an effect that would defer a fair of substantial role -- to interpret and resolve the ambiguities -- to the agencies on the specific field. The context would provide a good comparative point between the "statute and constitutional interpretations" involving the originalism and living document philosophy. Two differences may arise if the originalism would be less in impact except for the consideration of legislative history involving the statute interpretation. The kind of living document concept would be more in prevalence in it? The other is that the statutes can be frequent to respond with the evolving public needs -especially the development of science and technology as well as the increasing role of state. 
In that context, I suppose if the Court would exercise more on the Chevron role with judicial deference if the professional and technical issues are involved. Respectfully.

Author: Kevin Fandl Date: Thursday, May 7, 2015 8:52:43 PM EDT Subject: RE:

Discussion 1 - Week 10

This is quite an extensive discussion. You began by discussing the language in statutes (which would not include the Constitution, by the way). When congress passes a statute and that statute is clear on its face, what is the role of the Court? Who determines whether the language is clear and what standard is applied in doing so?

KJF 


\section{[Week 10]}

Hi. Tina,

Thank you for the good post. You are not mistaken that the judicial proceedings generally are impressive with delay and time consuming event, but with a hardship on the parties alleging an injury or loss. Hence the speedy trial had been prescribed to protect the criminal defendants within the Constitution. WTO agreements, such as DSU and Agreement on Safeguard Measure, had been improved with the clear provisions of definite time frame. As Daniel saw, the Court can have a limitation with the ripeness or mootness doctrine leading to a decade of delay or sudden refusal to provide a remedy. That would arise from the technical issue of law, but I may add if the heavy workload and procedural austerity could make the problem unavoidable. How do you consider if the Certiorari system would even create the conditions for the deprivation of reviewable opportunities? Respectfully.

Author: Tina Brooks Date: Wednesday, May 6, 2015 9:53:00 PM EDT Subject: RE: Discussion 1 - Week 10; Main Post

\section{Supreme Court's Interpretation of Ambiguous Constitutional Language Tina Angela Brooks}

\section{Supreme Court's Interpretation of Ambiguous Constitutional Language}

The purpose of this discussion is to identify two strengths and limitations relating to the Supreme Court's interpretation of ambiguous constitutional language. The United States Supreme Court has the final say in the interpretation of the Constitution, regulations and laws. Their strength lies in majority ruled opinions in cases with dissenting judges (District of Columbia v. Heller, 2008; Grutter v. Bollinger, 2003). Although, the judges are not in complete accord about a whole issue, those parts of the issue that majority agree upon are in the opinion. In the case of Gutter v. Bollinger, four judges held the use of race as unconstitutional while three judges rejected the majority's Marks analysis (2003). Another strength of the Supreme Court is that future Supreme Court justices have the ability to challenge past interpretations and form their own opinions (Pardo, 2005). From the blending of the fourth and fifth Amendments in the Court's opinion in the case involving Boyd v. United States to the separation of the two Amendments with recognition of the relationship the Amendments share. The limitations the Court seems to exhibit habitually over the passage of time is trying to interpret that hearts and minds of the authors of the Constitution (District of Columbia v. Heller, 2008). The Courts opinions and decisions are based upon a period of time when the country was young and lot more unlawful than today. The amount of law enforcement was meager and the distance between areas with law enforcement was grand in comparison to today's society. Majority of the country was rural and unexplored. The need to protect yourself was grounded in the ability to communicate the need for assistance and the time it would have taken to report a crime. This limitation provides the impression that the Court's interpretation is grounded in the past with little regard for the current state of society and modern technology. Another limitation is the amount of time it takes to reach a Supreme Court decision. The original law suit in the case of Grutter v. Bollinger was filed back in 1997. Ms. Grutter could have obtained a Master's Degree in the time it took for the case to reach decision Supreme Court. 
The conclusion is that the Supreme Court's interpretations concerning ambiguous constitutional language in the making of policy can be obsolete and at times too little too late by creating barriers to society policies that are designed to protect the masses in increasingly populated urban areas at times or correct a previous injustice; or, the Supreme Court's interpretations of the Constitution could provide clarification of the distinction between two or more Amendments that are closely related promoting policies that further clarify the Amendments strengths and limitations in relationship to government power and authority.

\section{References}

District of Columbia v. Heller 554 U.S. 570 (2008)

Grutter v. Bollinger et al. 539 U.S. 306 (2003)

Michael S. Pardo, Disentangling the Fourth Amendment and the SelfIncrimination Clause, 90 IA L. REV. 1857 (2005).

Hello Tina,

I enjoyed reading your post. You had mentioned many times Supreme Court rulings or their pertinent holdings are established in a non-timely fashion. It is true that it can take years for the Supreme Court to hear a subsequent case; however, this essentially is because there needs to be an exhaustion of all lower courts before the Supreme Court will consider the issue. I.e., they are the arbiter of last resorts. However, the question that I would pose is that, do you think that the Supreme Court will only initiate policy issues that are intrinsically ripe within society? E.g., do you think the Supreme Court would have heard a case regarding same-sex marriages 25 years ago? Again, I enjoyed reading your post and I look forward to your rejoin. Good luck on your final project.

- Daniel.

Hi Daniel,

As you pointed out our Supreme Court is the last court in a list of lower courts. So of course, they will not initiate any issues unchallenged. In the case of Singer v. the United States Civil Service Commission, the Court became aware of a man who was openly homosexual. Mr. Singer tried to apply for a marriage license with another man in 1971. The Superior Court of Washington decided Washington's statutory prohibition against same-sex marriages did not violate any constitutional right. The Supreme Court of Washington denied the petition for review.

Thank you for responding. Best wishes on your final project.

Regards,

Tina

Singer v. the United States Civil Service Commission 429 U.S. 1034 (1977)

Hi. Daniel, 
I have enjoyed reading your post. You mentioned, "Ideally, this can be seen as a limitation because when the Supreme Court interprets ambiguous constitutional statutes it intrinsically may not be interpreting the statute accordingly, which could cause significant deference to many individuals." As you noted, there are intrinsic difference enshrined in the idea of judicial review that the Constitution is constant, invariable and not amenable to revision of time-to-time enactment of congressional statute. This has a potential of incurring an interpretive conflict between the Supreme Court and Congress as a co-equal constitutional branch. This also could tacitly guide a new frame of constitutional adjudication in Germany and its following nations that established the independent constitutional court disintegrated from the normal supreme court. Nevertheless, the kind of dilemma still is not eradicated -who would be an ultimate authority to define or interpret the terms of congressional act. In this case and notably involving South Korea, the conflict would arise from the two highest courts. The Congress--National Assembly in Korea-would likely be an individual to be chaotic with conflicting interpretations. Such inter-branch resilience and any policy consequence over time would be inevitable with the democratic process to pursue the public ideals, and also seem interesting for the researchers in terms, "which interpretation would serve best with greater impact? Respectfully.

Author: daniel hallman Date: Tuesday, May 5, 2015 12:33:12 AM EDT Subject: RE: Discussion 1 - Week 10

\section{Daniel F. Hallman Jr., Discussion Post 1 Week 2.}

\section{Main Question Post.}

According to the Supreme Court of The United States (2015) "[t]he complex role of the Supreme Court in this system derives from its authority to invalidate legislation or executive actions which, in the Court's considered judgment, conflict with the Constitution" (para. 5). Additionally, "[t]his power of "judicial review" has given the Court a crucial responsibility in assuring individual rights, as well as in maintaining a "living Constitution" whose broad provisions are continually applied to complicated new situations" (Supreme Court of The United States, 2015, para. 5). Moreover, when determining strengths and limitations regarding Supreme Court policymaking by and through its interpreting ambiguous constitutional language can be an obfuscated question. Hamilton had posited that when establishing pertinent strengths of the Supreme Court when implementing policy concerning its interpretation of ambiguous constitutional language is that it pragmatically has the ability by and through judicial review to incorporate the "will of the people, as expressed in their Constitution, [which] would be supreme over the will of a legislature" (Supreme Court of The United States, 2015, para. 7).

Furthermore, Madison suggested that the Supreme Court has another pertinent strength, which is "that constitutional interpretation must be left to the reasoned judgment of independent judges, rather than to the tumult and conflict of political process" (Supreme Court of The United States, 2015, para. 7). E.g., the case known as District of Columbia v. Heller (2008) was a Second Amendment issue regarding the right to have a firearm (handgun) within the respondent's home without a license. This was largely due to his inability to procure the necessary licensing requirement and filed suit within the federal District Court for the District of Columbia (District of Columbia v. Heller, 2008, p. 576). Thus, the court held 
that the right to implement policy concerning the regulation of handguns within the aforementioned state is not entitled to do so when they "include the absolute prohibition of handguns held in use for self-defense in the home....some think that the Second Amendment is out modern...it is not the role of this Court to pronounce the Second Amendment extinct" (District of Columbia v. Heller, 2008, p. 636). Therefore, the two primary strengths of the Supreme Court is first, to establish the will of the people, by and through judicial review, and second, the right to do so through independent judges without political pressure as suggested by Hamilton (Supreme Court of The United States, 2015).

However, when positing the pertinent limitations of the Supreme Court that the first limitation is that "[t]he Justices must exercise considerable discretion in deciding which cases to hear, since more than 10,000 civil and criminal cases are filed in the Supreme Court each year from the various state and federal courts" (Supreme Court of The United States, 2015, para. 13). Therefore, this is a significant limitation because ideally the Supreme Court does not always have the ability to hear specific cases that they may wish and fundamentally has to do so on a pertinent hierarchy system. I.e., certain cases may be granted deference over others because of media, and or social pressure. The second limitation is that "[w]hen the Supreme Court rules on a constitutional issue, that judgment is virtually final...However, when the Court interprets a statute, new legislative action can be taken" (Supreme Court of The United States, 2015, para. 13). Ideally, this can be seen as a limitation because when the Supreme Court interprets ambiguous constitutional statutes it intrinsically may not be interpreting the statute accordingly, which could cause significant deference to many individuals.

This was quite evident when the Supreme Court determined what a qualified disability is pursuant to the ADA of 1990 within the case known as Toyota Motor Manufacturing, Kentucky, Inc. v. Williams, (2002). Fundamentally, what happened is that the ill-defined Toyota standard established within employment law as to what a qualified disability is pursuant to the ADA fundamentally missed the mark as to their interpretation regarding congressional intent. This led Congress to negate several Supreme Court rulings that did not properly define what a qualified disability is pursuant to the ADA by implementing amendments in 2009 . Therefore and as previously mentioned, that the Supreme Court is limited or can be limited when interpreting as to what they determine to be an ambiguous federal or constitutional statute regarding their pertinent definition or relevant holding, which completely misses the mark as to congressional intent; and has to be eradicated by and through Congress, which essentially can take years. Again, this was evident within the ADA of 1990 because it took Congress 19 years to eradicate the Supreme Court's ill-defined interpretation of the Act.

\section{Resources}

District of Columbia v. Heller, 76 U.S. 4631 (2008)

Supreme Court of The United States. (2015). The Court and Constitutional Interpretation Retrieved from, http://www.supremecourt.gov/about/constitutional.aspx

Toyota Motor Manufacturing, Kentucky, Inc. v. Williams, 534 U.S. 184 (2002) 
Great points about the flexibility of the Court to interpret the law and apply the norms of society in their decisions. This is one of the unique facets of the common law legal system. Our courts are guided by principles of justice and apply their interpretation to every decision, whereas civil law courts are more likely to follow rigid statutory law, leaving them far less flexibility in their application of that law.

KJF

Hello Prof.;

Thank you for the post. I do think that the Supreme Court is very cognitive to societal norms. That intrinsically, they will not always hear cases unless there is a salient issue to be addressed. E.g., I don't believe the Supreme Court would have heard a case regarding samesex marriage 25 years ago; however, because society is ready for the issue to be addressed the Supreme Court is fully aware that the issue is essentially ripe within society. Thanks again for the post.

- Daniel.

Hi. Annie,

I have enjoyed reading your post. The Eighth Amendment incorporated "cruel and unusual" in dealing with the state rights to punish. It is considered ambiguous since the common readers would be pluralistic in comprehending the notion and legal meaning of the phrase. Somebody may see that the ambit and scope amount to the kind of Titus Oates' punishment, say, being placed in pillory and being tied to a moving cart. Other view would even include the death penalty itself since the execution terminally ceases the existence of convicted criminals. The Amendment, as a provision of bill of rights, had been the kind of bottom-up declaration signifying the democratic revolution that gathered a knowledge and experiential conscience until the time of sanctification. The kind of medieval cruelty or tumult, e.g, witchhunt and burns death, as well as the exploitation of potent on excessive bail money or bonds had been triggered to be safeguarded. As T. Jefferson glorified with the First Amendment religious right -- why not the Oriental religion of many countries now that we got on the legitimate and more powerful state -- the background might even trace its justification on the Oriental cruelty on execution. Four arms and legs being tied to the vigorous cows and being placed into the big pot of melting water would reflect furious monarchs and their cruelty that would be sensed agonistic and immeasurable. The kind of execution had duly been protected, and the modern criminal theory of proportionality principle also had been inferred by the Supreme Court as a component of Amendment. Given the extensive use of amendment on mentally retarded and minor, it seems apparent that the living document philosophy would highly intervene. However, I do not suppose that the originalists would deny such expansion while the language is ambiguous susceptible of diverse interpretations and the crucial spirit is same against tyranny or arbitrary power. The originalists might not oppose more generous standard of state action theory including the large shopping mall or residential zoning areas since the liberators had been against such predicament. That seems more reinforced especially with the elicited guide of Jefferson, "the Constitution was designed to be an evolving document left to change and further interpretation." Nevertheless, the frame of originalist views can be more plausible with the characteristic of Constitution against the normal piece of statutes. That is not to say that I prefer the originalism philosophy, but the 
real question seems if the two camps could say that the word "copyright" in the provision of Constitution includes "trade secret" as literally incompatible. Have a good weekend!

Author: Annie Scott-Douglas Date: Friday, May 8, 2015 12:35:07 AM EDT Subject: RE: Discussion 2 - Week 10 (Scott-Douglas)

Judicial Philosophy and Establishment of Rights

The living document philosophy would best benefit law and public policy. The Court stated in Atkins v. Virginia (2002) that the Eight Amendment prohibits cruel and unusual punishment. The Constitution changes as evidenced by the amendments to the Constitution, and law and policy will change to meet evolving needs of society. According to Thomas Jefferson, the Constitution was designed to be an evolving document left to change and further interpretation. Supreme Court Justice Thurgood Marshall asserted that the Constitution must be interpreted in light of the moral, political, and cultural climate of interpretation (Marshall, 1987).

The United States Constitution was written in 1789 and has been amended twentyseven times (United States Constitution). The first ten amendments to the Constitution are the Bill of Rights that guarantees liberty and personal freedoms to Americans. One of the personal freedoms is guaranteed in the Eighth Amendment that forbids cruel and unusual punishment. In 1685, Titus Oates' punishment for perjury was to be placed in a pillory for two days and whipped one day while being tied to a moving cart.

In Atkins v. Virginia, (2002), Atkins and an accomplice abducted William Jones and killed him by shooting him eight times. Atkins was sentenced to death. However, during an appeal, it was determined that Atkins was mentally retarded that caused a shift in the Court's decision based wholly on the Eighth Amendment (Atkins v. Virginia, 2002). The Atkins ruling found that standards of decency had evolved to a point that nationally, people were against executing a mentally retarded person. The Court determined that the Eighth Amendment should be "interpreted in light of the evolving standards of decency that mark the progress of a maturing society (Vile, 2010). The Court determined in Atkins v. Virginia (2002) that the death penalty was regarded as cruel and unusual punishment for a mentally retarded individual. The Court cited Coker v. Georgia (1977) and Edmund v. Florida (1982). Both cases involved sentences that were considered excessive for the crimes and therefore, unconstitutional.

Although the States are left to define mental retardation, the Court is unable to clearly define "cruel and unusual punishment." In Graham v. Florida (2010), the Court ruled that life in prison without any chance of parole for a minor for any crime other than murder is cruel and unusual punishment. The Court shifted precedence in Miller v. Alabama and decided that minors cannot be sentenced to life without parole even for murder (Miller $v$. Alabama, 2012).

The Founders of the Constitution developed a document that contains ambiguous language in an effort that the document could be changed to meet the needs of an evolving society. However, as the political climate, societal trends and the environment changes, the Court will impose judicial philosophy to interpret the Constitution and shape the document to fit the needs of today's society. 
References:

Atkins v. Virginia, 536 U.S. 304 (2002),

Coker v. Georgia, 433 U.S. 584 (1977)

Edmund v. Florida, 458 U.S. 782 (1982)

Graham v. Florida, 560 U.S 48 (2010)

Miller v. Alabama, 2012, 567 U.S.

Vile, J. R. (2010). Essential Supreme Court decisions: summaries of leading cases in US constitutional law. Rowman \& Littlefield Publishers.

Hi. Precious,

I have enjoyed reading your post. You illustrated the Fifth Amendments and the court rules to expand and supplement with its constitutional meaning. One peer suggested that the kind of Miranda rule would be a practical type of amendment if the metaphor of justices actually and specifically reads the constitutional provisions. We have, nevertheless, twenty seven times amendment. Given the court role as such omnipotent, what do you think if later constitutional amendments have been prompted? Had it been intended to realize a uniform administration or prevent against the state dissidence, for example, assuming if the equal voting of woman would matter? Why do you think the equal protection of laws, say, the protection of Fourteenth amendment, would come short necessitating the new amendment on equal voting of woman? Have a good weekend!

Author: Precious Clayton Date: Friday, May 8, 2015 2:03:36 AM EDT Subject: RE: Discussion 2 - Week 10

Post an explanation of which judicial philosophy for constitutional interpretation (Originalism or Living Document) you believe would best benefit law and public policy. Then, describe a "right" which the Supreme Court established by interpreting the Constitution. Explain the constitutional interpretation that led to the establishment of this right.

A living Constitution is one that evolves, changes over time, and adapts to new circumstances, without being formally amended (Strauss, 2010). Meanwhile, the world has changed in incalculable ways. The nation has grown in territory and its population has multiplied several times over (Strauss, 2010). Technology has changed, the international situation has changed, the economy has changed, and social mores have changed, all in ways that no one could have foreseen when the Constitution was drafted (Strauss, 2010). And it is just not realistic to expect the cumbersome amendment process to keep up with these changes (Strauss, 2010).

The Constitution is supposed to be a rock-solid foundation, the embodiment of our most fundamental principles-that's the whole idea of having a constitution (Strauss, 2010). Other proponents of a living Constitution believe that the document was written with broad language that allows for a changing interpretation (Strauss, 2010). The Constitution stays 
living is through the amendment process. Over time, 27 amendments have been added to the Constitution. These include major changes like the prohibition of slavery and the enfranchisement of women (Strauss, 2010). The Constitutional amendment process is slow and difficult; it is meant to reflect only the greatest changes in public opinion, like the widespread belief in the early 20th century that women should be allowed to vote. The Constitution remains living in that its words can literally be changed over time(Strauss,2010).

The Fifth Amendment creates a number of rights relevant to both criminal and civil legal proceedings (LII, 2014). In criminal cases, the Fifth Amendment guarantees the right to a grand jury, forbids "double jeopardy," and protects against self-incrimination (LII, 2014). It also requires that "due process of law" be part of any proceeding that denies a citizen "life, liberty or property" and requires the government to compensate citizens when it takes private property for public use (LII, 2014). The Fifth Amendment protects criminal defendants from having to testify if they may incriminate themselves through the testimony (LII, 2014). A witness may "plead the Fifth" and not answer if the witness believes answering the question may be self-incriminatory. In the landmark Miranda v. Arizona ruling, the United States Supreme Court extended the Fifth Amendment protections to encompass any situation outside of the courtroom that involves the curtailment of personal freedom. 384 U.S. 436 (1966) (LII, 2014). Therefore, any time that law enforcement takes a suspect into custody, law enforcement must make the suspect aware of all rights (LII, 2014). Known as Miranda rights, these rights include the right to remain silent, the right to have an attorney present during questioning, and the right to have a government-appointed attorney if the suspect cannot afford one(LII,2014).

\section{Reference Page}

Legal Information Institute. (2014). Fifth Amendment. Retrieved from https://www.law.cornell.edu/wex/fifth_amendment

Strauss, D. (2010).The Living Constitution. Retrieved from

\section{Hi. Whitney,}

I have enjoyed reading your post. As the American Constitution Society illuminates, the practical aspect seems to underlie that both views would hold the original purpose to be ensured as feasible. As the originalism seeks original intent of framers to engraft with a case arising from the challenges different from the time when "a Population was smaller, ideals were different, social issues were of a different caliber." As one peer suggests that metaphor can fill the gap of ambiguous constitutional language and judges can even amend the Constitution as Justice Hughes boasted. This also corroborated with your view, "the living document ideology believe that the workings of the Founders were meant to set basic notions and fundamental principles by which to run the country." It seems also succinct to consider it eclectic "Jefferson sneered at the sanctimonious reverence which we hold this mere historic document, while Madison cautioned with some reverence for continuity...a nation could not have the "requisite stability." Given the pragmatism and realism viewpoint -- at this point, we are recalled that law is nothing but the statement of judges in the courtroom as Justice Holmes said -- the metaphor of judges and justices can enliven the old document newly refreshed, and the process of analyzing the precedents and prior cases on stare decisis rule could guarantee the feasible extent of requisite stability. Have a good weekend! 


\section{From Whitney: Judicial Philosophy and Establishment of Rights}

\section{Living Document}

The $8^{\text {th }}$ amendment to the Constitution reads that, "excessive bail shall not be required, nor excessive fines imposed, nor cruel and unusual punishments inflicted" (Cornell University Law School, 2015, I1). This amendment is generally referenced when considering the death penalty, as was seen in reading this week's case, Atkins $v$ Virginia (2002). When his intelligence was questioned by a psychologist, Atkins' - who had twice been convicted of abduction, robbery, and murder... and sentenced to death - case was taken to the Supreme Court to question the constitutionality of sentencing a mentally impeded person to death (Oyez, 2015). In a 6-3 opinion, the Court ruled that such an action did constitute a 'cruel and unusual punishment' since Atkins was deemed mentally incapable. The punishment was considered excessive when applying the evolving standards of the nation and the law (Atkins v. Virginia, 2002). The freedom established in this case is therefore that to life - regardless of the crime - when considering mental retardation.

Two schools of thought exist when considering the interpretation of Constitutional writings - originalism and living document. Proponents of an approach to Constitutional interpretation that allows for the strict adherence to Founders' words are those who believe in originalism. Seeing the Constitution as more of a living, evolving document, proponents of the living document ideology believe that the workings of the Founders were meant to set basic notions and fundamental principles by which to run the country. In their ruling in Atkins v. Virginia (2002), the living document philosophy was adopted by the majority of Supreme Court Justices.

Interpreting the Constitution utilizing the 'originalism' vs. 'living document' philosophy is, in my opinion, highly dependent on the issue at hand. There will certainly be instances in which strict adherence to the document will be more appropriate than a more modern-day interpretation. When the Constitution was drafted, the United States - and the individuals who wrote the document - were in a completely different time. Population was smaller, ideals were different, social issues were of a different caliber. Surely, the Founders understood that, as the country grew and expanded, their fundamental ideologies would need to be altered. With this in mind, I think that a 'living document' philosophy to Constitutional interpretation is more fitting to law and public policy. The fundamental Constitutional constraints as presented by the Founders can never be dismissed, only amended with ample support. But to follow too closely some of the exact wording as presented in the Constitution, in present day, would potentially result in the decline of rights to citizens. The document needs to be adhered to, but modernized to fit the needs of the country in the present. "What accounts for our enduring faith in the Constitution is not that we have rigidly adhered to original understandings frozen in amber or to so-called strict construction of the text. It is that we have continually interpreted the Constitution's language and applied its principles in ways that are faithful to its original purposes and to the social context in which new challenges arise (American Constitution Society, n.d., pg 44). 


\title{
[Week 11]
}

\author{
Hi. Tracee
}

Thank you for the question. I think your point is highly pertinent since a Good man on legal research Trace well to the research purpose ${ }^{\wedge} \wedge$. The FCC policies, in principle, had been based on the net neutrality and liberal market which officially confirmed around 2004-5. They were substantiated by being added with the kind of terms and restrictions, such as "according to the law," "subject to regulation" and words of moderation. It means the initial principle had turned with a due regulation and to the interest of public. Actually the liberal market and net neutrality, despite its best efficiency, would not be plenary in the face of variety of public interests, such as consumers group and small enterprises. It may lead to merger which could possibly manipulate the market, even though the consumers may benefit a cheap service with bigger Google. Yesterday, the kind of issue arose in the National Assembly of Korea if the major telecommunication services can no longer reap the revenue of subscription fee for the provision of their service. The possible Act on resolution means the lower expense of mobile users and increase of public duty for the telecom services. The speed of internet or fast lane also would be an interest of consumers that can be affected by the FCC policies and Court rules. Moreover, the equal opportunity of freedom of expression may be argued in the future that the technological advances can bring a new deal of law against various challenges. Nevertheless, the policies of FCC seem to centralize thus far, which was vindicated over the ten years of experience from 2004 through the current. Since the Brand X decision in 2005, no major disputes had been exchanged in the court proceeding except for the two Circuit Court cases of District of Columbia. It rejected the power of FCC to sanction, but other than classification issue. Given the classification issue is more professional or technological, the 2005 Chevron rule may still govern? Meanwhile, the FCC led by Martin had deeply engaged with many announcements and public relationships with popular exposure over the period of time. Have a good weekend.

\section{TRACEE GOODMAN}

RE: Discussion - Week 11

In searching for a case for analysis for this assignment, I found that there were several cases involving the FCC, in your researching this assignment or for any other reason, have you ever read any of the FCC's policies? Do you find them to be ambiguous? If an Agency's policies are old or because of the changes in technology, which would impact an agency such as the FCC, should they be required to review and amend their policies without judicial review?

\section{Hi. Daniel,}

I have enjoyed reading your post. I am interested that the tariff classification is not only a matter of national laws, but also international laws. The world harmonized system of product is essential to the trade administration and expected to be fairly administered. The domestic measure subject to the review of WTO dispute body is viewed so comprehensive as to include judicial decisions besides the acts or regulations. How do you find the ruling to be congruent with the international trade laws? This question is because the trade administration would well know the WTO laws while the Court may be gained of congressional act or Constitution. You stated citing Graham et al, the Chevron rule tends to be limited in trend. 
How do you reconcile this trend with the technological advances and increased workload of Courts? Have a good weekend.

Author: daniel hallman Date: Wednesday, May 13, 2015 12:05:11 AM EDT Subject: RE: Discussion - Week 11

\section{Daniel F. Hallman Jr., Discussion Post Week 11.}

\section{Main Question Post.}

The case selected for this week's discussion is the case known as United States $v$. Mead Corp., (2001). Additionally, the aforementioned case did not apply the Chevron deference. As established by the Supreme Court that the Chevron U.S.A., Inc. v. Natural Resources Defense Council, Inc., (1984) case fundamentally established how administrative agencies promulgate congressional intent when establishing rules and regulations (Graham \& Kaluza, 2014, p. 26). Furthermore, the United States Supreme Court within the Chevron case elucidated, "[w]hen a court reviews an agencies construction of the statute which it administers, it is confronted with to questions. First, always, is the question whether Congress has directly spoken to the precise question at issue" (Chevron U.S.A., Inc. v. Natural Resources Defense Council, Inc., 1984, p. 842). Subsequently, "if the intent of Congress is clear, that is the end of the matter...the agency, must give effect to the unambiguously expressed intent of Congress" (Chevron U.S.A., Inc. v. Natural Resources Defense Council, Inc., 1984, pp. 842 - 843). However, the Supreme Court also enunciated within the Chevron U.S.A., Inc. v. Natural Resources Defense Council, Inc., (1984) case that if the court posits that if Congress did not deal with the issue at hand it should establish whether the "statute is silent or ambiguous with respect to the specific issue, the question for the court is whether the agencies answer is based on a permissible construction of the statute" (Chevron U.S.A., Inc. v. Natural Resources Defense Council, Inc., 1984, p. 843). Therefore, if Congress within an Act leaves gaps the administrative agency should adequately regulate unless they are capricious in nature or in direct opposition of the statute (Chevron U.S.A., Inc. v. Natural Resources Defense Council, Inc., 1984).

Furthermore, and as aforementioned the case known as United States v. Mead Corp., (2001) did not adhere to the Chevron deference. Additionally, the primary question within the aforementioned case that the Supreme Court would ultimately address "is whether a tariff classification ruling by the United States Customs Service deserves judicial deference. Hence, the Supreme Court ultimately indicated "[w]e agree that a tariff classification has no claim to judicial deference under Chevron, there being no indication that Congress intended such a ruling to carry the force of law" (United States v. Mead Corp., 2001, p. 221). According to Graham and Kaluza (2014) that the United States v. Mead Corp., (2001) established "that an agencies interpretation receives Chevron deference only if the 'agency interpretation claiming deference was promulgated in the exercise' of its rulemaking authority" (p. 26). I.e., "courts must defer to agencies only when an agencies statutory interpretation arose agencies interpretation de novo and that interpretation is merely accorded 'weight' under Skidmore v. Swift \& Co., 323 U.S. 134 (1944)" (Graham \& Kaluza, 2014, p. 26). That vis-à-vis administrative weight concerning administrative interpretation is heavily dependent on the validity and prudent reasoning, as well as its primary power of persuasion (Graham \& Kaluza, 2014). 
What is significant in relation to the Skidmore v. Swift \& Co., (1944) case is that the Chevron (1984) case did not negate the Skidmore (1944) holding. Therefore, the Supreme Court utilized the Skidmore holding that established "an agencies interpretation may merit some deference whatever its form, given the 'specialized experience and broader investigations and information' available to the agency" (Skidmore v. Swift \& Co., 1944, p. 139; as cited within Chevron U.S.A., Inc. v. Natural Resources Defense Council, Inc., 1984, p. 234). The Supreme Court also expressed that "judicial responses to administrative action must continue to differentiate between Chevron and Skidmore, and that continued recognition of Skidmore is necessary for just the reasons Justice Jackson gave when the case was decided" (United States v. Mead Corp., 2001, p. 238). Therefore, and as posited by Graham and Kaluza, (2014) that 30 years have conceded since the Chevron (1984) case, which remains primary authority within case law, that courts have consistently limited agency deference since the Chevron inception.

Resources

Chevron U.S.A., Inc. v. Natural Resources Defense Council, Inc., 467 U.S. 837 (1984)

Graham, D.P, and Kaluza, K. (2014). Redrawing Chevron Deference. The Metropolitan Corporate Counsel, July/August. Retrieved from, http://www.metrocorpcounsel.com/articles/29260/redrawing-chevron-deference

Skidmore v. Swift \& Co., 323 U.S. 134 (1944)

United States v. Mead Corp., 533 U.S. 218 (2001).

Hi. Tina,

Thank you for the good post. Tobacco product is enjoyed nationally in Korea, and the price increase by the Government this year shocked the smokers. Tobacco industry is nationally owned by the special enterprise of Government in Korea. Do you see if there is any chance that the tobacco and cigarette are nationalized in the US? Have a good weekend.

\section{Supreme Court Rulings and Administrative Agencies}

\section{FDA v. Brown}

The FDA wanted jurisdiction over the regulation of tobacco products. The Supreme Court applied part one of the Chevron deference two-part test and determined that the Federal Food, Drug and Cosmetic Act was not ambiguous and Congress intended to exclude tobacco products from the FDA's jurisdiction. Through the application of part two, the Court did not defer to the agency's interpretation of the statute. The Court affirmed Congress had not granted the FDA jurisdiction to regulate tobacco products. The result of the Court's ruling is that the FDA cannot assert jurisdiction to regulate tobacco products. The FDA's argument is that nicotine is a drug; tobacco is a device for administering the drug; therefore, tobacco is to be regulated by the FDA. The Courts ruled that Congress clearly did not intend to include tobacco under FDA authority. Congress' intent has been expressed through tobacco-specific legislation that prohibit the FDA from imposing any regulations on tobacco. 
References

Chevron U.S.A. v. Natural Resources Defense Council 467 U.S. 837 (1984) Food and Drug Administration v. Brown 529 U.S. 120 (2000) 
